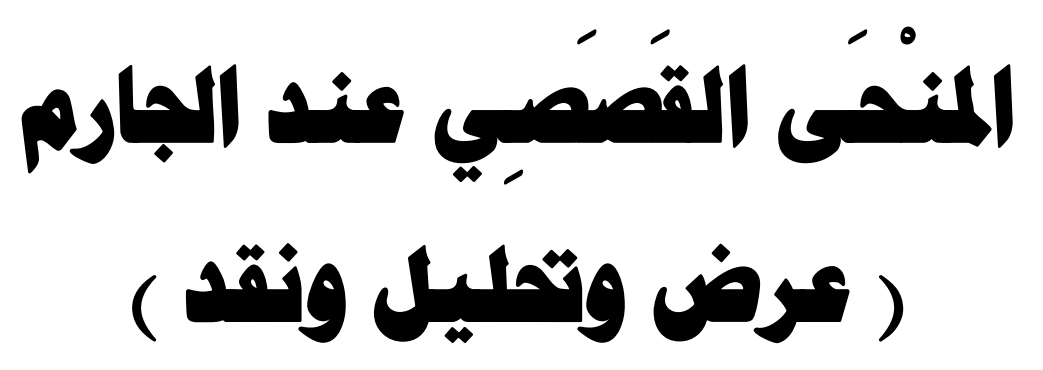

الدكتهر / علي مصمد علي إسماعيل ندا

أستاذ الأدب والنقد المساعد والئ

جامعة الأزهر

كلية اللغة العربية بالمنصورة 
$-\mu \cdot \Lambda \Lambda$. 


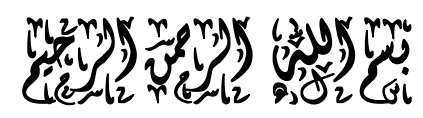

مُ010

الحمد لله رب العالمين ، و الصلاة و السلام على سيدنا محمد ، وعلـى

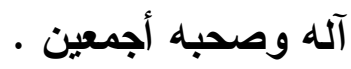

\section{أما بعد}

فقد حفل العصر العديث بأدباء أفذاذ ، أفاض البـاحثون فـــي دراســة

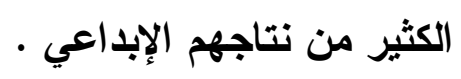

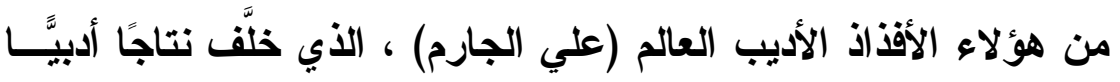

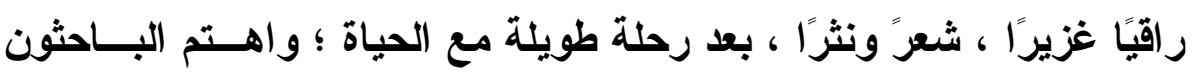

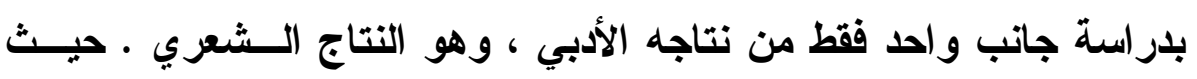

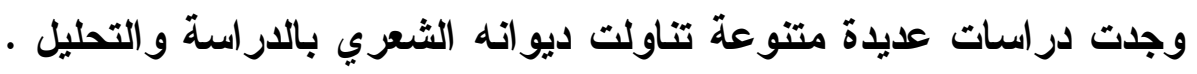

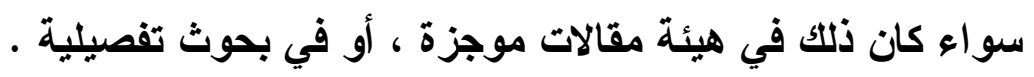

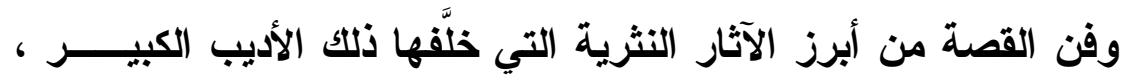

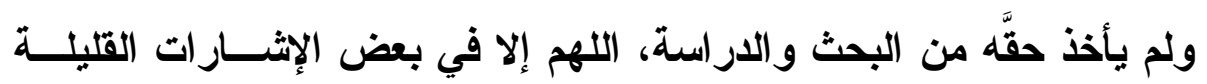

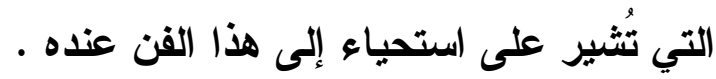

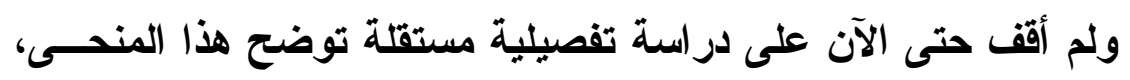
وتبرزه في ثوب يتناسب مع أهميتها ، وقيمتها الفنية .

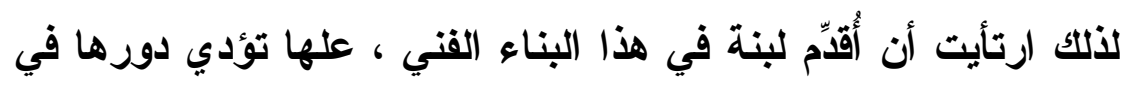

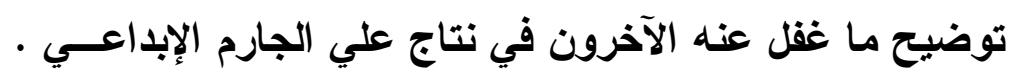

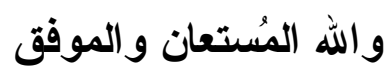




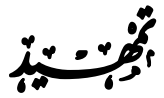 \\ إطلالة على هياة البارم ونشأته.}

هو علي محمد صالح عبد الفتاح إبر اهيم محمد الجارم ـ ينتـسب مسن فئن

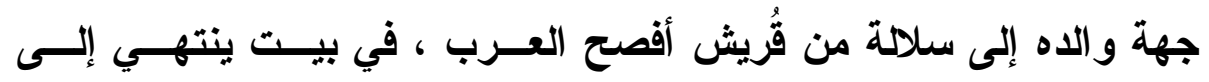

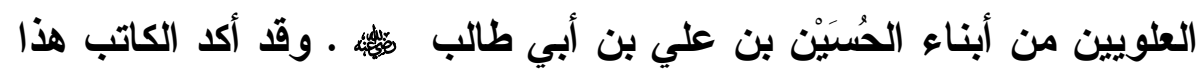

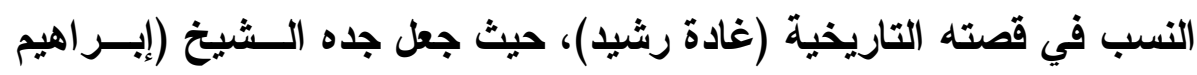

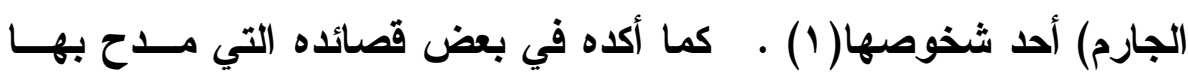
رسول الله

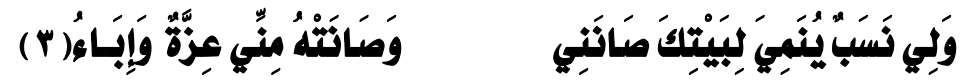

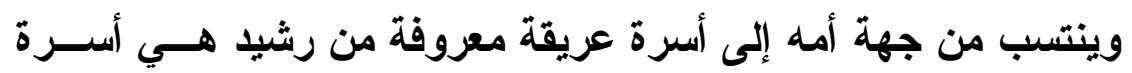

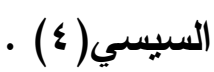

فالجارم ينتسب إلى أسرة عريقة لها جذور عربية راسخة فـي رشـيـ

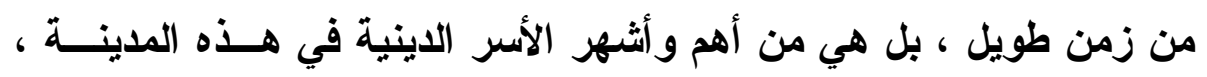

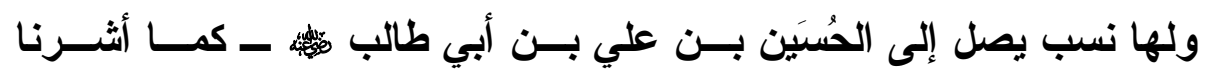

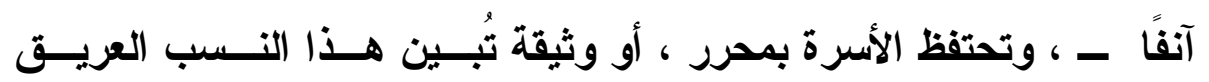

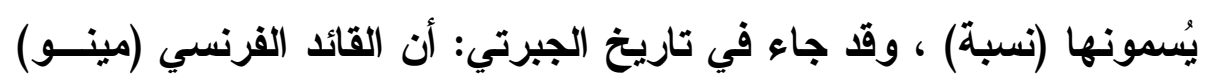

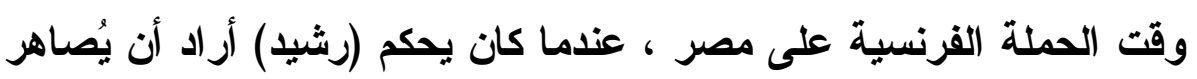

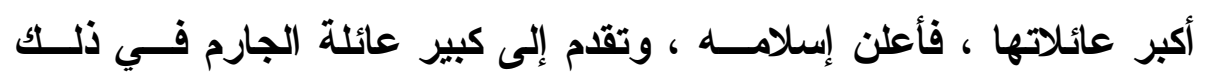

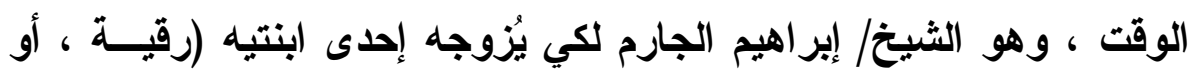

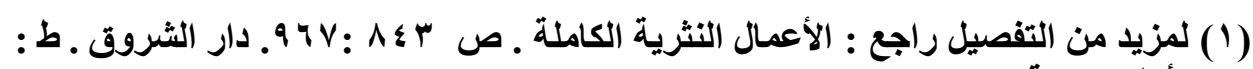

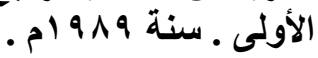

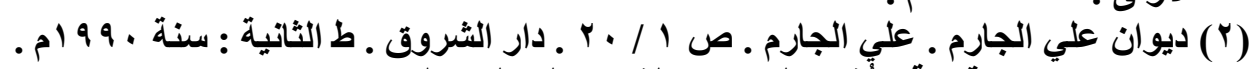

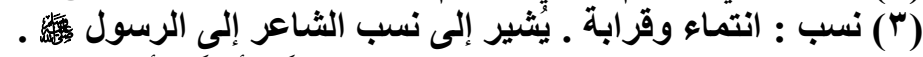

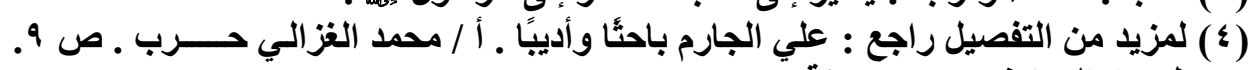

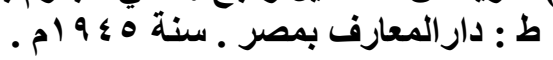
$-r \cdot q \cdot-$ 


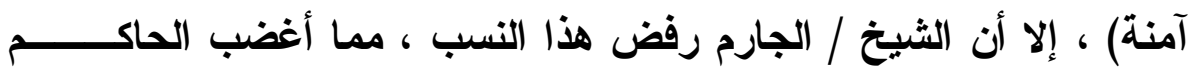

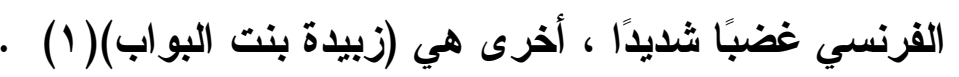

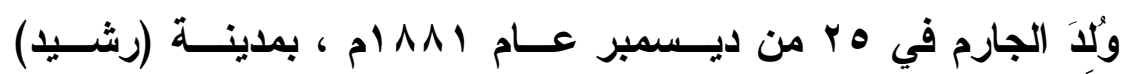

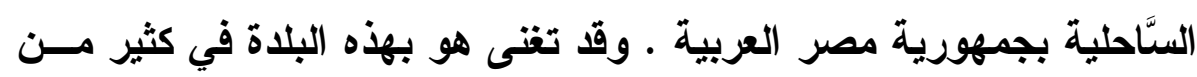

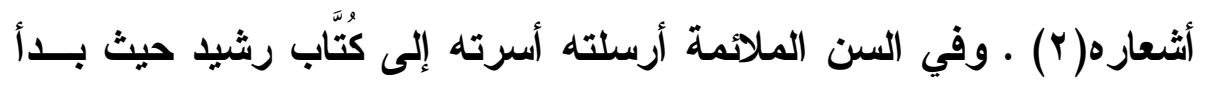

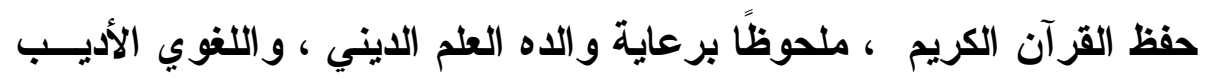

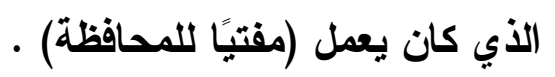

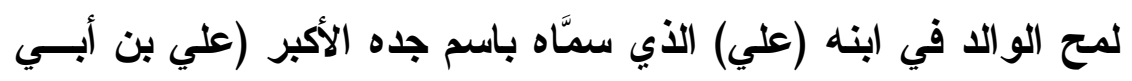

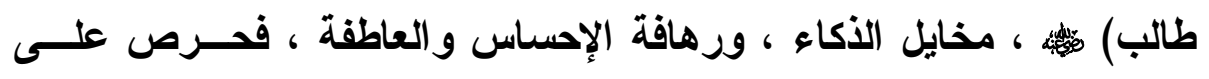
تنمية كل ذلك بالتشجيع و الار اسة و التذكرة .

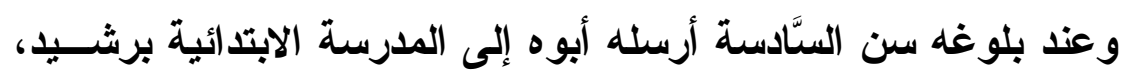

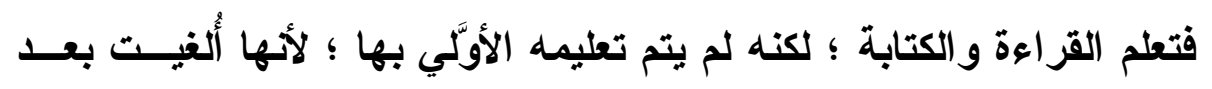

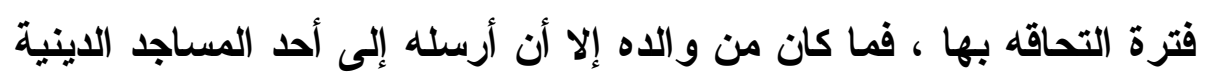

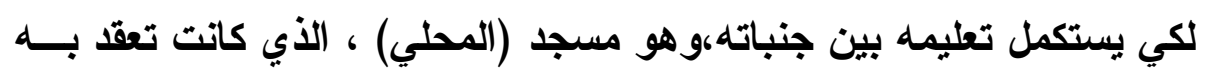

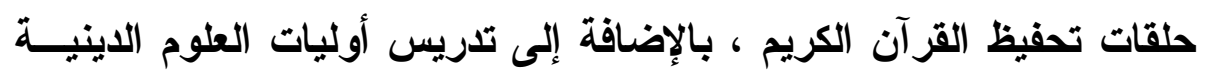
و اللغوية ..

وبالفعل يو اظب الصبي الصغير على حفظ كتاب الله بحب كبير ، ويُتابع

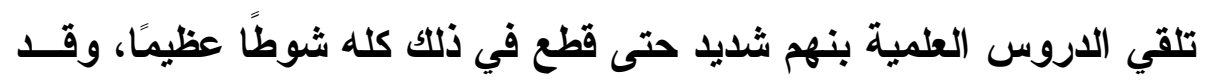

(1) لمزيد من الإيضاح راجع : علي الجارم ـ باحثًا وأدييًا ـ أ / محمد الغزالي حرب ـ ص

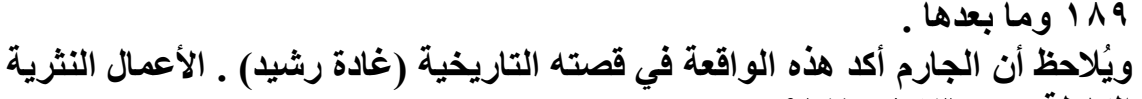

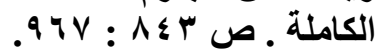

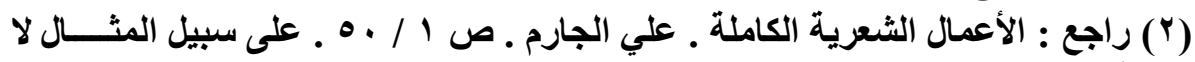
الإنصر 
صادف هذا التفوق الكبير في التحصيل ، و النبوغ العظيم في التلقي هــوَى

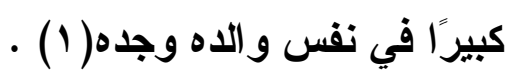

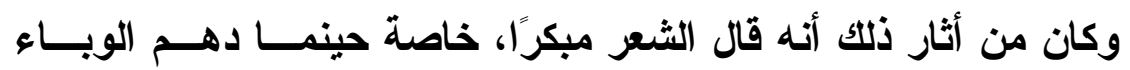

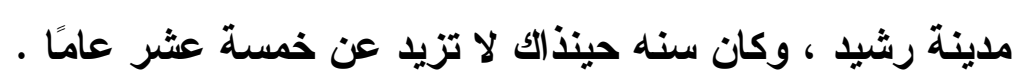

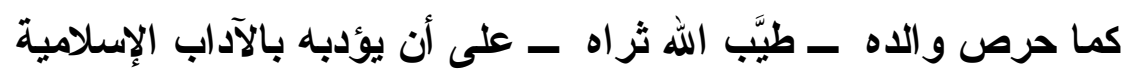

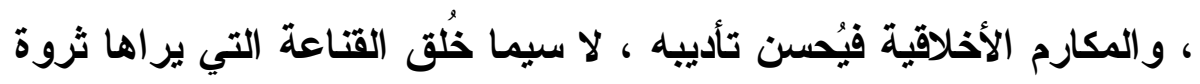

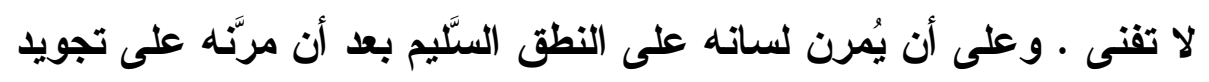

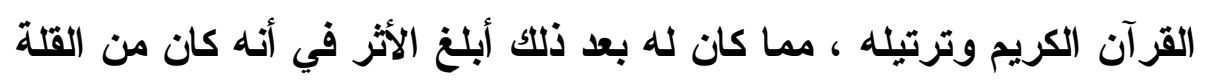

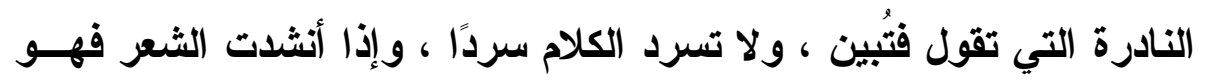

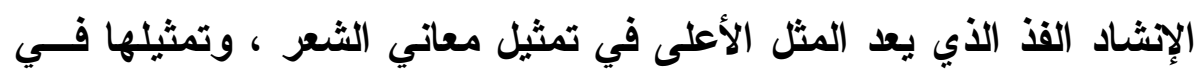

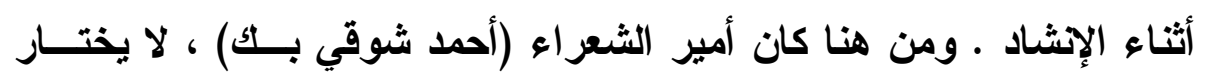

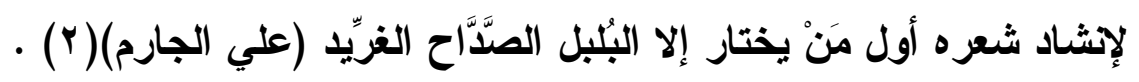

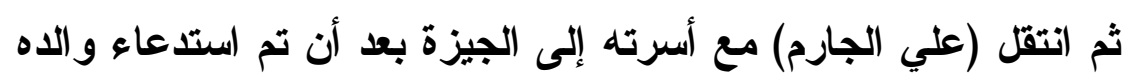

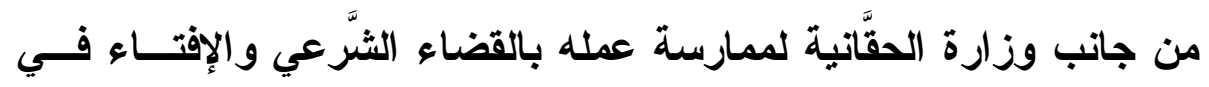

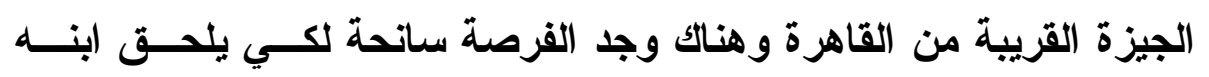

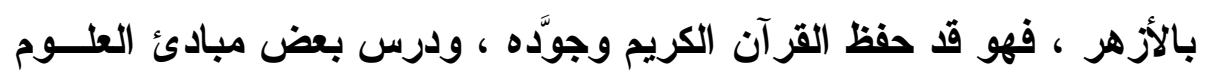

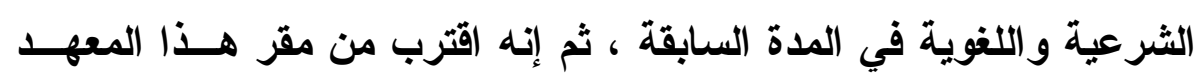

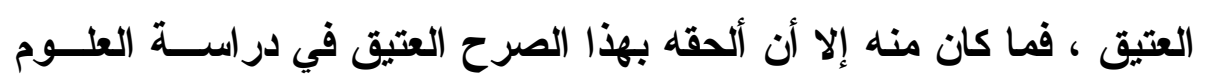

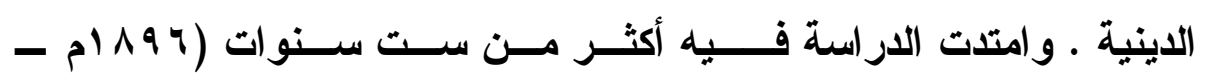

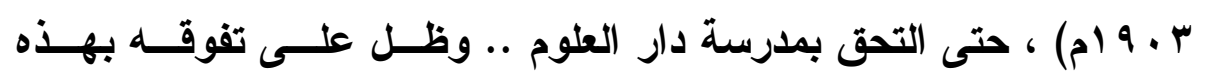

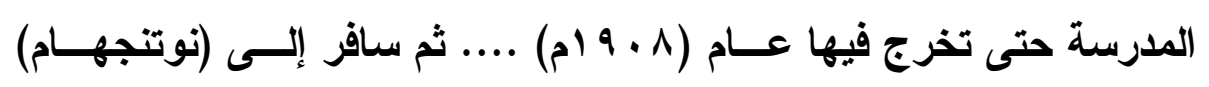

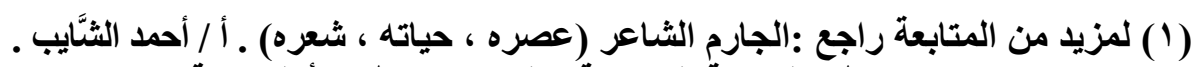

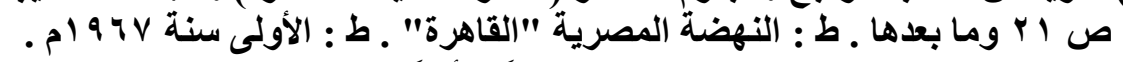

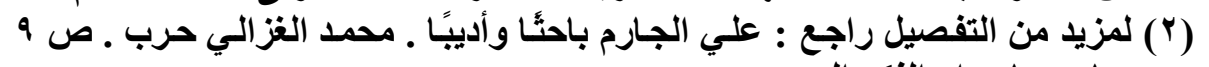




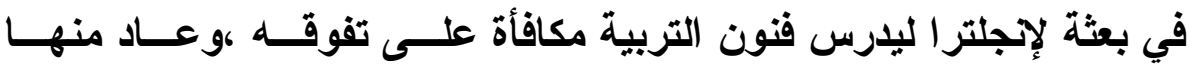

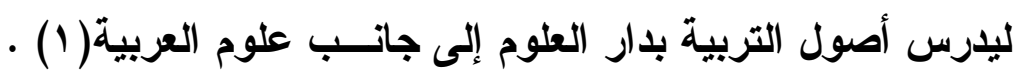

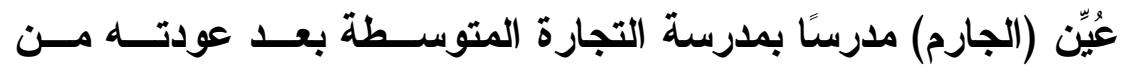

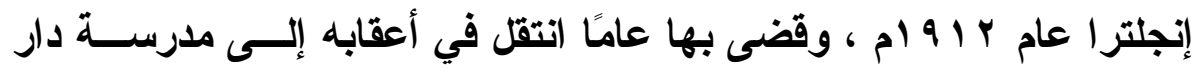

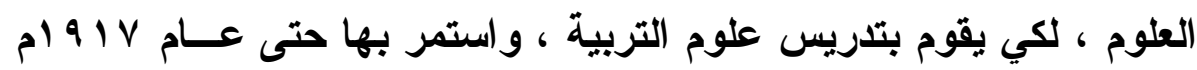

وفي مايو MIV ام نقل (الجارم) من التدريس بار العلوم إلى التفتيش

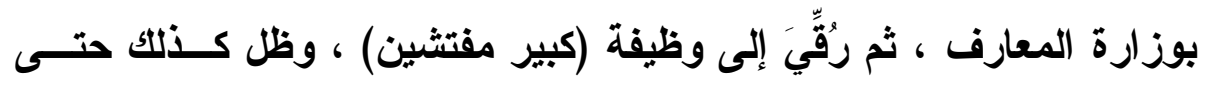

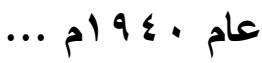
وفي أثناء عمل (علي الجارم) بالتفتيش أُسند إليه الإثراف على مجلة

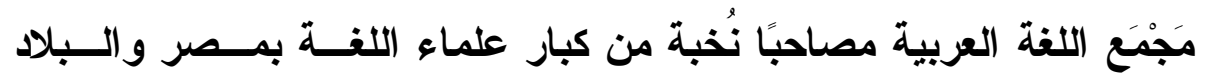
العربية والأُوربية وقتئذ(ب) ل.......

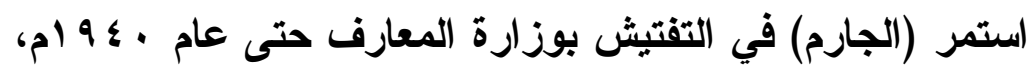

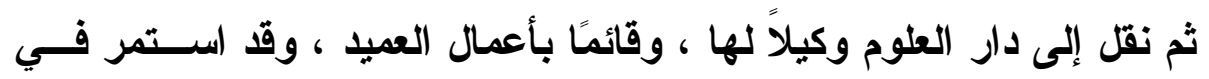

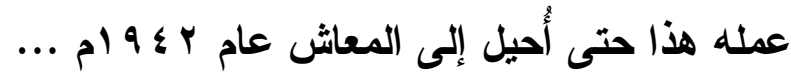

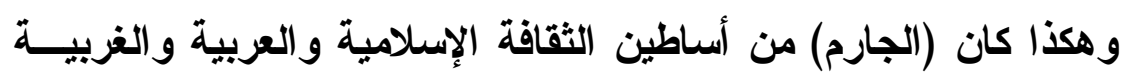

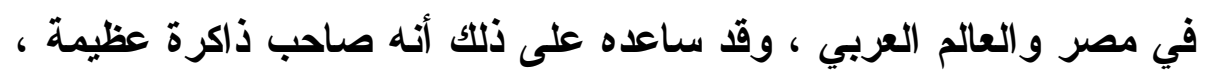

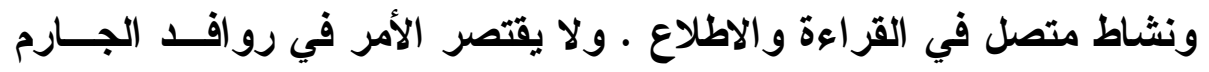

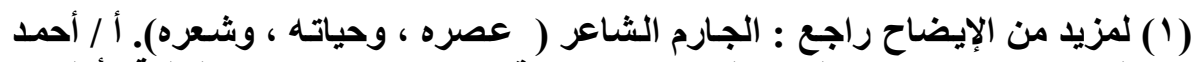

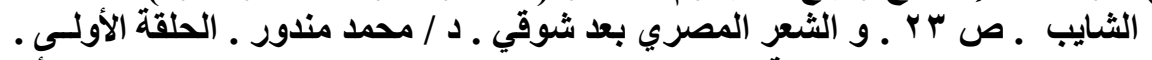

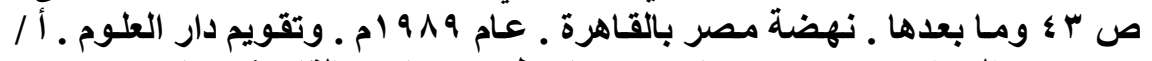

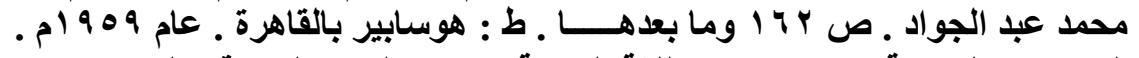

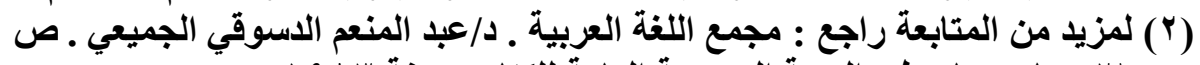

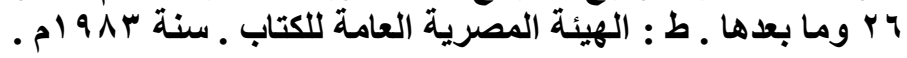
$-r \cdot 9 r$. 


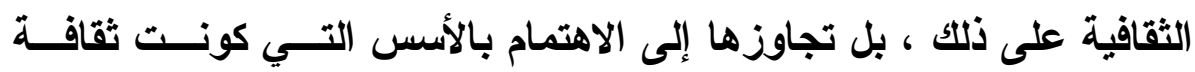

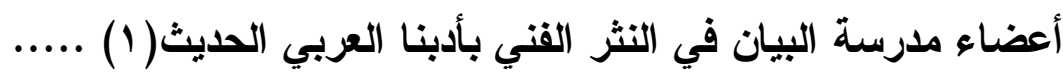

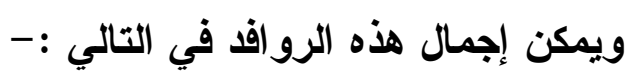

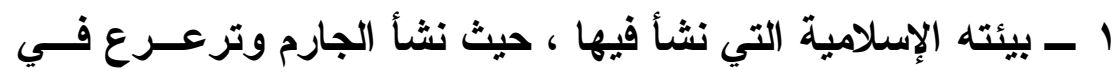

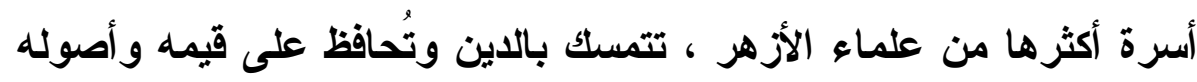

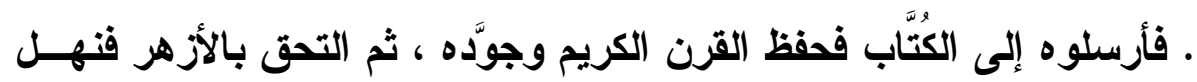
من علومه العربية والإسلامية على يد شيوخه و وعلمائه .

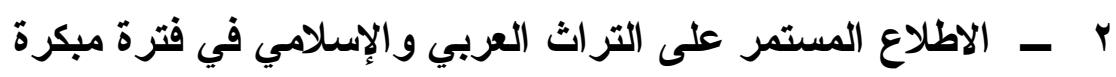

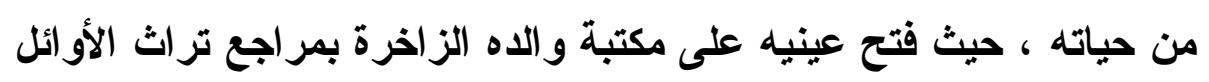

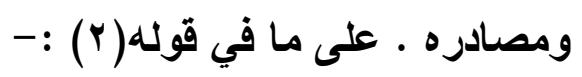

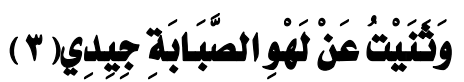

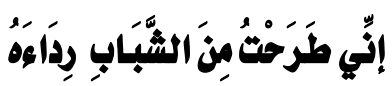

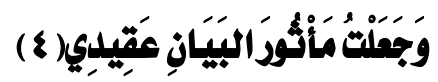

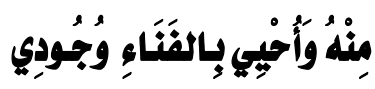

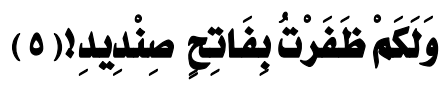

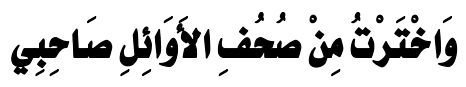

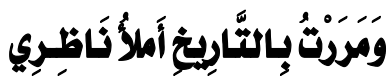

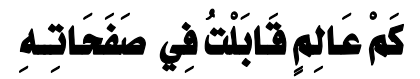

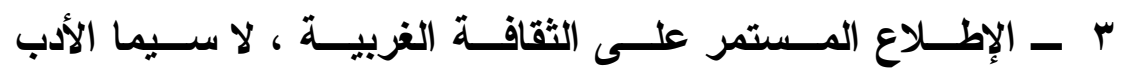

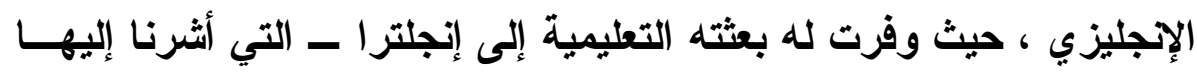

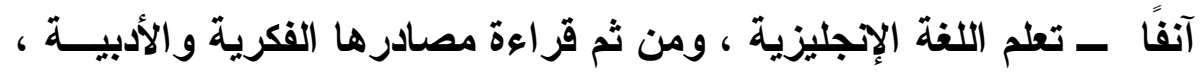

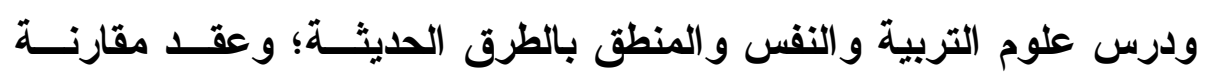
علمية بينها وبين الحضارة العربية والإسلامية .

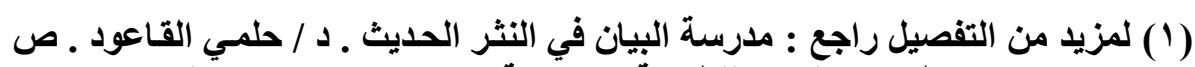

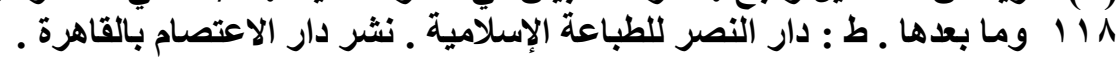

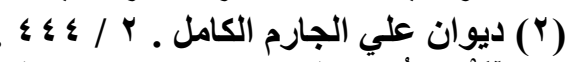
الصَّبَابَة : رقة الثوق وحرارتهه . 


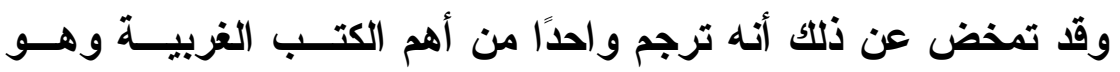

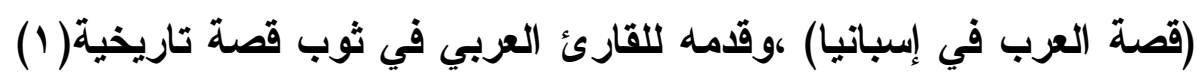
ـ ـ على ما سيأتي بإذن الله تعالى.

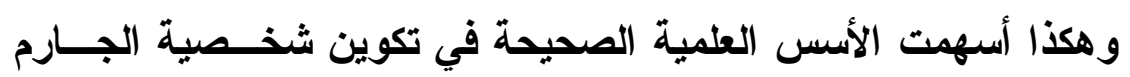

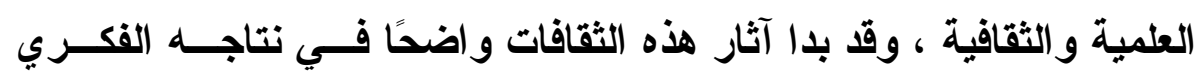

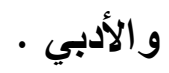

\section{أها عن نتاجه العلمي الفكري فهو يتمثل في الآتي :-}

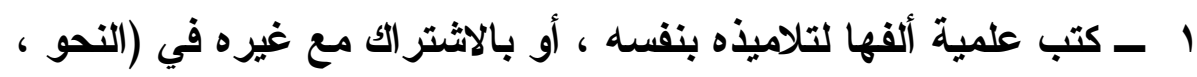

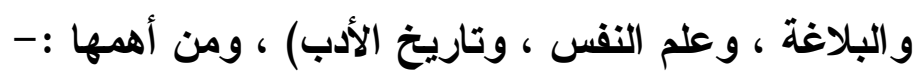

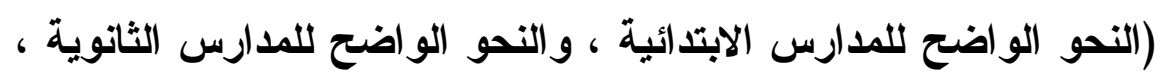

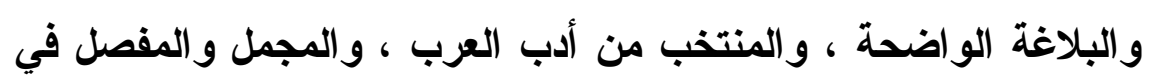

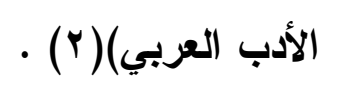

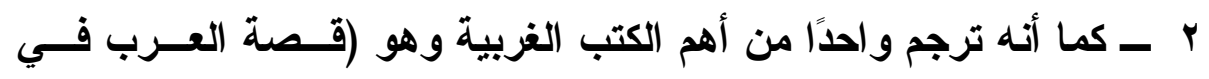

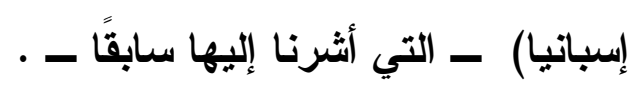

r ـ مقيق علمي دقيق لبعض كتب التراث بالاشتر الك مع بعض الأسـاتذة

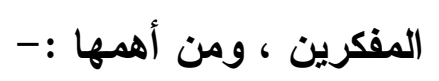

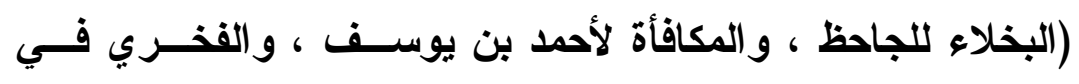

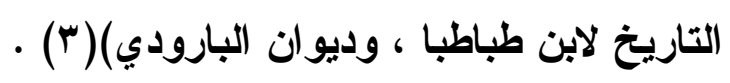

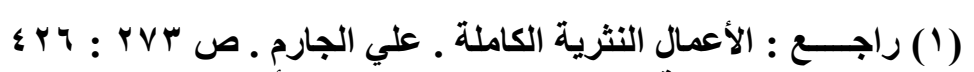

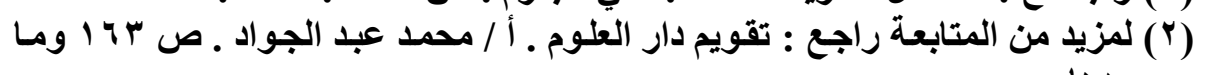
بعدها من من المن

(r) لمزيد من التفصيل راجع : الجارم الثاعر (عصره ، وحياته ، وشعره) ـ ص به ومـا

$$
-r \cdot 90-
$$




\section{وأها عن نتاجه الأدبي فهو يتمثل في الآتي :-

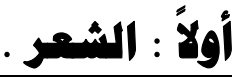

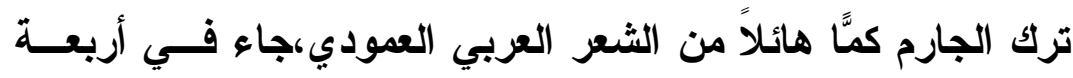

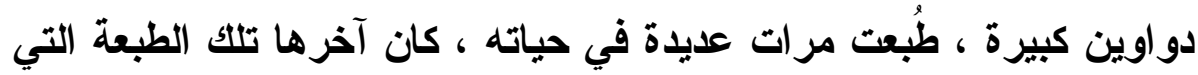

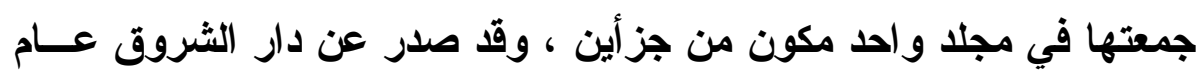

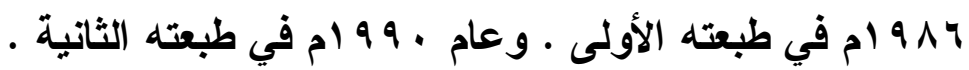

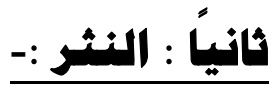

اهتم أديبنا الكبير بالنثر الأدبي في شقيه (القصة ، والمقال) ـ حيث كانت له إبداعات فنية جمَّة في هذين الفنيين .

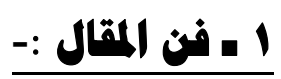

كان للجارم باع كبير في مجال فن المقال حيث امـتلأت الــصف

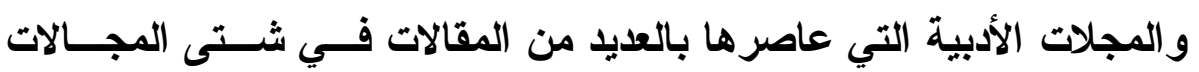

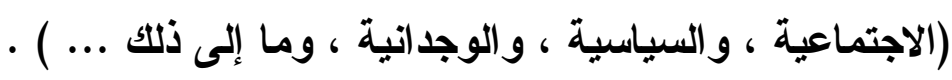

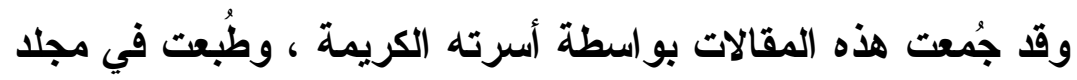
واحد نشرته دار الثروق عام 999 ام ؛تحت عنوان (جارميات) .

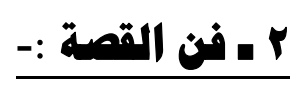

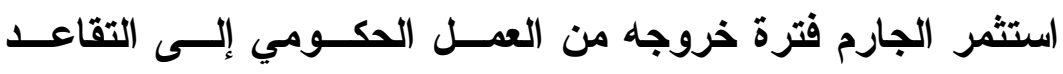

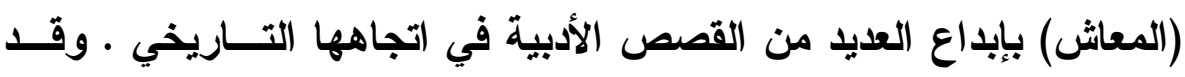

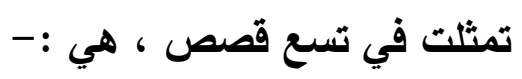

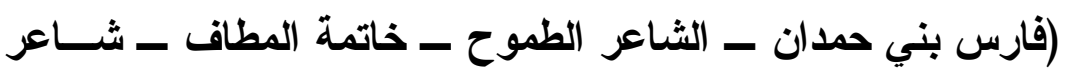
ملك ـ هاتف من الأندلس ـ الفارس الملثم ـ مرح الوليد ـ سيدة القصور

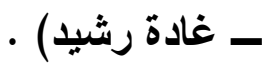


وقد طُبعت هذه القصص مرات عديدة ، كان آخرها تلكك الطبعـــة

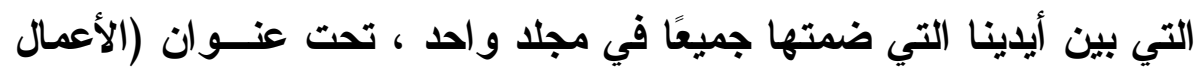

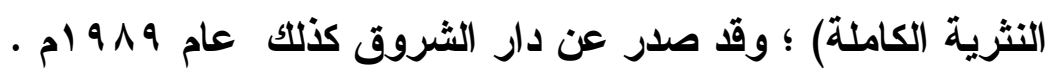

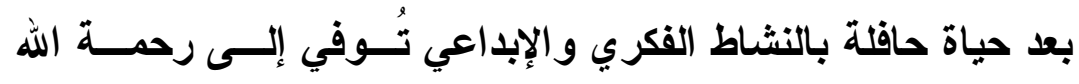

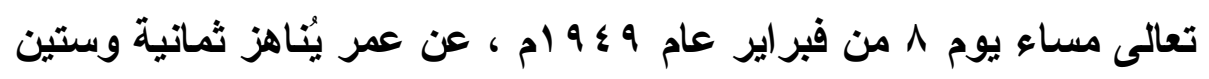

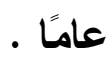

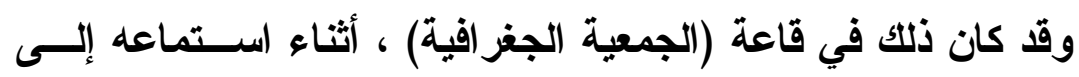

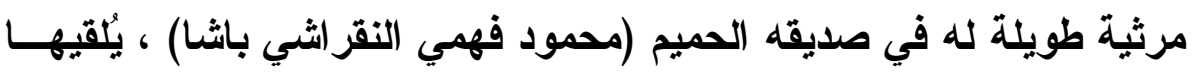

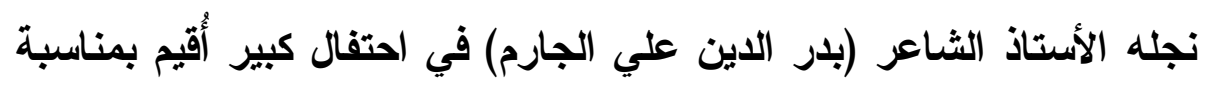

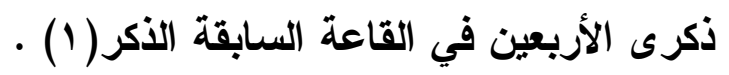

\section{*** $* * * * * * * * *$ \\ القسم الأول \\ عرض الأحداث والأفكار}

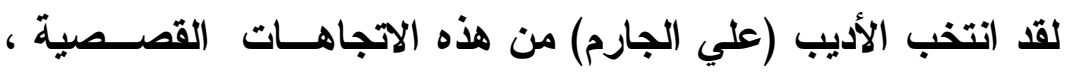

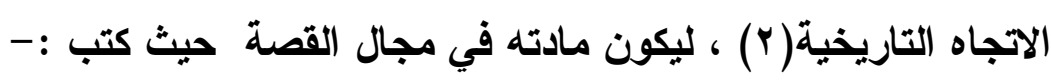

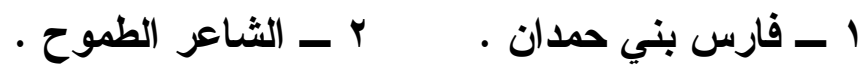

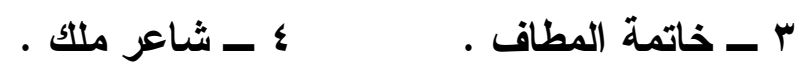

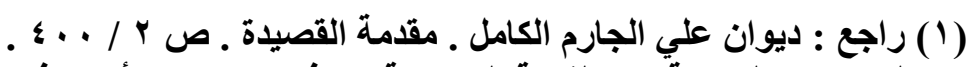

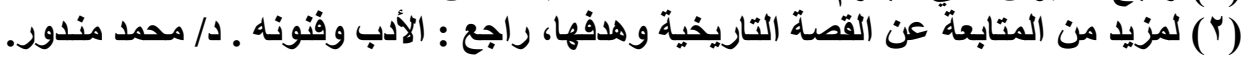

نهضة مصر بالقـاهرة ـ واتجاهـات وأراء في النقد الحـيث ـ دـ / محمد نايـل ـ مطبعـة

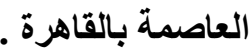
سنة 9 ام ام ـ و الرواية التاريخية في الأدب العربي الحديث .د / أحمد الهواري ، د / قاسم

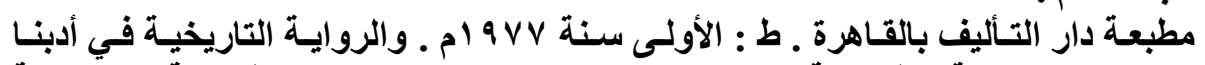

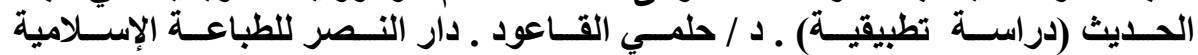

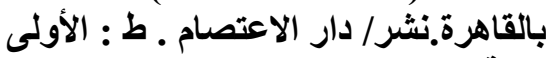




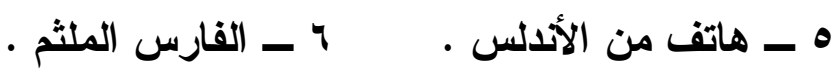

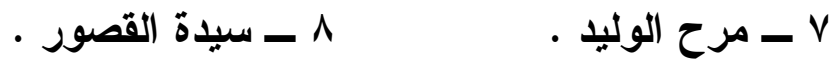

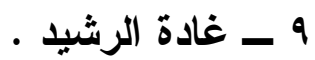

فالقصة عند الجارم جميعها مستمدة من التاريخ العربي بعد ظهـور الإسلام بلاءًا من العصر الأموي،حيث استقى منه أحداث قصة (مرح الوليد)

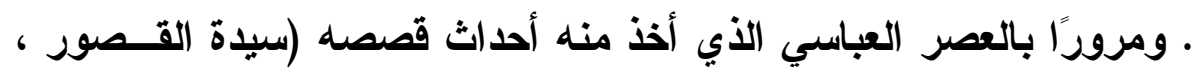
وفارس بني حمدان ، والثاعر الطموح ، وخاتمة المطاف ) ـ ثـــم العـصر

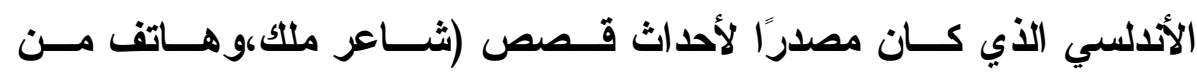

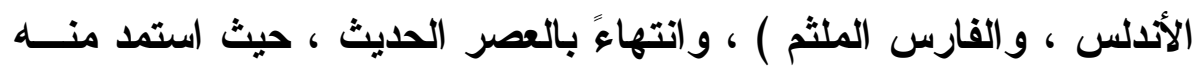

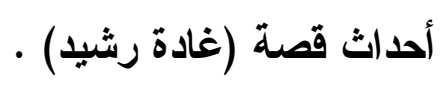
منطلقًا في ذلك من أن التاريخ العربي علــى امتـــداد حقبـــه كــان

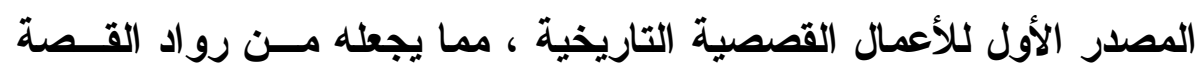
التاريخية العربية ذات الاتجاه الإشثائي( (1) . ولعل الباعث الأي دفع الجارم إلى هذا المضمار دون غيره يتجسـد

$$
\text { في المحاور الآتية : -- }
$$

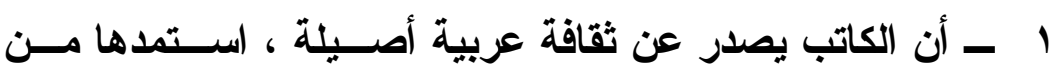

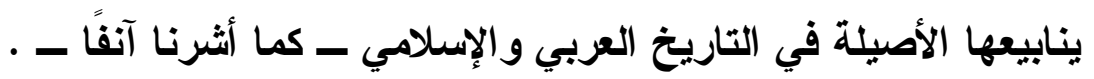
r المجيا ، وقمه في لون قصصي إلى مواطنيه ، وبخاصة النَّ هء و الثباب ،

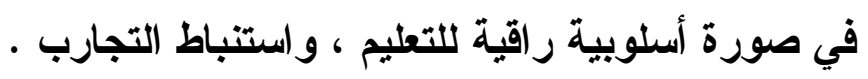
فالتاريخ العربي والإسلامي نبع فيَّاض للقصص التي تقـوم علــى

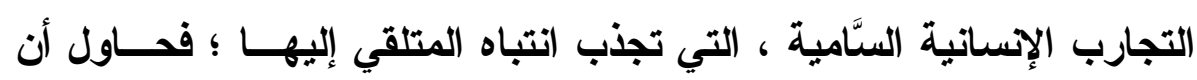

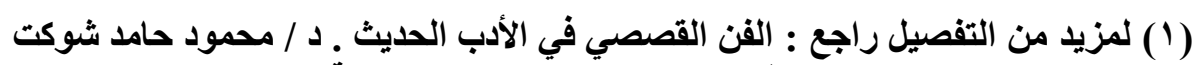

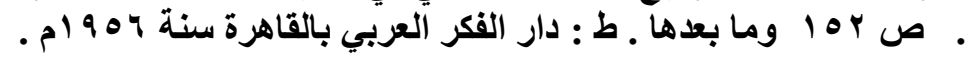


يُقدام شيئًا منها بأسلوب عربي رصين إلى أبناء أُمته لإيجـاد الـصلة بـين الماضي و الحاضر ، و العمل على تجديد التراث المجيد .

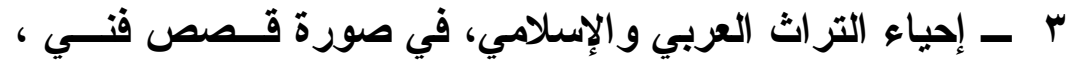

$$
\text { وتقديمه في هيئة حديثة . }
$$

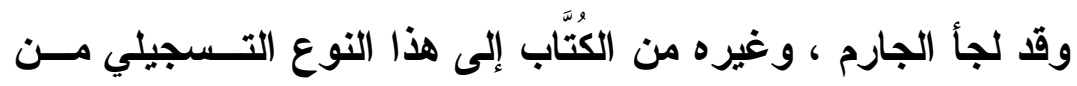

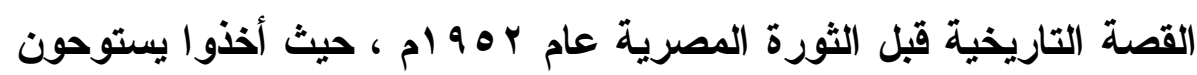

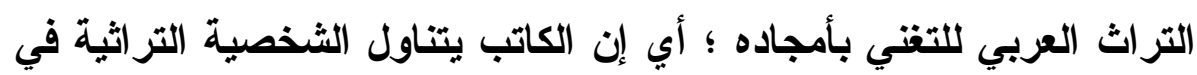

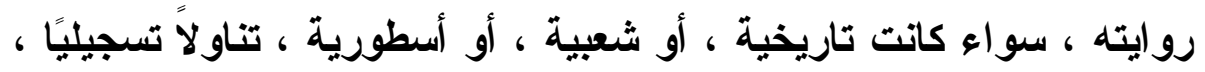

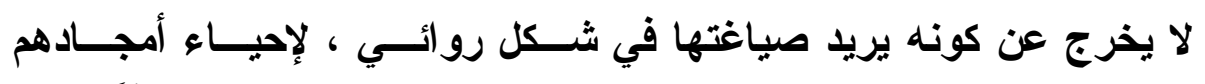

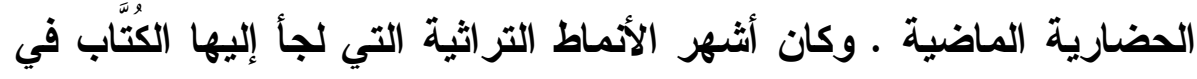

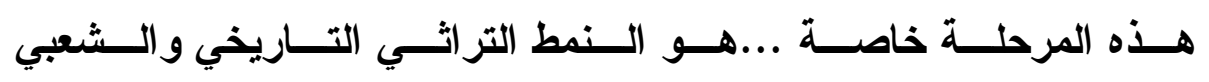

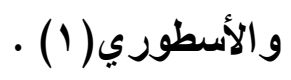

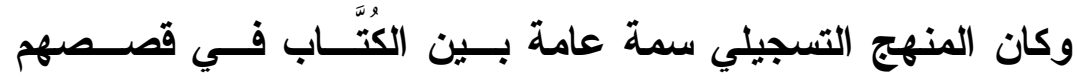

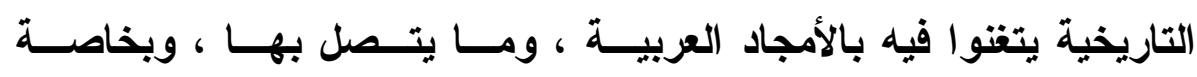

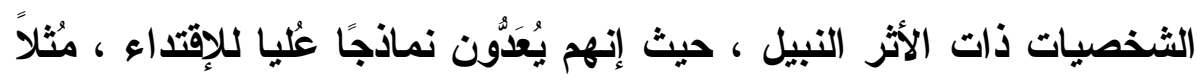
رفيعة للاحتذاء . و هذا لا يمنع أن يكون لكل كاتب من الكتاب روئية خاصة في معالجة أحداث التاريخ ، ورسم شخصياته . لونع ان لكون

و الجارم في ذلك استنبط الأحداث من حياة شخصيات قصص تراثية أدبية للربط بين وقائع التاريخ في الفترة المر اد تصويرها. مثل (المعتمد بن

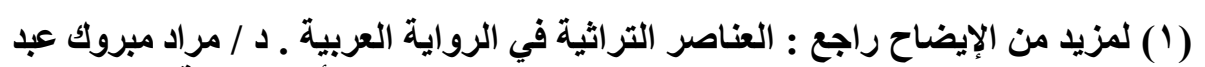

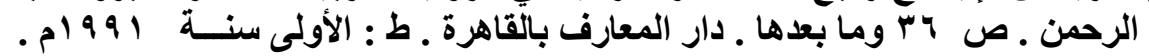


عباد ، وعمارة اليمني ، وأبي فراس الحمداني ، وأبي الطيب المتتبي ،

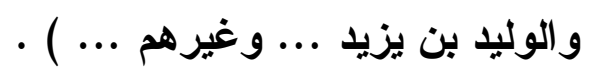

من هذا المنطلق فإن الأحداث التي تناولها الكاتب في قصصه ، هي أحداث و اقعية مستمدة من سير شخصيات كانت موجودة بالفعل في الحياة ، ثم وردت في كتب التراث الأدبي ، أو التاريخي ، أو هما معًا .

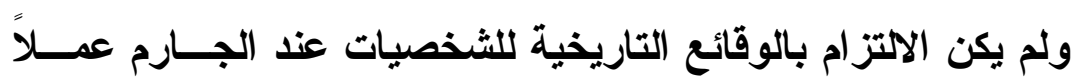

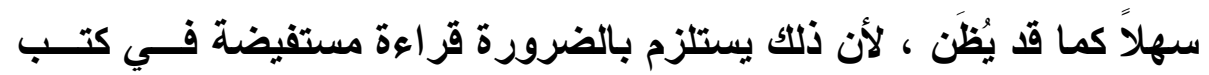
التراث المختلفة التي احتوت لسير هذه الثخصيات ، وموازنة شاملة بـين الثين

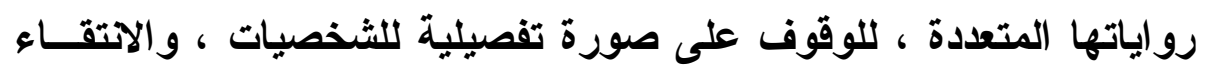

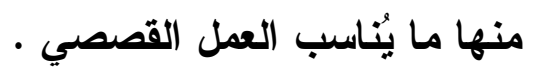
وقد اعتمد الجارم في ذلك على تراجم الــشعراء العـرب القــدماء

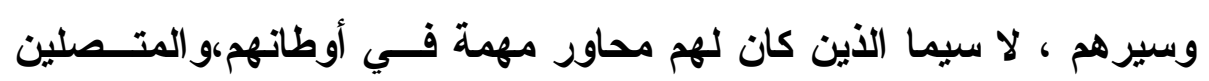

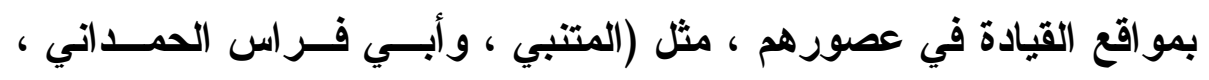

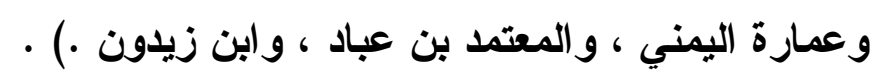

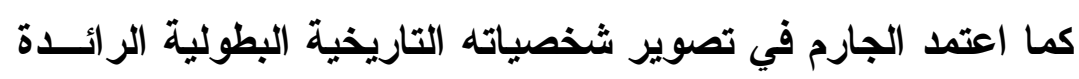

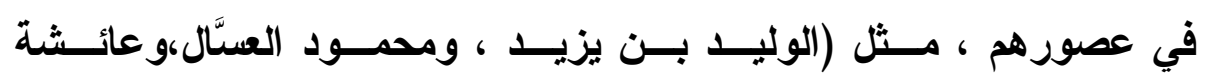

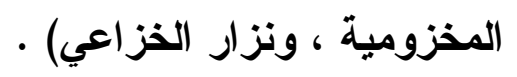

من هنا فإن سبير الثعراء الكبار، ثم الأبطال التاريخيين العظام كاتت

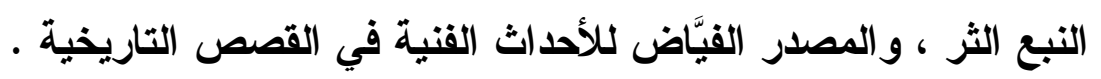
ولسوف نوضح ـ بإذن الله تعالى ـ نهج الكاتب في تكوين الأحداث و الثخصيات ، وبناءه الفني في تصميمه القصصي . 


\section{أولاً : فارس بني حمدان}

لا غرو في أنه غالبًا ما يكون التلخيص أو الإيجاز تسشويهًا نــافرًا

لجمال سياق القصة ، على حد تعبير الأستاذ سيد قطب في قوله :-

(و الصعوبة التي تواجه ناقد القصة أنه لا يملك عرض الجمال الفني

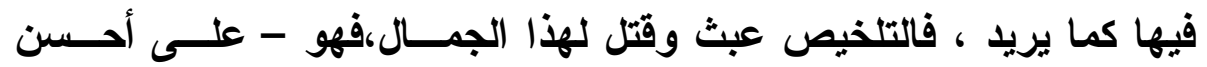

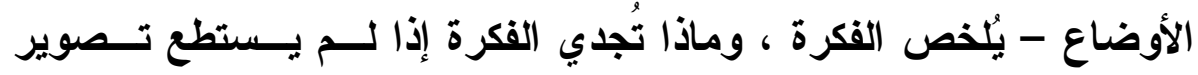

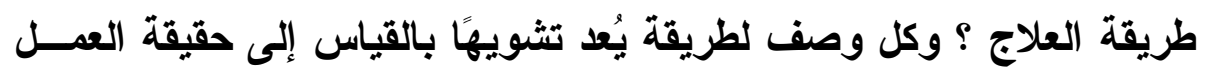

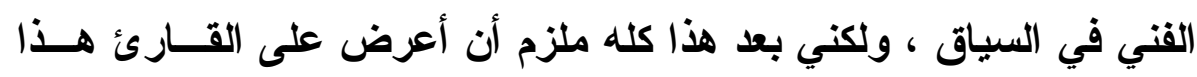

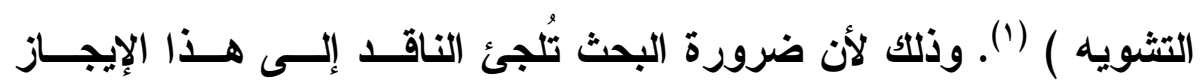

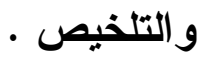

من هنا وجلت نفسي مضطرًا للتلك ، بالإضافة إلى أنني لا أستعيض

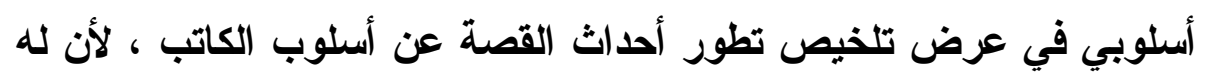

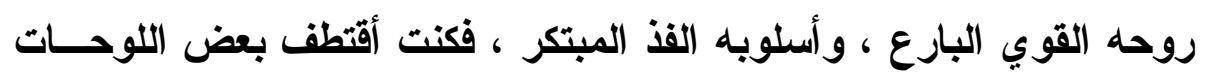
و المو اقف التي يستطيع بها القارئ أن يلم بالأحداث قدر الإمكان .

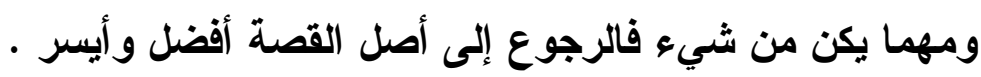

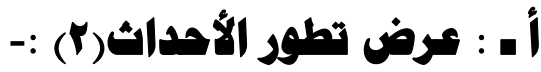

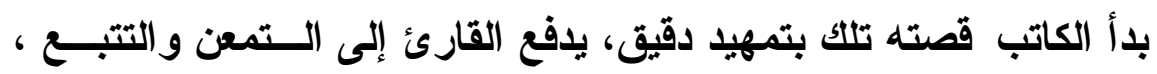

وذلك من خلال تسجيل قصة حياة الثـاعر الفارس (أبي فراس الحمــداني ،

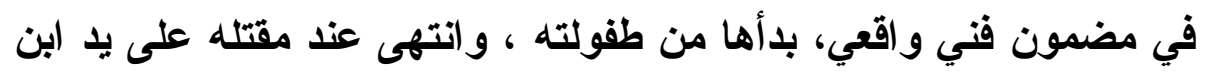

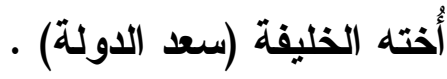

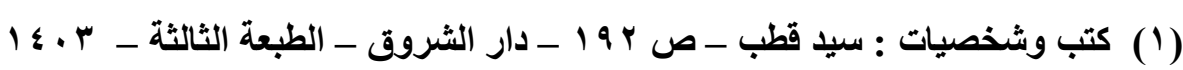

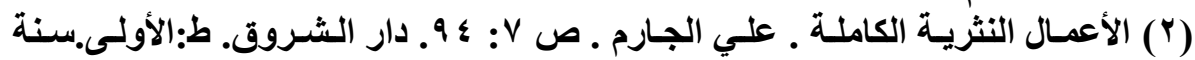

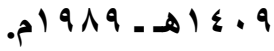




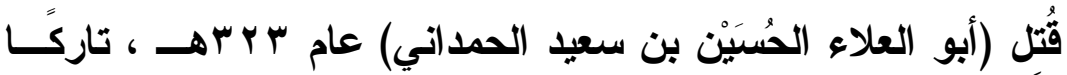

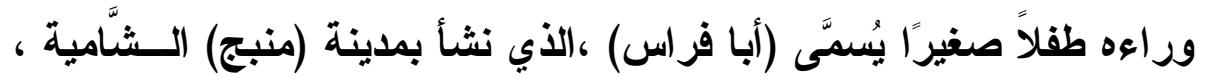

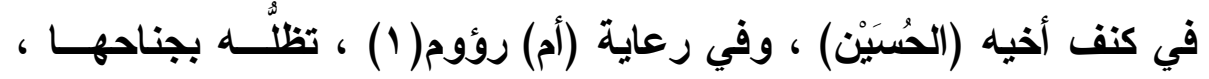

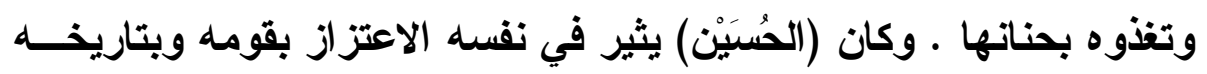
المجيد ، ويحفِّه إلى العظمة و السيطرة و البطولة . .

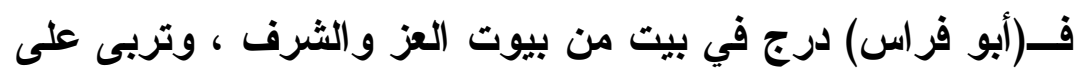

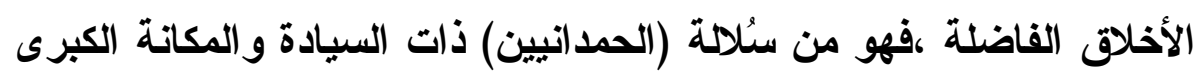

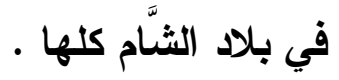

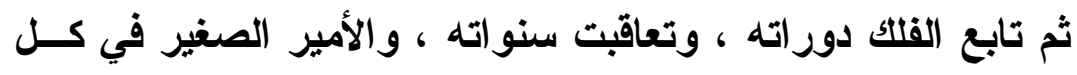

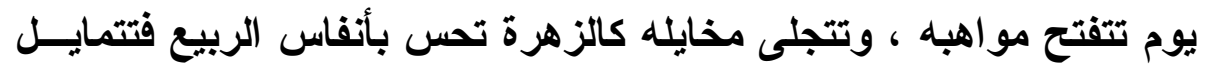

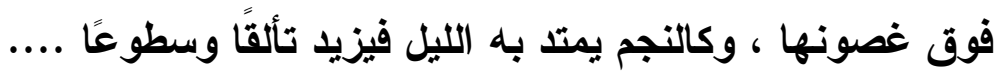

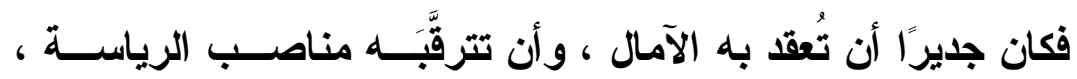
وتتهيأ له صدور المحافل ..... وبعد سنوات يثب أبو فراس عن الطوق ، ويُصبح واحدًا من أقوى المئ

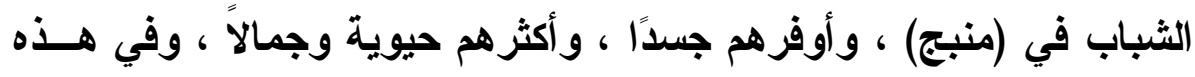

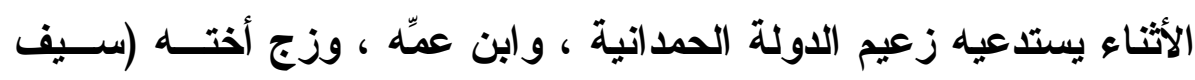

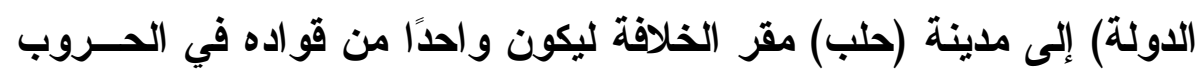

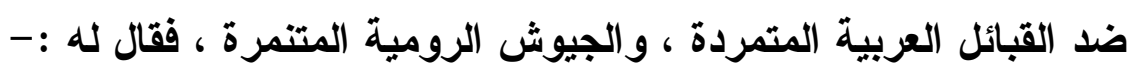

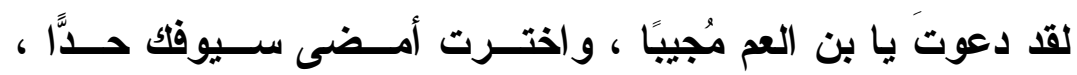

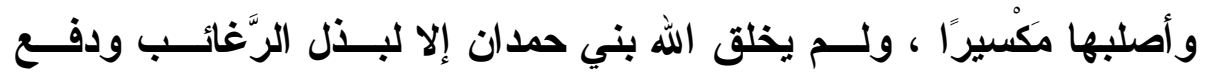

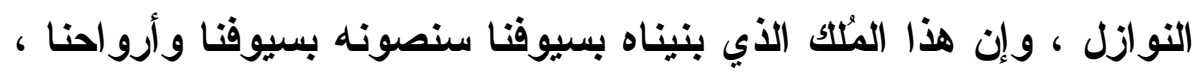

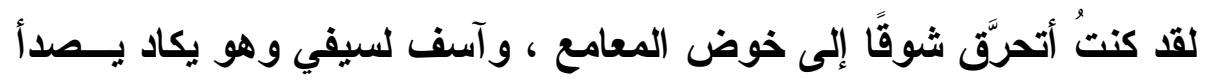

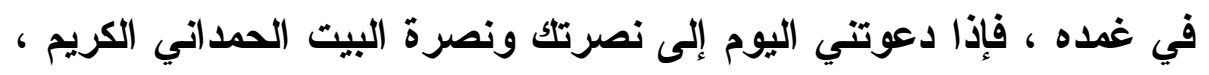




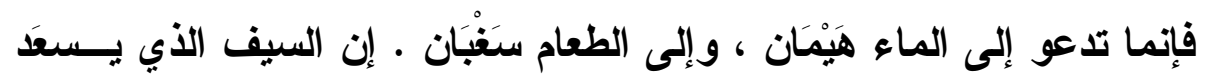
بالحروب إلى جاتب سيف الدولة لسيد السيوف ل...

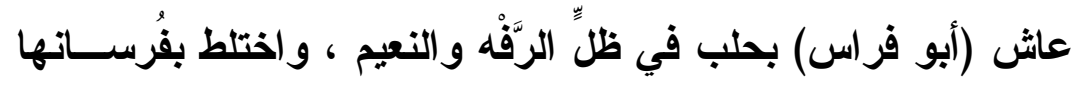

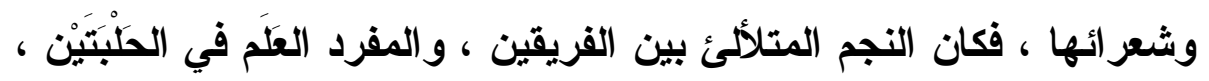

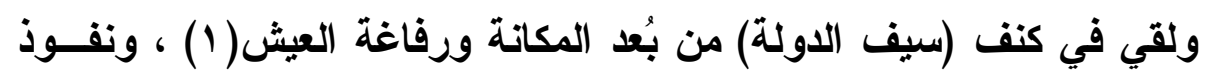

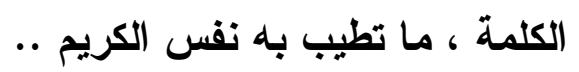

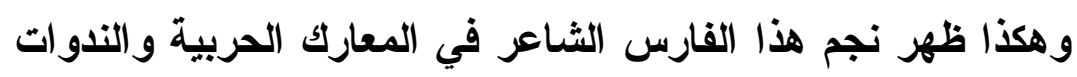

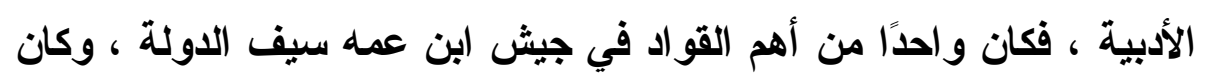

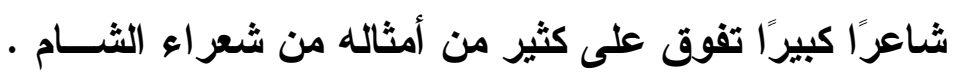

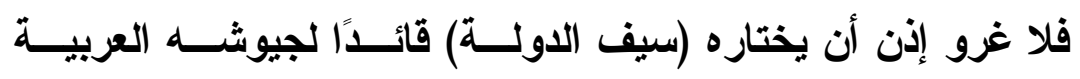

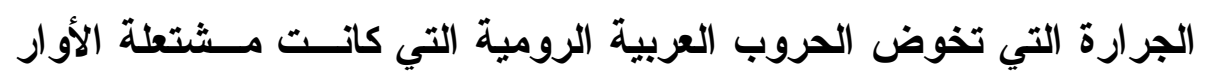

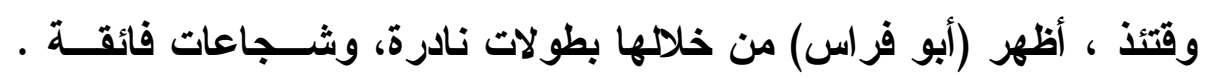

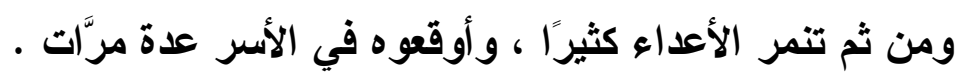

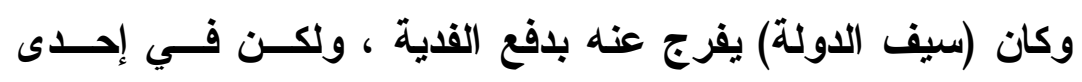

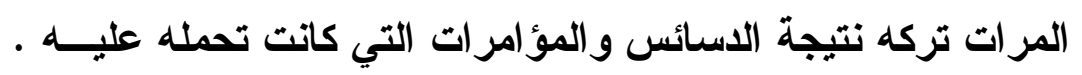

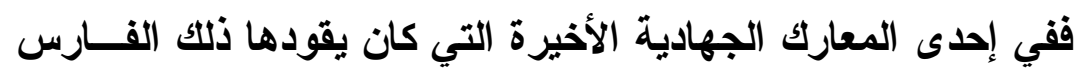

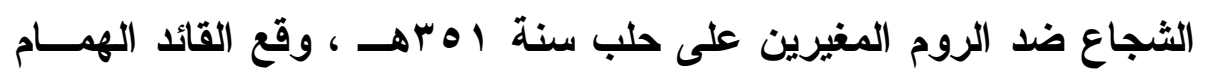

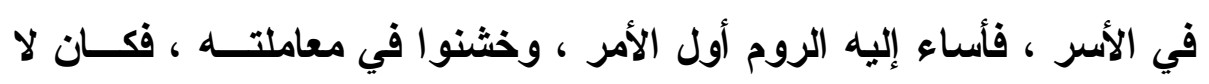

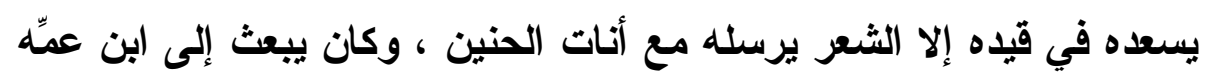

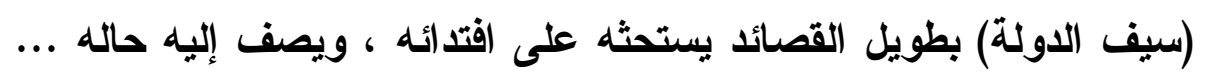

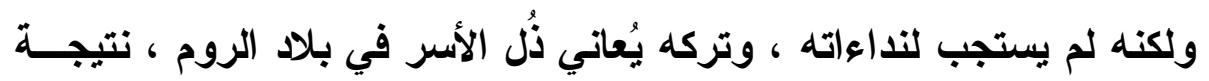

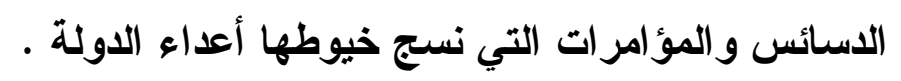
ولم ينقذه سوى زوجه (نجلاء الخالدية) ببعض الحيل .... 
وتمر الأيام ويموت (سيف الدولة) ، ويتولى الأمر من بعـــه ابنــه

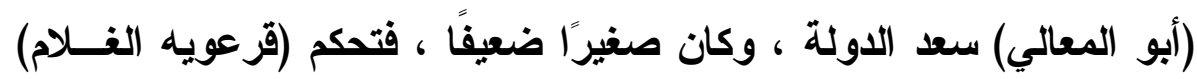

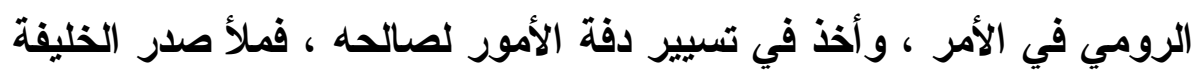

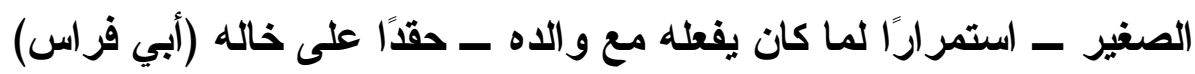

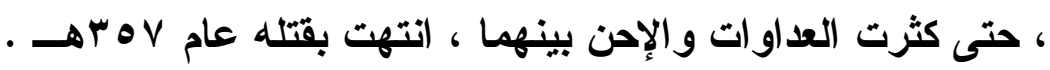
*** $* * * * * * * * * *$

\section{ب ـ الفكرة والهدف :-}

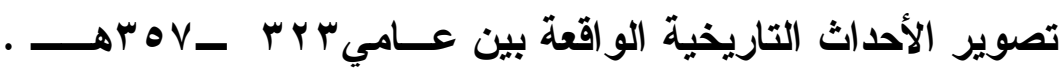
وكاتت كالتالي : 1 الخليفة العباسي (الرَّاضي) . r ـ تسلل (العجم) إلى مناصب الدولة العباسية العُليا ،مما أضعفها ، وجعل

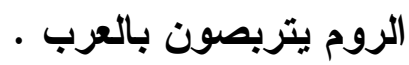

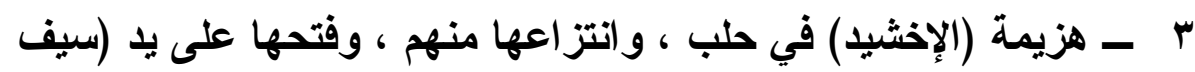

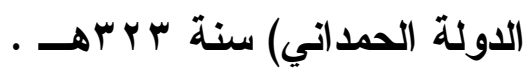

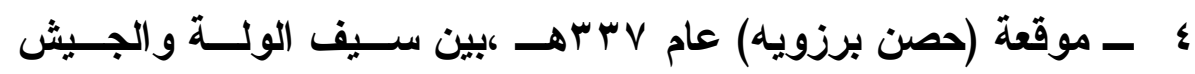

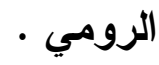
ه - موقعة (سروج) ، التي قادها (أبو فراس) من قِبَل ابن عَدِّهـه (ســيف

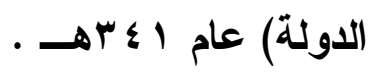

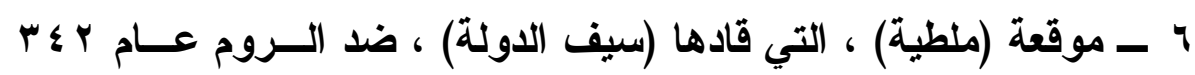
V - V موقعة (حصن الحدث) ، التي قادها (سيف الدولة) ، ضد الروم عسام . $\rightarrow r \leqslant r$ 


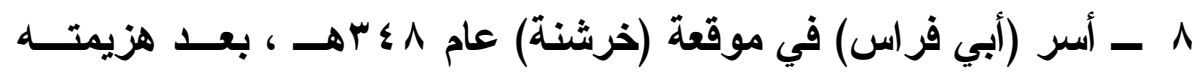
فيها .

9 ـ هزيمة (سيف الدولة) بعد هجوم الروم على (حلـب) ، و أســر (أبــي

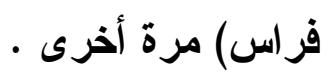

. 1 ـ موت (سيف الدولة) ، وخلافة ابنه (أبي المعالي سعد الدولة) له .

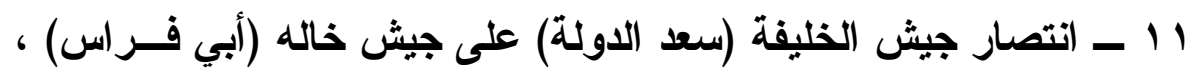

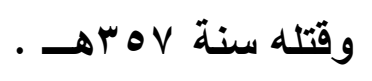

$$
\text { **** } \quad \text { ***** } * \text { * } * * *
$$

\section{ثانياً: : الشاعر الطموحة}

$$
\text { أ. : : عرض تطور الأهداث(1) :- }
$$

صور الكاتب في هذه القصة حياة شاعر العربية الكبير (أبي الطيب

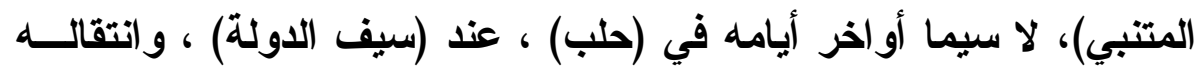

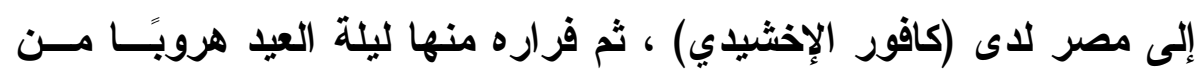

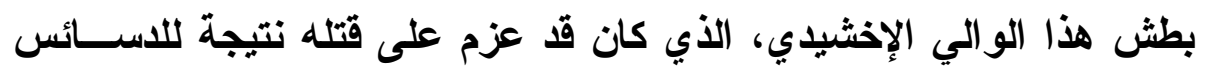

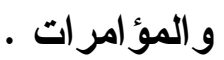

اتخذ (سيف الدولة) من المتنبي ، الثاعر المُفضّل للاولة ، ونديمه

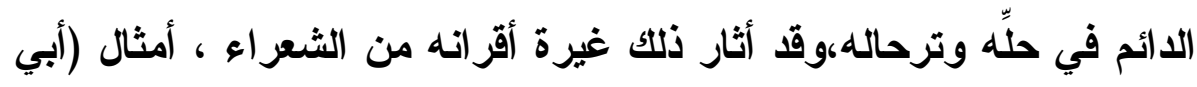

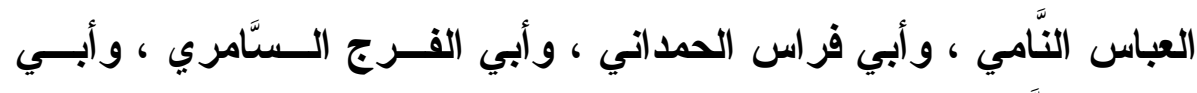

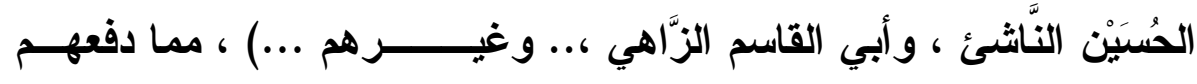

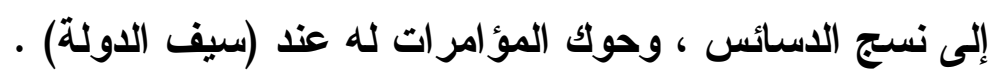

(1) الأعمال النثرية الكاملة . علي الجارم . صه9 : 11 أ. دار الشروق ـ ط : الأولى .

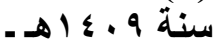




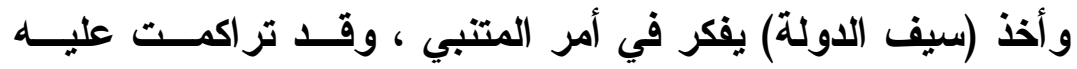

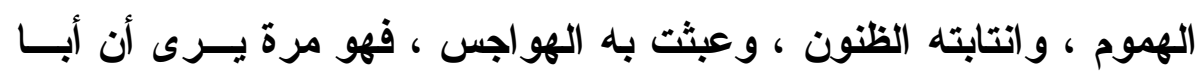

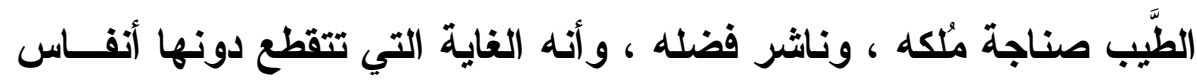

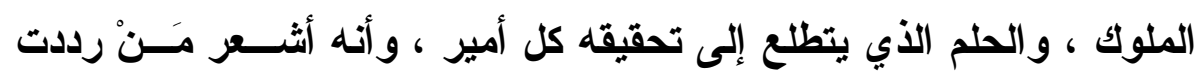
أصداعه آفاق العرب ...

ولكنه لا يفتأ حتى تهجم عليه الوسعاوس من كـلـ مكــان صــارخة

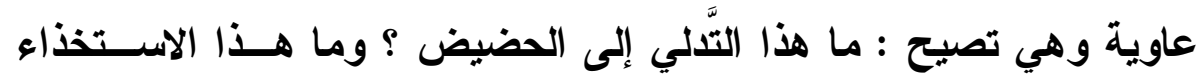

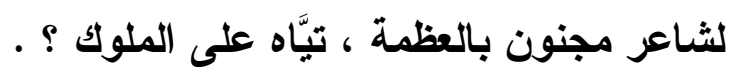

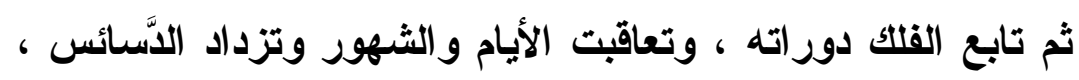

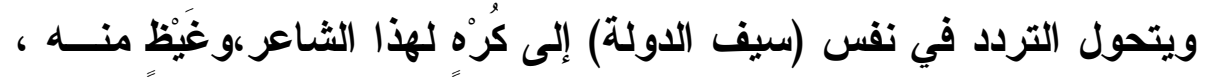

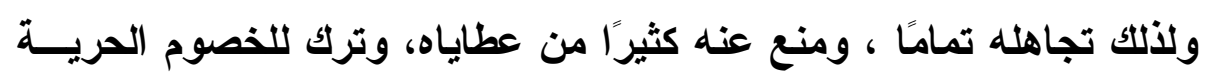
حتى استطالو ا عليه في حضرتها .

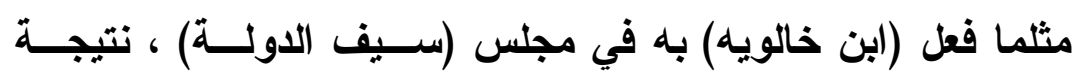

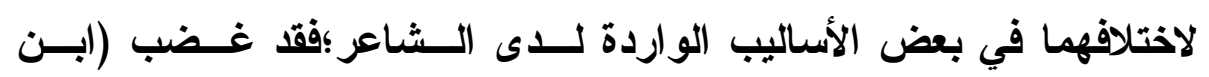

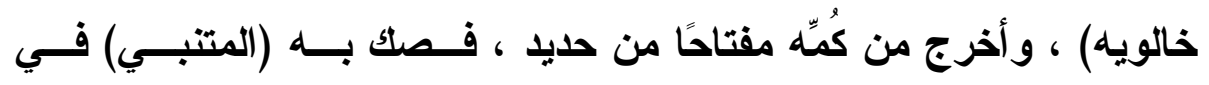

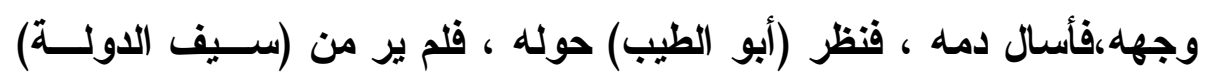

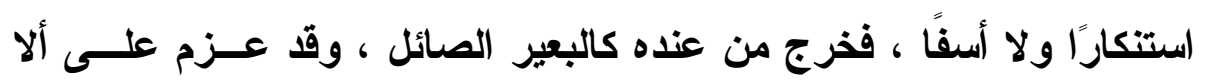

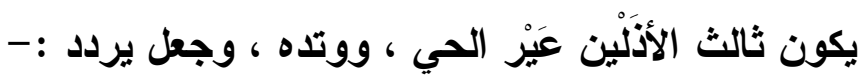

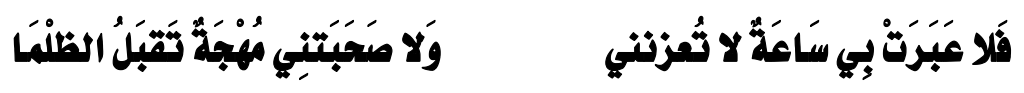

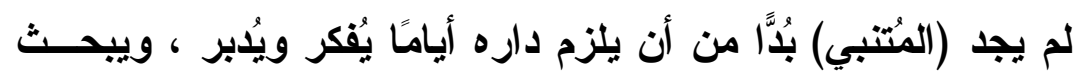

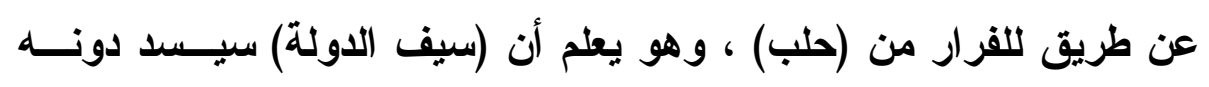

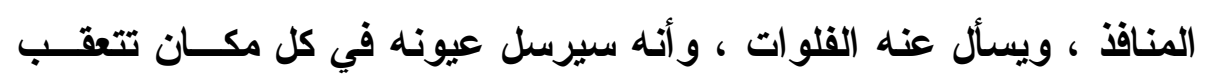

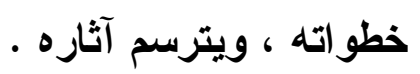




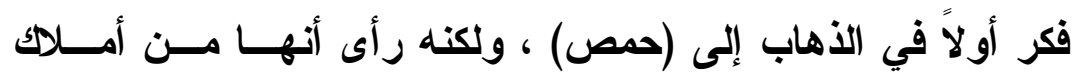

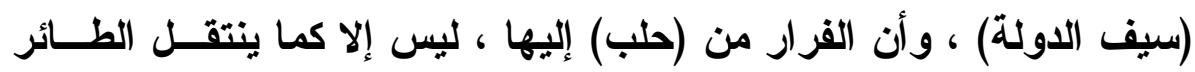
الحبيس في قفصه من ركن إلى ركن .

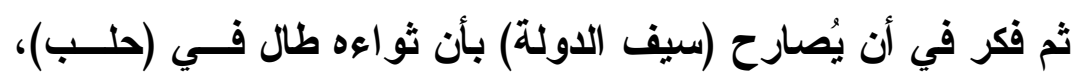

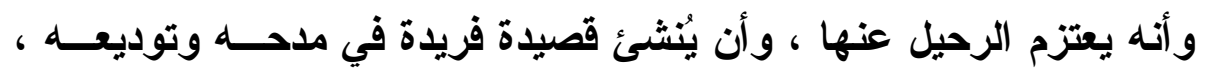

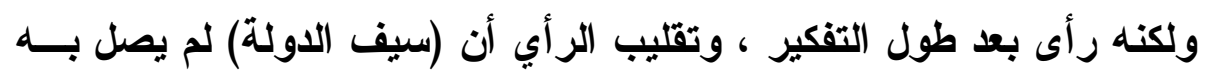

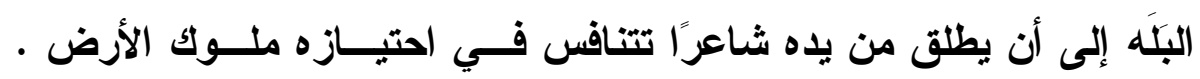

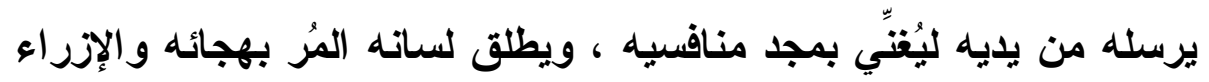

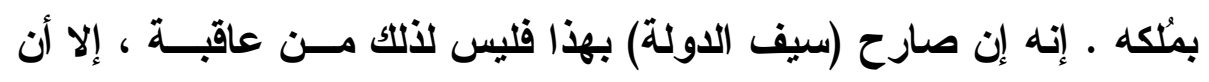

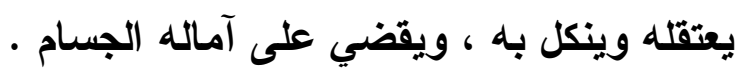

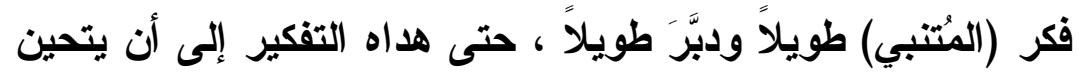

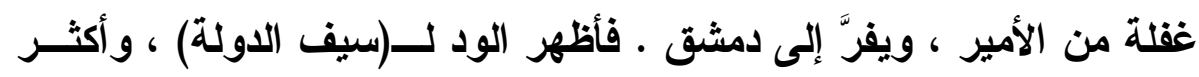

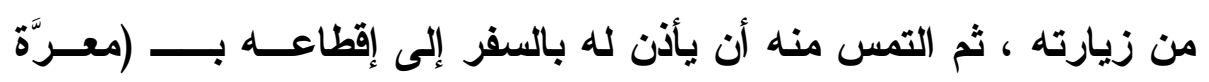

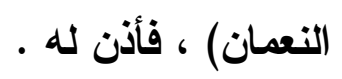

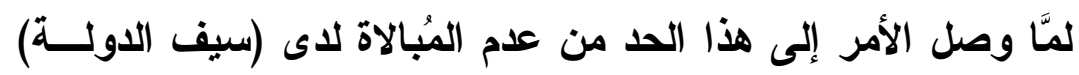
ترك (المُتببي) (حلب) ، وقد حفزه على ذلك عدم تحقق طموحاته في الولاية

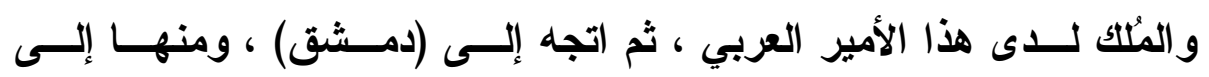

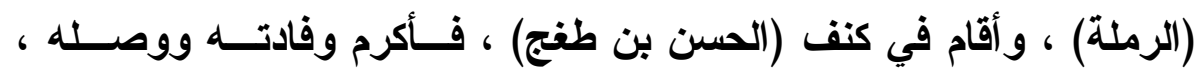

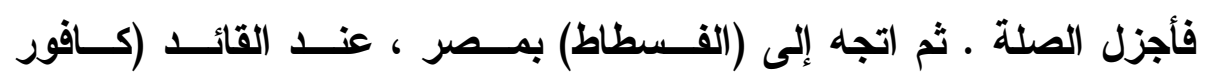

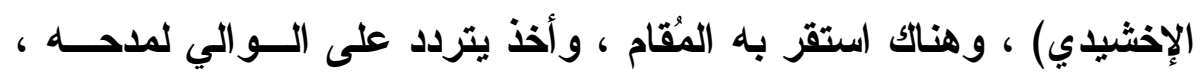

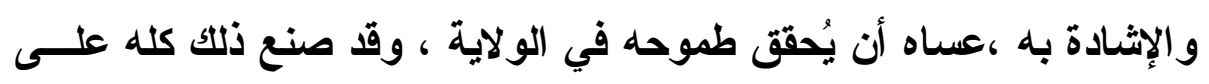

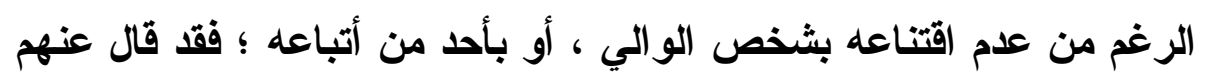

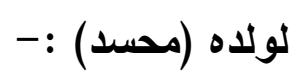




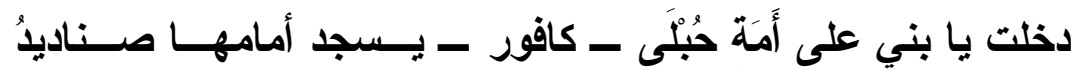

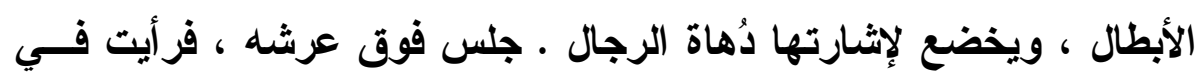

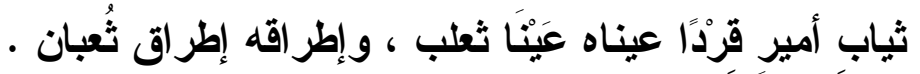

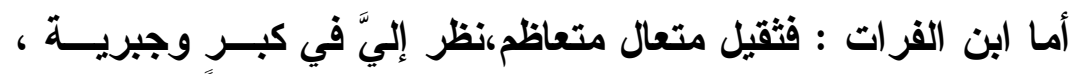

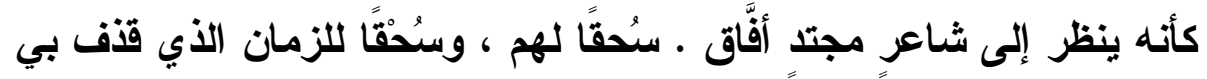

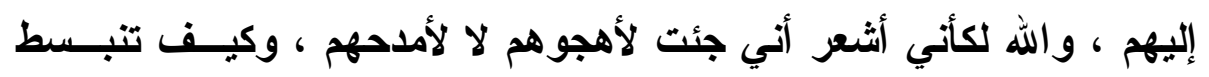

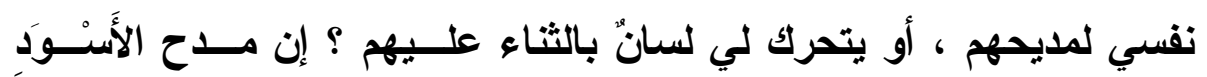

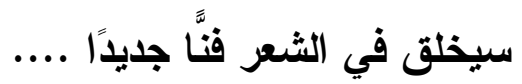

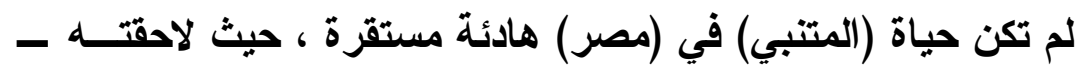

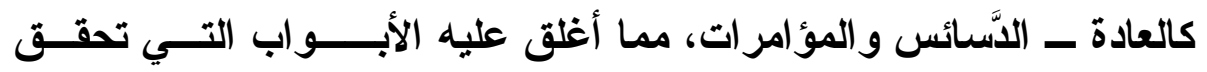

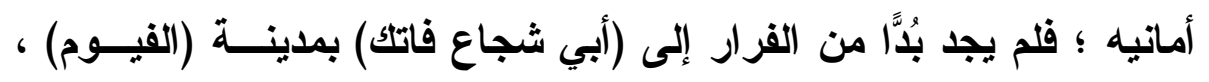

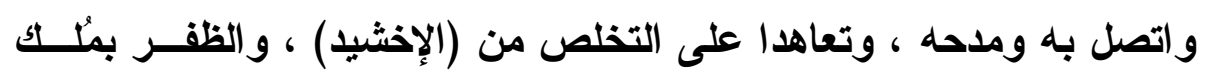

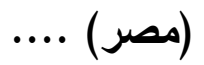

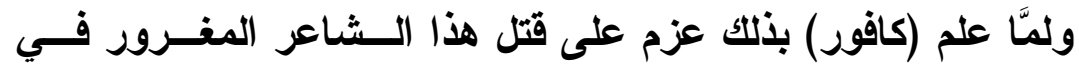

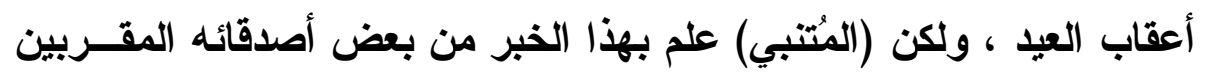

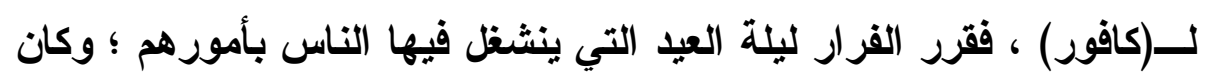

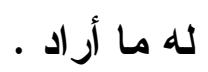
**** $* * * * * \quad * * * *$

\section{ب ب. : الفكرة والهدف :-}

اهتم الكاتب في هذه القصة بتصوير وقائع تاريخية حقيقية جرت في

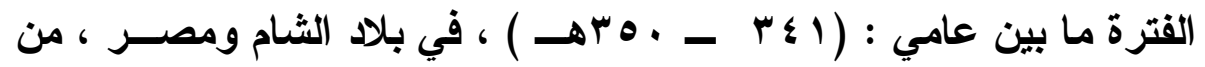
أهمها :-

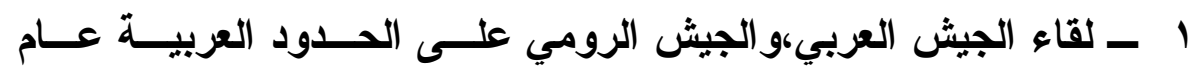

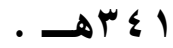


r ـ غزوات الجيش الرومي المستمرة علــى أرض العـرب ، و إجهــاض

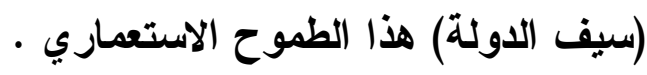

r - الصر اع الدائم بين (أبي شجاع فاتلك) ، وبين (كافور الإخشيدي) للفوز بحكم مصر .

؛ ـ موت (شبيب العقيلي) مسمومًا بعد معركته ضد (كافور الإخشيدي) ... **** $\quad * * * * \quad * * * *$

\section{ثالثاً :خاتهة المطاف}

\section{أ ـ عرض تطور الأحداث(1) :-}

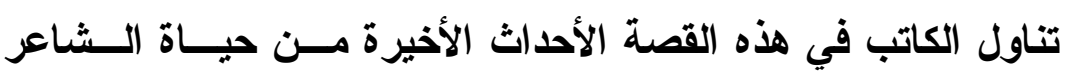

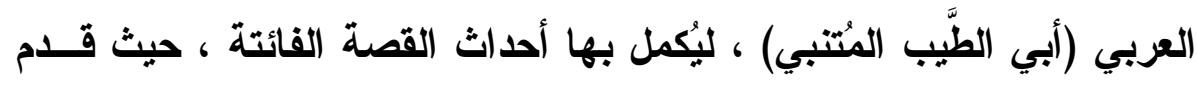

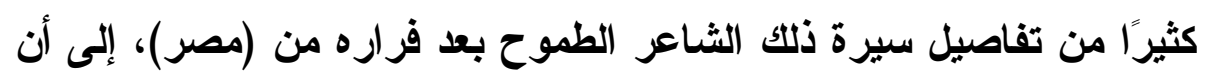

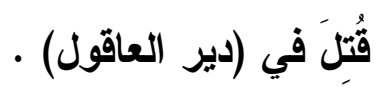

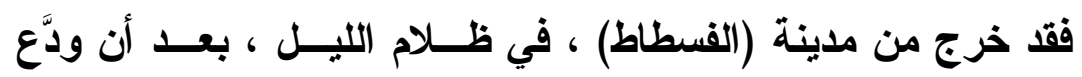

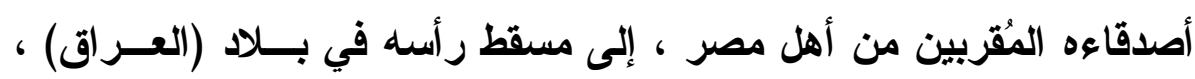

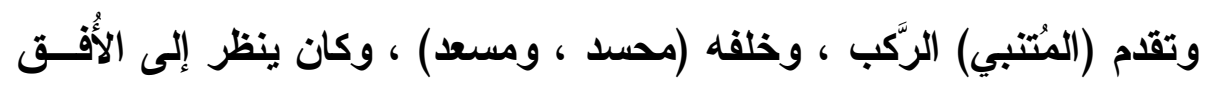

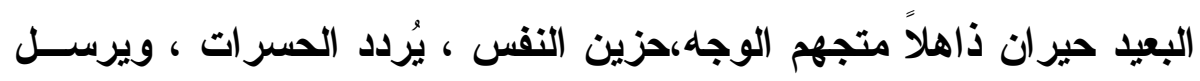

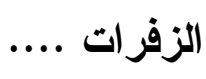

يصل (المُتنبي) إلى الكوفة ، ويستقبله أهله ، وعلى رأسهم زوجـهـ

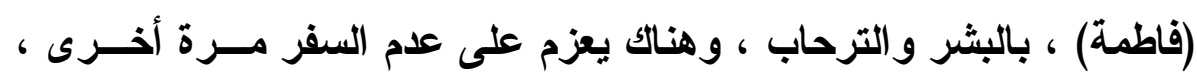

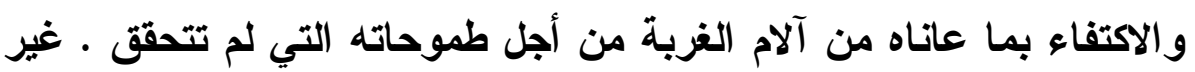

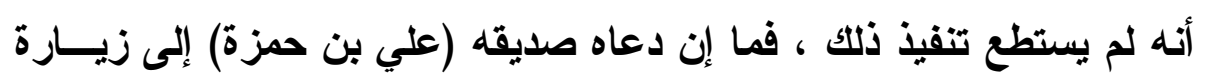

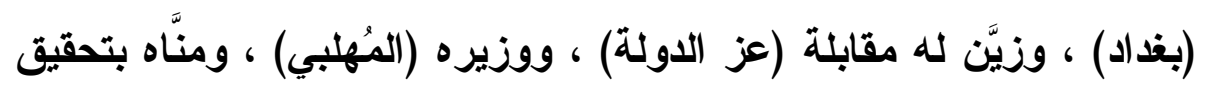

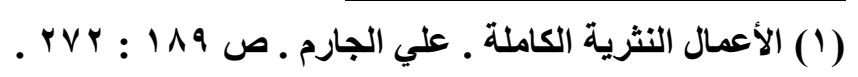
- 
أُمنياته في رحابهما حتى وافق مسرعًا ؛ أعد الرَّكائب مسرعًا متلكهًا ، وقَتَّل

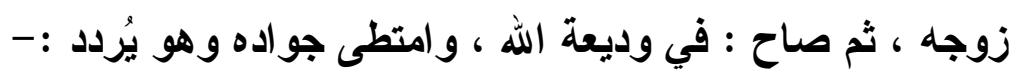

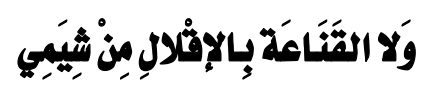

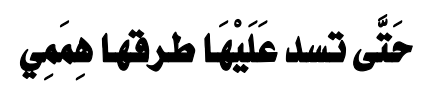

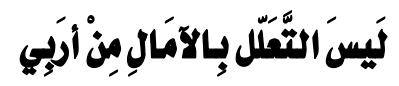

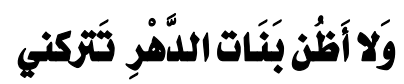

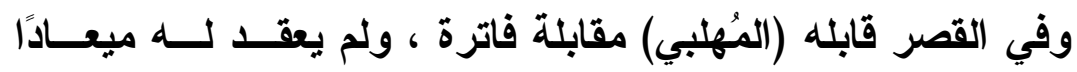

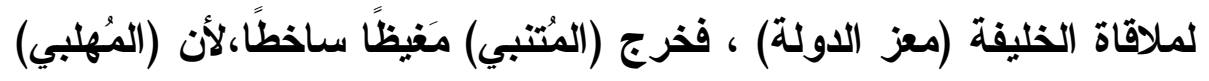

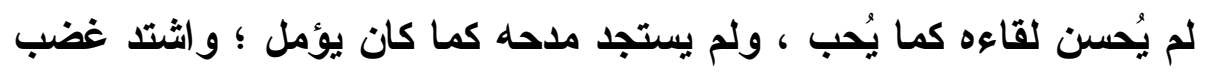

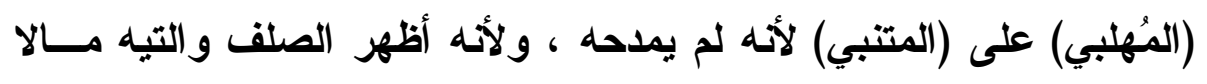

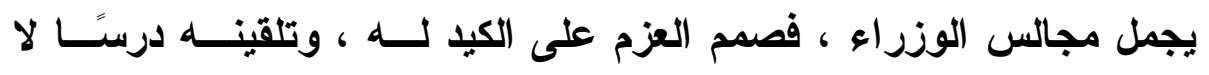

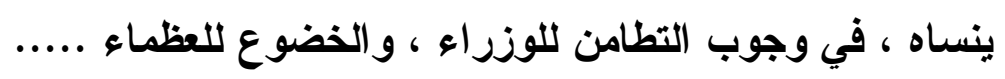

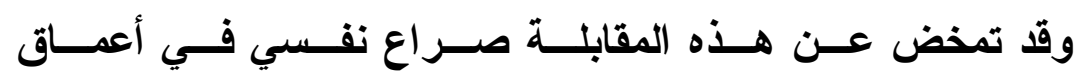

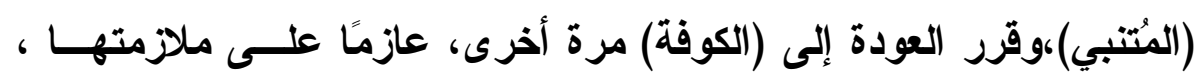

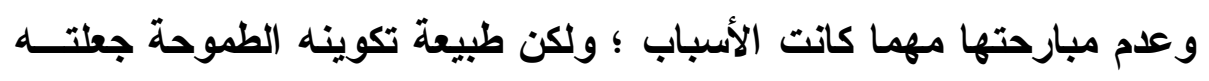

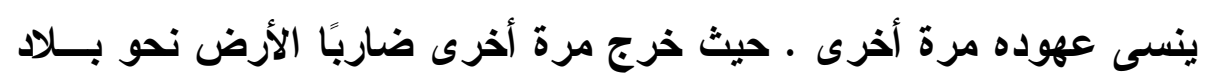

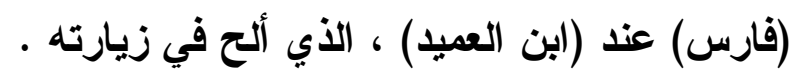

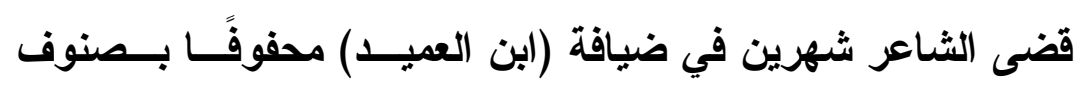

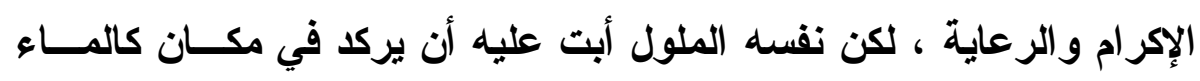

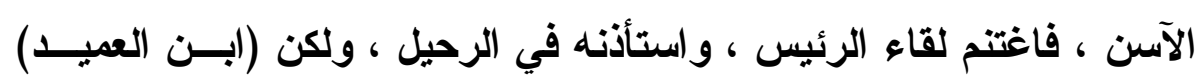

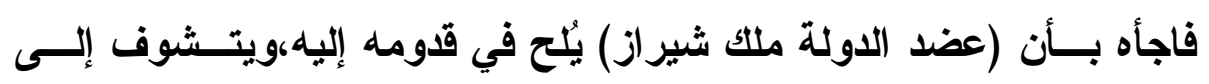

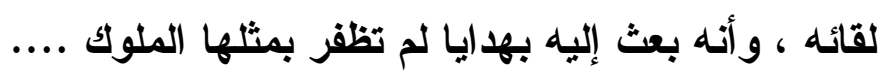

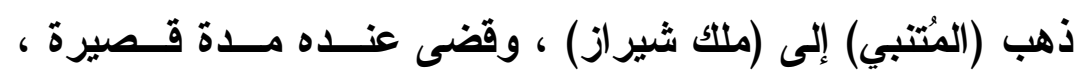

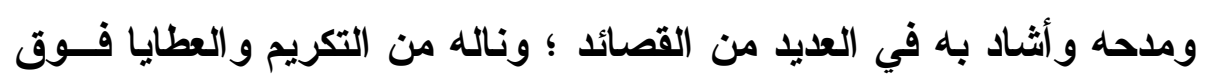
ما كان يتمنى . 
وتمر السنون ، ويحن (المُتتبي) إلى وطنه و أهله ، فاسـتأذن فــي

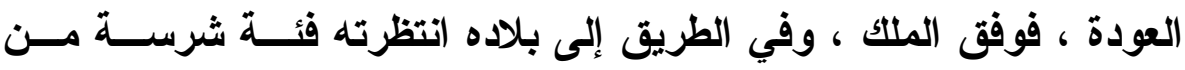

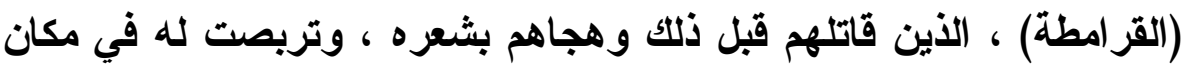

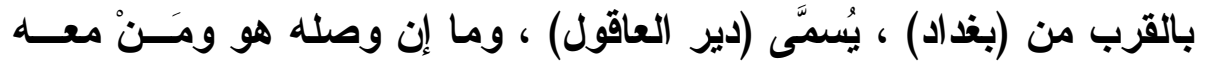

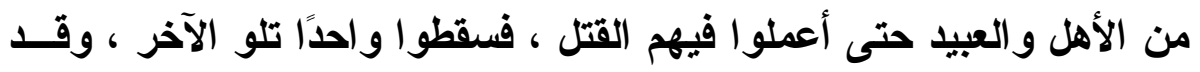

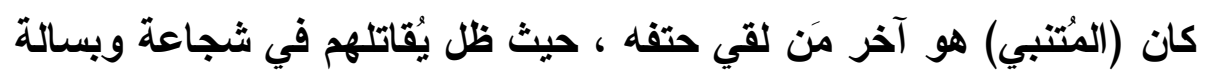

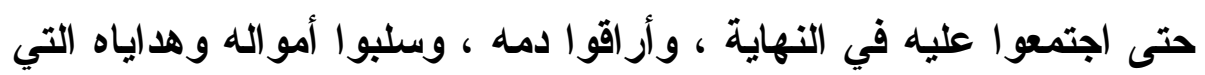

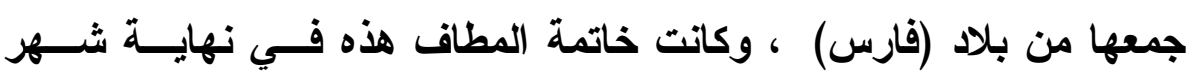

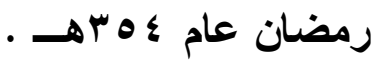

\section{******** $*$}

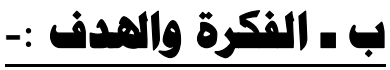

صور الكاتب في هذه القصة وقائع تاريخية متصلة بتاريخ (مصر ،

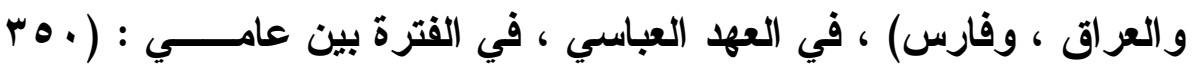

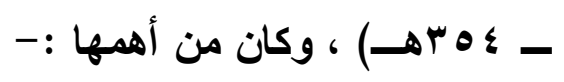

1 ــ القضاء على (كافور الإخشيدي) بعد مؤامرة (فاتــــ) لإنهــاء حكمــهـ

$$
\text { لمصر - (ل) }
$$

r ـ كم (القرامطة) الفاسد في (الكوفة) ، في منتـــف القــرن الرابــع

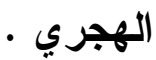

r - خروج (سيف الدولة) لملاقاة الروم على الحدود العربية .

**** $* * * * * * * *$ 


\section{رابعاً : شاعر هـك}

\section{أ ـ عرض تطور الأحداث(1) :-}

استمد الكاتب أحداث هذه القصة ، من قصة تاريخية حقيقية ، وهي

قصة الثاعر الأنلسي الثهير الملك (المعتمد بن عبَّاد) . وقث بدأها الكاتب من لحظة ميلاده ، حتى وفاته .

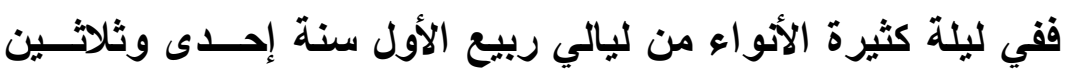

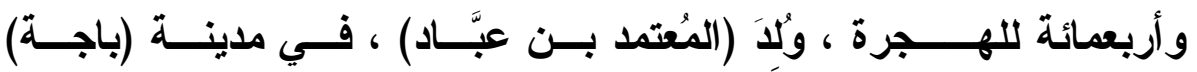

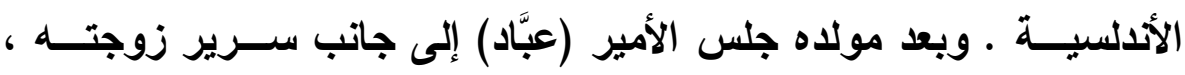

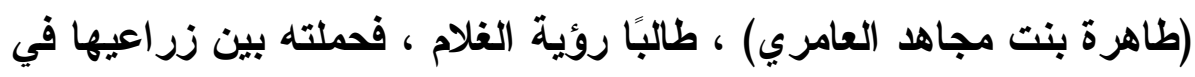

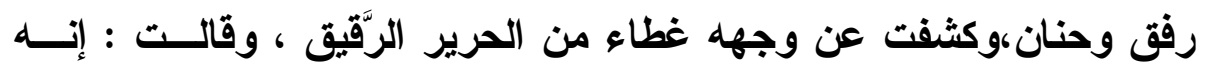

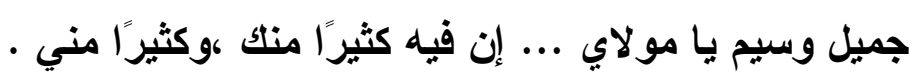

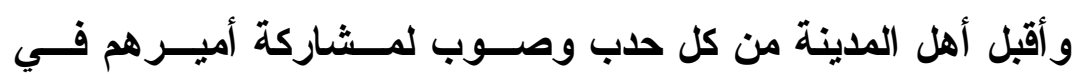

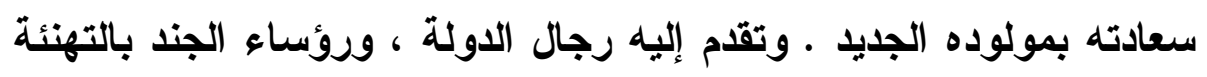

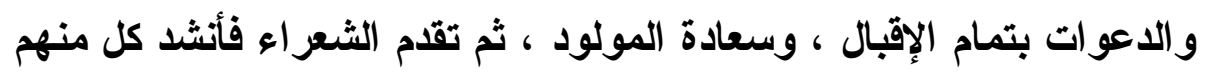

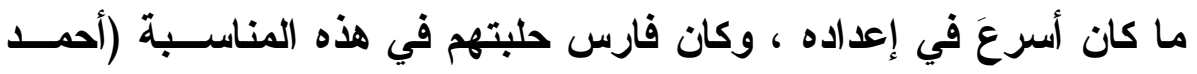

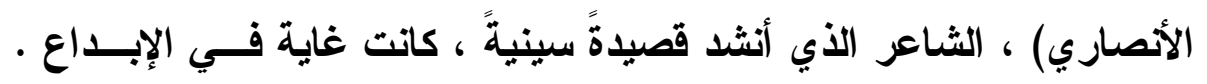
منها :-

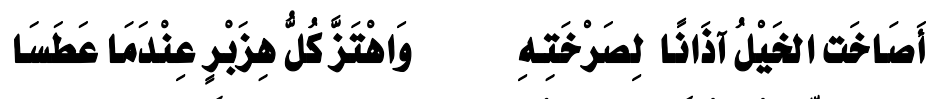

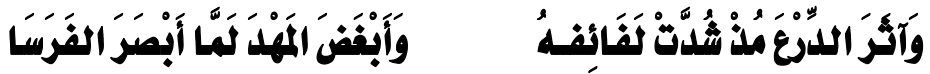

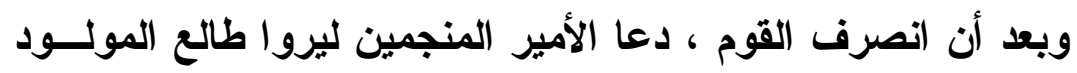

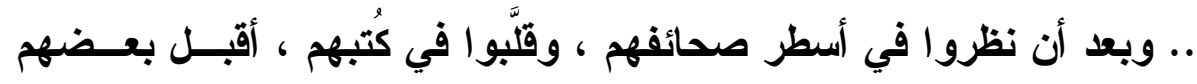

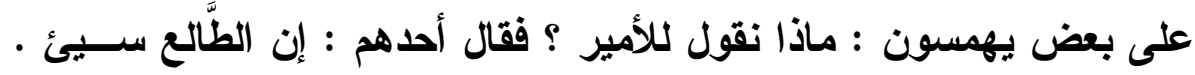

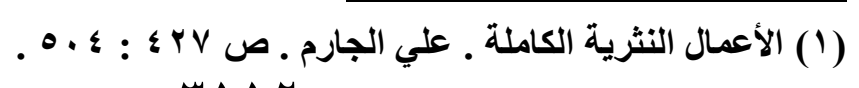




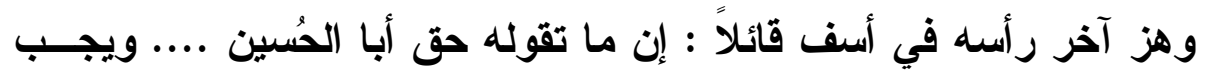

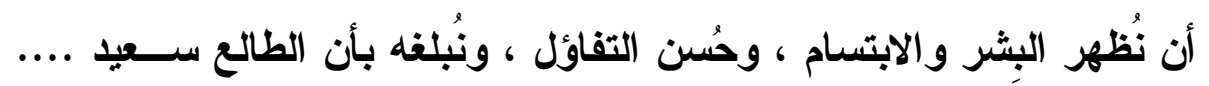
فخرجوا على هذا الرأي .

دار الفلك دورته ، ومضى نحو سنتين من ولادة (محمد بن عبَّاد) ،

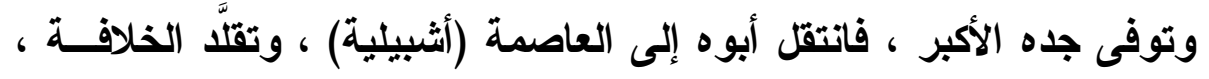
وأطلق على نفسه لقب (المعتضد) .

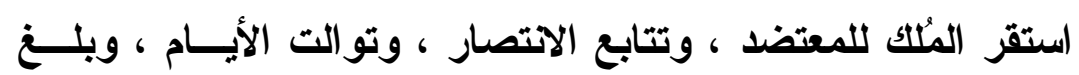

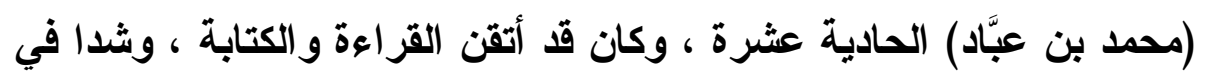

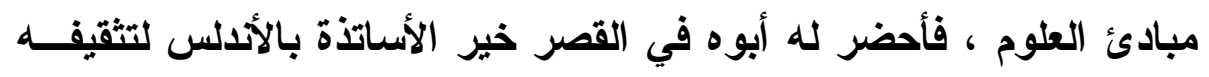

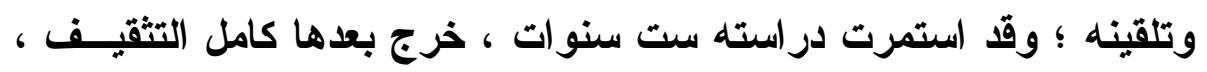

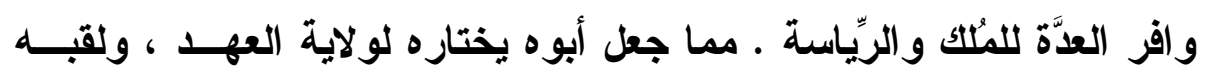

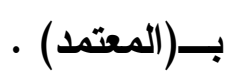
ويُقرر إرساله على رأس جيش له لإِقاذ أهل مدينة (مالقــة) مسن أميرهم الظالم (باديس بن حبوس) .

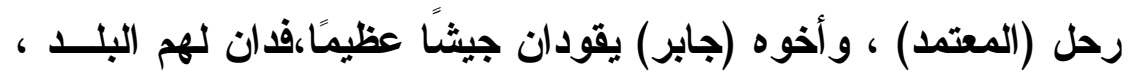

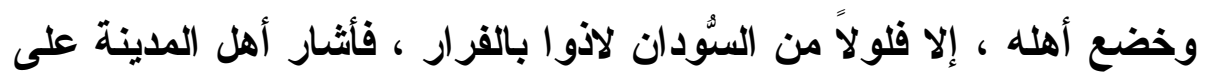

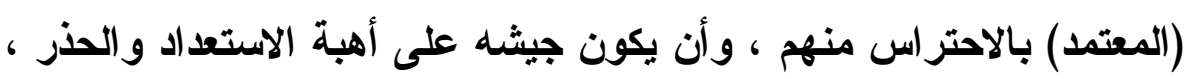

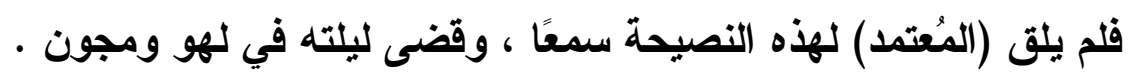

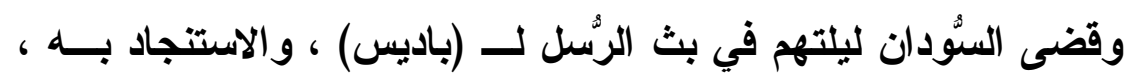

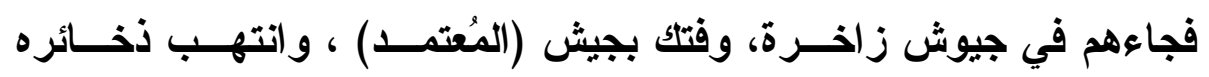

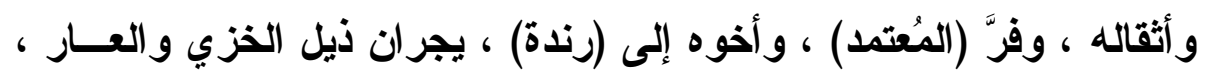
ويرهبان صولة أبيهما الجبَّار . 


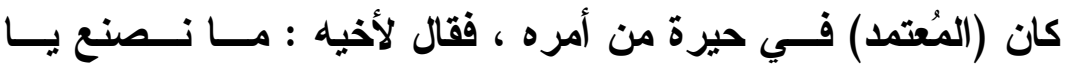

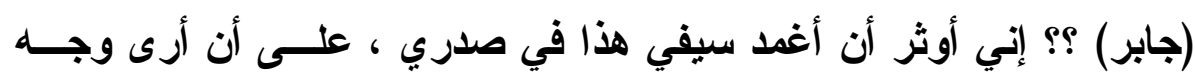

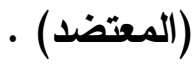

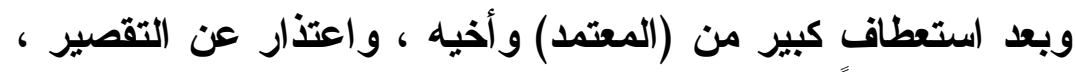

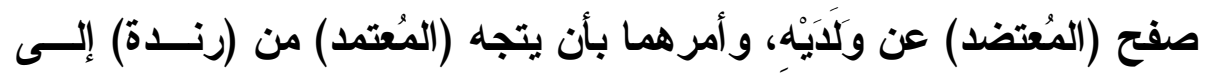

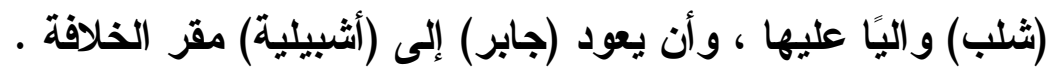

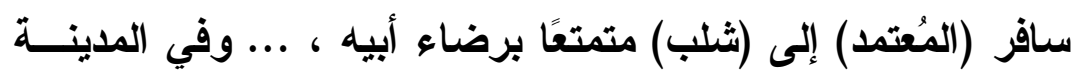

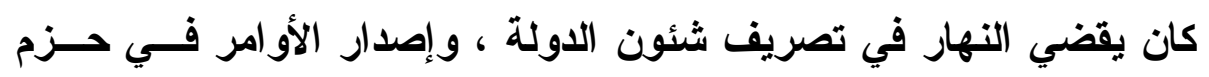

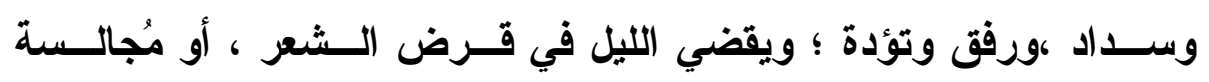

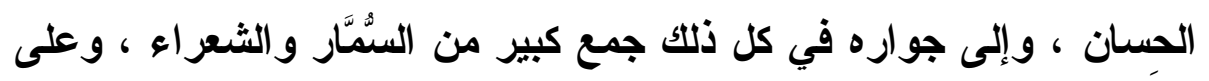

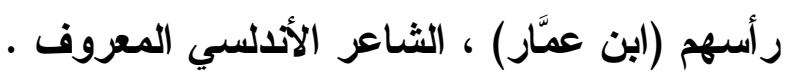

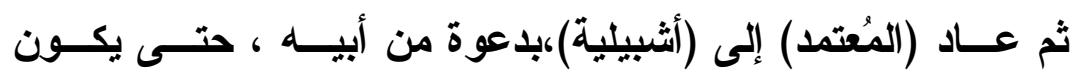

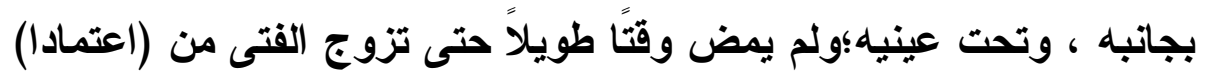

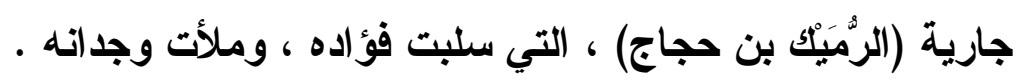

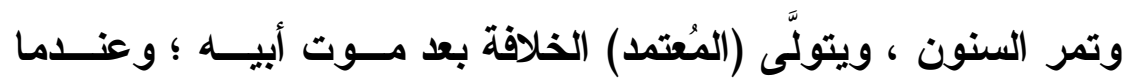

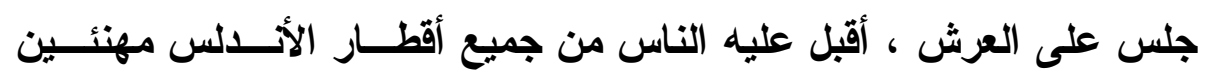

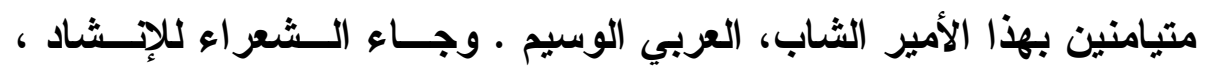

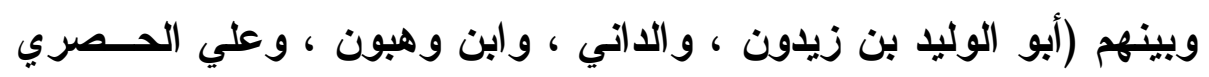

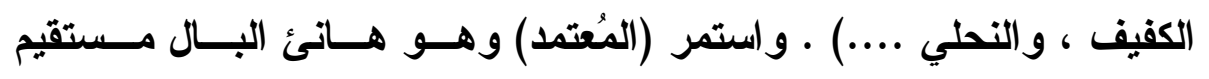

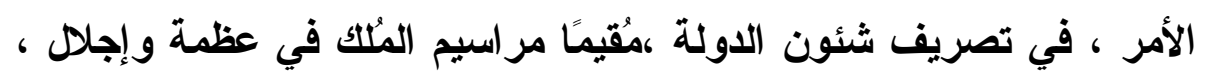

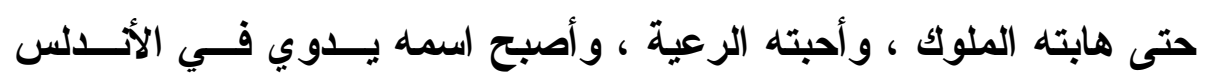

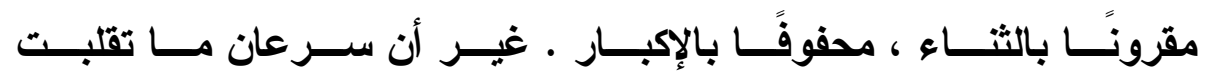

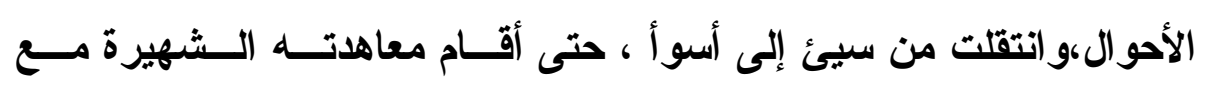

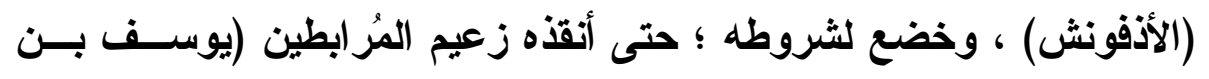




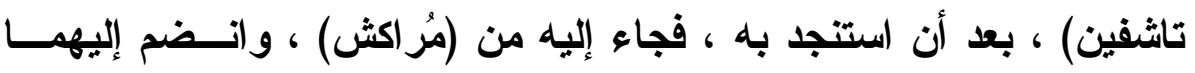

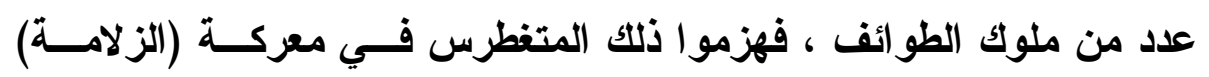

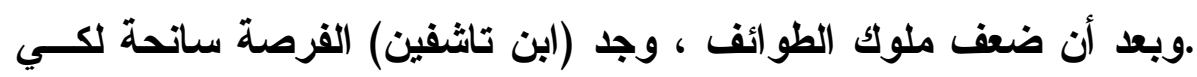

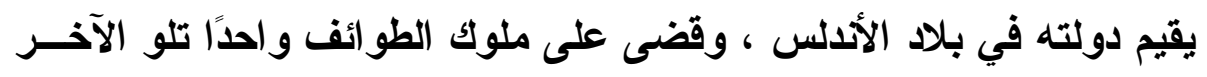

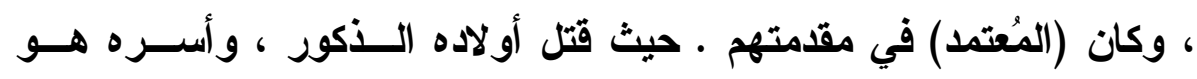

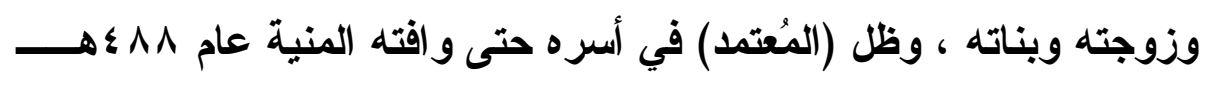

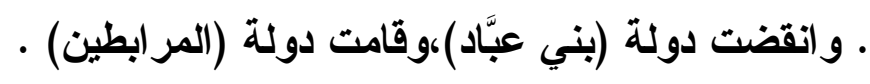
********

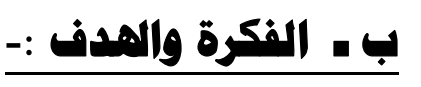

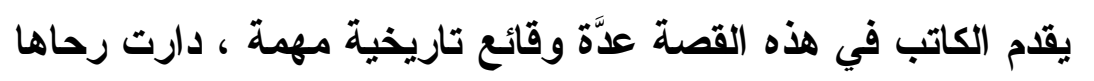

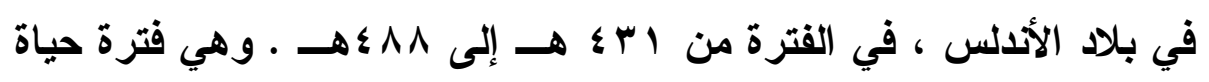

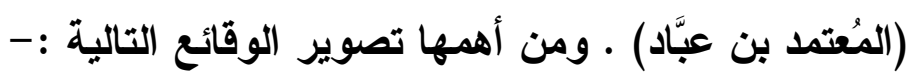

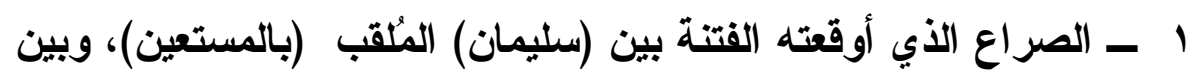

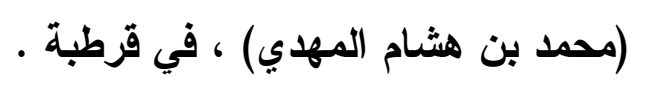
r- هزيمة (المعتمد) في مدينة (مالقة) ، وفراره إلى (رنده) خوفًا من أبيه (الخليفة) ( بزيمة )

rــ تحيّن الأسبان أي فرصة للقضاء على دُويْلات المسلمين وقتئذ . ؛ـ تولي المعتمد إمارة (أثبيلية) ، بعد موت أبئه أبيه (المُعتضد).

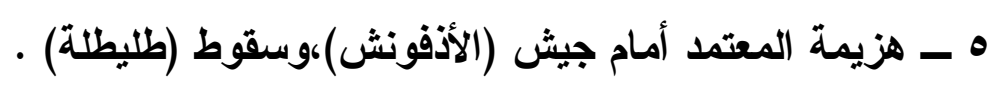

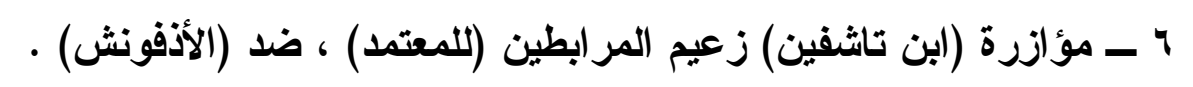

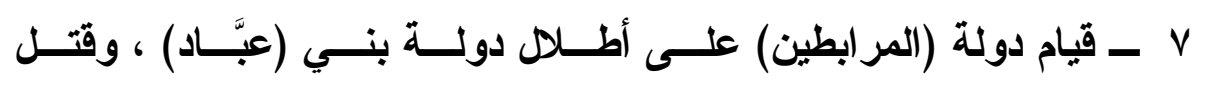

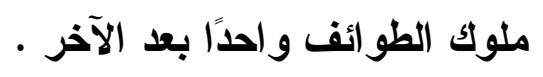




\section{خامساً : هاتف من الأندلس}

\section{أ ـ عرض تطور الأهداث(1) :-}

الهتم الجارم في هذه القصة بتصوير وقائع تاريخية حقيقية عن حياة

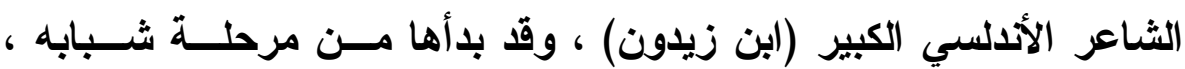
و واستمرت حتى وفاته .

عاش (ابن زيدون) في مطلع شبابه في مدينـــة (قُرطبـة) ، التـــي

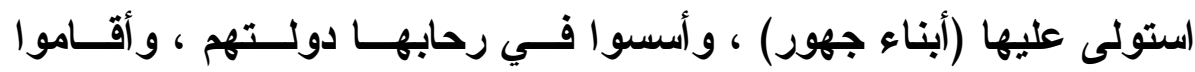
أركانها على يد (أبي حزم) عميد الجماعة ع.......

وكان هذا الثـاب الثـاعر محافظًا على حضور النــدوات الأدبيــة ،

وعن طريقها تعرف على شخصيات كثيرة كان لها أثر كبير فــي حياتسه ،

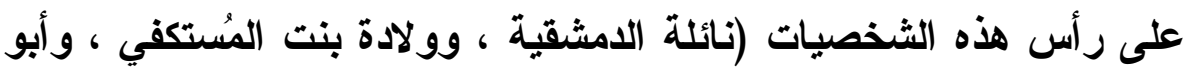
الوليد بن عميد الجماعة ، وأبو حفص بن برد ، و وابن عبدوس) .. ويدور الفلك دورته،وتجوب شهرة (ابن زيدون) ، فيبعث إليه (عميد

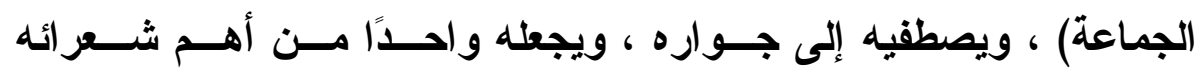

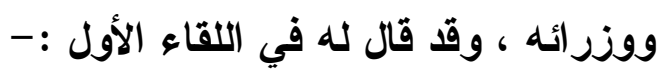

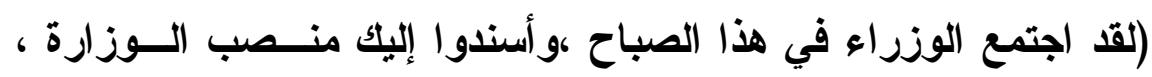

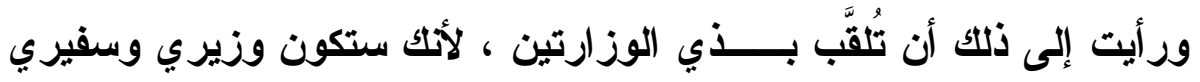
إلى أمر اء الأندلس) ...... أصبح (ابن زيدون) من علية القوم في (قرطبة) ، وأخذ يتقلب فــي

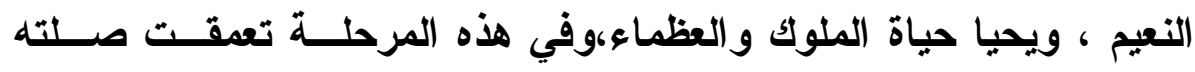

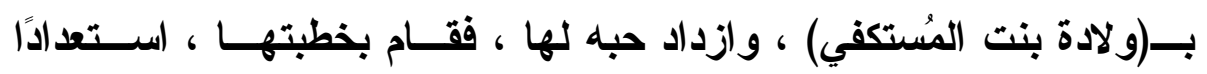
للزواج منها ....

(1) الأعمال النثرية الكاملة . علي الجارم . صه .0 : 117. 
ومع بزوغ نجمه في سماء (قُرطبة) ، كثر حاســدوه ، و النـــاقمون

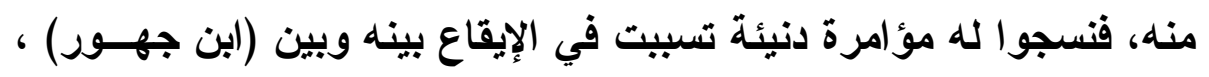

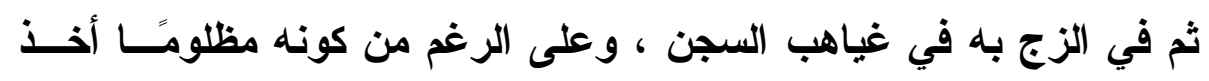

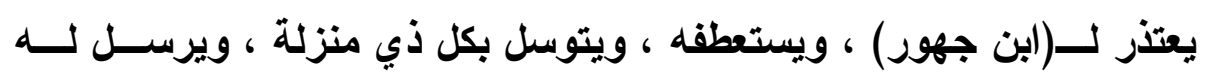

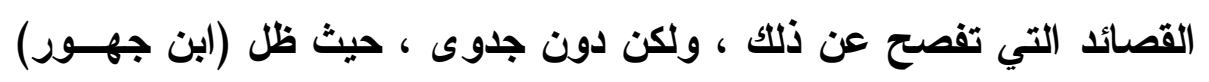
على موقفه، وصمم على ما أراد ....

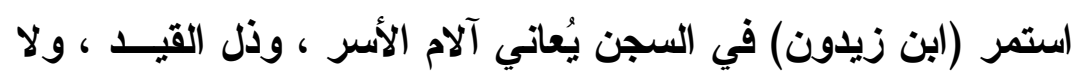

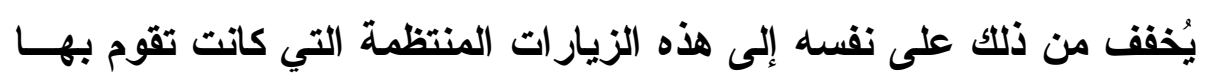

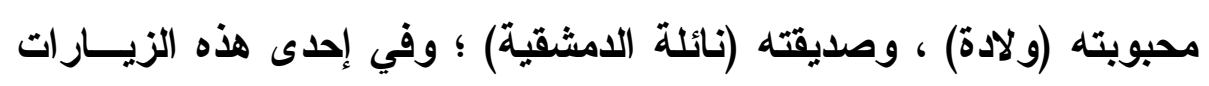

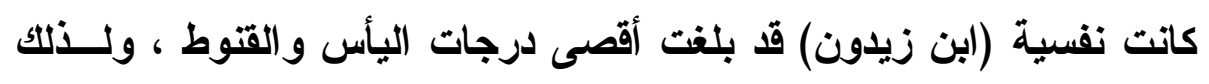

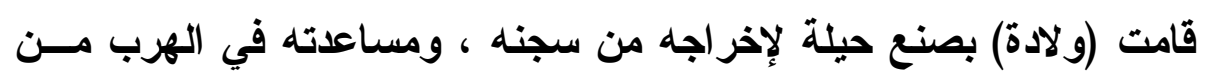

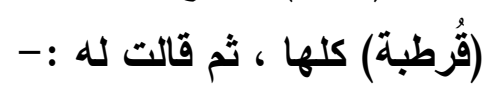

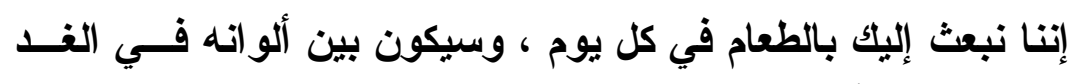

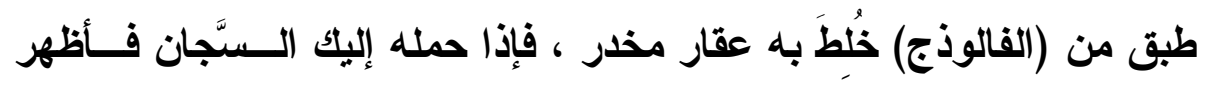

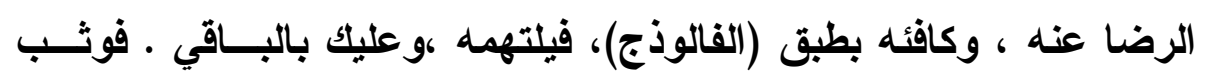

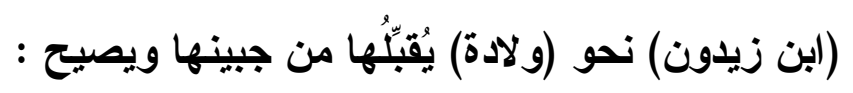

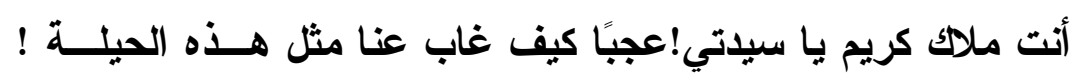

$$
\text { فالتفتت إليه (نائلة) وقالت :- أن كريات }
$$

و إذا تم خروجك من السجن سالمًا فاذهب إلى دار إن إبنة خالي ، وهي

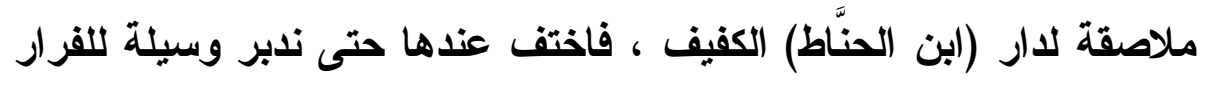

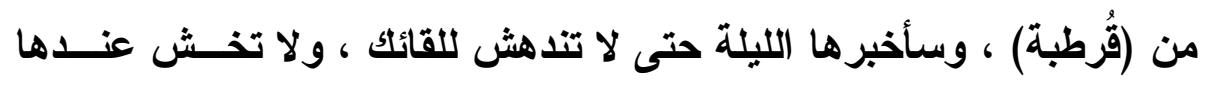

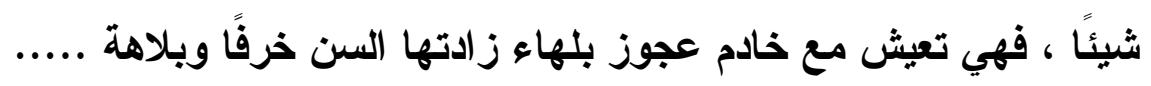

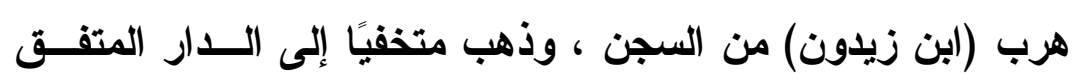

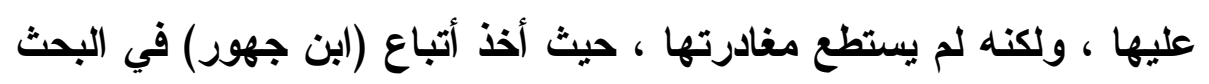




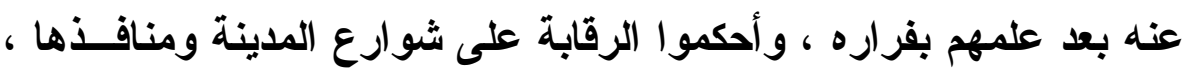
ومع مرور الوقت ، وكثرة البحث ، وانتثار الجواسيس ، توصل القوم إلى

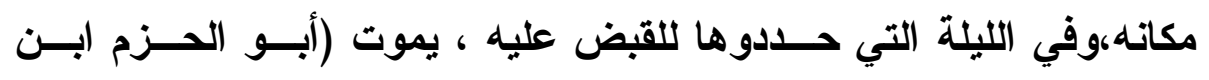

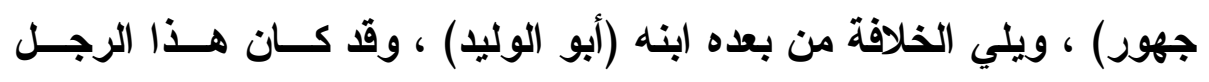

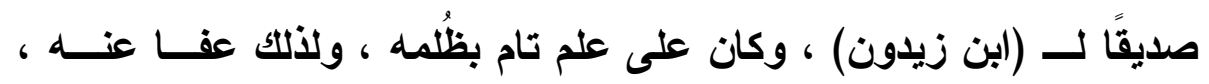

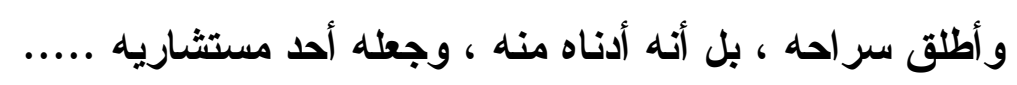

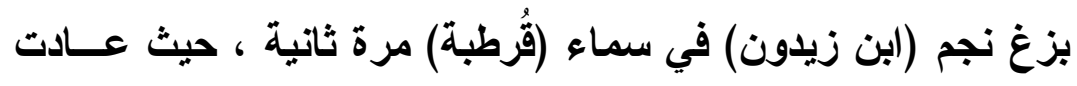

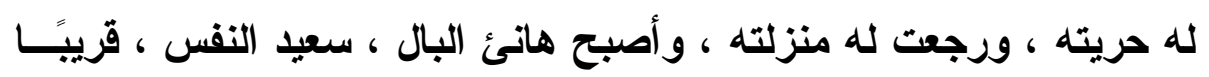

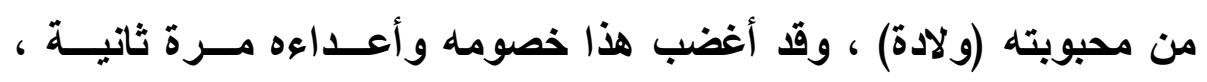

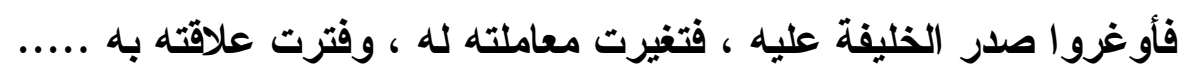

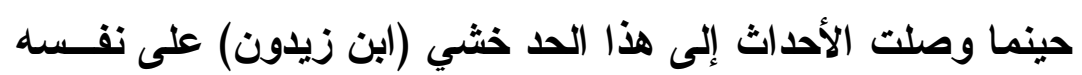

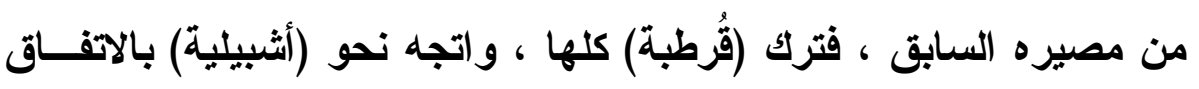

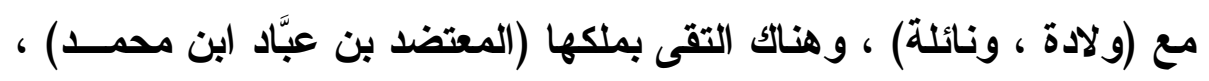

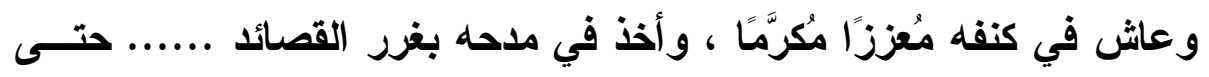

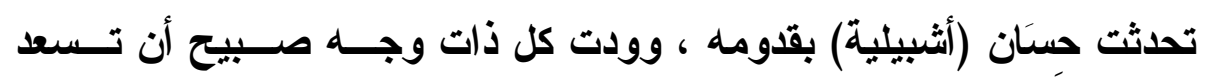

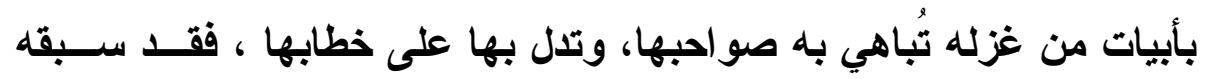

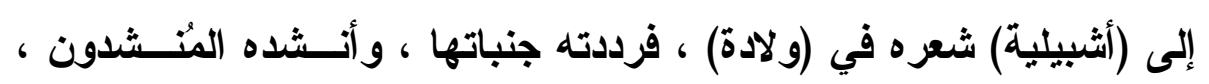
وغنَّى به المغتون ......

لم ينس (ابن زيدون) عهل (ولادة) ، ولم يزده تنائي الديار إلا شغفًا

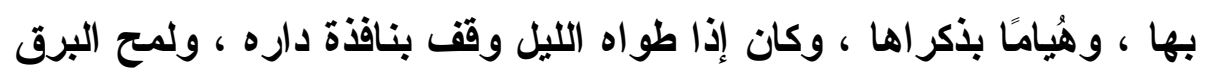

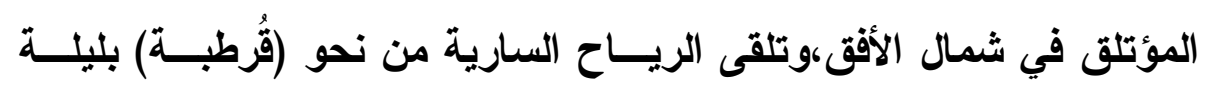

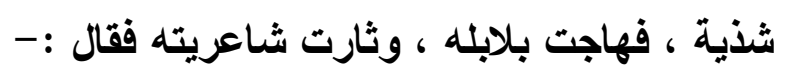

وَتَابَ عَنْ طِيبِ لُقَقِيَانَا تَجَافِينَا

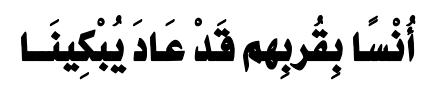

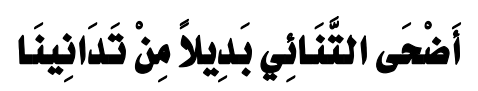

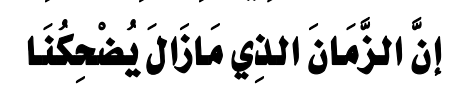




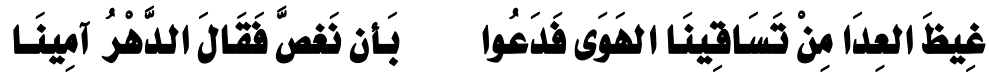

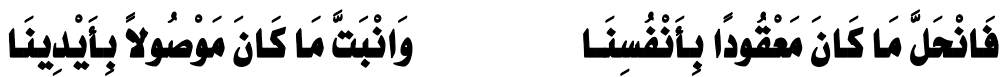

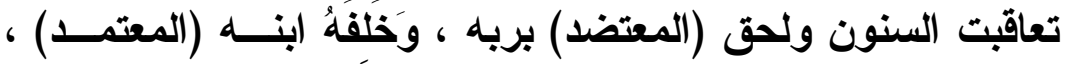

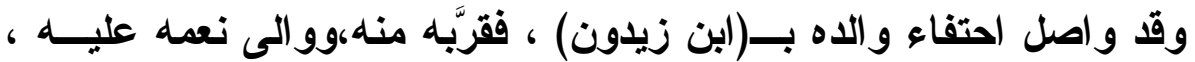

وجطله مستشاره الأول ، وشاعره الأكبر .......

فكر (ابن زيدون) في اغتنام الفرصة ، فحث الخليفة علـى إعــادة

دولة العرب ، وتجديد شبابها ، وإعادة مجدها ، قائلاً :-

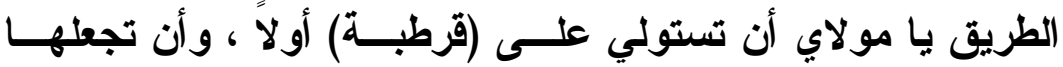

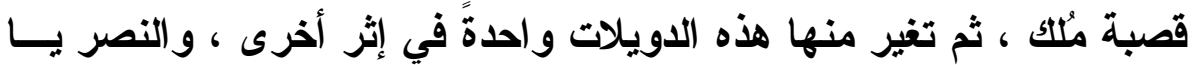

$$
\text { مولاي يجلب النصر ........... }
$$

اقتنع (المعتمد) برأي (ابن زيدون) ، وقام بإعداد جـيش جـرَّار لهــــه

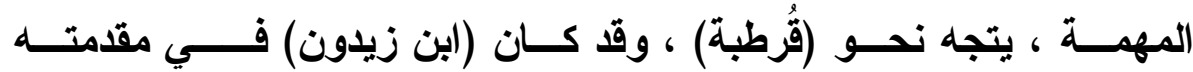

انتصر الجيش (الأثبيلي) ، ودخل (المعتمـــ) وأتباعـهـه المدينــة ،

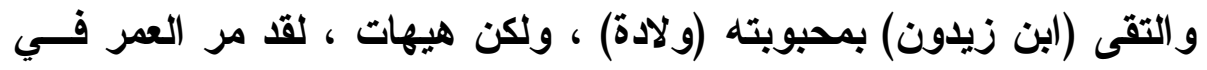

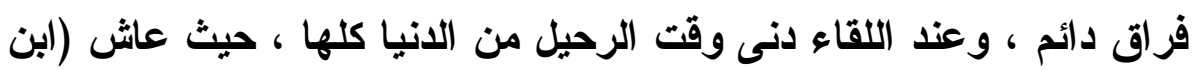

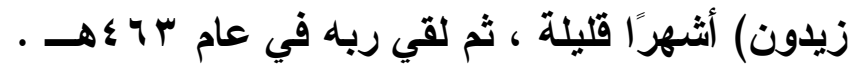

**** $\quad * * * * \quad * * * *$

\section{ب ـ الفكرة والهدف :-}

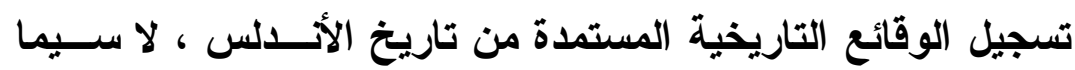

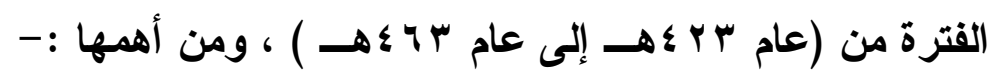

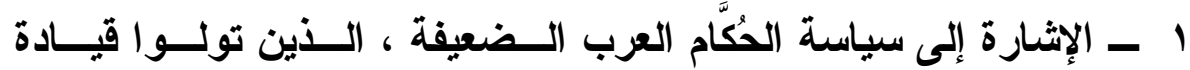

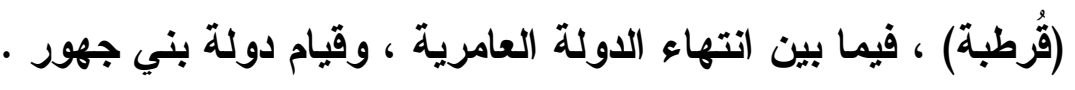

r - إبراز سياسة عميد الجماعة (أبي حزم بن جهور) في حكم (قرطبة) . 
r ـ تولي (ابن زيدون) شئون الوزارة في دولة (بني جهور) .

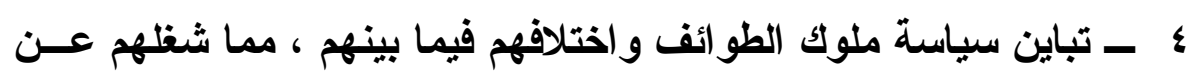

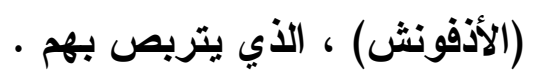

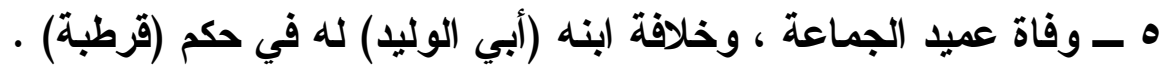
7 ـ الإثارة إلى سياسة (المعتضد عباد بن محمد) في حكم إمارة (أثبيلية)

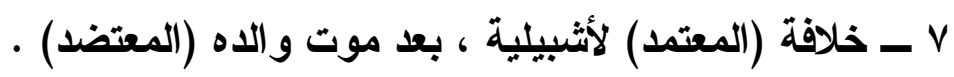

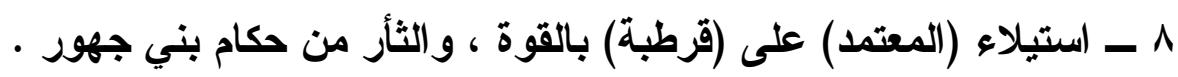
**** $\quad * * * * \quad * * * *$

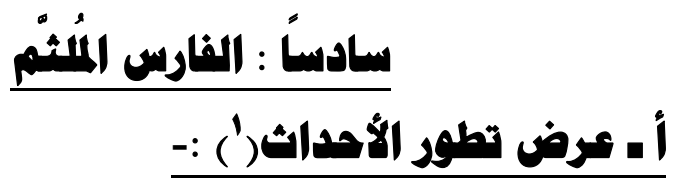

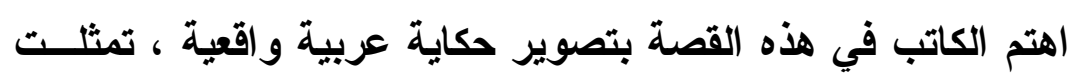

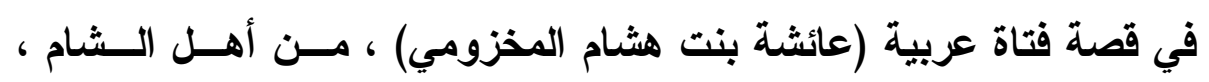

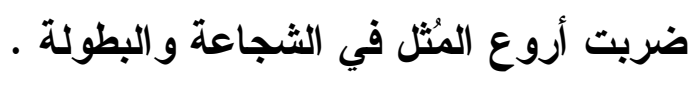

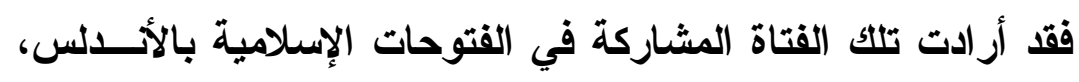

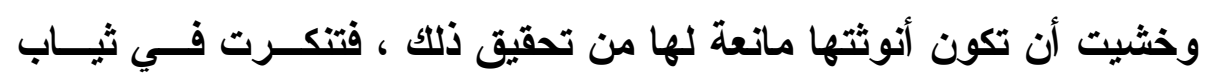

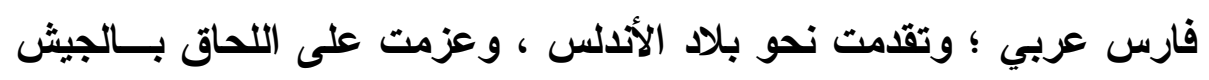

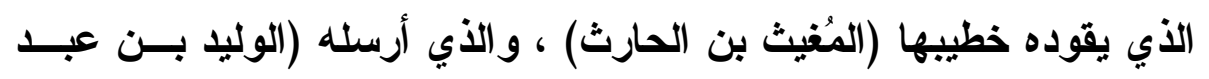

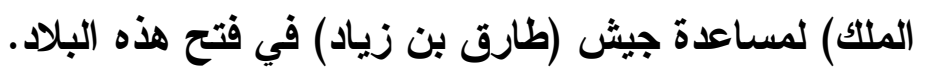

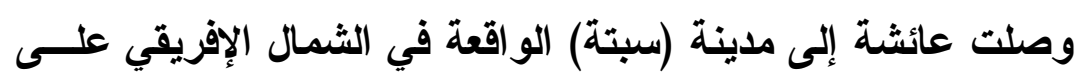

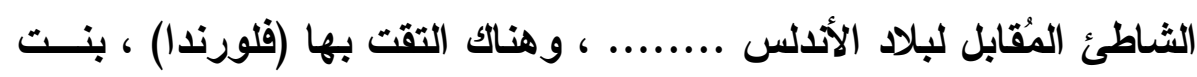
(يوليان) حاكم هذه المدينة السابق ، وقد أُعجبت بها تلك الفتاة المسسيحية

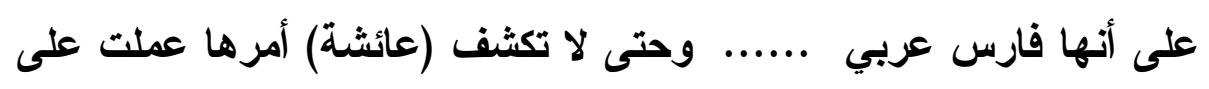

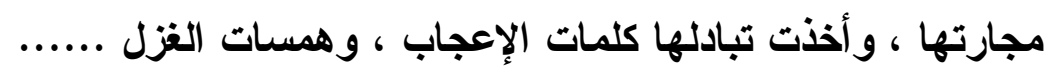

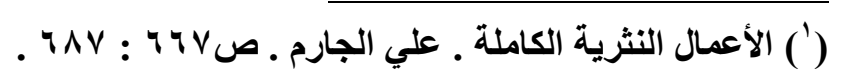
- H L - 
على أن إعجاب (فلورندا) هذا سرعان ما تحول إلى حب جـارف ؛

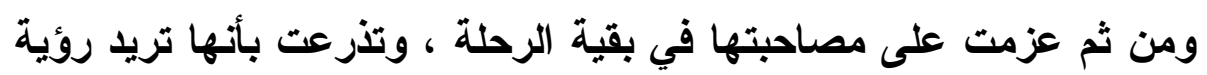
و الاها (يوليان) ، الذي صاحب جيش الفتوح في أعماق البلاد الأندلسية .

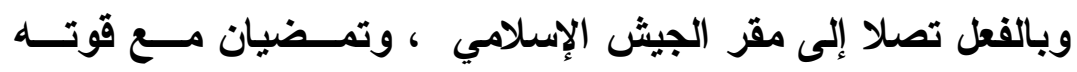

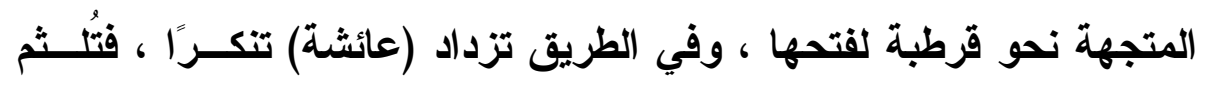
وجهها ، وتتحاثشى الاختلاط بالجند ......

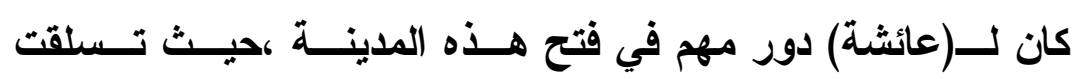

الأسوار العالية ، وفتحت بابها الرئيسي ، مما سهل من المهمة أمام الجيش ، الــــي

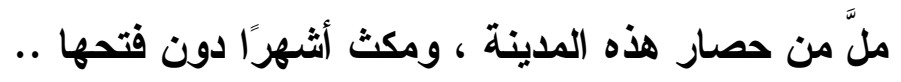

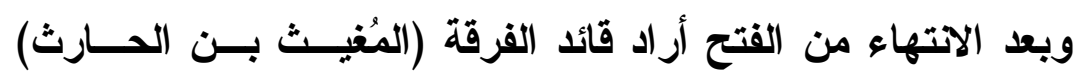

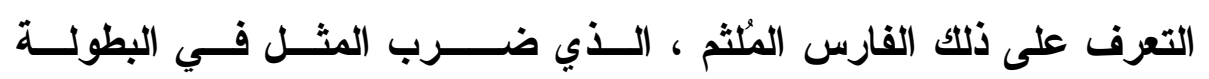

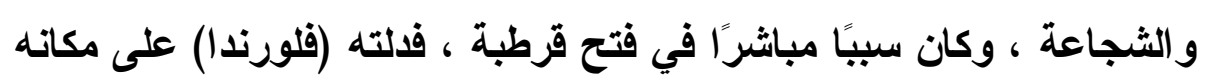

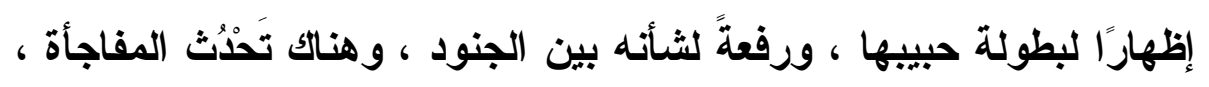

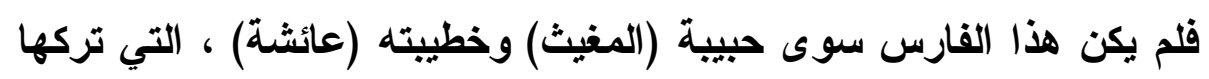

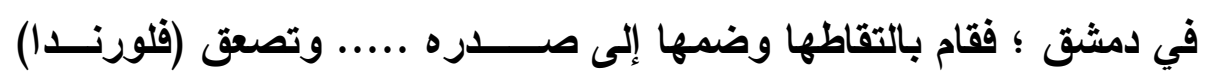
من هول الموقف وضياع حبها .....

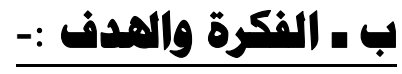

قََّّم الجارم في هذه القصة صورًا من الوقائع التاريخية الحقيقية في

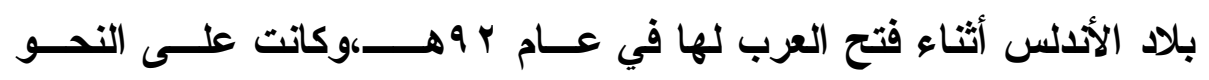
التالي:- 
1

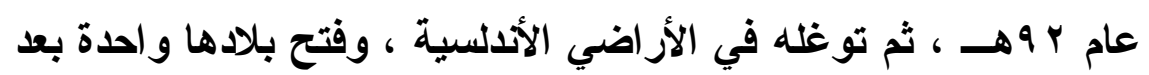
الأُخرى . أبام

r ـ انتصار الجيش العربي على جيش (لذريق) المسيحي ، فـــي موقعـة

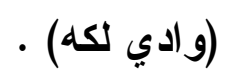

r - م أسباب مساعدة (يوليان) حاكم مدينة (سبتة) لــ (طارق ابن زياد) في

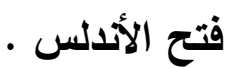
؛ ـ الأحداث التي و اكبت فتح الجيش العربي (قرطبة) ، بقيادة (المغيث بن

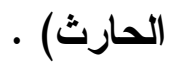

$$
\text { **** } * * * * * \quad * * * *
$$

\section{سابعاً : هرع الوليد}

\section{أ أ عرض تطور الأمداث(') :-}

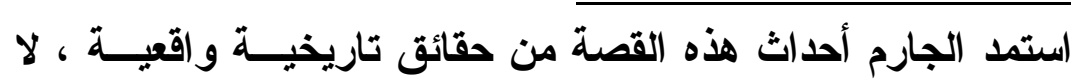

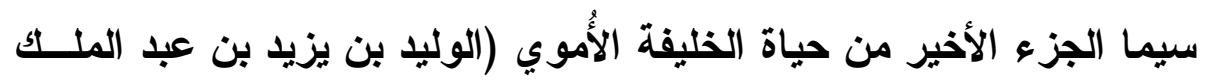

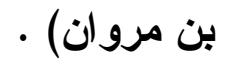

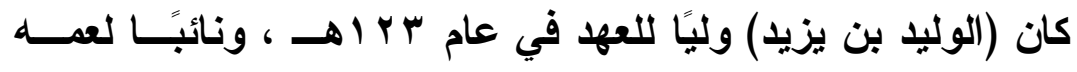

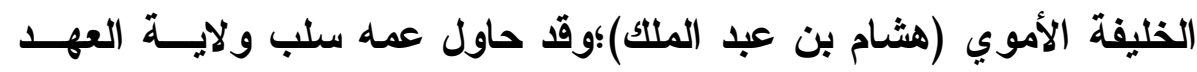

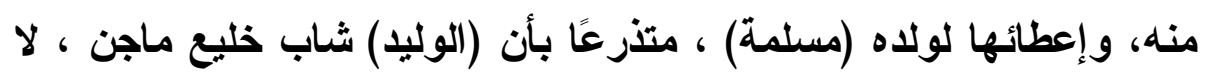

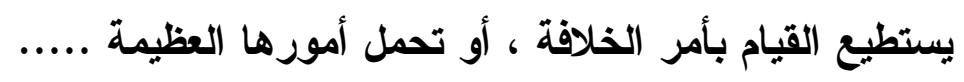

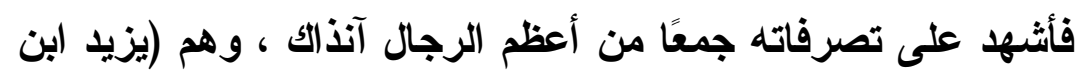
الوليد ، ويزيد بن عنبسة ، ومحمد بن شهاب الزهري ، ويزيد الـسلدي) ؛

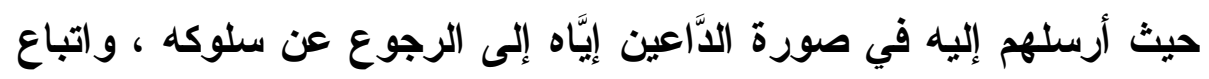
الخُلق القويم ، تمهيدًا لتولي أمر الخلافة صورة ألهاه

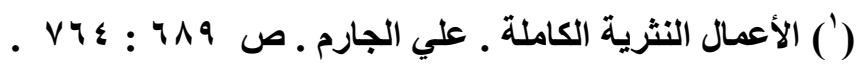




$$
\text { ومما قاله (الزهزي) لـ (لوليد) :- }
$$

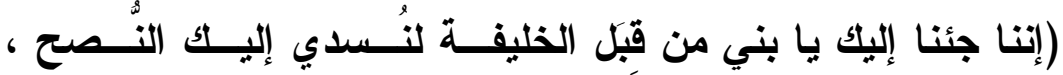

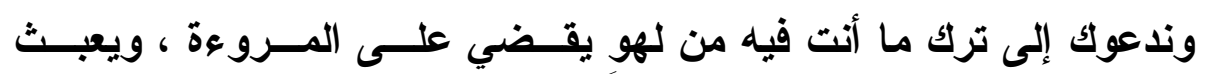

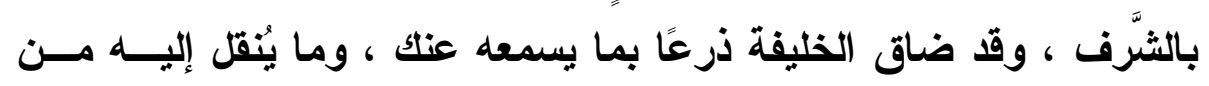

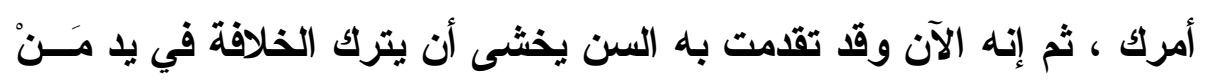
لا يصونها ، أو يستطيع النفح دونها) .

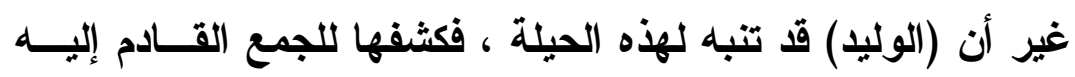

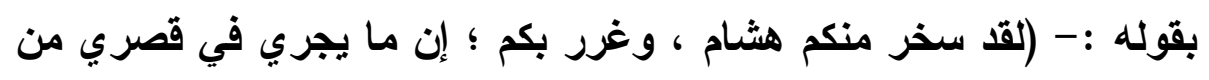

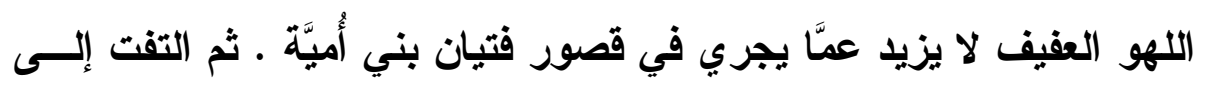

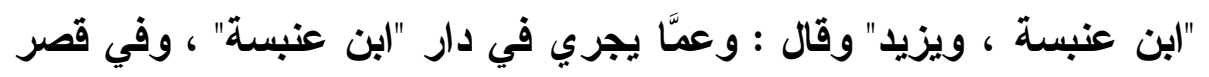

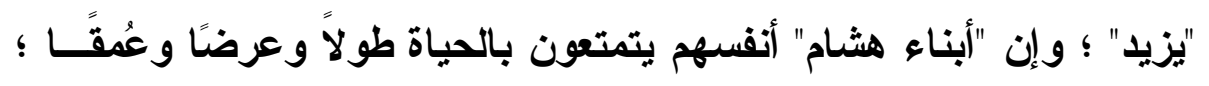

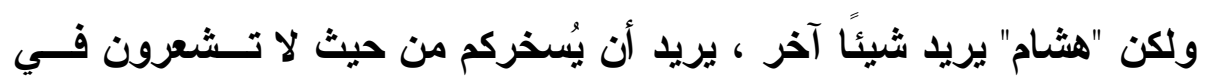

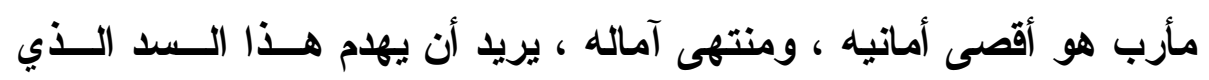

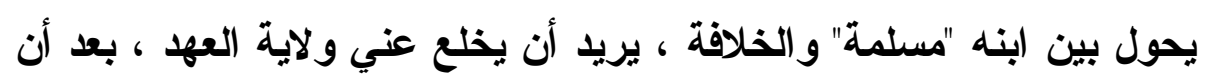

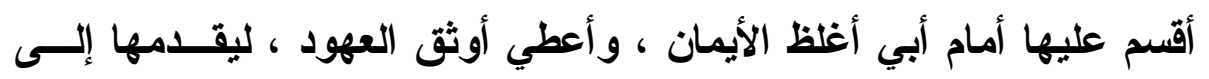
"أبي شاكر" هاية غالية ثمينة تبقى في أولاده وأحفاده أبد الدهر) .

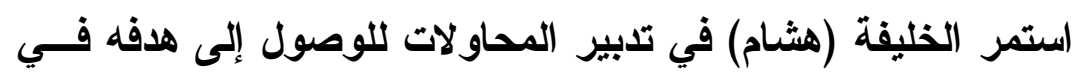

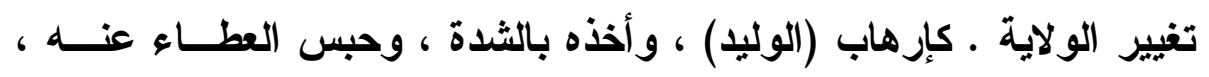

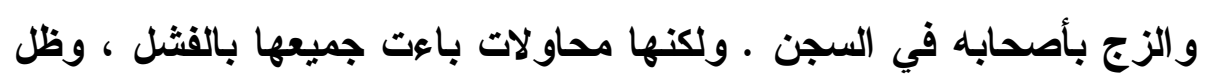

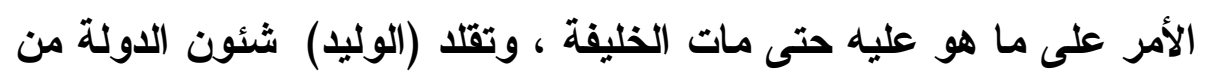
نشط الخليفة الجديد في أول عهده في البذل والعطاء ، و أكثـر مـن

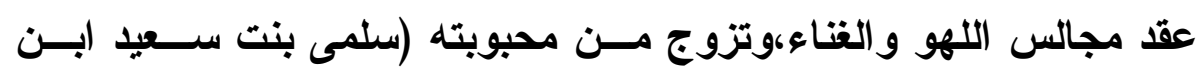

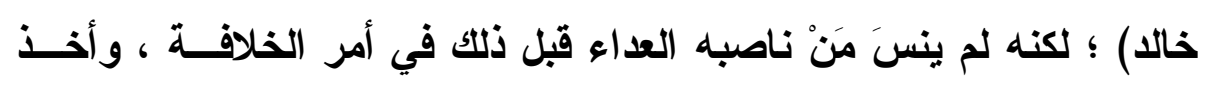


ينكل بهم ، ومرت شهور و(الوليد) يشفي نفسه في كل يوم بانتقام جليـــ ، حتى خافته خاصة الناس وعامتهم ؛ ولقد فرح الناس لتوليته أول الأمر لمَّا

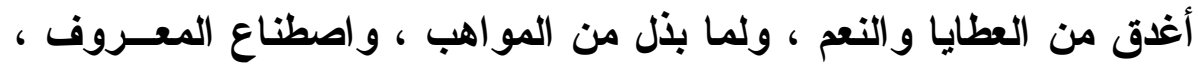

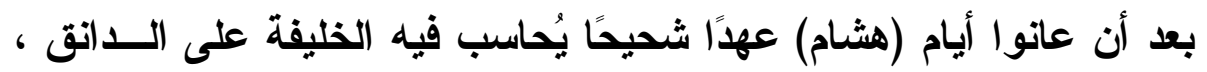
ولا يثيب إلا على عمل ....

ولكن الوليد لم يستطع أن يمد يده بالعطاء في كل حين ، ولم يكـن

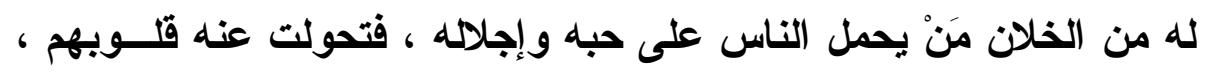
ونالت منه ألسنتهم ...

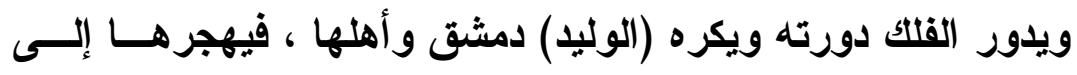

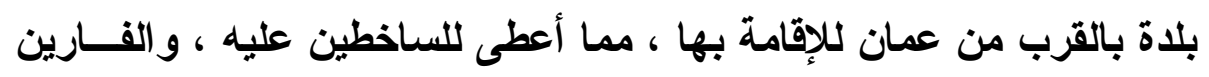

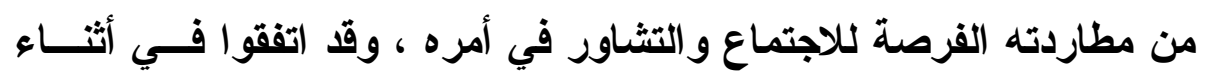

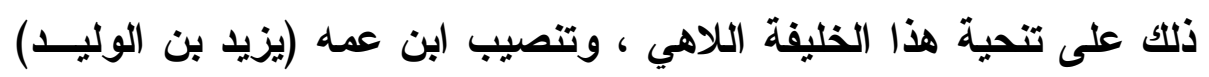

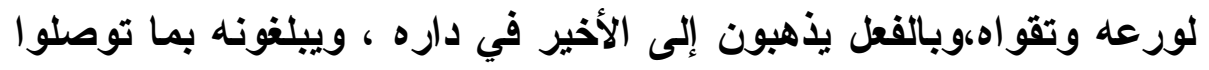

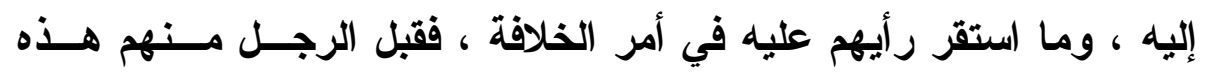

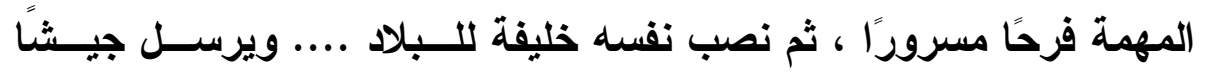

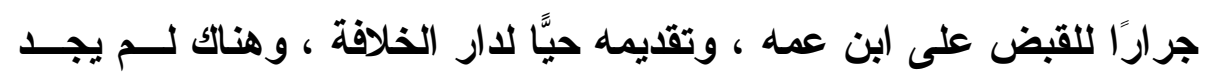

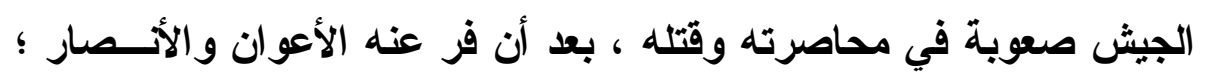

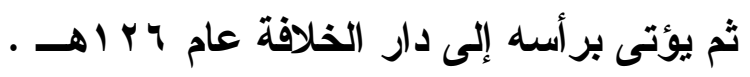
********* $*$ *

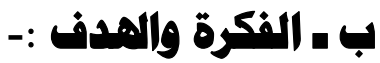

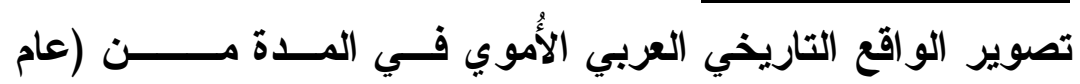

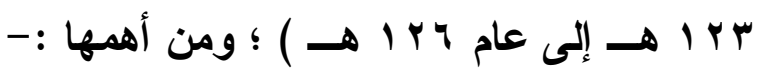
1 ـ سياسة الخليفة الأُموي (هثام بن عبد الملك) في أُخريات أيَّامه 
r ـ محاولة خلع ولاية العهـ من ابن أخيه (الوليد بن يزيـــ) ، و إقرارهــا

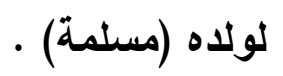

r ـ سلب أموال العراقيين على يد الو الي (خالد بن عبد الله القسري) ـ

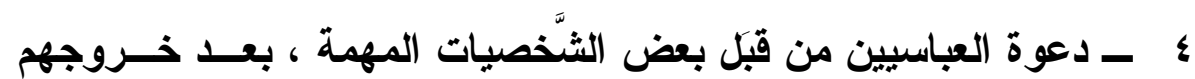

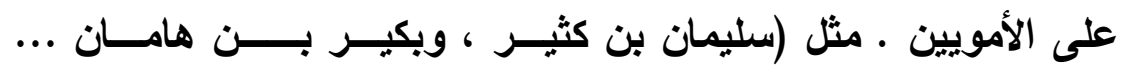

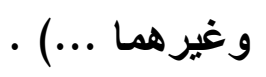

ه ـ الدور الفارسي في الدعوة إلى العباسيين،وأهم شخصياته . .

T- تولي (الوليد بن يزيد) الخلافة بعد موت الخليفة (هشام بن عبد الملك)

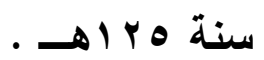

V - سيطرة (يزيد بن الوليد) على الخلافة ، بعد مقتل (الوليد ابـن يزيـــــ

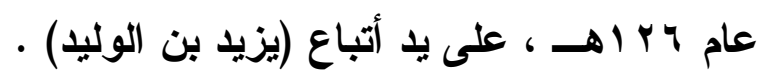

*** $\quad * * * * \quad * * * *$

\section{ثامنًا :سيدة القصمر}

\section{أ. عرض تطور الأهد|ث(') :-}

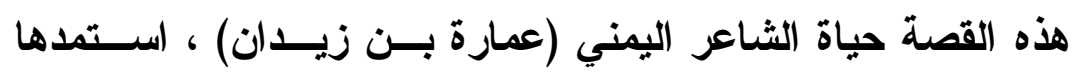

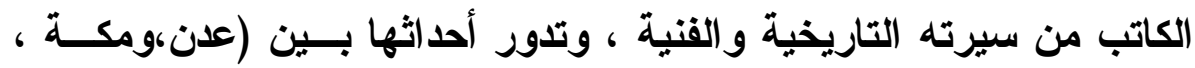

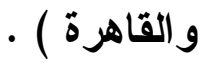

فقد ترك (عمارة بن زيدان) مدينة (زُبيد) ، متوجهًا إلى (مكة) هربًا

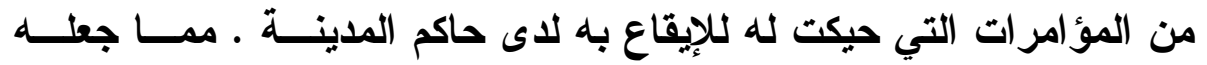
يُسرع إلى داره ، ويجمع متاعه ، وما بقي لايه من مال قليل ؛ وأعد لأهله

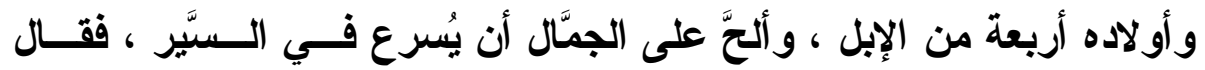

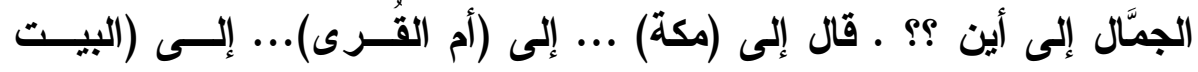

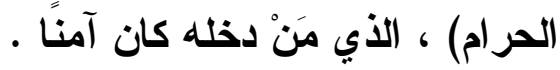

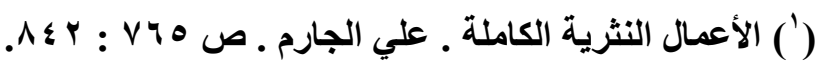




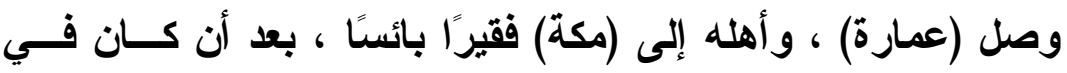

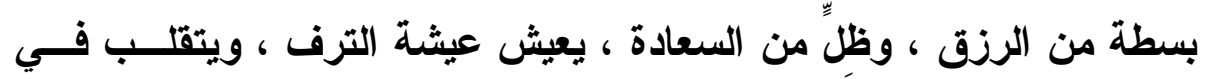

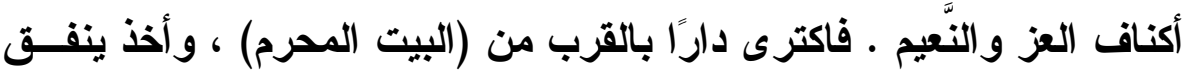

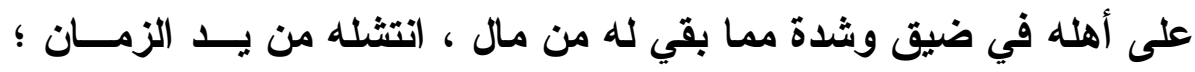

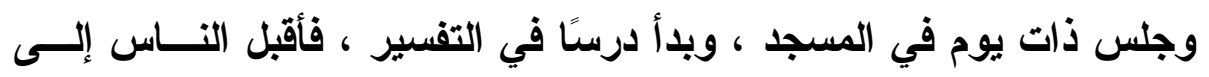

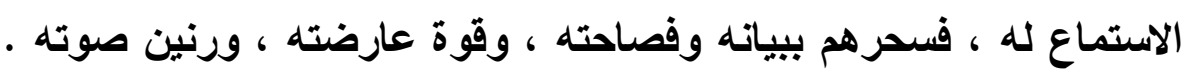

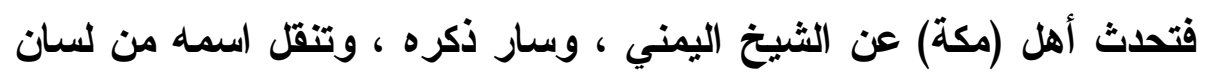

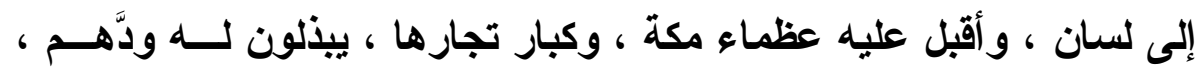

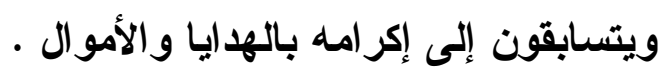

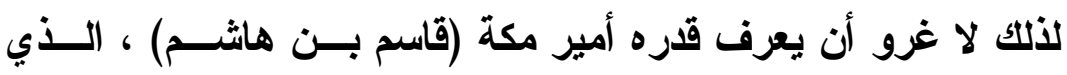

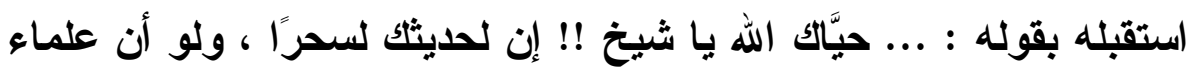

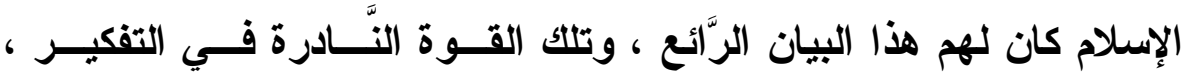

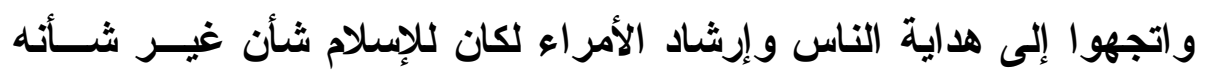
اليوم الئ

و انتهز الأمير الفرصة ، وطلب منه الذهاب إلى (ســيدة القـصور)

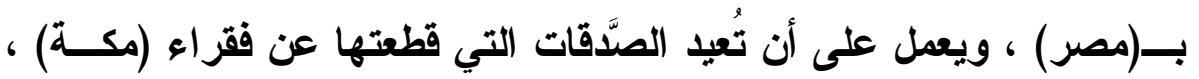

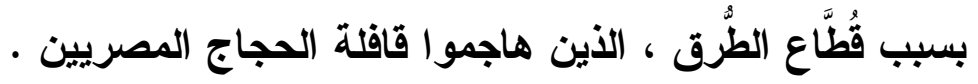

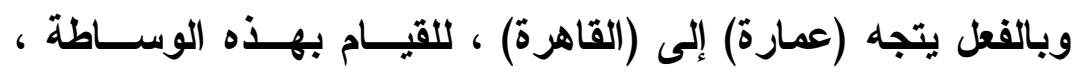

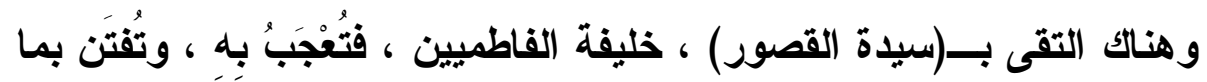
لايه من صفات العلماء في جل المجالات العلمية ، خاصة علوم الدين ، و الثعر وفنونه . .

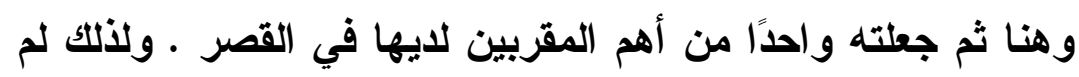

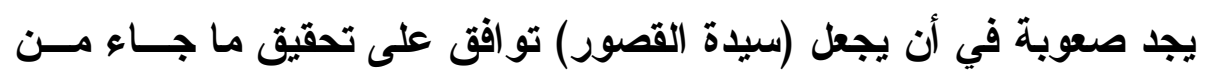
أجله. 
و أقام (عمارة) بالقاهرة طويلاً في هدوء بــال ، وكســان يستـاعيه

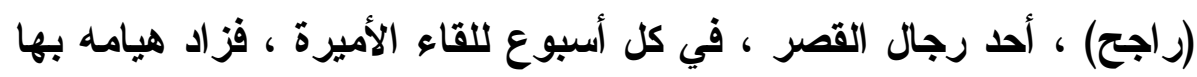

ويجودها وذكائها وحرصها على حياطة الدولة .

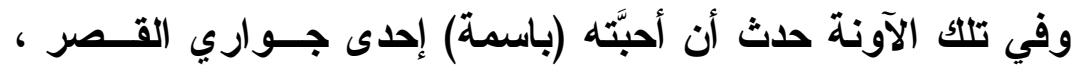

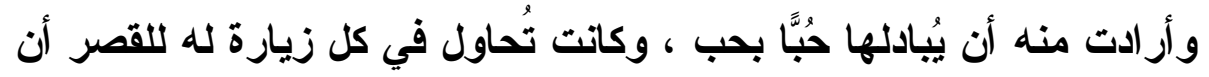

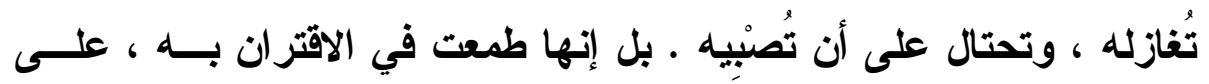

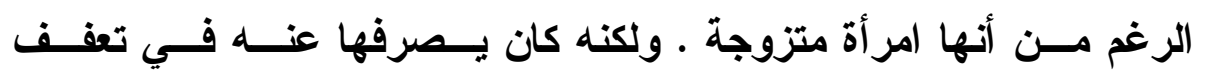

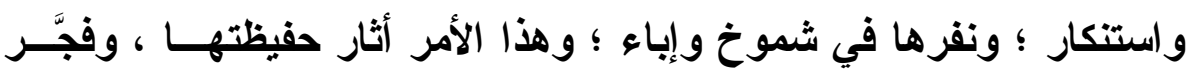
غضبها ـ حتى قالت له : الهن

أعزئب عنك بعد أن كثفتُ لكك عن ذات نفسي ، وفضحتُ لكك خبئسـة

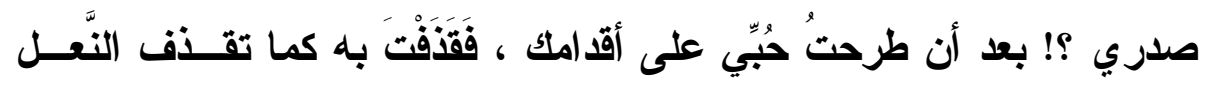

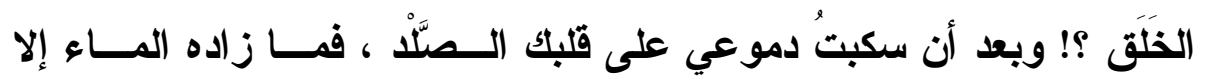

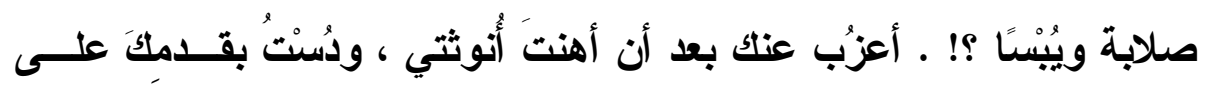

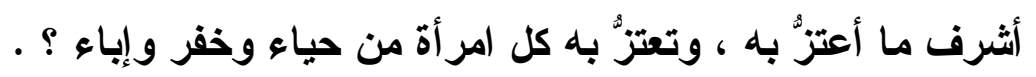

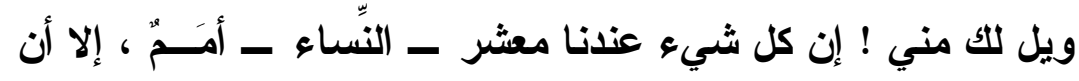

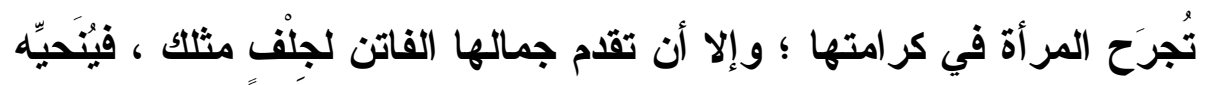

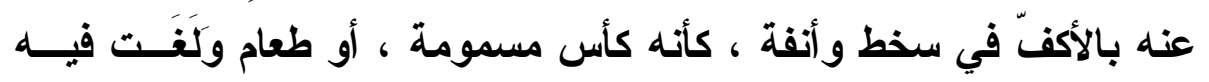

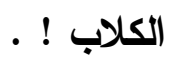

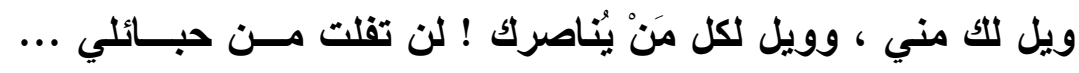

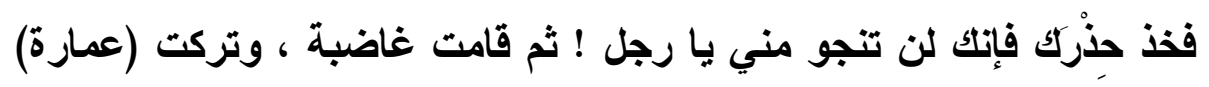
في ذهول وعجب ... ومن ثم دست له عند فئ (سيدة القصور) للإيقاع بهاء فتم

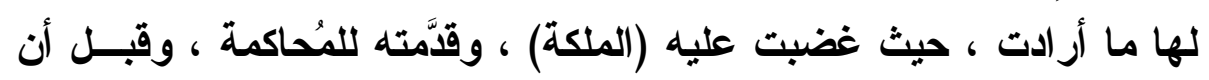

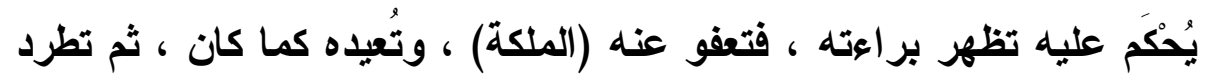
الجارية جزاء كذبها وخياتتها . 
وردًا على ذلك أخذت الجارية في العمل على تقويض أركان الدولــة

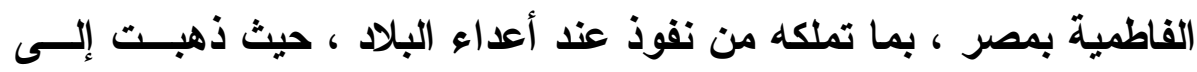

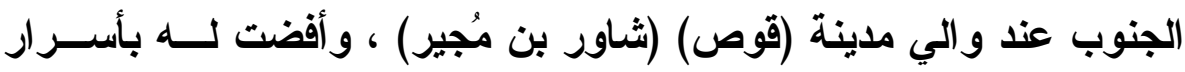

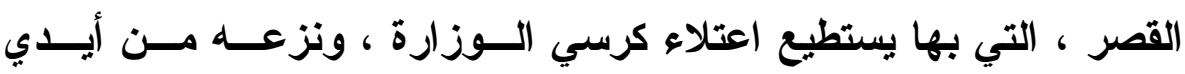
الضعفاء من وزارة (سيدة القصور) .

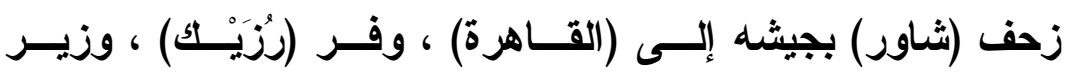

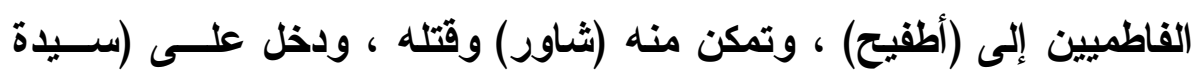

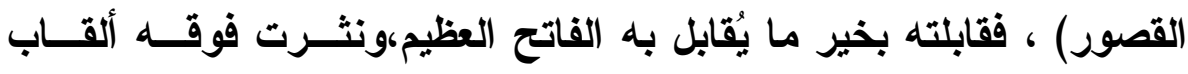

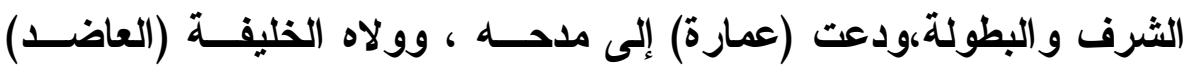

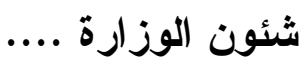

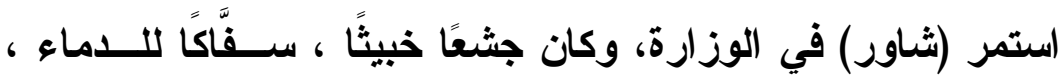

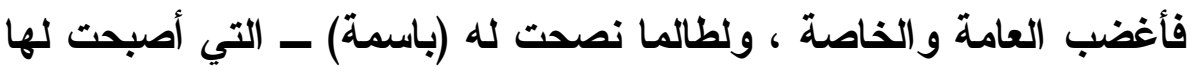

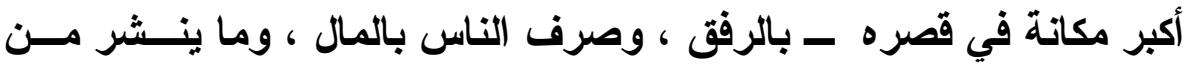

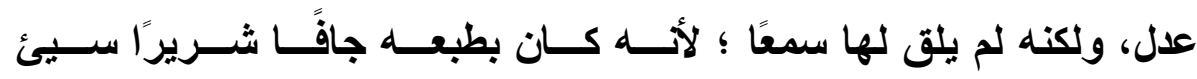

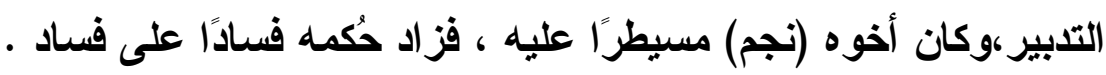

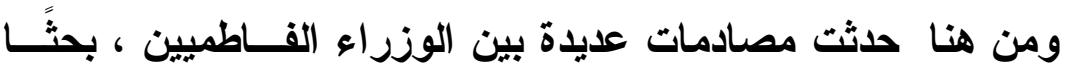

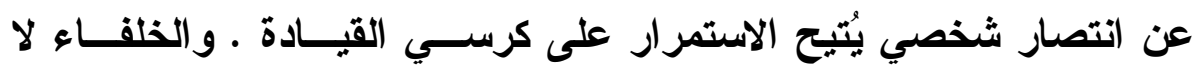

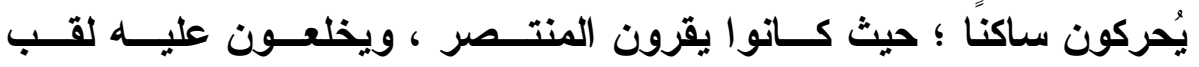

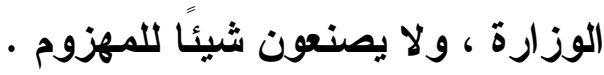

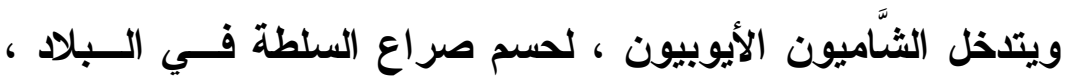

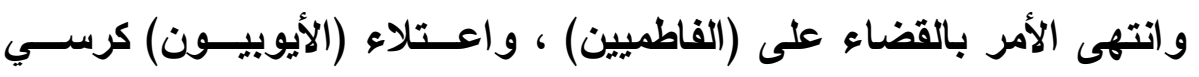

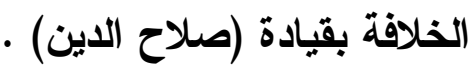

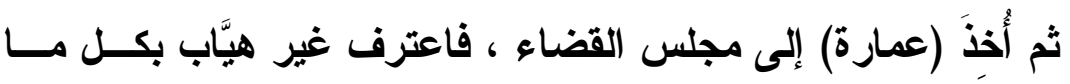

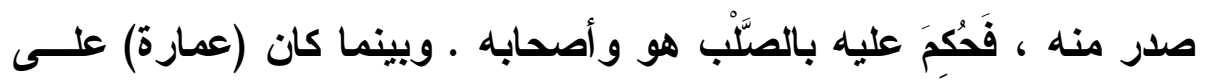


خثبة الموت ، مرَّت جنازة يمشي خلفها فقراء القاهرة وعسامتهم بـاكين

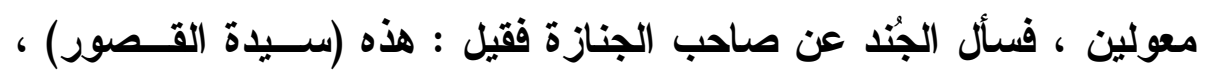

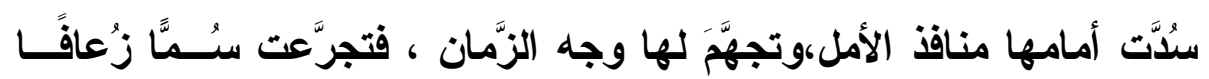
ماتت به لساعتها . ماعل

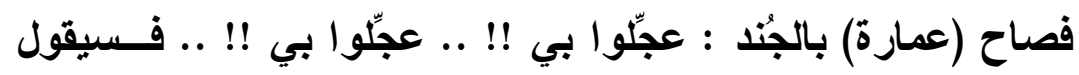

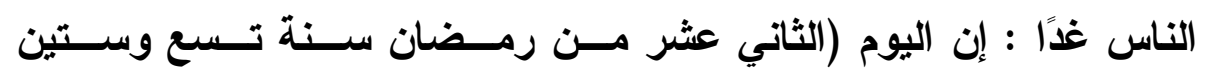

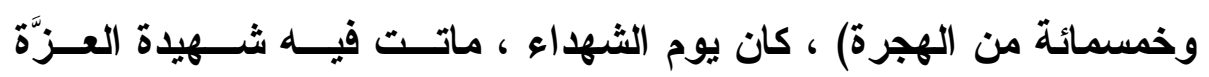

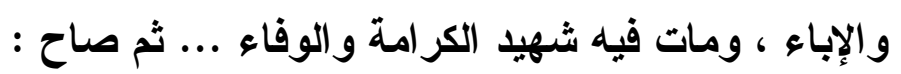

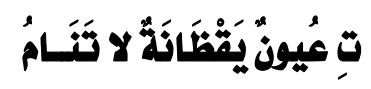

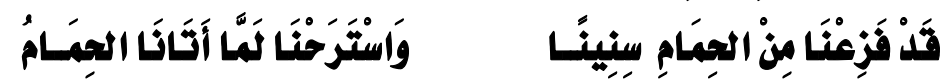

\section{بـ - الفكرة والهدف :-}

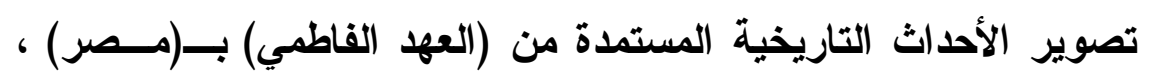

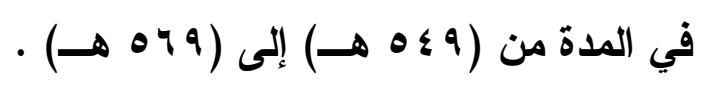

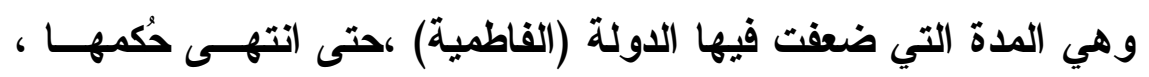

وقامت على أنقاضها الاولة (الأيوبية) .

ومن أهمها تصوير الأحداث التالية :- الايوبة -

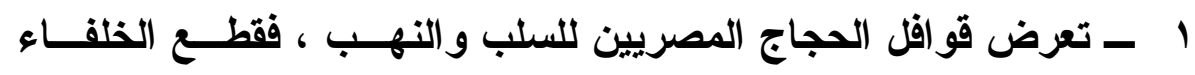

$$
\text { (الفاطميين) الصدقات عن فقراء (مكة) . }
$$

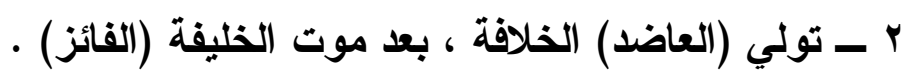

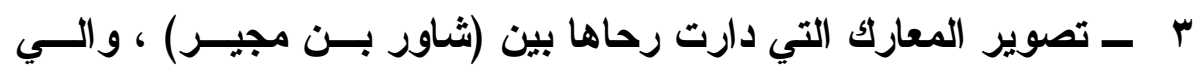

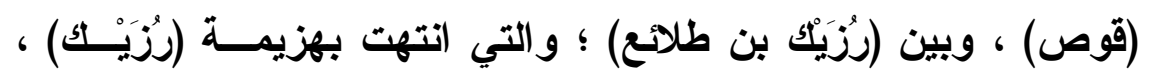


؛ ـ تصوير المعارك التي دارت رحاها بين (ثشاور بـن مجيـر) ، وبـين

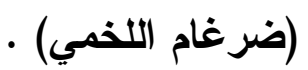

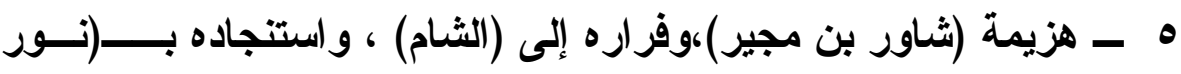

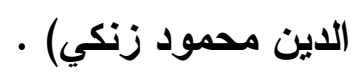

4 - حضور الجيش (الأيوبي) إلى (القاهرة) ، بقيادة (أسد الدين شيركوه ،

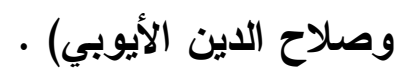

V - حضور جيش الإفرنج إلى (القاهرة) ، بدعوة من (شــاور) ، لإخــراج

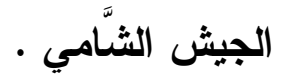

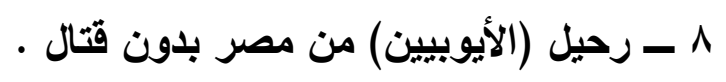

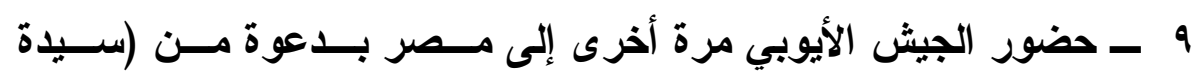

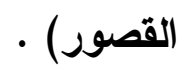

. 1 ـ المعارك التي دارت رحاها بين جيش الأيوبيين ، وجيش الإفــرنج ،

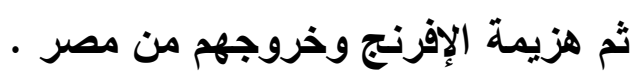
11 ـ قيام الدولة (الأيوبية) ، على أنقاض الاولة (الفاطمية) . **** $\quad$ ***** $*$ * $* * *$

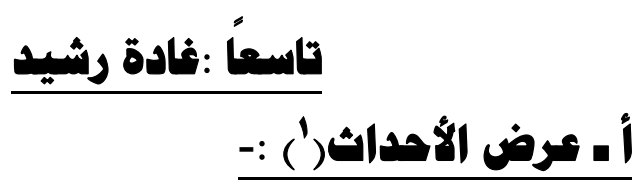

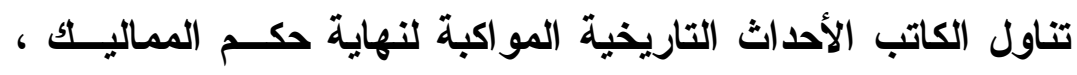

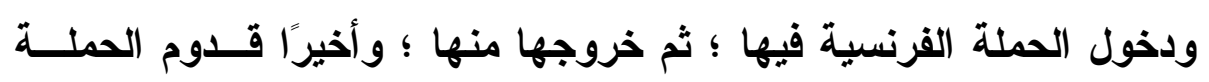

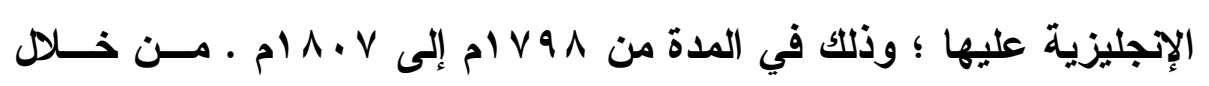

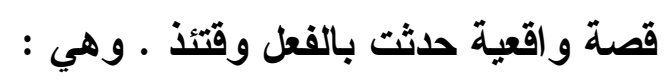

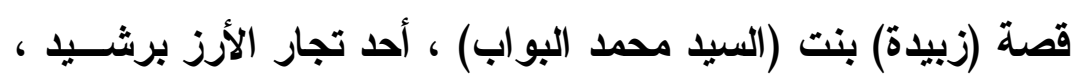

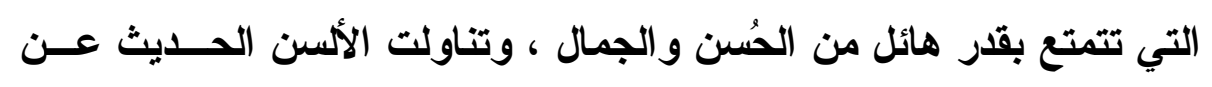

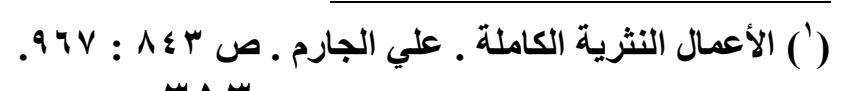

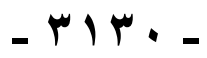




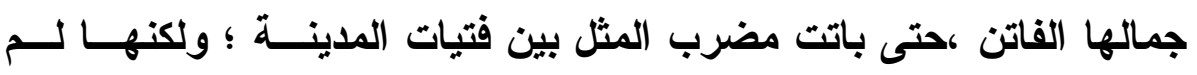

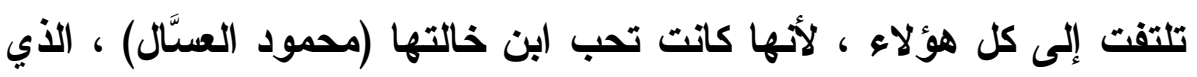

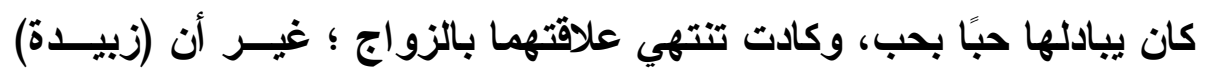

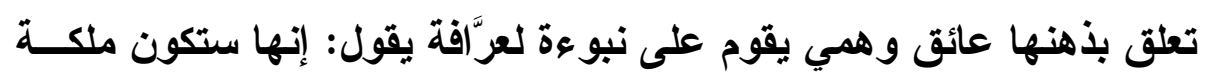

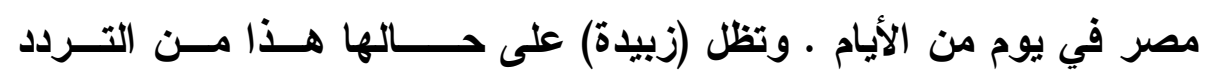

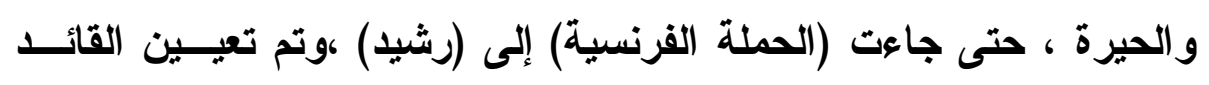

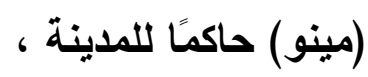

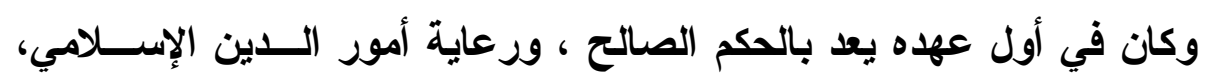

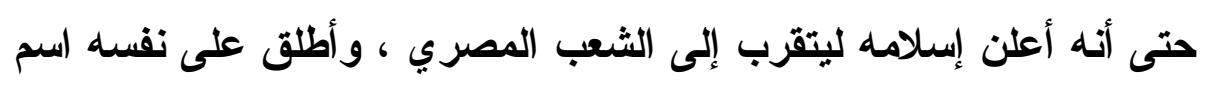

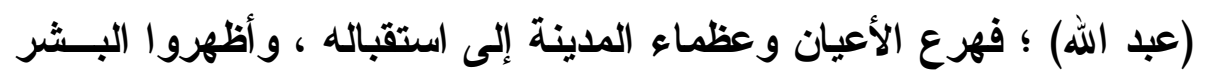

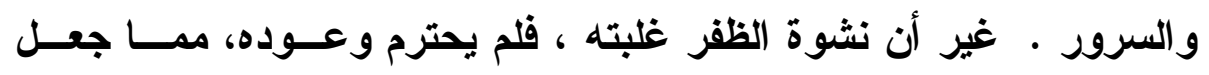

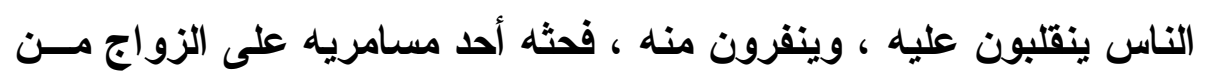

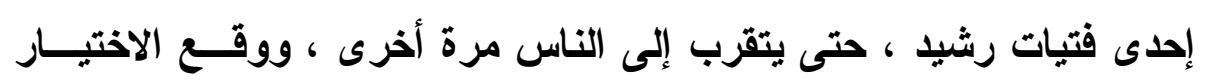

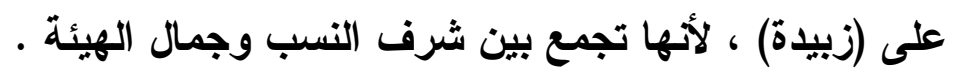
وبالفعل تزوج (مينو) من (زبيدة) ، التي رأت في إتمام هذا الزواج النياج

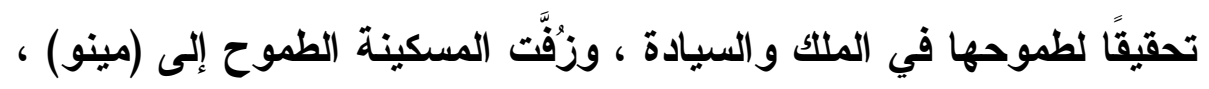

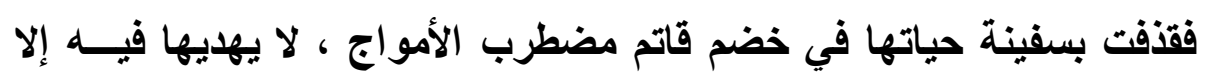

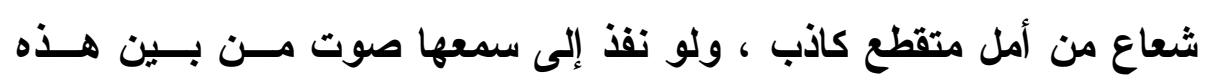

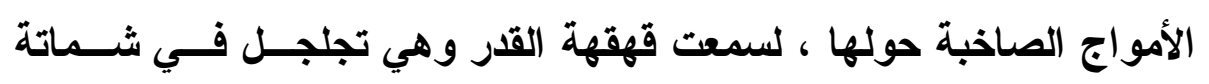
وسخرية .

فقد لقيت (زبيدة) من زوجها (مينو) أول الأمر شغفًا وهُيامًا وطُرقًا

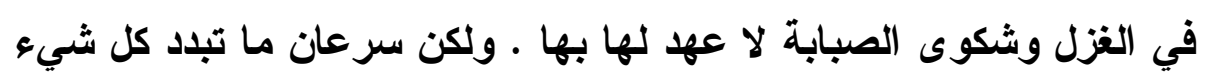

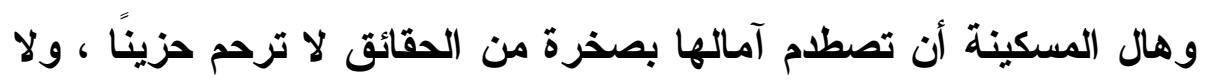
تو تواسي بائسًا . 


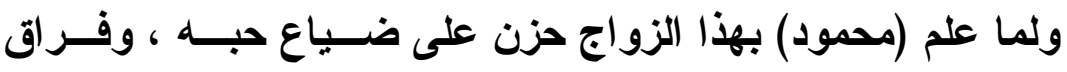

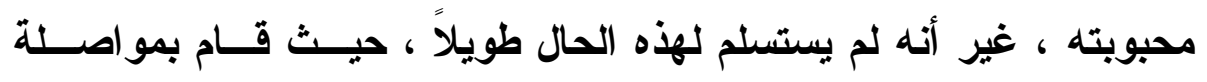

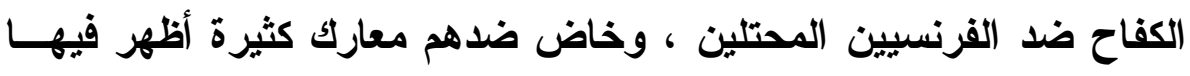

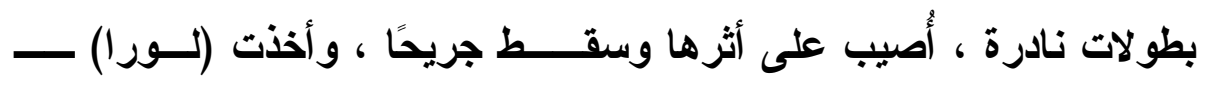

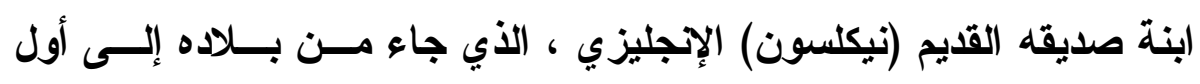

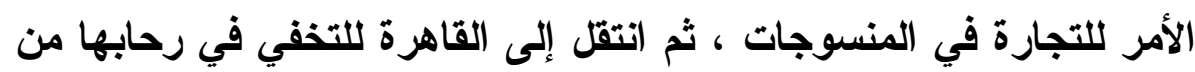

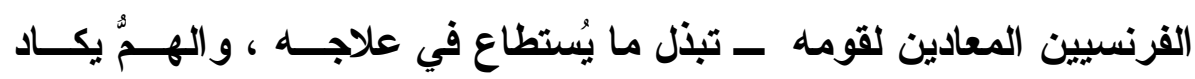

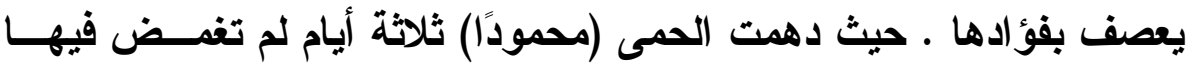

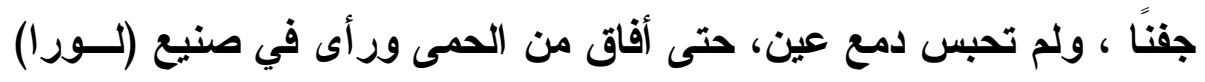

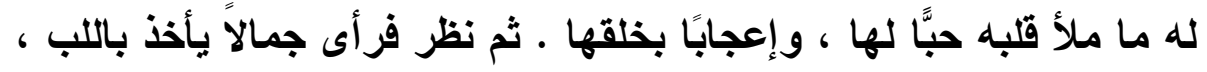

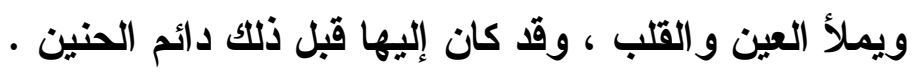

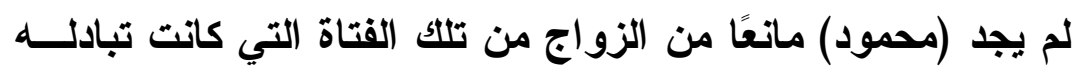

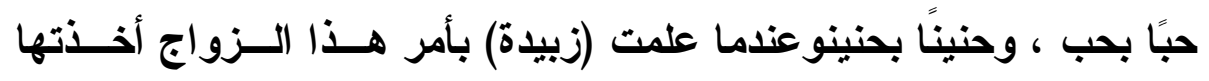

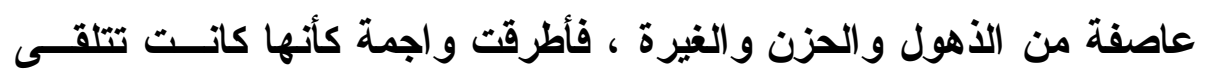

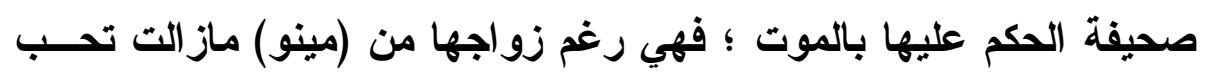

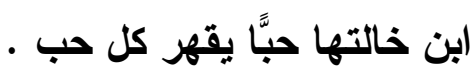
وأخيرًا تبينت (زبيدة) الحقيقة المُرَّة ، فلم تصل إلى ما كانت تطمح

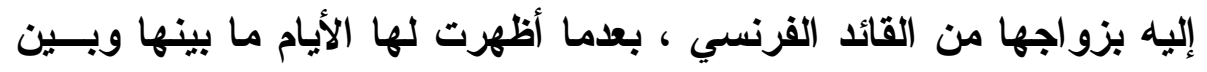

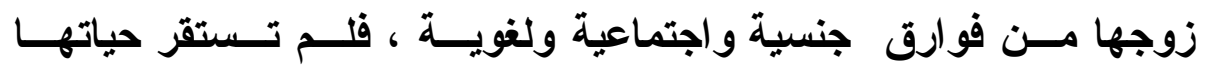

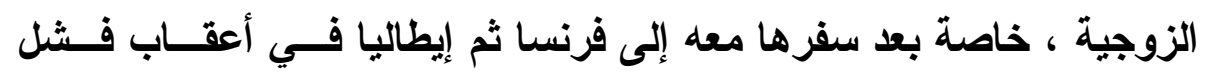

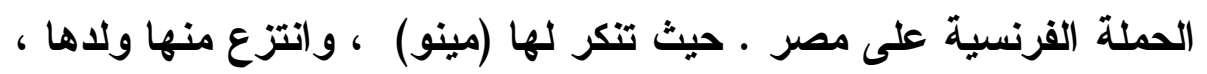

$$
\text { وضيق عليها . }
$$

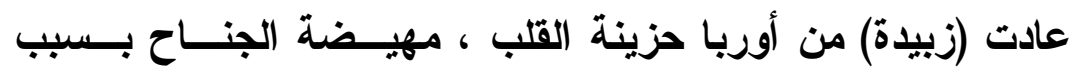

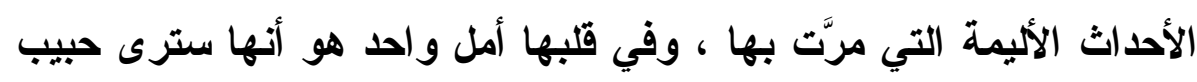


الوجدان الأول (محمود العسال) ؛ لكن وا أسفاه عادت فوجدته قد استـشهر

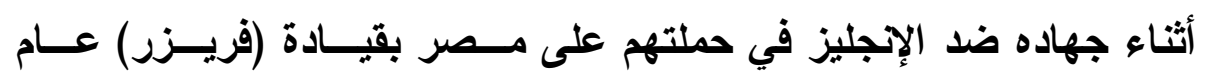

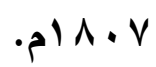

فانطلقت مسرعة نحو قبره حتى إذا بلغته رأته امر أة جاثيـــة عنـــــ

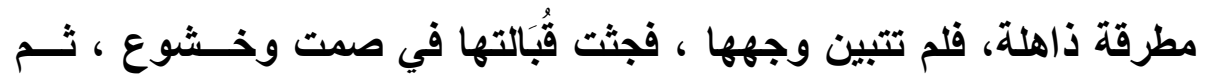

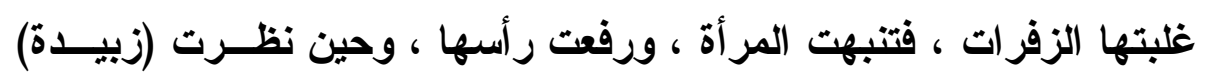

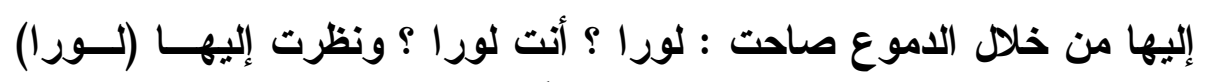

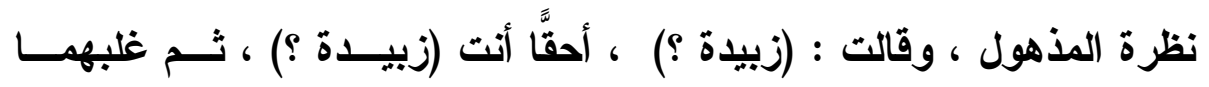

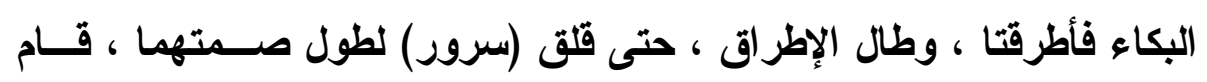

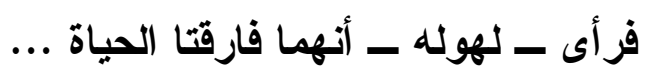

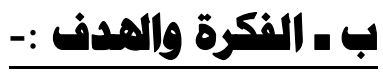

اهتم الكاتب في هذه القصة بتصوير الأحداث التاريخية التي مسرت

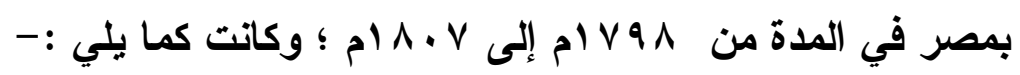

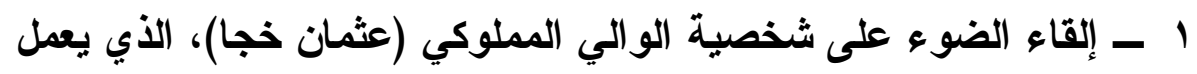

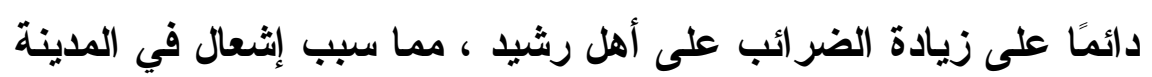

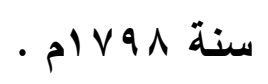

r ـ ـخول (نابليون) ، قائد الحملة الفرنـسية إلــى مـصر عـن طريــق

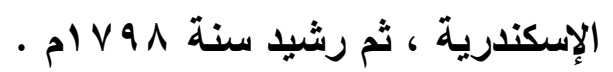

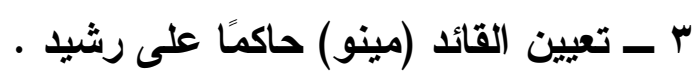

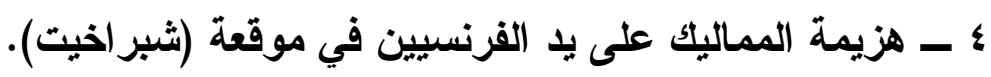

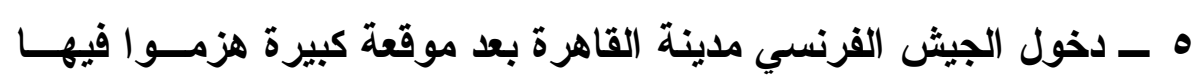
المماليك . لمول

7 - هزيمة الأسطول الفرنسي في موقعة (أبي قير) البحرية . 


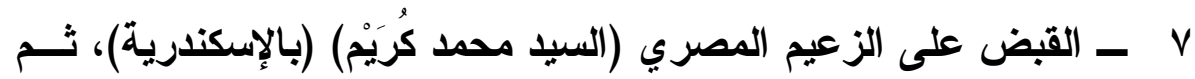
حمله إلى (القاهرة) لتنفيذ حم الإعدام عليه .

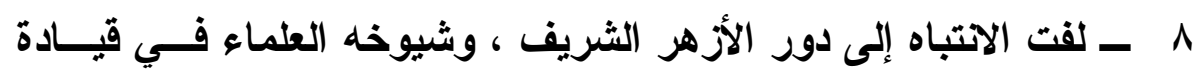

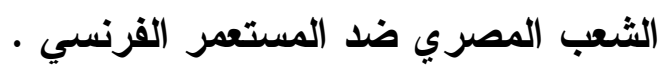

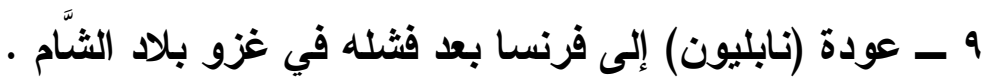

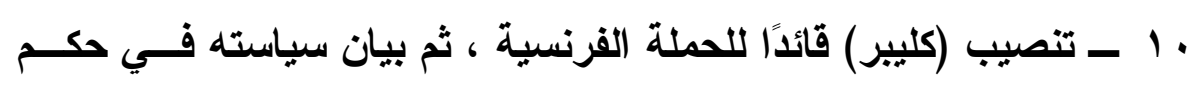
البلاد بعد توليه الأمور - البير)

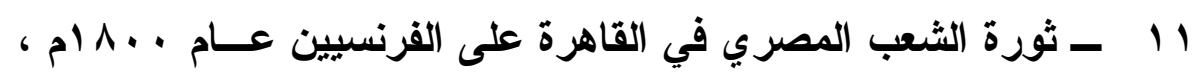

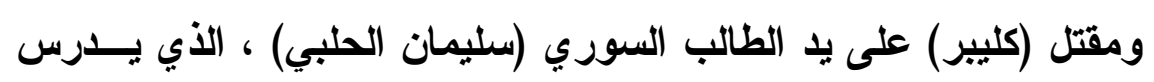

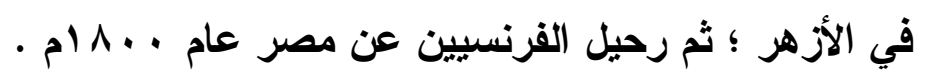

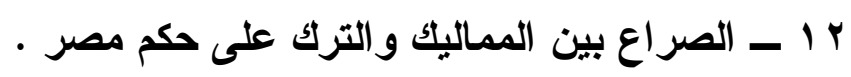

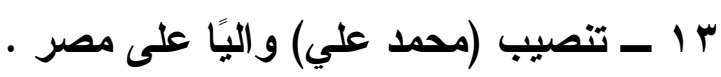

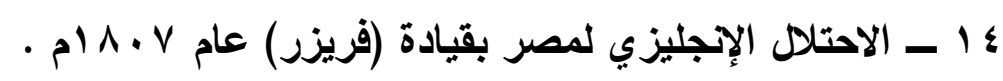
10 **** $\quad$ ***** $* * * * *$ 


\section{القفسم الثاني}

أولاً : تكوين الأحداث. توطئة:-

لا غرو في أن القصة التاريخية مستمدة من وقائع مرحلة تاريخيــة

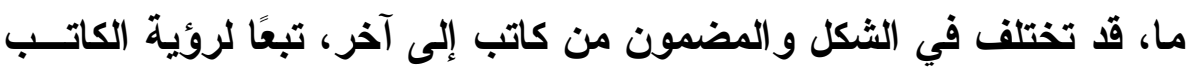

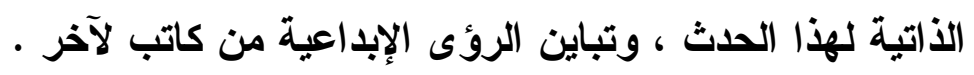

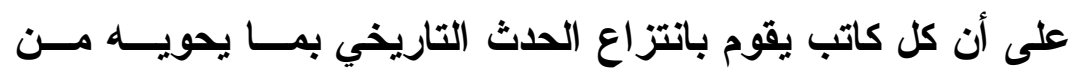

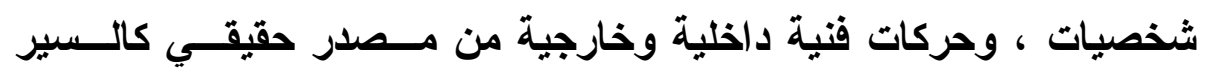

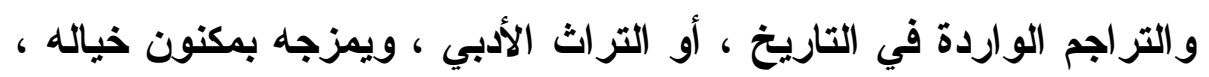
حتى يلتقطه عقله وييتكره من تلقاء نفسه .

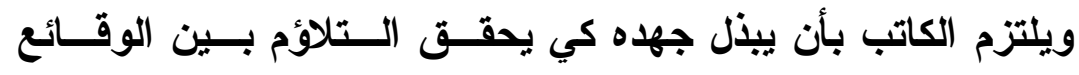

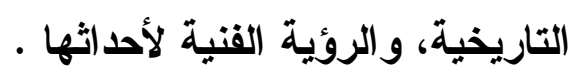

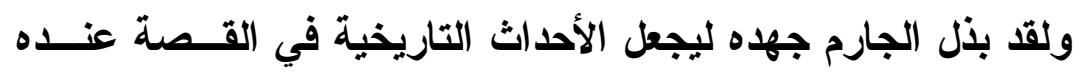

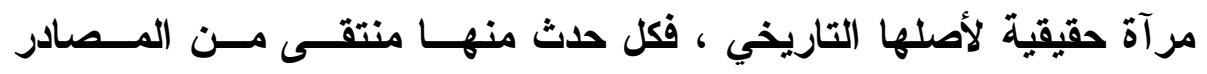

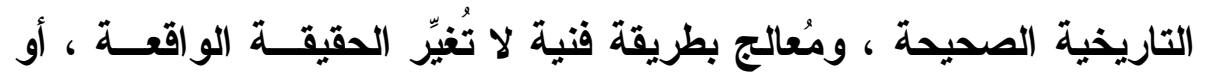

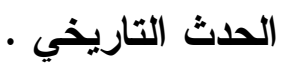
فحينما نُقارن الأحداث في القصة التاريخية عنده بأصلها التاريخي ،

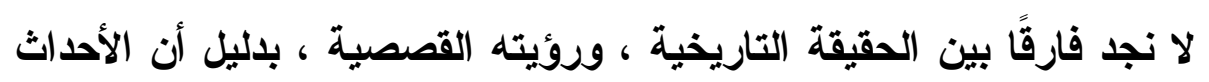

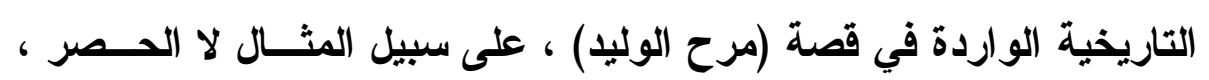

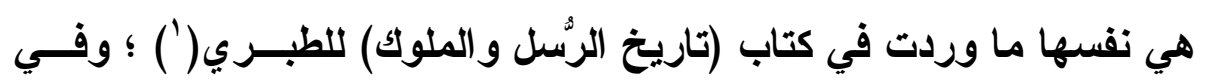

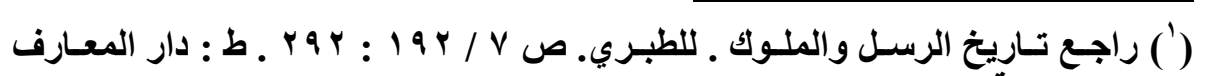

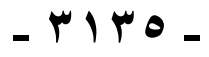


كتاب (الكامل) لابن الأثير(') ؛ وغيرهما من المصادر التاريخيــة التراثيــة

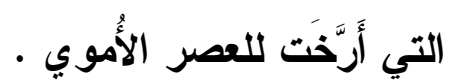

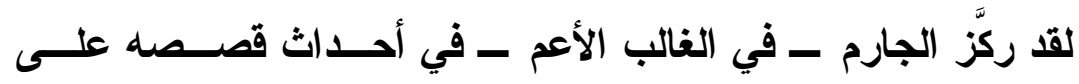

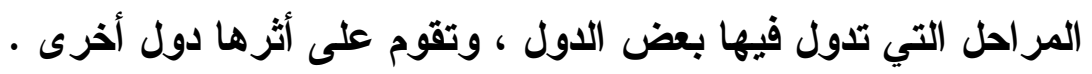

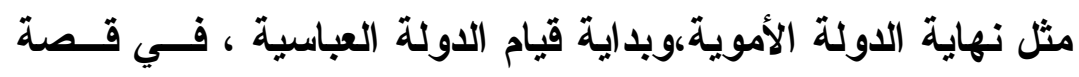

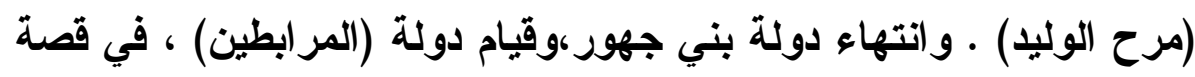

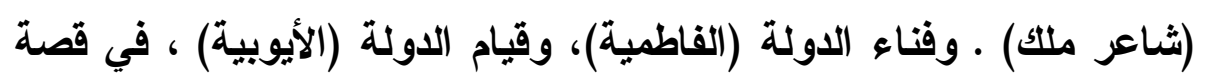

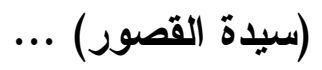

و هكنا كانت الأحداث عند الجارم ـ في الغالب الأعم ـ مستمدة من

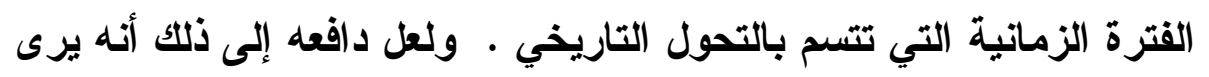

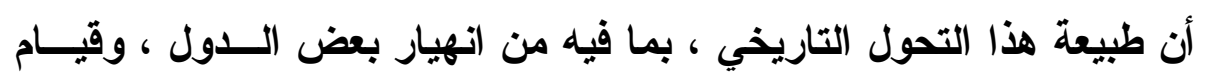

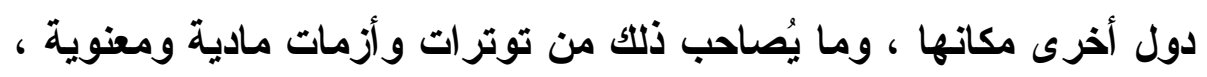

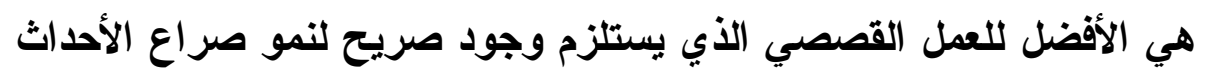
وتطوره ؛ ويجوز أن يكون دافعه إلى اختيار أحداثه من هذه المنعطفـات ،

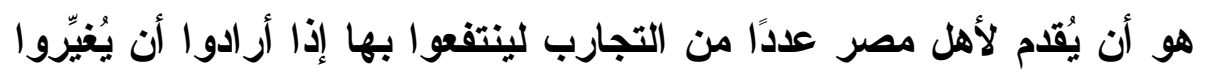

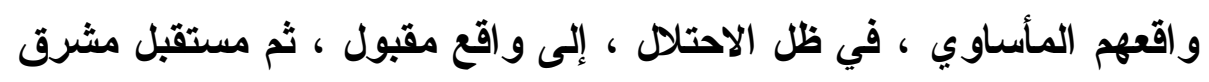

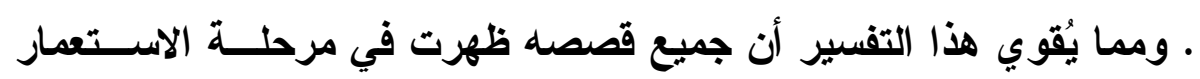

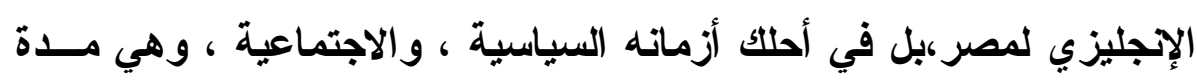

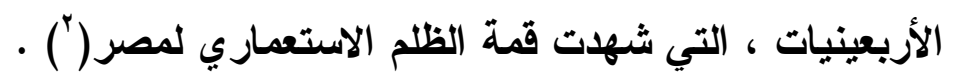

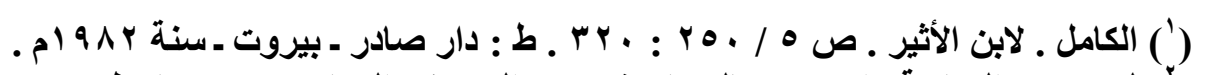

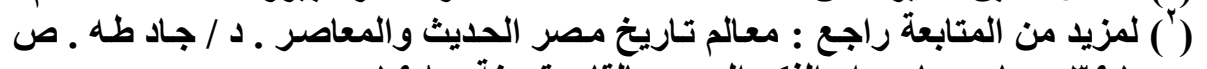

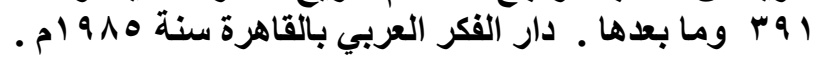


وهكذا كان من أهداف الجارم ـ كما أثرنا ـ انتقاء صفحات من

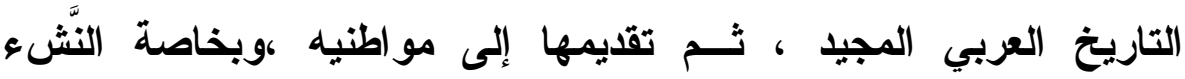
و الثباب ، في صورة قصصية راقية ، للتعليم واستتباط التجارب ل...

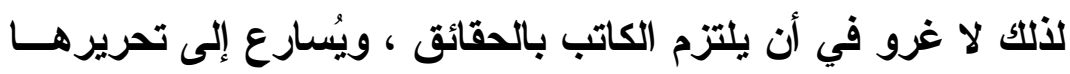
من مصادرها التاريخية الحقيقية .

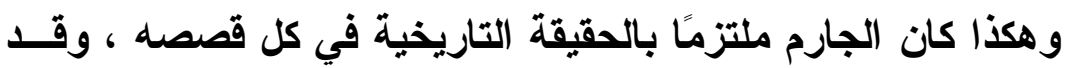

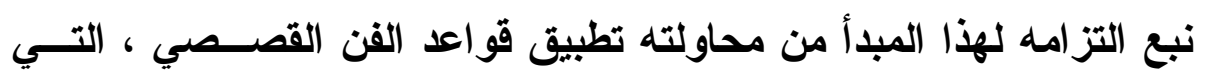

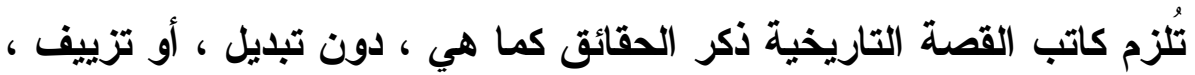

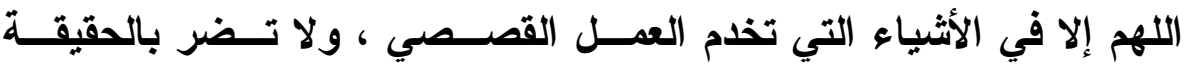

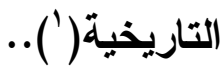

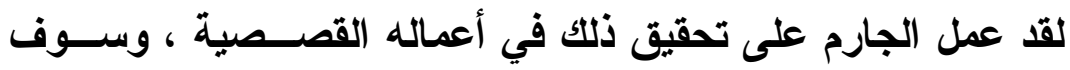

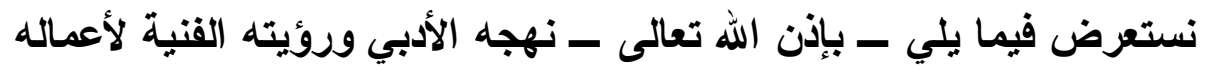
القصصية التاريخية .

\section{**** $* * * * * \quad * * * *$}

\section{نهو صراع الأمداث وتطوره :-}

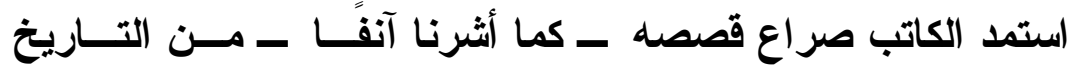

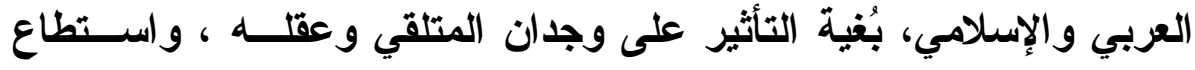
بمقرته الفنية أن يبرز هدفه في قالب متكامل من الخطوط الفنية ، التي من

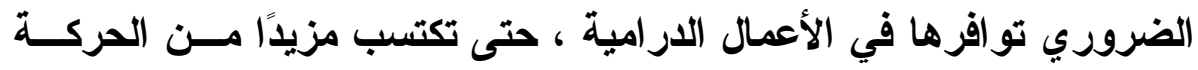
والإثارة ، فكانت على النحو التالي :-

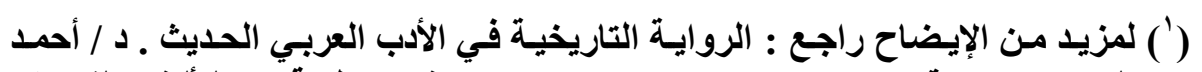

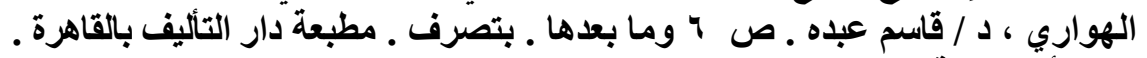




\section{أ ـ هرحلة صراع البداية (الاقدهمة) :-}

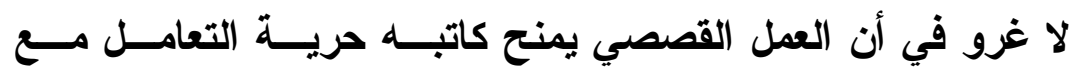

الأحداث، فلا قيا يُفرض عليه اختيار نقطة المقدمة ، أو البداية المرجـوة ،

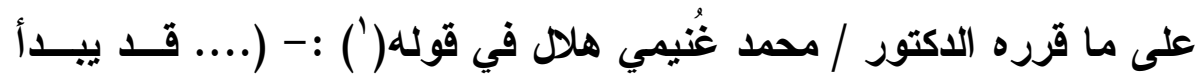

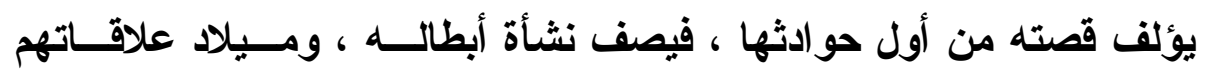
بعضهم ببعض ، ويتبع في ذلك منهجًا زمنيًّا في عرض الأحداث .

وقد يبدأها بالنهاية ،ثم يرجع إلى بيان الأسباب التــي أدت إليهـــا ، وكثف الغامض من أمرها .

وقد يبدأها من فترة خاصة من حياة الشخصية الرئيسية في منظــرِ صامت يعتمد على الوصف اعتمادًا كبيرًا ، ثم يقف ليرجع إلى الوراء سنين كثيرة ،ويشرح بهذا الرجوع المنظر الذي قدمه أولاً ....). و المتأمل في أعمال الجارم القصصية يُرك أنه انتهج طريقتين مـنـ هذه الطرق القنية :1 - الطريقة التي تبدأ من أول حوادثها ، بحيــث تــصور نـشـأة الأبطال وميلادهم وعلاقاتهم بعضهم ببعض .

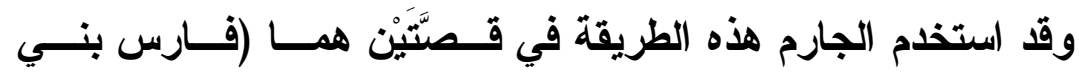

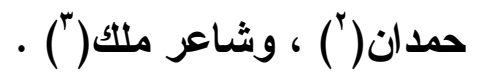

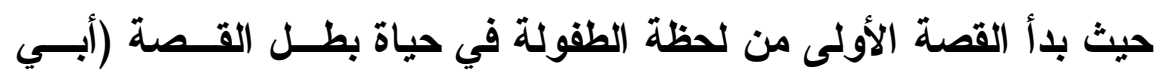

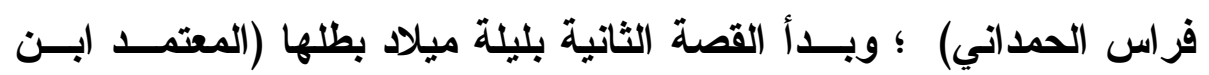

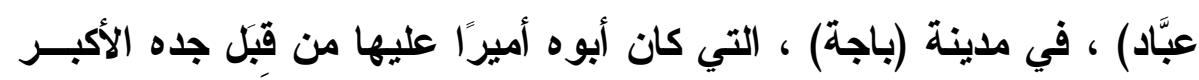
في (أشبيلية) .

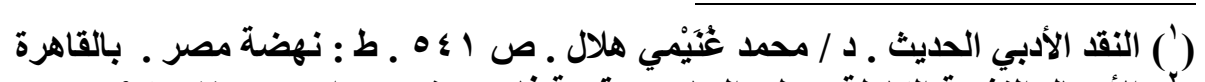

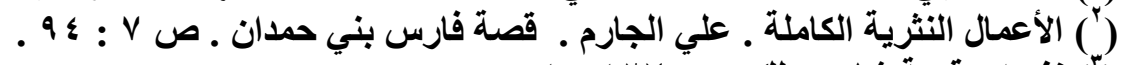

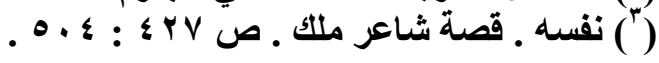
- MIM _ 


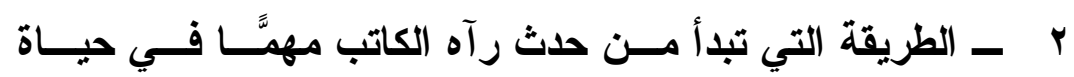

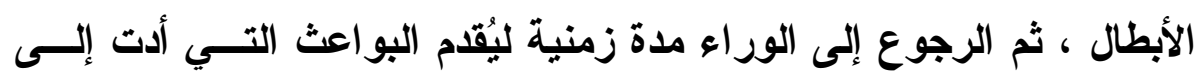

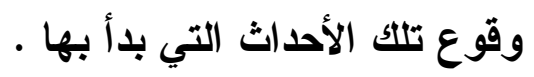

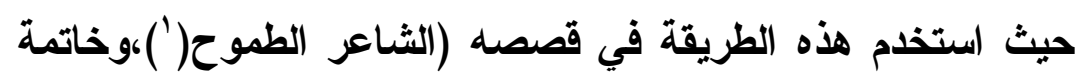

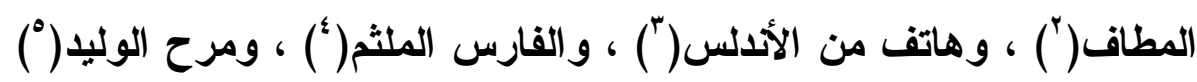

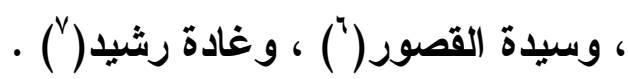

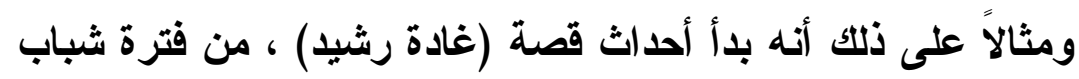

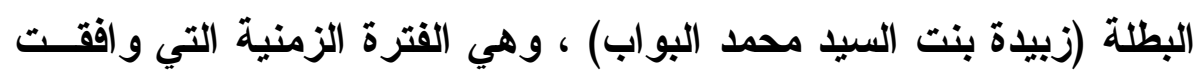

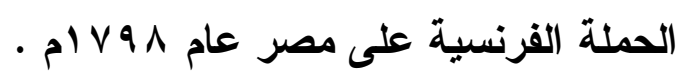

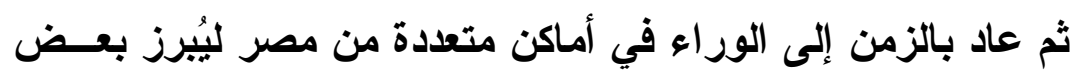
مساوئ المماليك في حكمهم مصر .

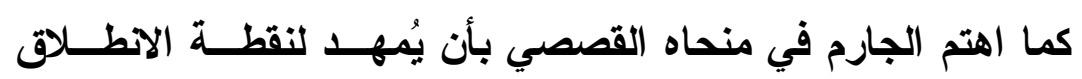

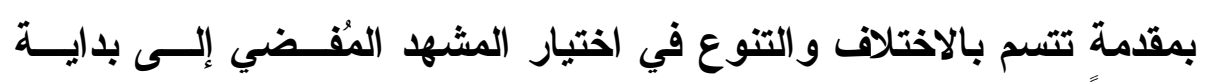

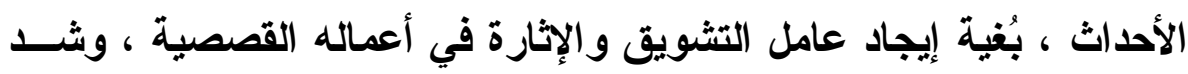
انتباه المتلقي إلى متابعتها ـ الإدال

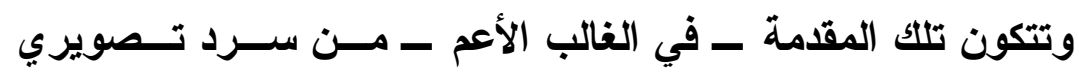

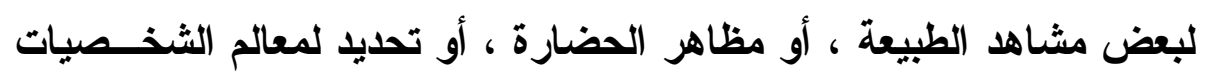

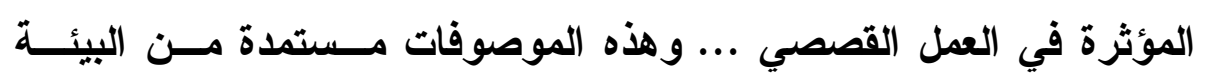

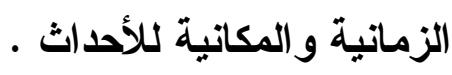

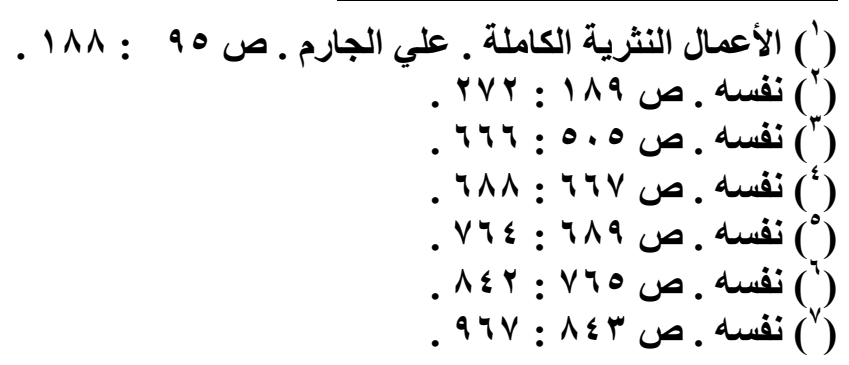


و الجارم في هذا السرد التصويري يحرص على الأســلوب العربــي

المكتظ بالصور البيانية التي تستهوي القارئ .

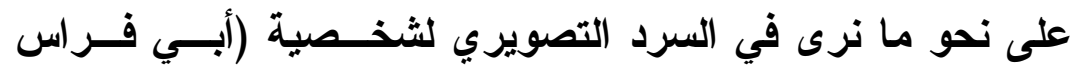

الحمداني) ، في قصة (الشاعر الطموح) ، وهو من أهم شخصياتها :

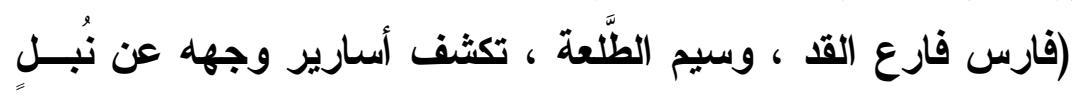

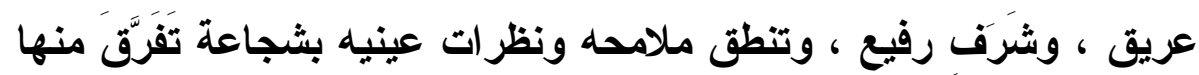

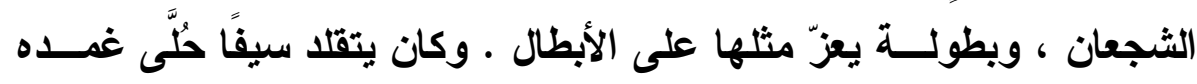

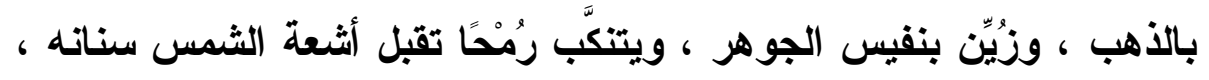

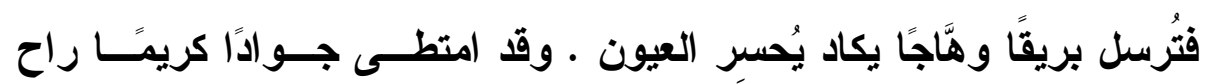

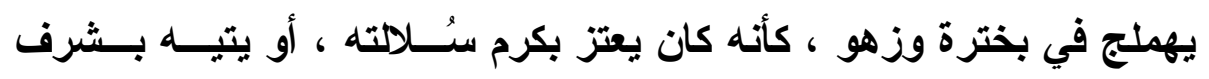

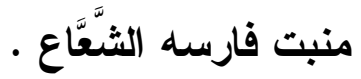

سار الجواد بين الوخد والخبب في طريق مدينة حلب ، فـــي يــوم

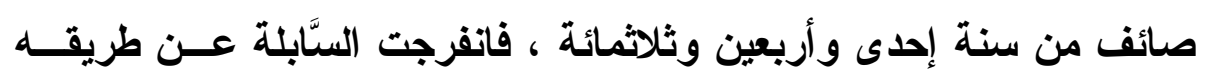

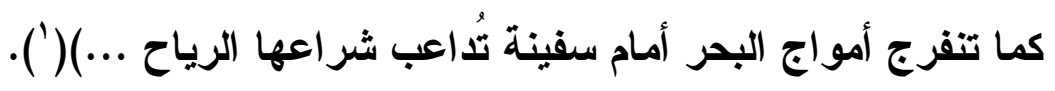

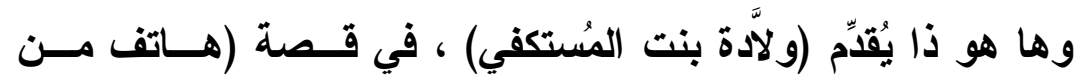

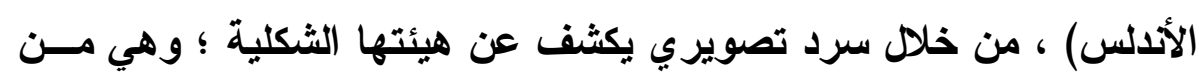

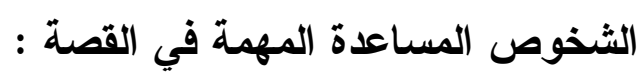

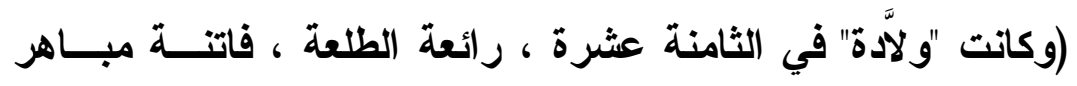

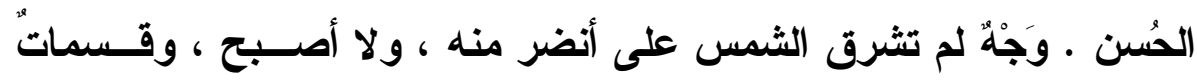

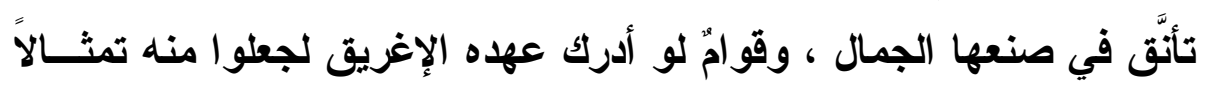

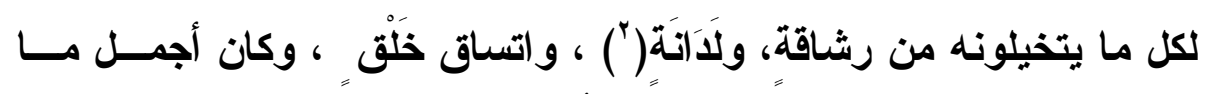

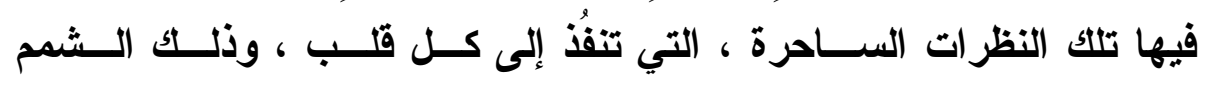

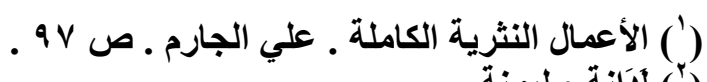

$$
\begin{aligned}
& \text { - rIs. }
\end{aligned}
$$


العَبْثَسمي ، الأي تراه فتحبه وتهابه ، و الذي يوحي إليك أن الجـــال معنسى

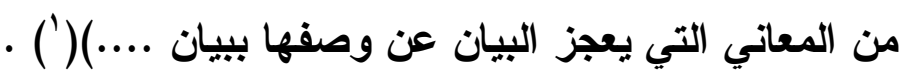

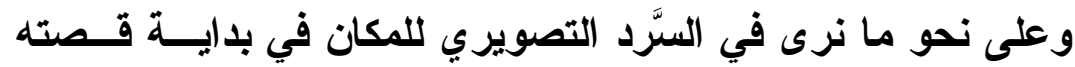

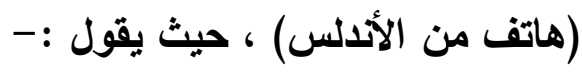

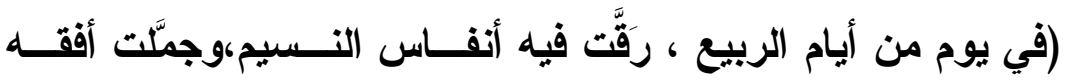

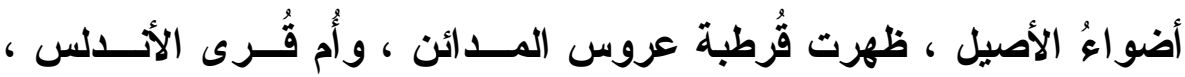

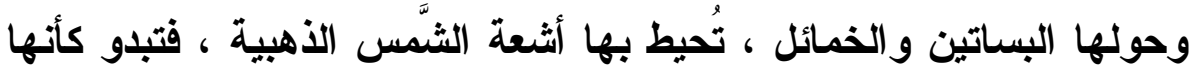
صورة في إطار من ذهب ، وقد انحدر تحت قدميها الــوادي الكبيـر نقيَّـا

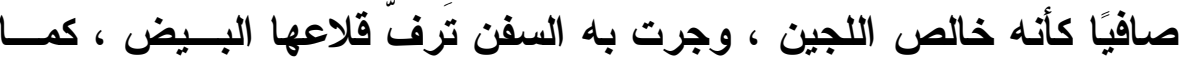

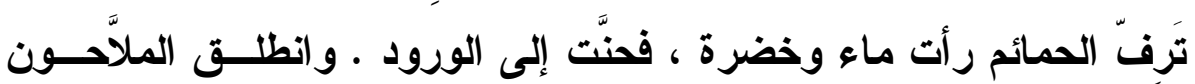

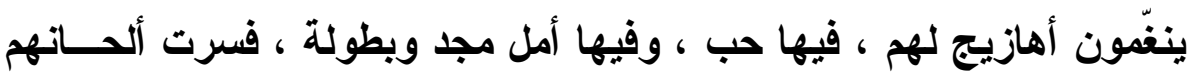

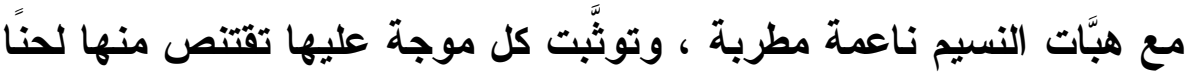

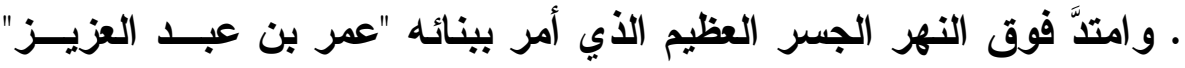

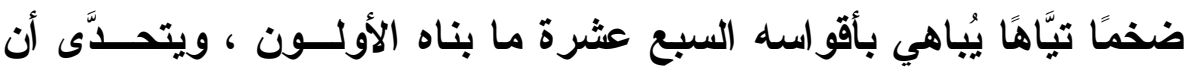

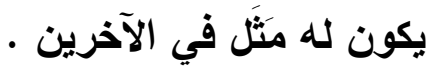

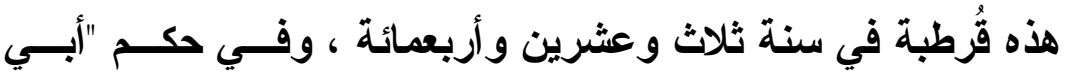

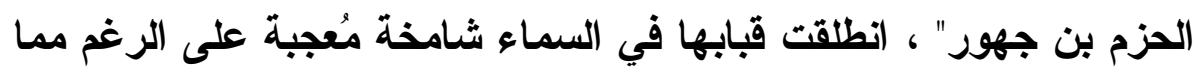

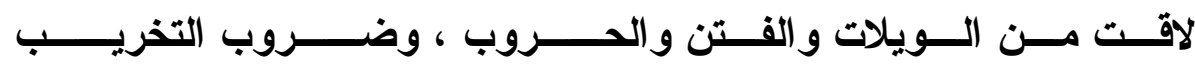

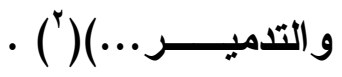

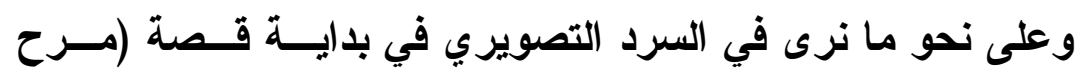

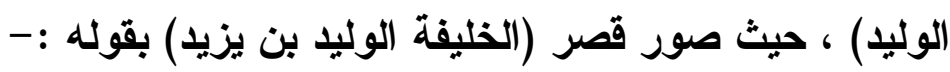

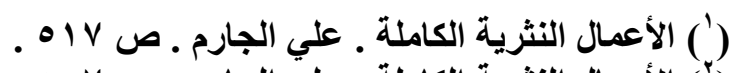

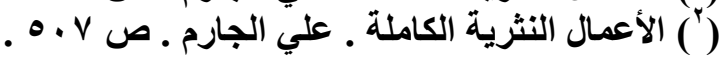
- Ml - 
(قصر راسخ القواعد ، شامخ الذرا ، رسا أصله فوق شرف عـال

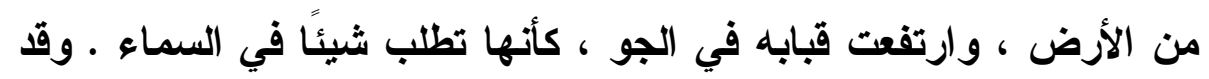

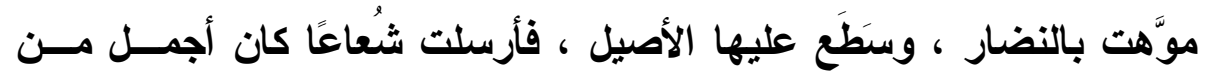

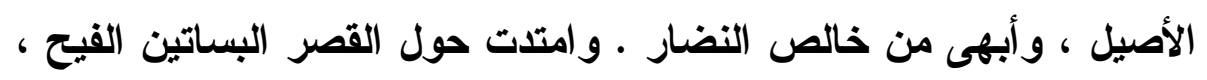

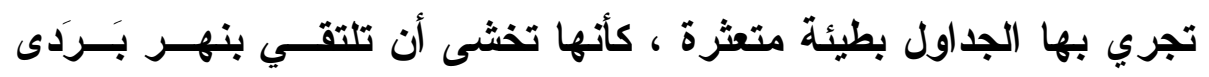

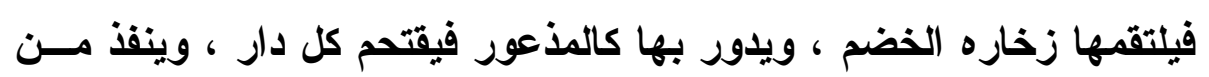

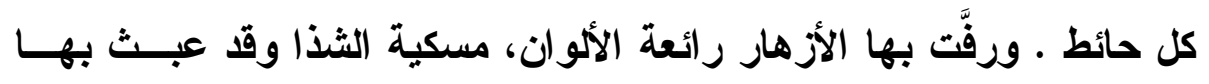

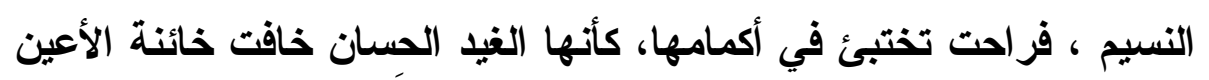

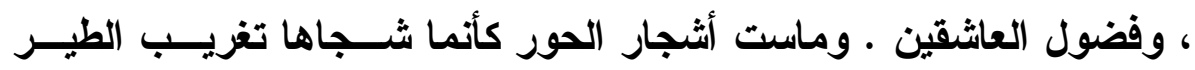

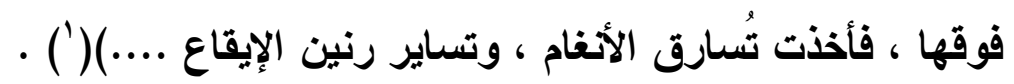

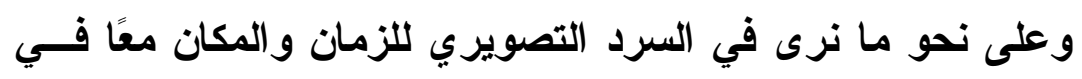

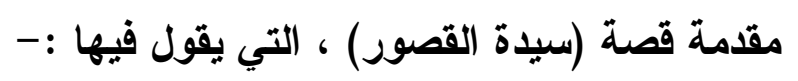

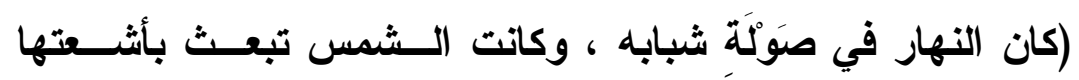

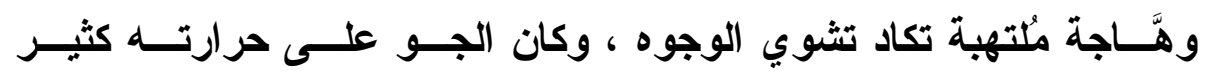

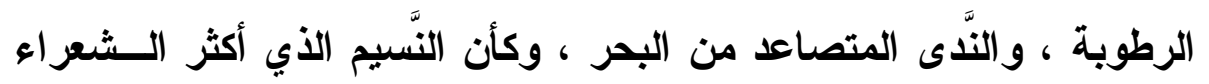

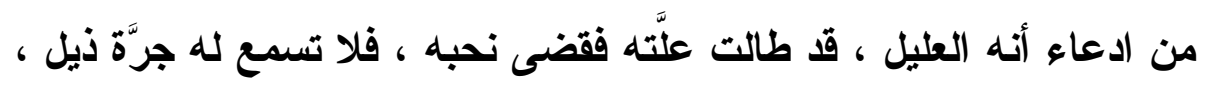
ولا همسة أنين .

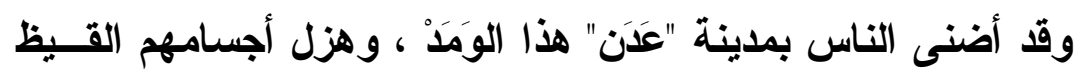

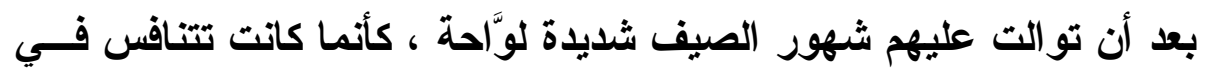

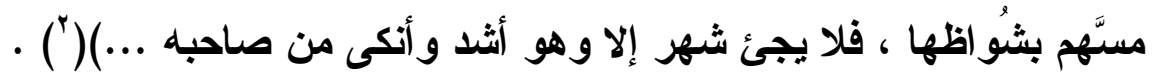


وهكذا كان أسلوب الجارم ـ في الغالب الأعم ـ في اختيار نقطة المقدمة

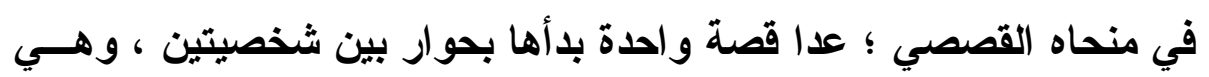

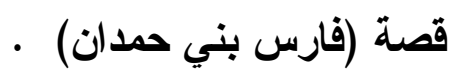
ولعل الكاتب اعتمد على هذا الأسلوب في مقدمات قصصه اتباعًا لقو اعد النقا الأدبي في القديم والحديث . فقد أثشار أبو هلال العسكري إلى ذلك في قوله : -

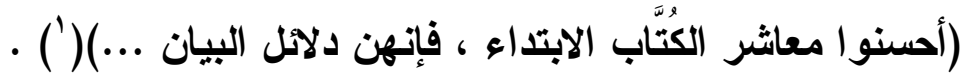

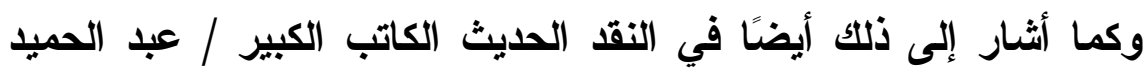

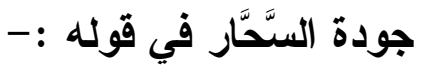

ب) جالـ بالوصف الجيد يُخلق الجو ، ولا ضير أن يستغرق هذا الخلق فـصلاً

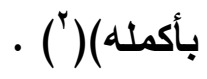

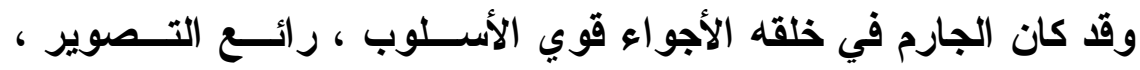
شديد الاحتفاء بأدوات البيان المختلفة .

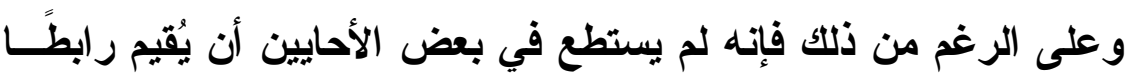

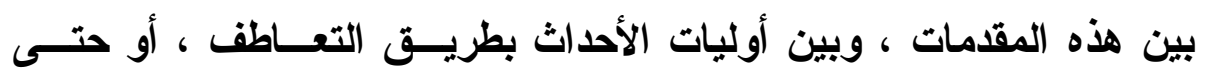

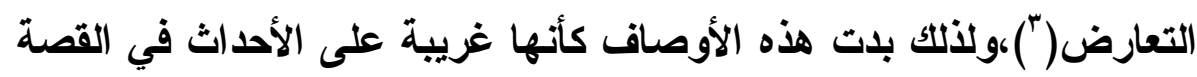

(') الصناعتيـنـ ـ ص إله 01 ؛ ـ تحقيق الأستاذ / محمد علي البيجاوي ، ومحمد أبو الفضل

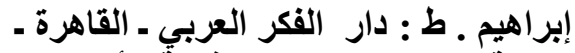

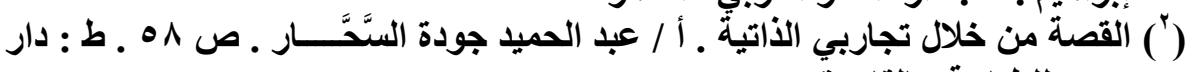
(1) مصر للطباعة بالقاهرة .

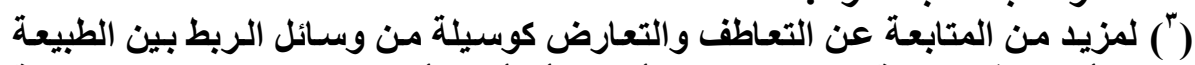

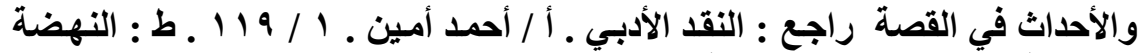

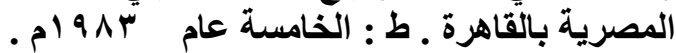

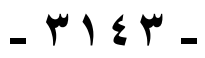


وقد يشعر المتلقي بالملل والتشتت حينما يقوم الكاتب بالفصل بـين

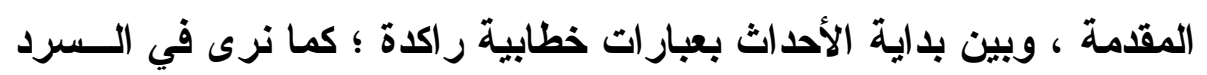

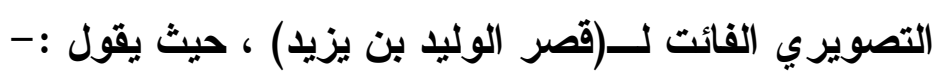

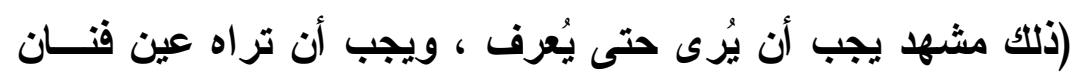

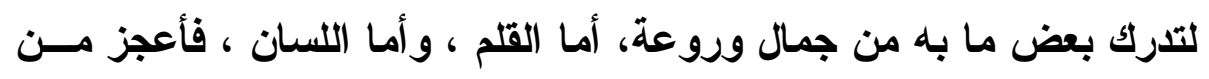

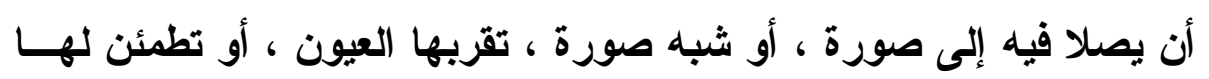

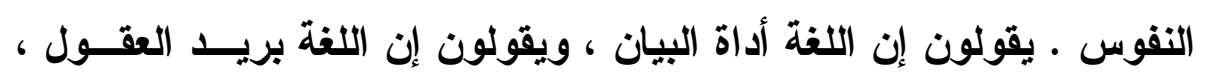

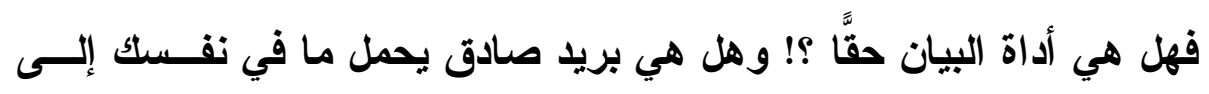

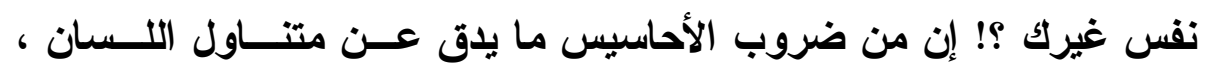
ويستعصي على سنان القلم ....)(') .

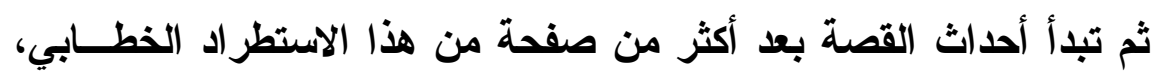

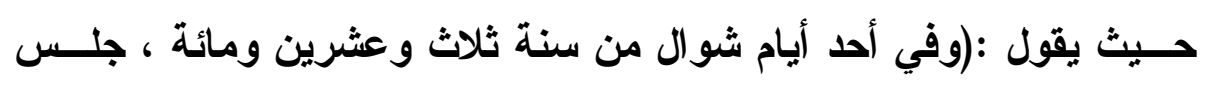

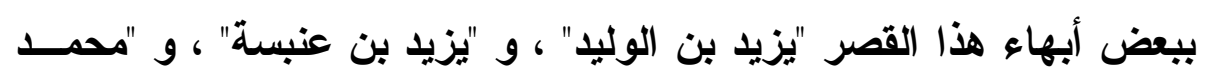

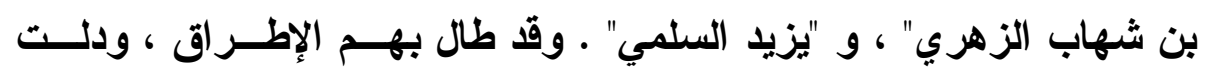

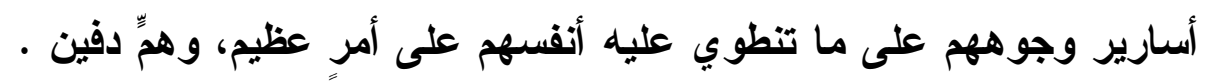

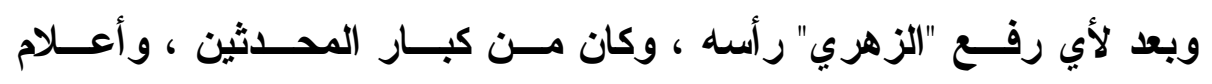

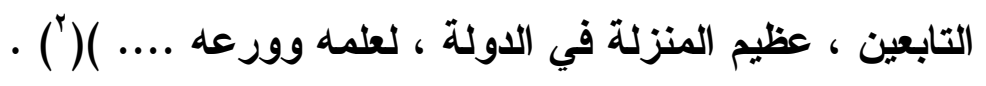

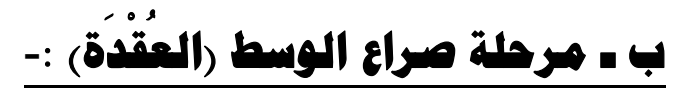

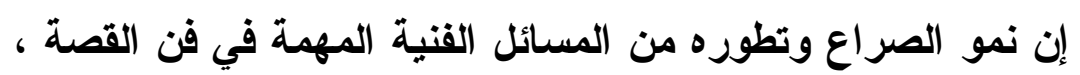

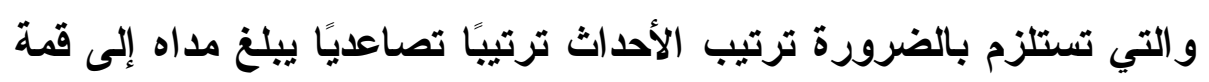

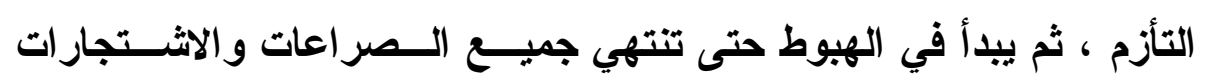

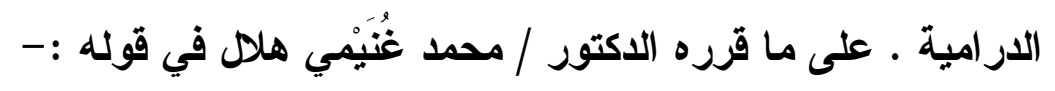

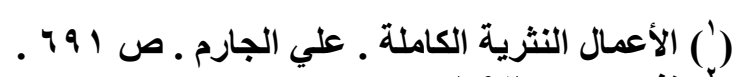

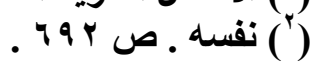
$-\mu 1 \leq \leqslant-$ 
(لا بد من ترتيب الأحاث ترتيبًا تصير به ذات وحدة عـضوية ، فهـي

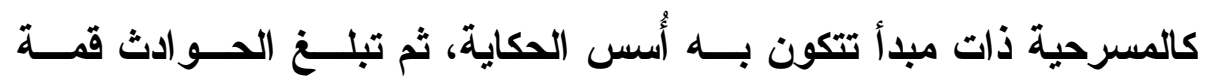
تأزمها ، وتصير إلى نهايتها في الخاتمة ...)(").

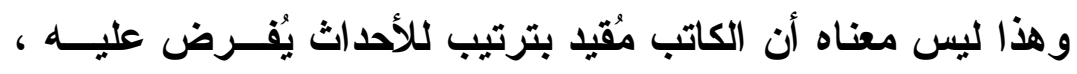

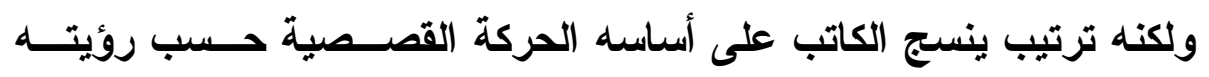

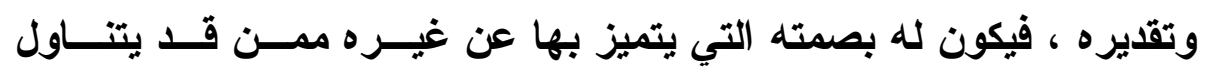
الموضوع ذاته في عمل قصصي .

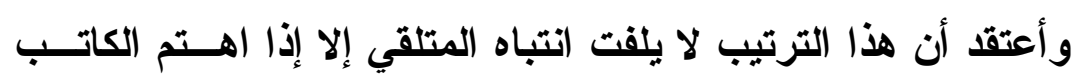

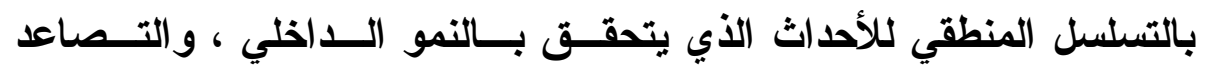

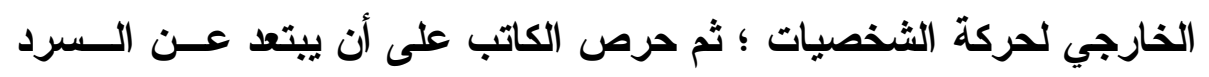

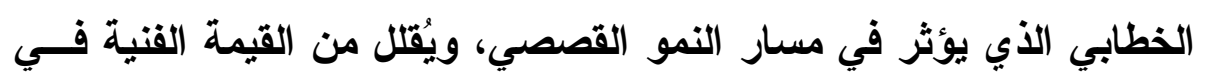

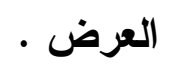

وهذا ما أثثار إليه الاكتور / إبراهيم عوضين في قوله :-

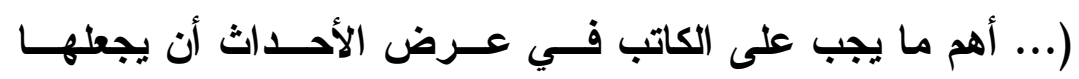

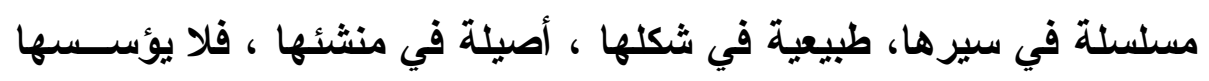

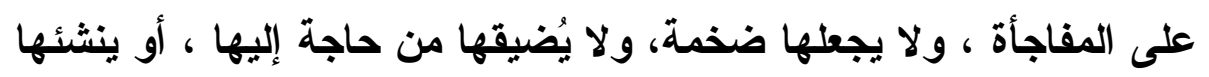

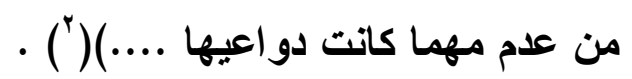

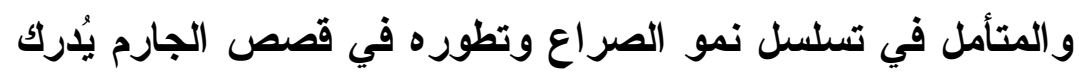
أنه أقامه على محورين ، هما : -

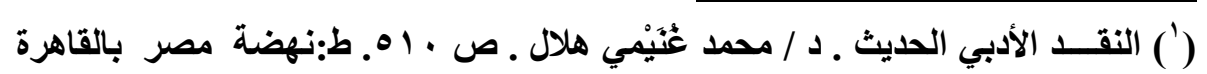

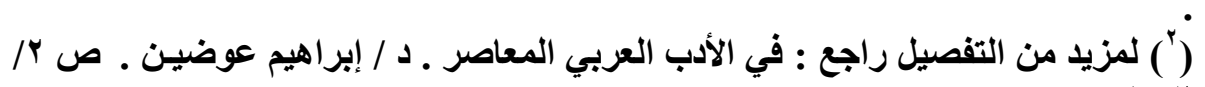


1

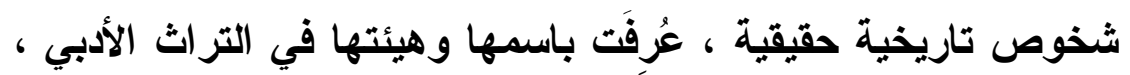

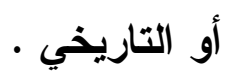

r ـ الاهتمام بالترتيب الزمني للأحداث التاريخية المُراد إلقاء الضَّوء عليها

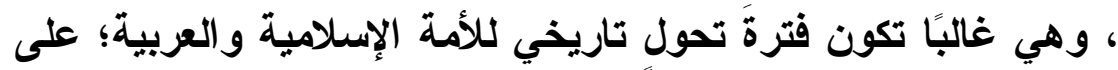
ما قرره الاكتور / محمود حامد شوكت في قوله :-

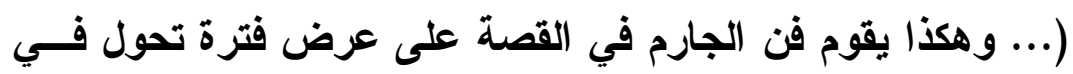

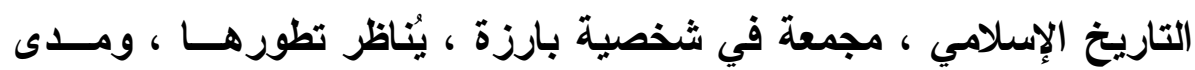

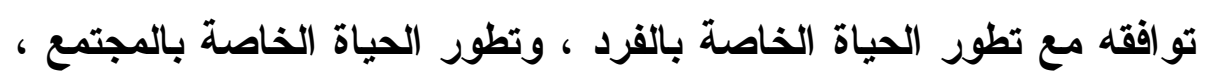
في عرض مُجمل ، قوامه وصف الحوادث الكبرى ، مع اقتباس من الإنشاء

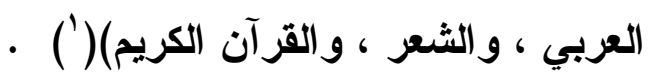

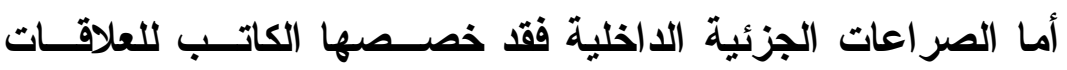

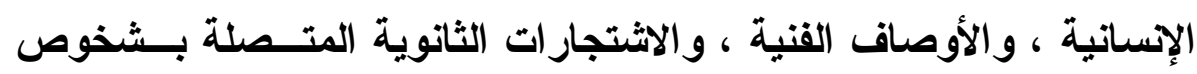
القصة ، و التي تتصارع في بيئة زمنية ومكانية محددة .

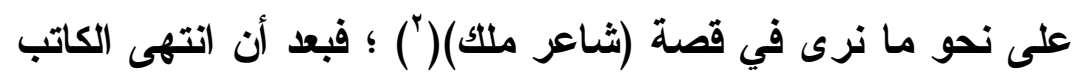

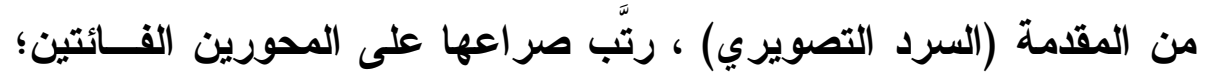

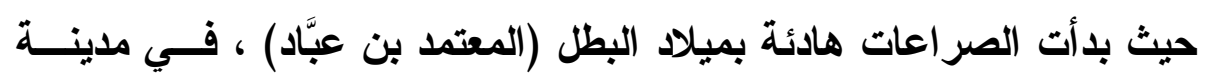
(باجة) ، في الفصول الثلاثة الأولى (ليلة ـ فندق ـ تهنئة)(بّآ) .

$$
\begin{aligned}
& \text { (') الفن القصصي في الأدب العربي الحديث ـ د / محمود حامد شوكت ـ ص } 9 \text { ل الـ دار }
\end{aligned}
$$

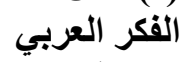

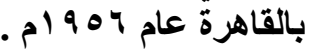

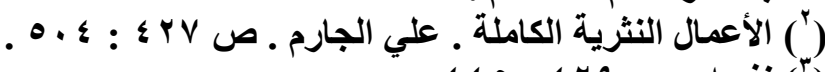

$$
\begin{aligned}
& -M 1 \leq 7-
\end{aligned}
$$


ثم فصنَّل مراحل طقولته الأولى في مدينة (أثشيلية) ، في كنف و الاه

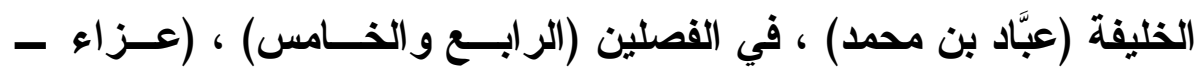

ثم تتبع وقائع حياته في مرحلة الثباب ، و إظهار سماته الثخصية

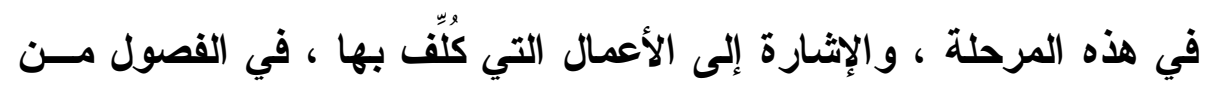

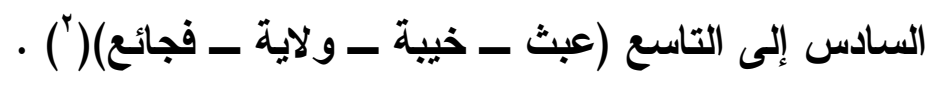

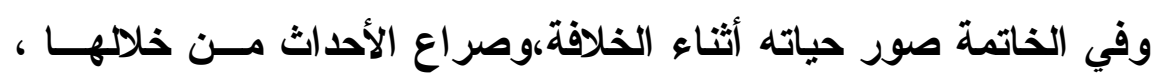
التي انتهت بموته ، وانتهاء دولة بني عباد كلها ، وقيام دولة المـر ابطين

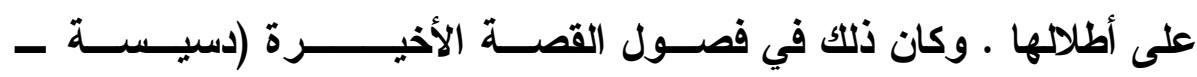

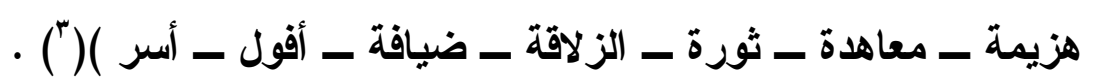

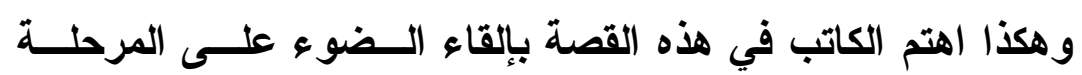

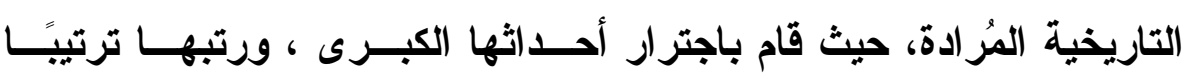

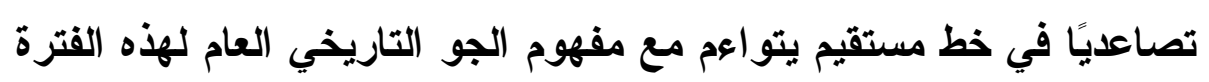

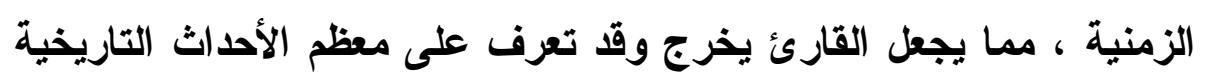

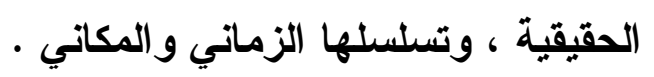

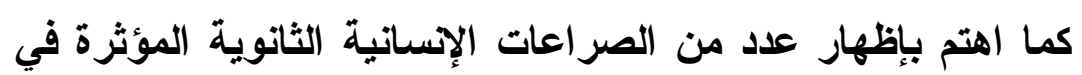

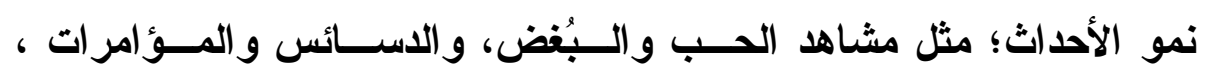
و الندوات الأدبية ، ومجالس الثرب و الغناء . مئل

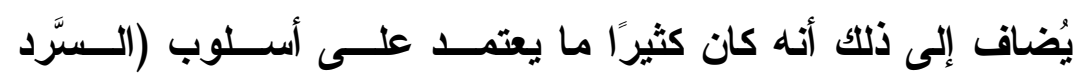

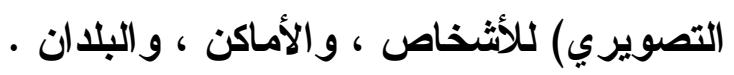


على أن هذا النهج الفني لم يكن في هذه القصة فقط ، بل كان يسير

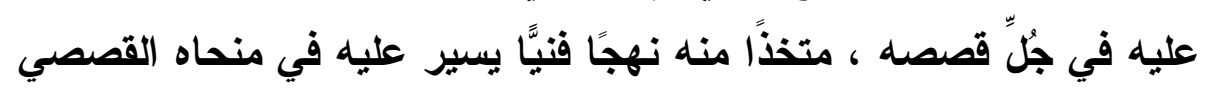

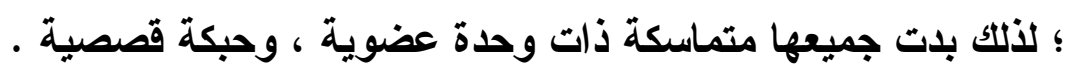

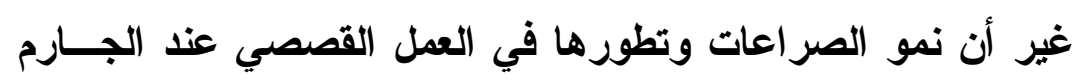

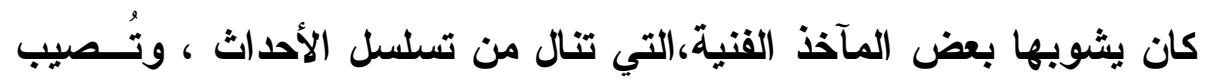

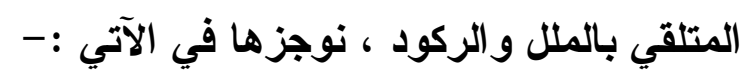

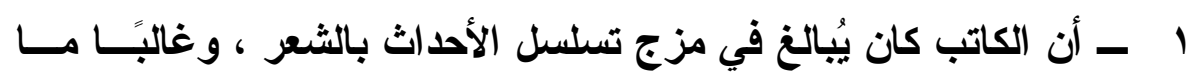
يكون ذلك على لسان الثخصية المحورية في القصة (البطل).

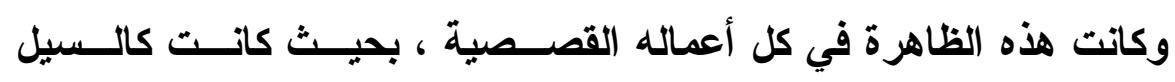
الجارف .

فلا تكاد تخلو صفحة من صفحات قصصه مــن بيـــ ، أو بيتـين ، أو

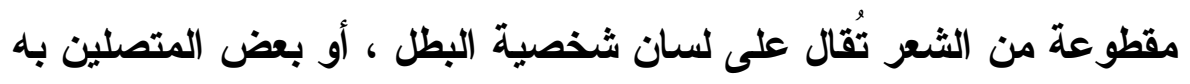

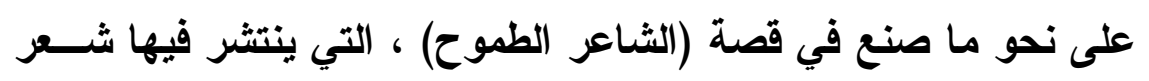

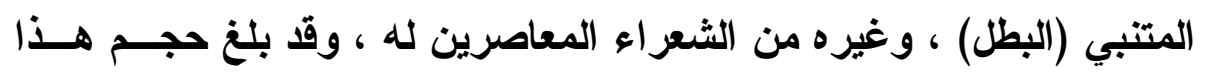

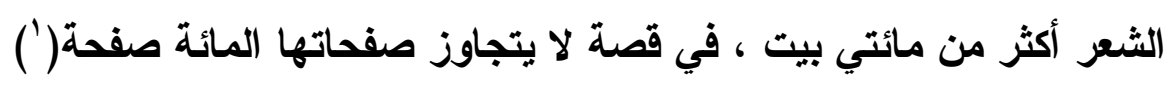

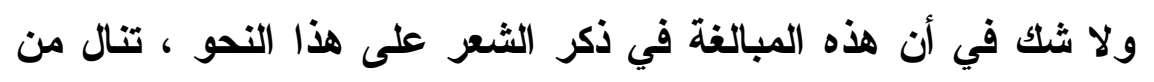

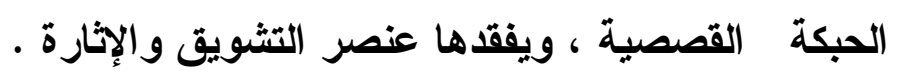

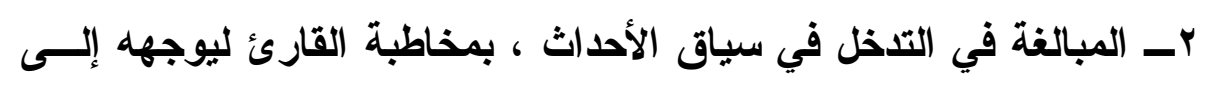

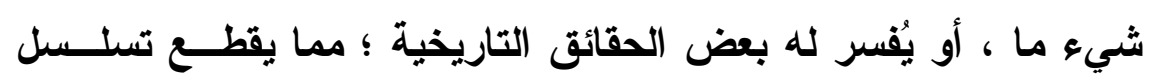

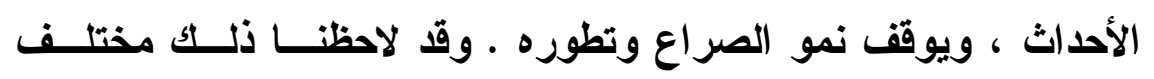
قصصه .

على نحو ما نرى في قصة (غادة رشيد) ، التي ينتشر فــي سـياق

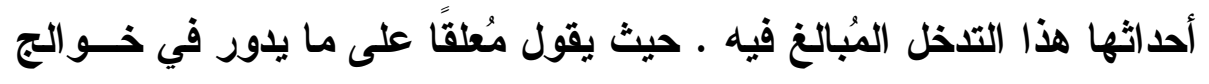

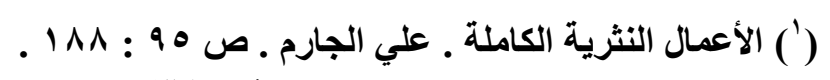
- 
نفس (أم زبيدة) ، حينما وجدت (محمودًا) غير مكترث بحديث الحسب مــع فئح

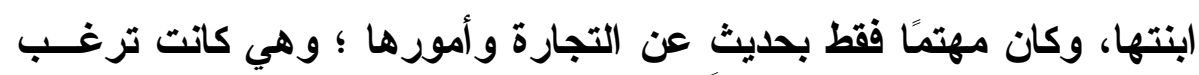
في أن يكون الحديث عن الأمر الأول :-

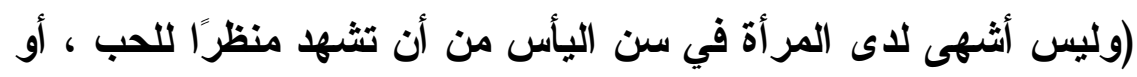

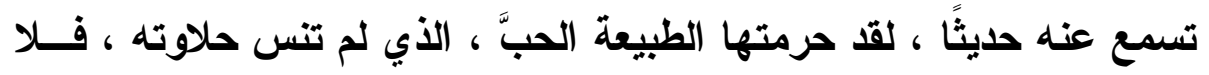

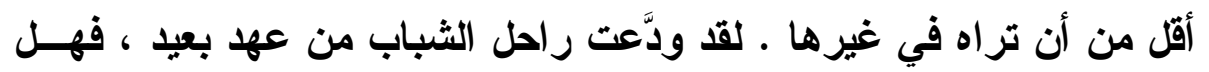

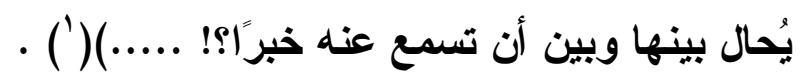

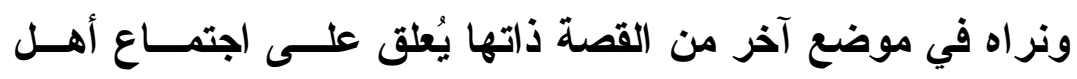

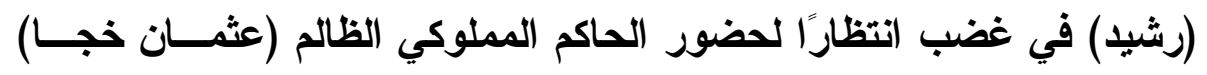

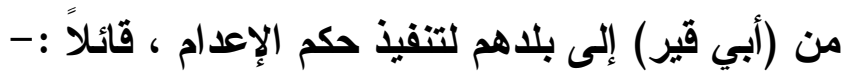

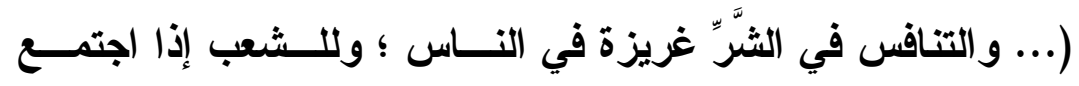

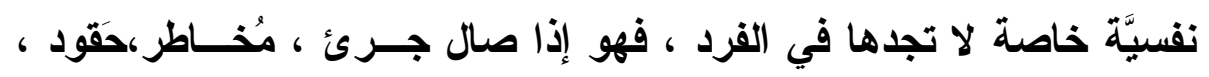

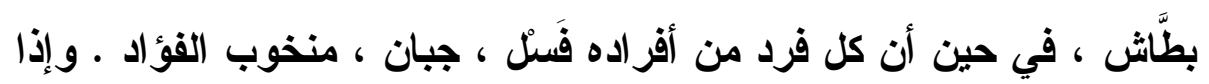

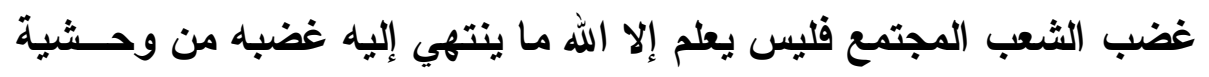

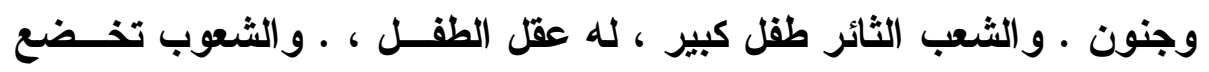

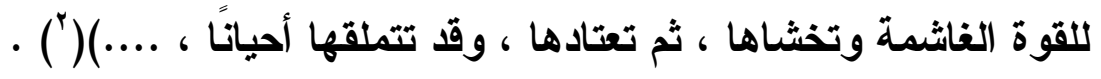

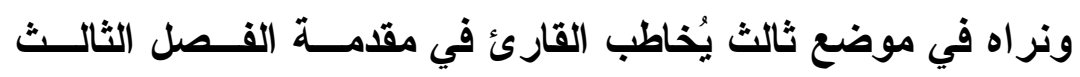

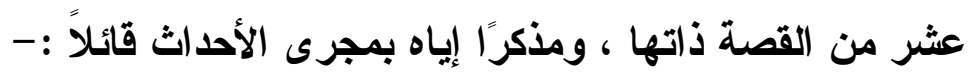

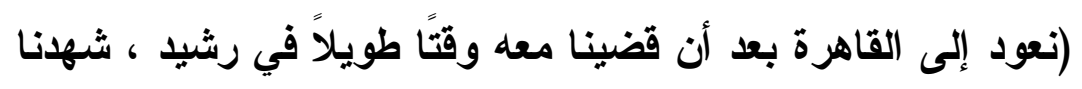

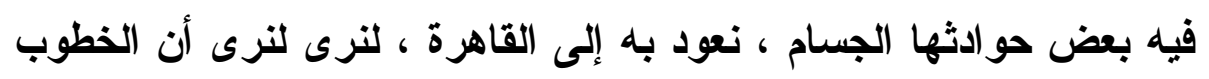




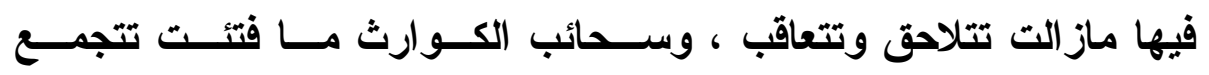

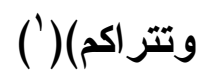

و هكذا كان الجارم يتلخل في سياق الأحاث في جُلِّ قصصه ، بحيث

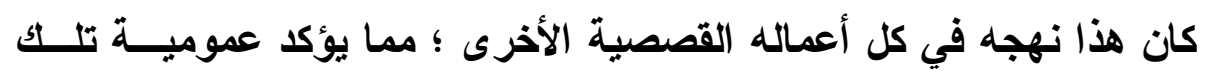
الظاهرة ، وشموليتها في المنحى القصصي لاى الكاتب .

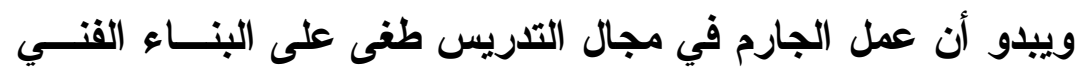

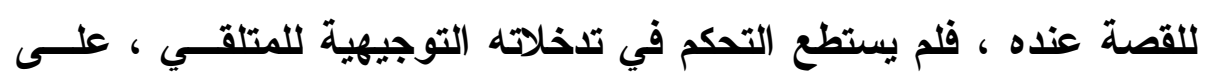

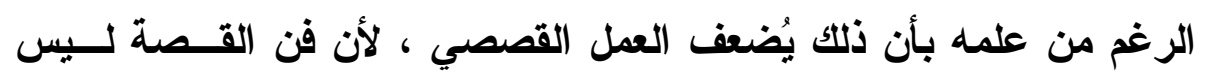

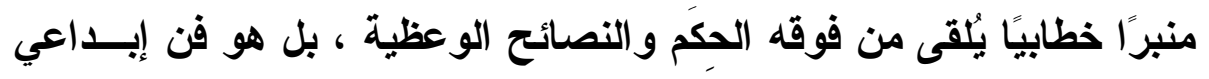

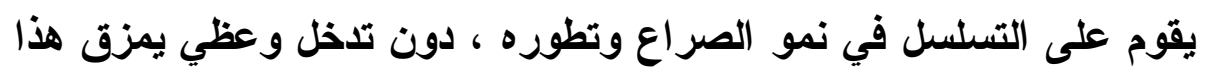
التسلسل ، ويُشتت ذهن القارئ .

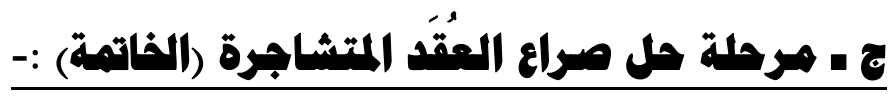

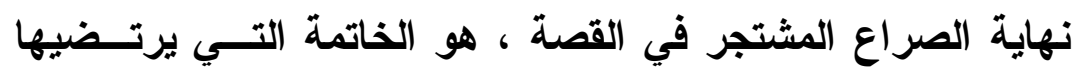

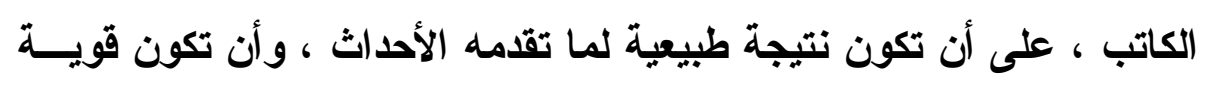

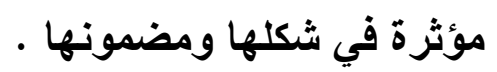

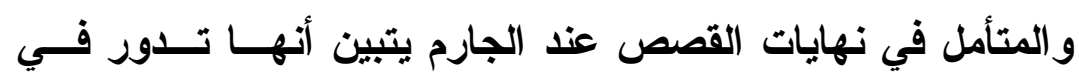
محورين ، هما : 1 الأبطال، بعد موتهر ، في صورة مأساوية حزينة .

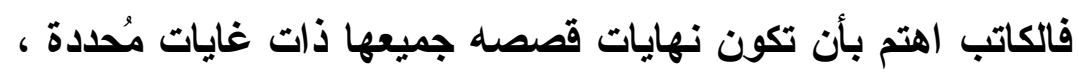

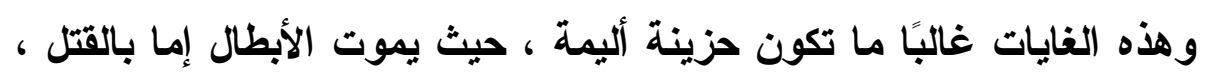

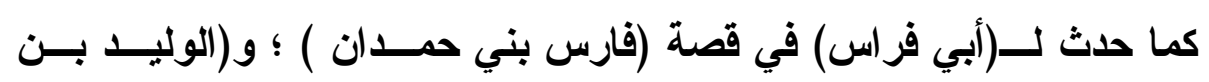
يزيد) في قصة (مرح الوليد) .

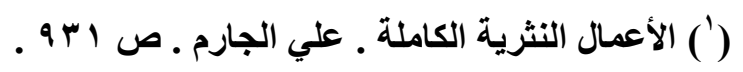


و إما يكون الموت شنقًا، كما حدث لــ(عمارة اليمني) ، في قصة (سـيدة

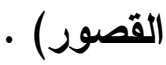

و إمـا يكون الموت حزنًا وكمدًا ، كما حدث لــ(للمعتمد بن عبَّـاد)، فــي

قصة (شاعر ملك) ، و (زبيدة بنت البواب) في قصة (غادة رشيد) .

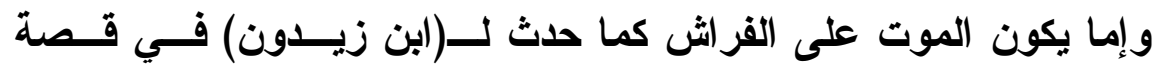

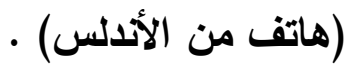

على أن يَعْقب موت الأبطال بالطريقة السالفة الذكر ، تغير الأحوال فـــي

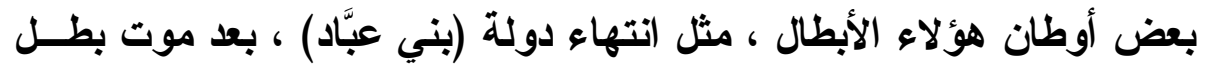
القصة ، وقيام دولة (المُرابطين) على أطلالها .

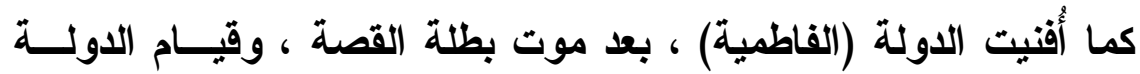

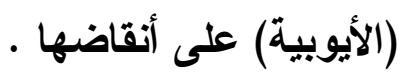

r _ الاعتماد على النهايات السريعة المؤثرة ، التي تتسم بــالقوة

الفاعلة في الشكل والمضمون ؛ التي فضلها الكاتب حقيقية مسأخوذة مسن سيرة (الأبطال) في كتب التراث ، متضمنة كثيرًا من أبيات الثعر ، وآيــات

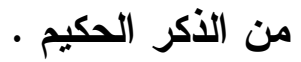
على نحو ما نرى في نهاية قصة (شـاعر ملــك)(') ، التـــــي يقــــول فيهـا :-

سارت السفن بابن عبَّاد و أسرته في غم ونواح : ملك زال كأنه ضــحوة من نهار، وعز طار كأنه حلم نائم ، وسطوة وسلطان حـلَّ مكــانهم الــذل فئل

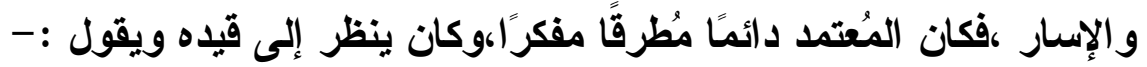

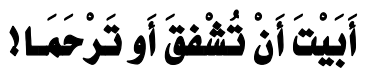

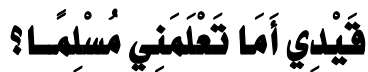

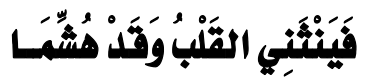

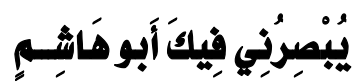

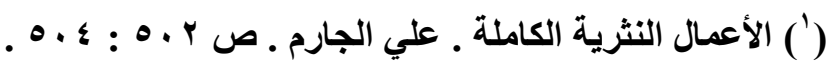


ولما بلغت السفن "طنجة" ، رأى "المُعتمد" جماعة بالبادية يستسقون

لقلة المطر، وشدة الجفاف ، فقال :-

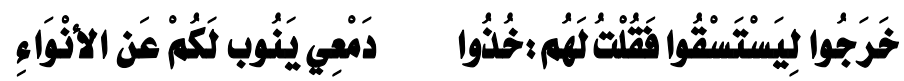

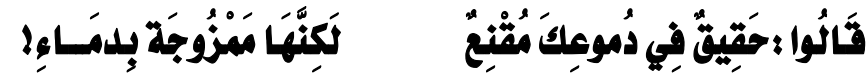

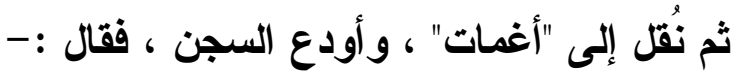

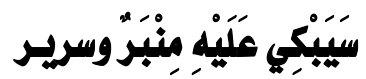

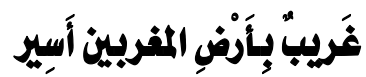

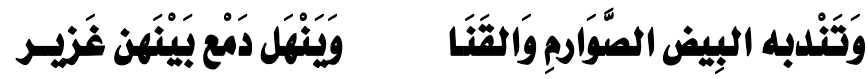

وكاتت بناته يعشن في السجن من غزل أيديهن ، في فقــر وكفــاف

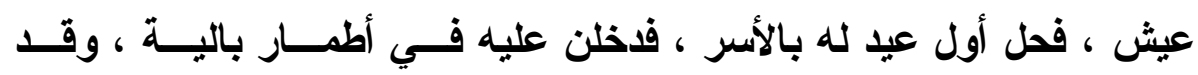

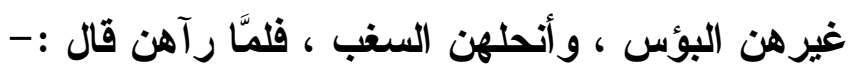

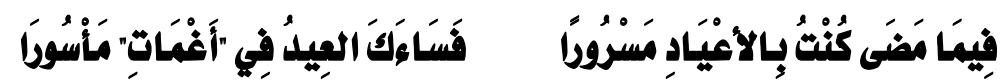

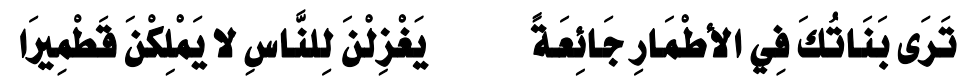

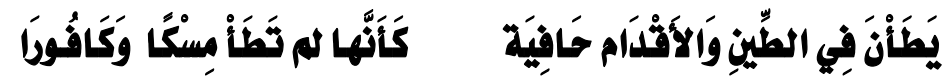

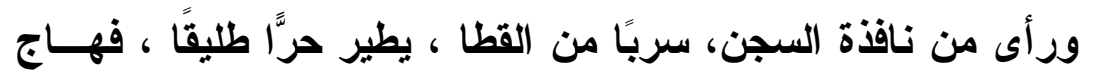

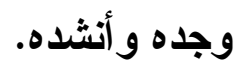

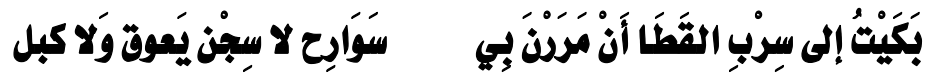

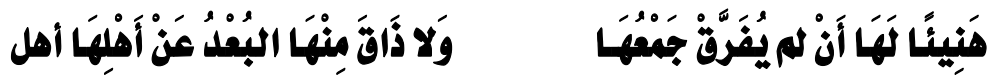

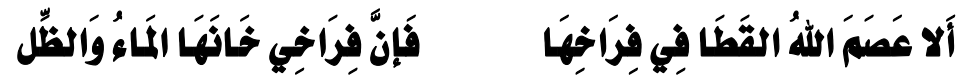

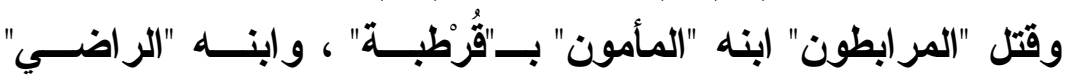

بـ-رندة" ، فز اد جزعه ، و اشتتد حزنه ، فقال :-

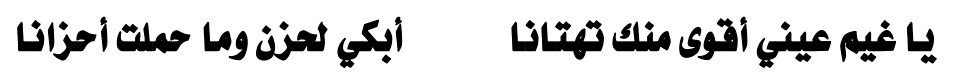

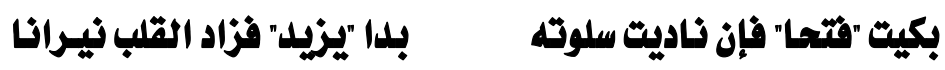

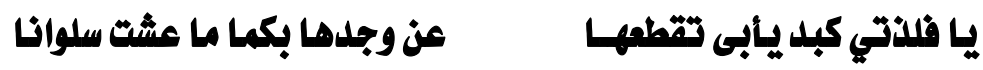


ولم يزل في أنين وحنين ، يرسل الزفرات ، ويطوي صدره اليأس ،

حتى أدركته منيته ، سنة ثمان وثمانين وأربعمائة .

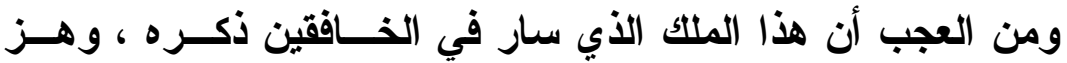

أعطاف الزمان شعره ، وكان اسمه على كل لسان ، و الثناء عليـهـ يجلجـل

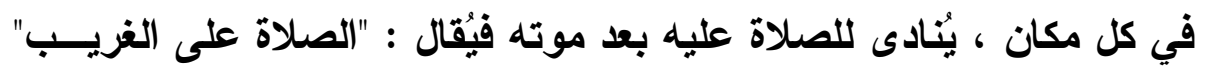

إن من الغريب أن يكون ابن عبَّادًا غريبًا !! .

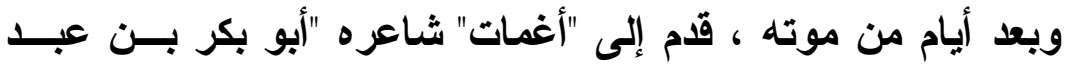

الصمد" ، وكان اليوم يوم عيد ، فوقف على قبره خاثعًا باكيًا .

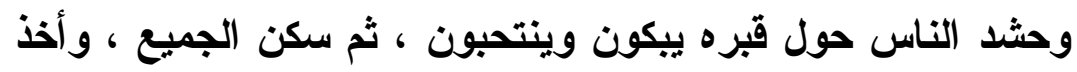

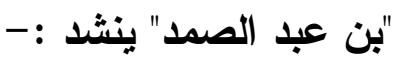

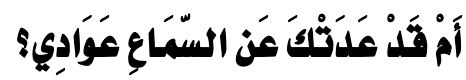

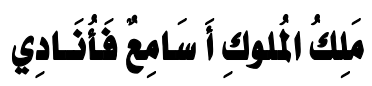

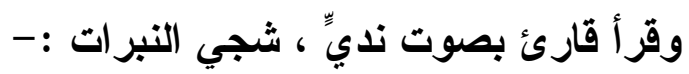

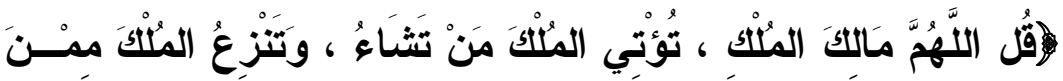

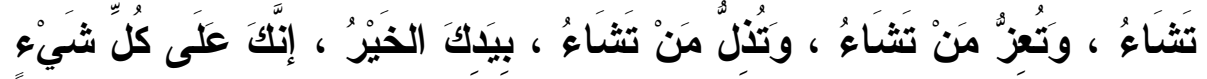

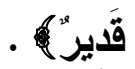

وعلى نحو ما نرى في نهاية قصة (فارس بني حمدان) ، التي يقول

ومرت سنة مات فيها (سيف الدولة)،فترك موته في كل نفس لوعة

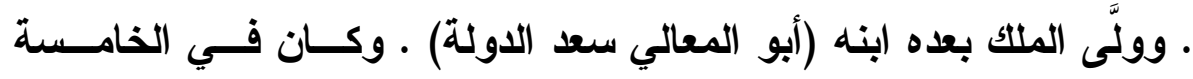

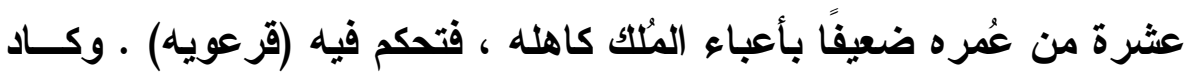

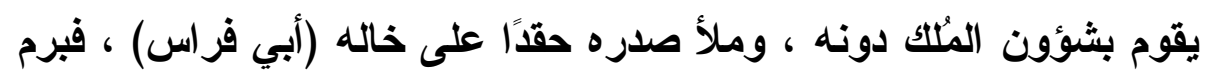

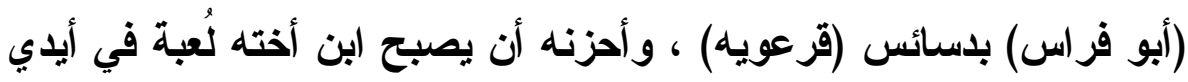

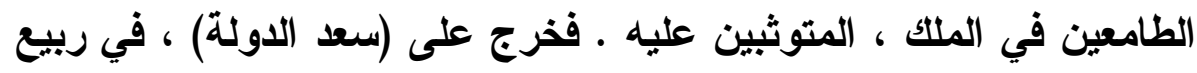


الآخر سنة سبع وخمسين وثُلاثمائة ، وضم إليه بعض الجنود ، وسار بهــ

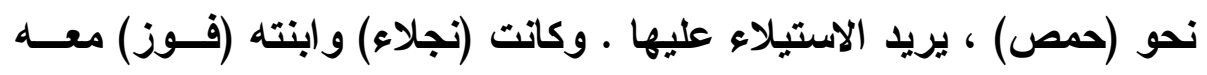

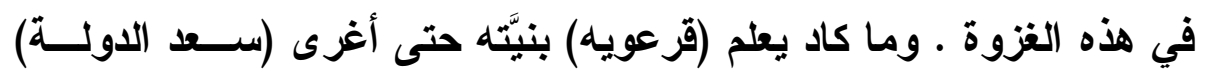

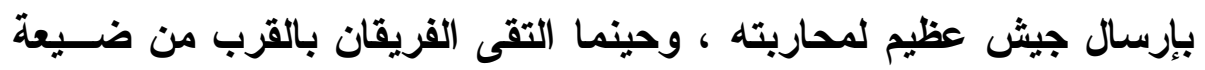

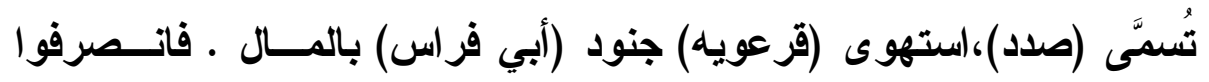
عنه، ودهمه بجيش كثير العُدَّة و العُدَد .

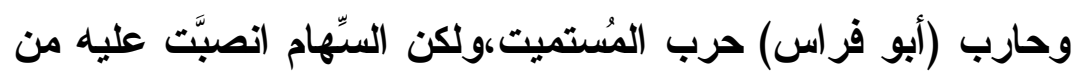

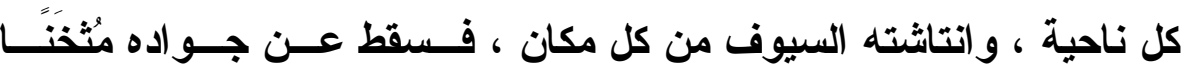

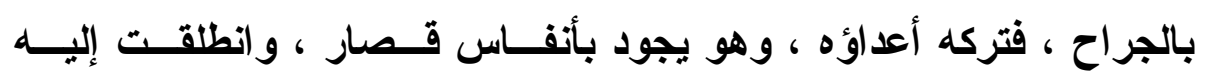

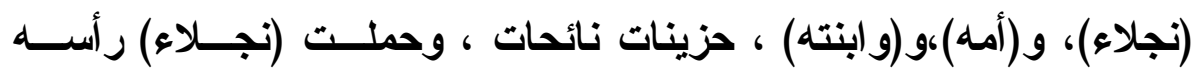

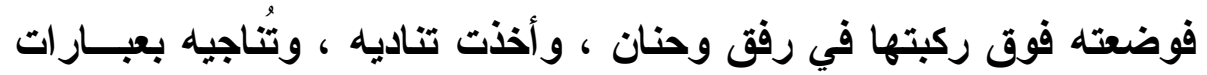

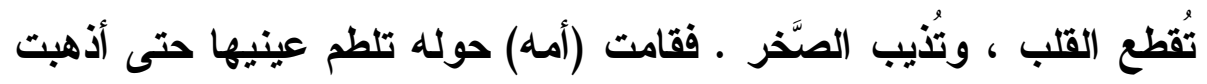

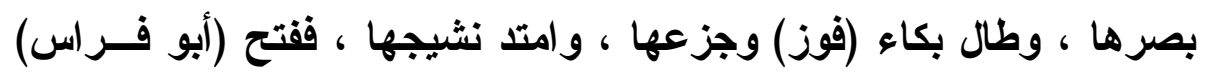

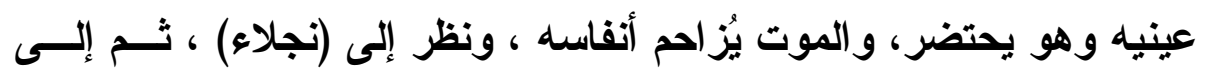

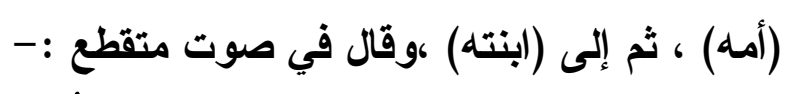

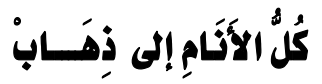

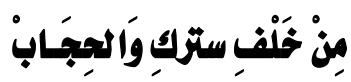

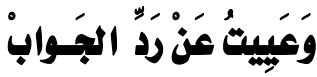

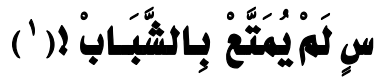
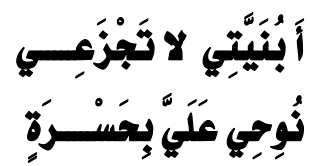

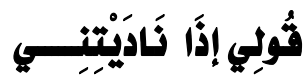

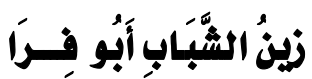

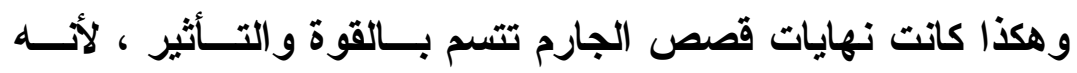

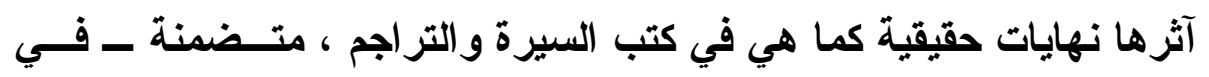

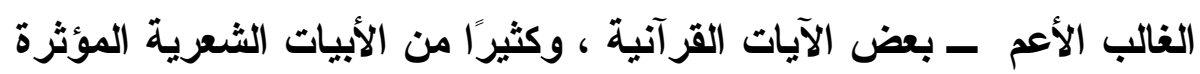
في وجدان المتلقي وعقله .

(') الأعمال النثرية الكاملة . علي الجارم ـ ص ب ץو . 


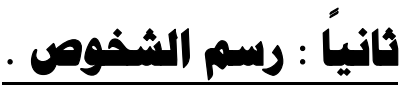

تنبع الشخوص المستخدمة في العمل القصصي من أمرين، هما :

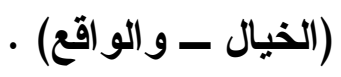

وهي تنقسم باعتبار أهميتها فــي الحبكــة الفتبــة إلــى شخــصية

$$
\text { (محورية) ، وأخرى (مساعدة) . }
$$

فالشخوص (المحورية) ، هي التي تتعلق بها الأحــــاث ، وتتطــور

بتطورهـــا ، وتكتمل ملامحها بنهاياتها،وهي في حالة اثــتجار دائسـم مـــع

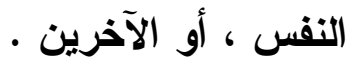

وهذه الشخوص تكون دائمًا حيَّة (مقتعة في العمـل القصــصي إذا

اتبع الكاتب عدة أمور من أهمها : أن يضع الكاتب لها اسمًا ، وأن يوضـــح

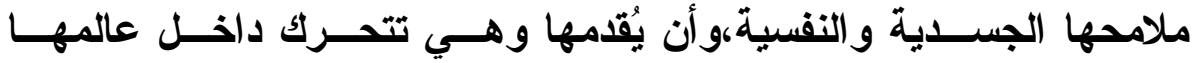
القصصي ، وأن يجعلها وفيَّة لطبيعة النموذج الأي تعكسـ صــورته فـي

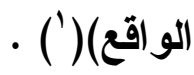

وعلى الكاتب أن يعمل جاهدًا على تلاحم جميع شـــوص قـــه ، بحيث يظهر واضـــاً ما بينها من تناسق وتلاؤم،من خلال التعــاون التــام بينها ، دون تنافر أو نفور ؛ فتظهر كل شخصية مؤثرة بشكل مباشــر فــي

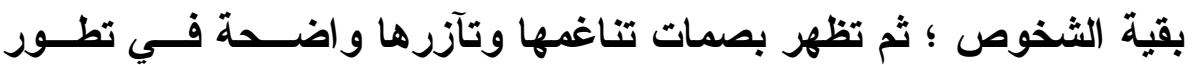
الحدث ونموه ـ على ما قرره الدكتور/طه وادي في قوله :-

(... مثل فريق يعزف ـ سيمفونية ـ موسيقية ، على كل فرد منهم

أن يعزف بآلة خاصة به وحده ، وهم جميعًا رغم التمايز والاخــتلاف ، وأن بعضهم يجلس في المقدمة ، وبعضهم يقف في الصفوف الخلقية ..... رغم

(') دراسات في نقد الرواية ـ د / طه وادي ـ ص ه ب وما بعدها ـ دار المعارف بالقاهرة .

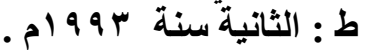




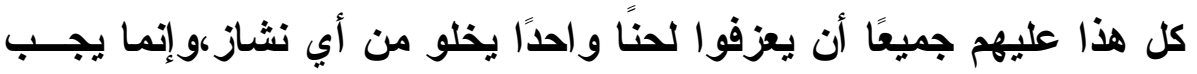

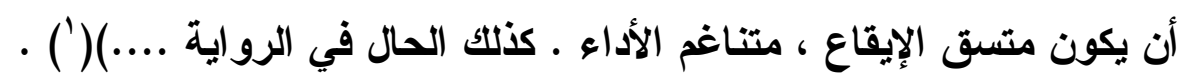

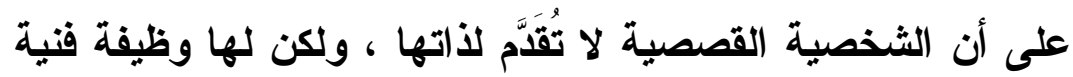

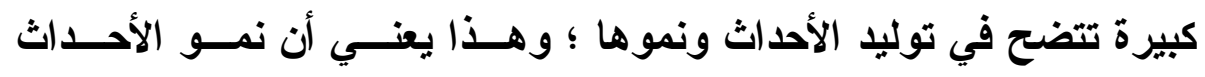

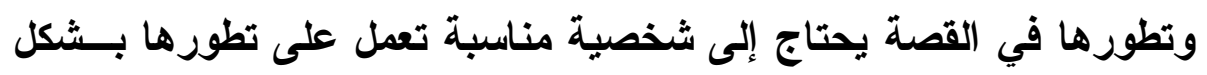
متصاعد ومتسلسل . لذلك كان على الكاتب الاهتمام برسم الثخوص القصصية الملامــة

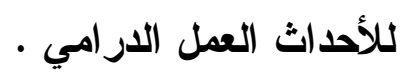
ويُعد عنصر رسم الثخصية الإنسانية من أبرز العناصر التي يعتمد

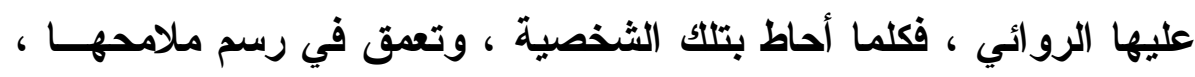

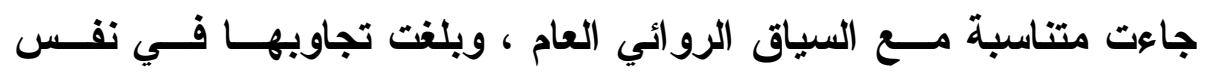
متلقيها ، وتأثرت بسلوكها ، وتفسيره لهذا السلوك في الو اقع والخيال(") .

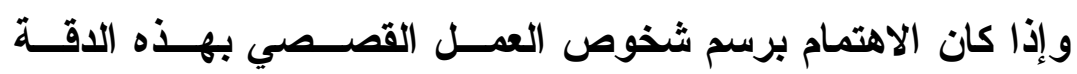

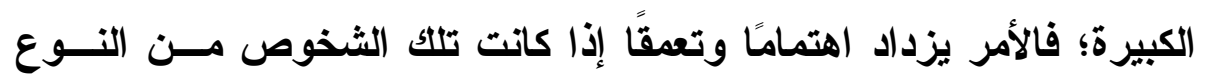

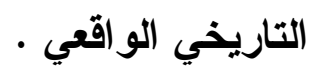

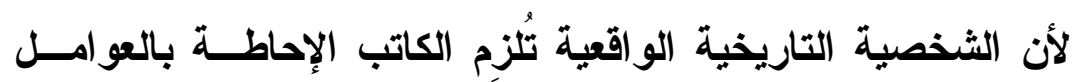

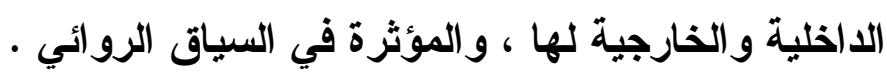

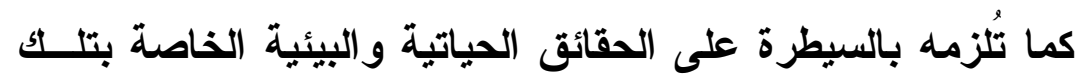

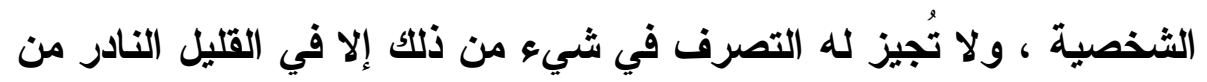

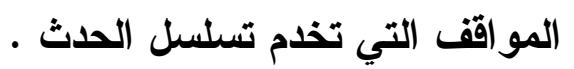

(') دراسات في النقا الرواية.د / طه وادي.ص ^^ ^وما بعدها.دار المعارف بالقاهرة.ط :

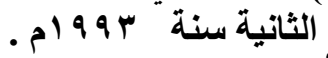

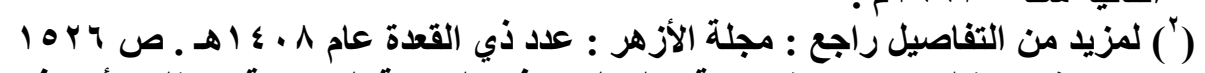

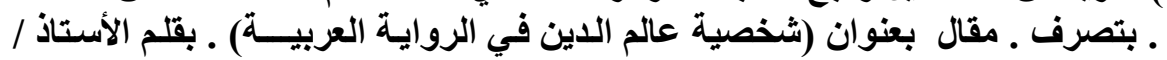




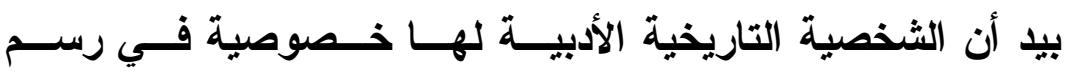

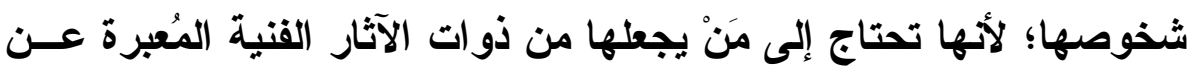

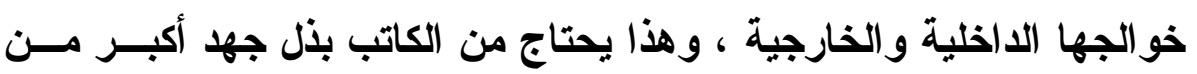

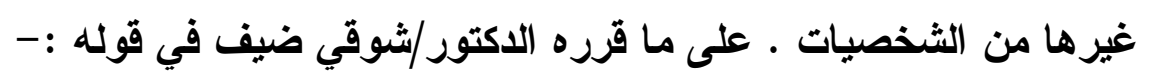

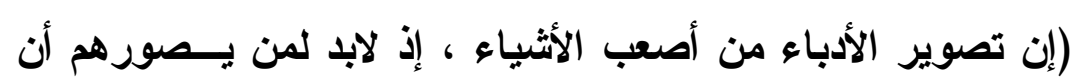

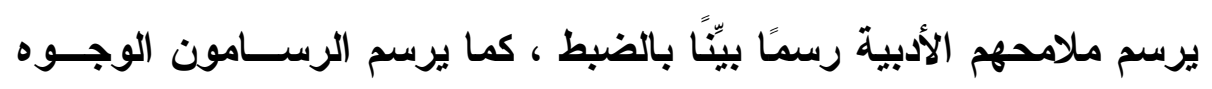

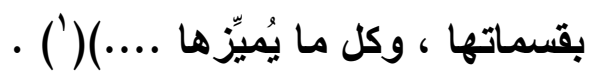

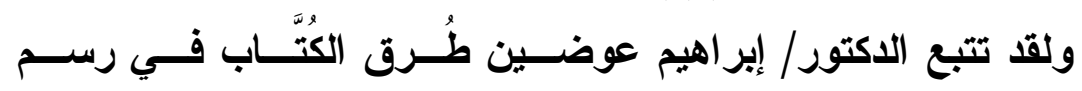

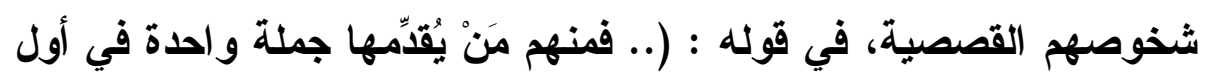

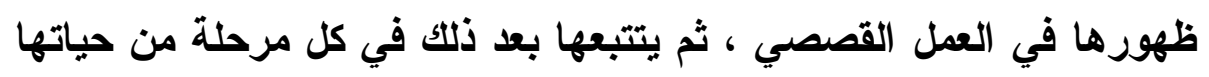

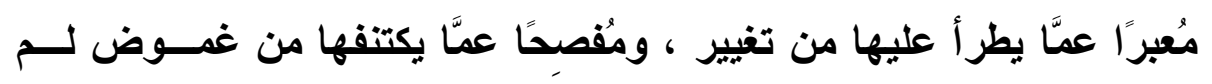

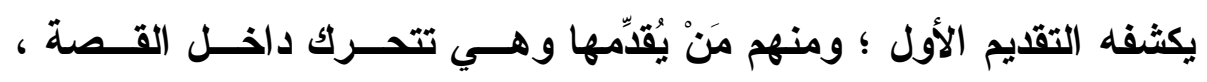

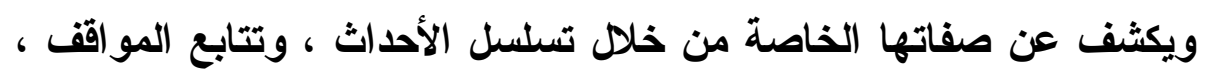

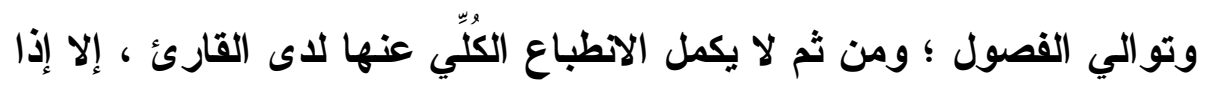

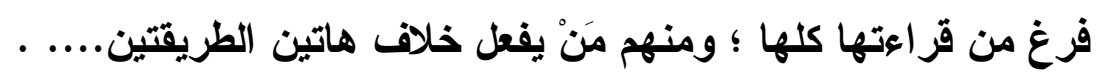

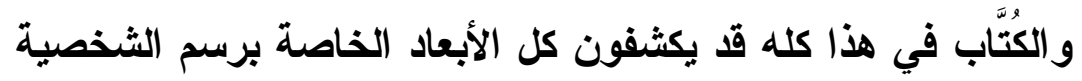

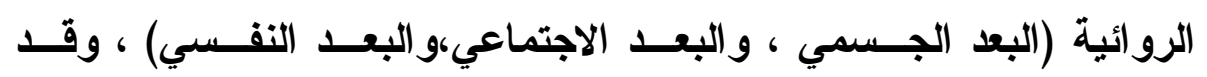

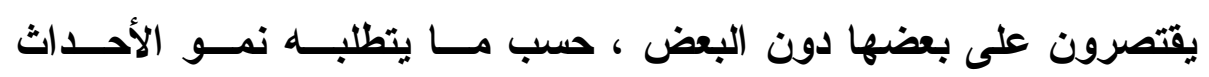

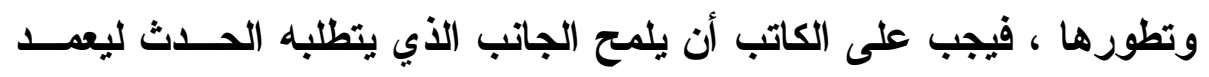

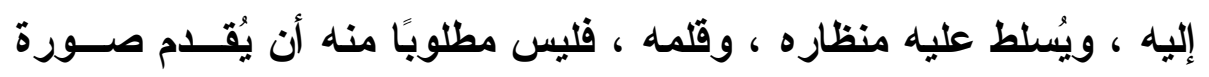

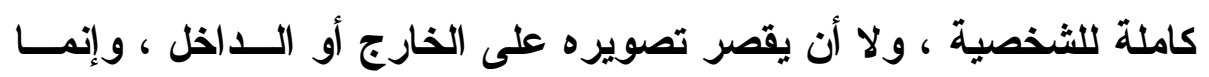
عليه أن يصور الجانب الذي تستدعيه القصة سواء كان خارجيًا ، أو داخليًا

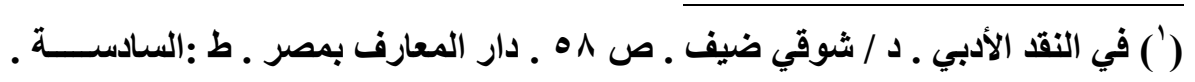


، وسواء كان جزئيًا أو كُليًَا ، وسواء كان واحدًا من جوانب الثخصية ، أو

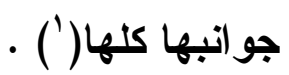

ولقد تتبع الجارم هذا النهج في رسم شخصياته القصصية التاريخية

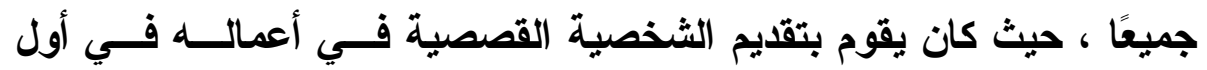
ظهورها في العمل الروائي ، ثم يتناول بعد ذلك فترات حياتها الاجتماعيسـة

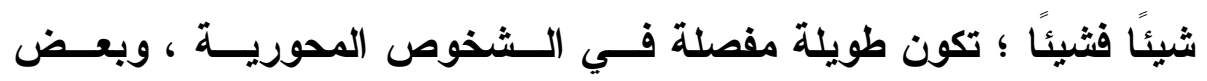
الثخوص المساعدة المهمة ، وتكون قصيرة وسريعة التناول في الثخوص

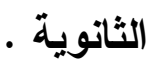

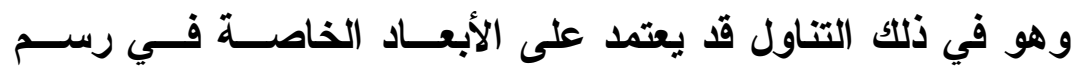

الثخوص جميعها (البعد الجسمي ، و البعد الاجتماعي ، و البعد النفسي).

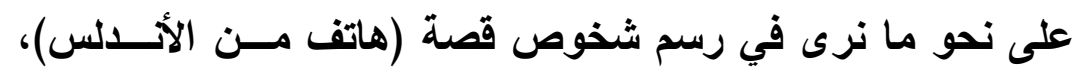

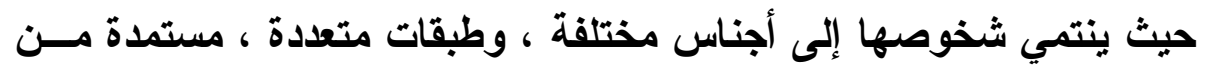

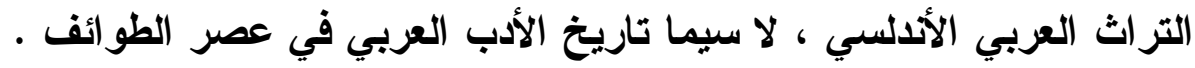
وكانت شخصيات القصة كالتالي :أ. الشفصية المهورية :-

هي شخصية (ابن زيدون) ، الثاعر الأدلسي الثهير ، وقد رسمها

الكاتب من خلال تضاعيف فترة كبيرة من حياته ، تصل إلى أربعين عامَّـا ،

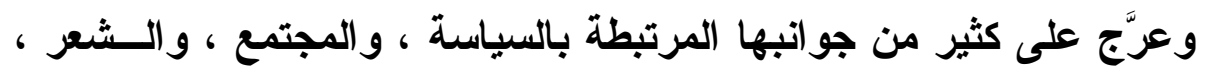

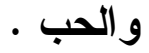

1 بـ ـ الشفوص المساعدة :-

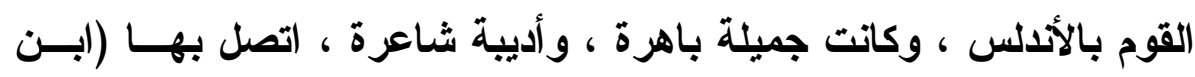

(') لمزيد من التفاصيل راجع : في الأدب العربي المعاصر ـ د / إبراهيم عوضين ـ ص

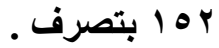


زيدون) ، من خلا منتداها الأدبي ، وقامت بينهما علاقة عاطفية عفيفة .

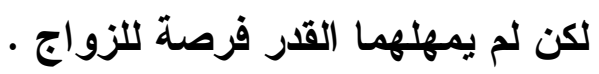

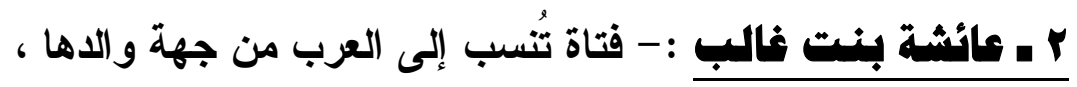

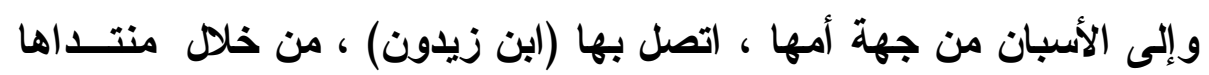

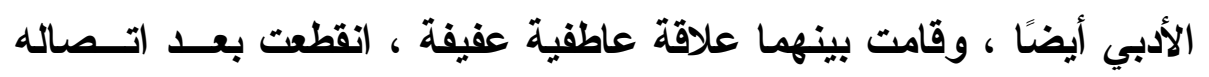

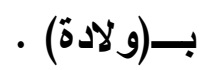

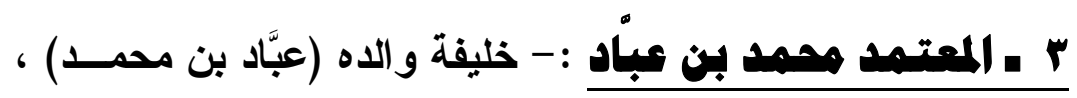

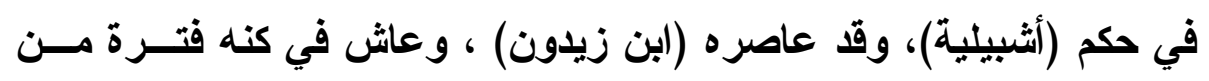

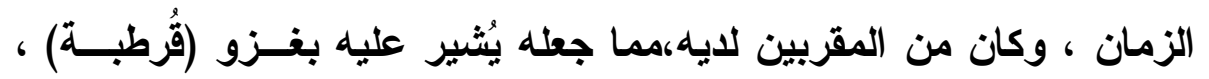
وضمها إلى حظيرته .

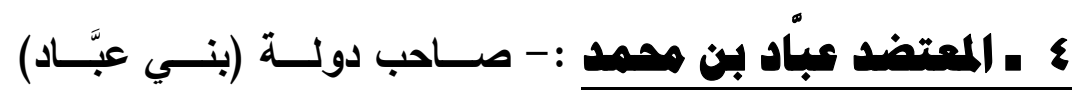

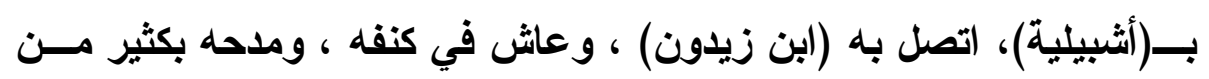

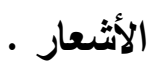

0

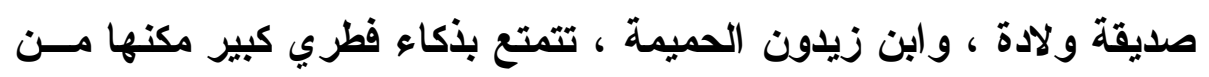
أن تكون الوسيط في اتصال ابن زيدون وولادة وتعارفهما .

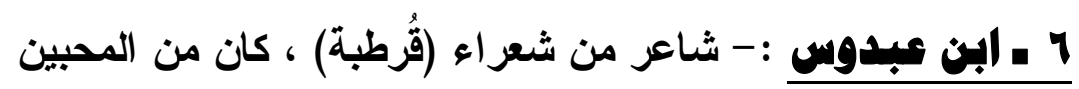

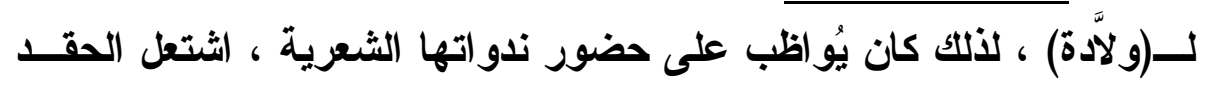

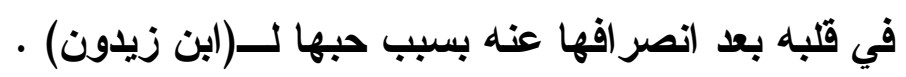

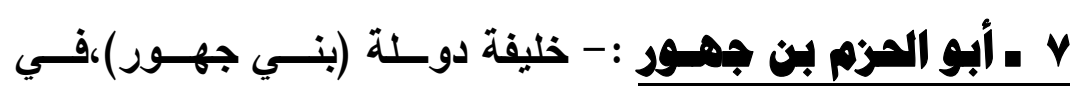

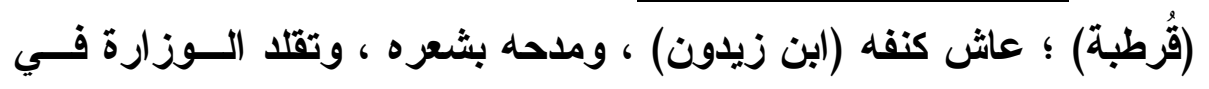

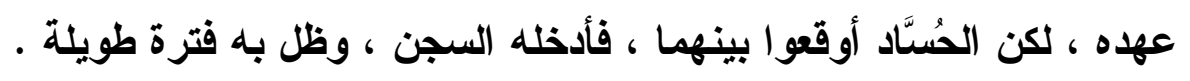




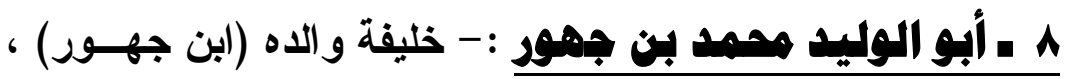

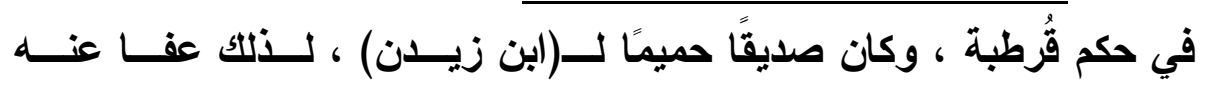
وأخرجه من السجن ، و أعاد له مكانته المفقودة .

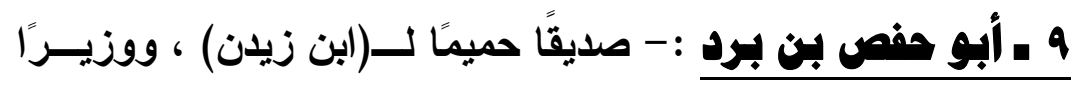

في دولة (بني جهور) ، وأحد المقربين من حاكمها (أبي حزم بن جهور) .

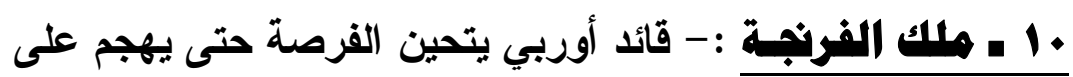

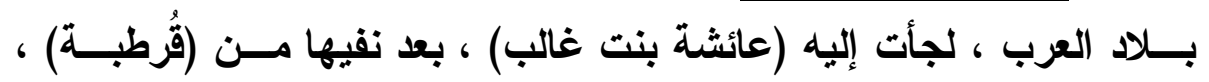

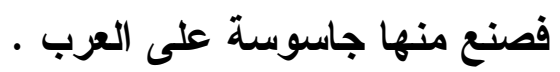
11 ـ أسبيتو : - جاسوس أسباني ، تخفَّى في صورة طالب جـاء لار اسة الطب على يد (ابن زُهُرٍ) . *********

و المتتبع لأحداث هذه القصة يُرك أن الثخصية المحورية ترتكـز

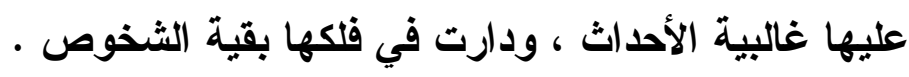

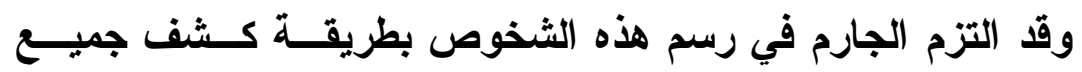

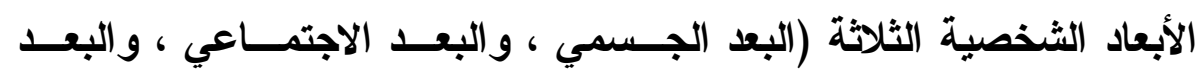
(النفسي) (لابعاد حيث رسم البعد الجسمي للثخصية المحورية في الصفحات الأولــى لــ

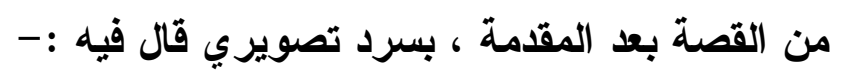

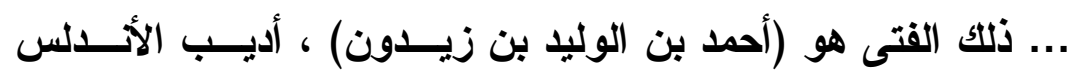

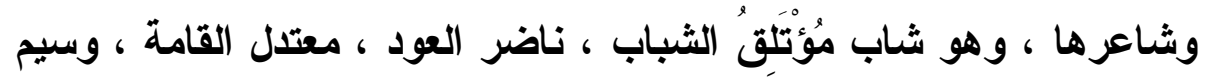

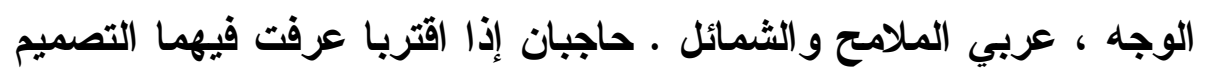

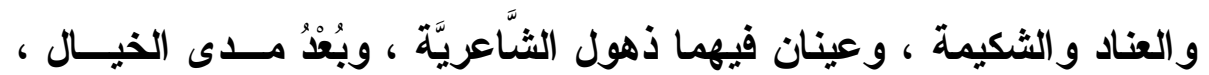

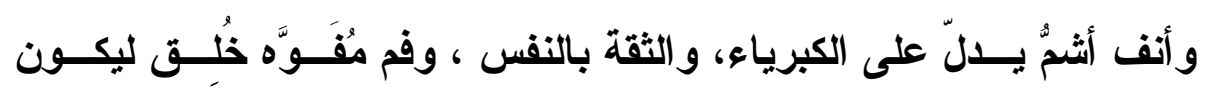
خَطيبًا . 
و(ابن زيدون) من بيت علم وأدب وثراء ونعمة ، كان أبـوه مـن

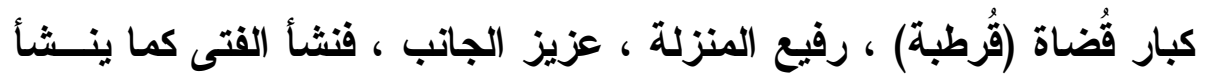

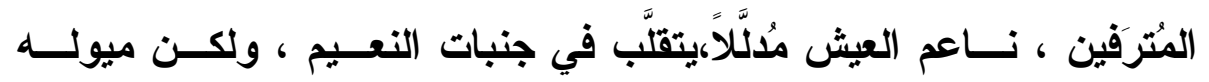

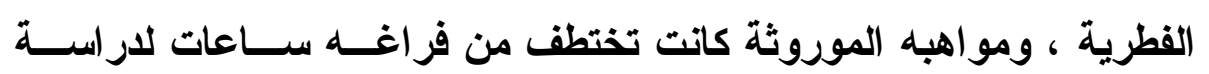

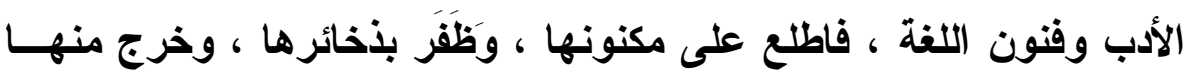

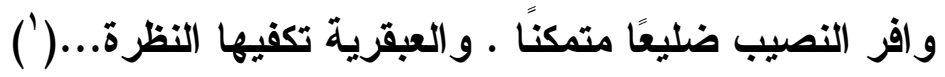

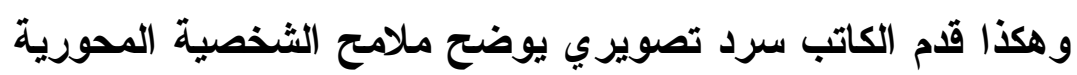

في القصة، حيث كثف أهم مقومات البُعد الثكلي لهيئتها ، دفعة واحدة .

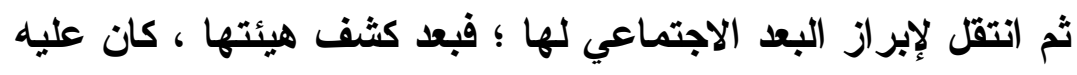

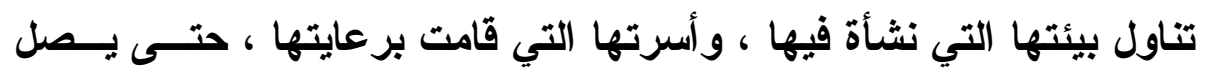

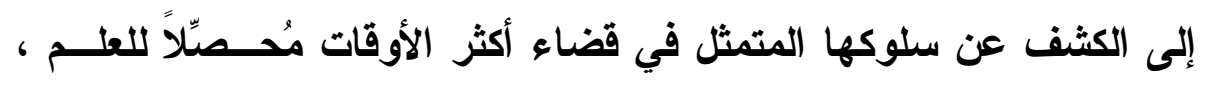

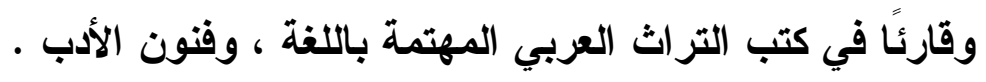

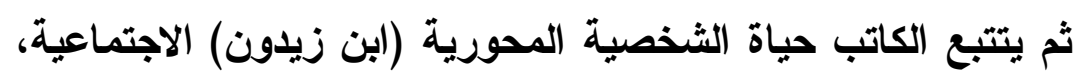

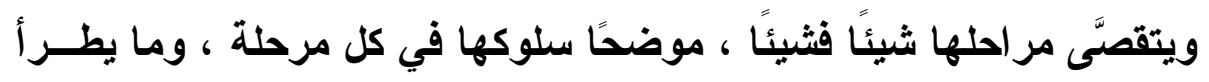

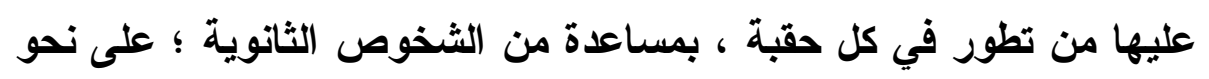
ما نرى في الآتي :ـ اتصال (ابن زيدون) بـ (ولادة بنت المُستكفي) ، عن طريق ندوة

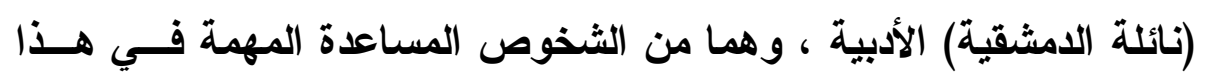

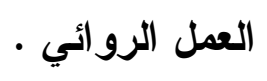

وقد كان لهاتين السياتين دور كبير في اتــصال (ابـن زيــدون) ،

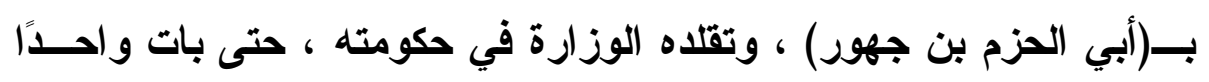

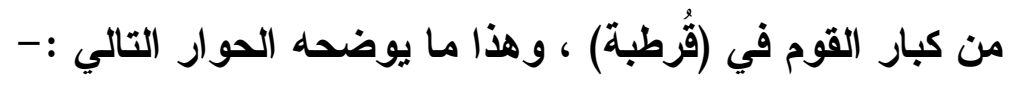

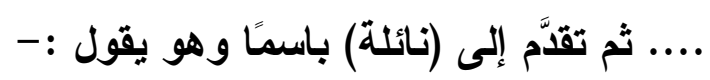

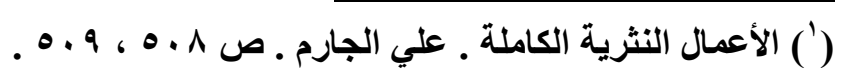


لقد أحسنت بي يا سيدتي،إذ مهدت لي سبيل الوصول إلى ذلك المُّكل

السَّماوي ، الأي كاتت تعجز عنه الأسباب ، وتتعثر الأوهام .

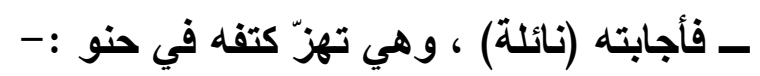

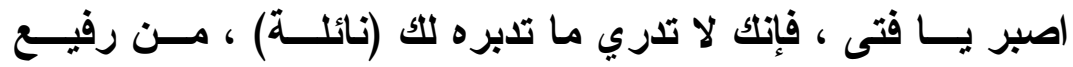

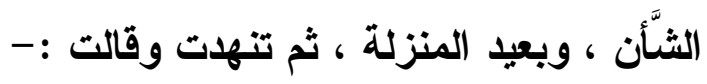

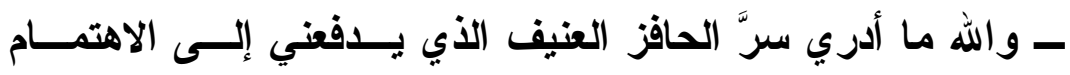

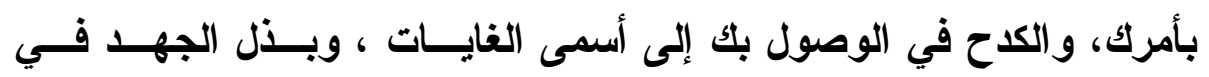

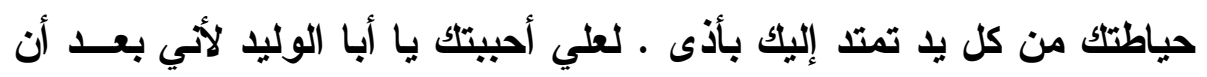

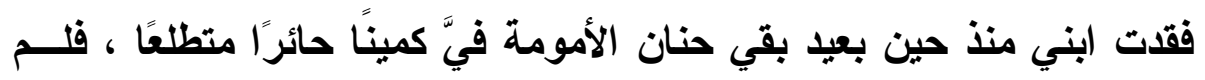

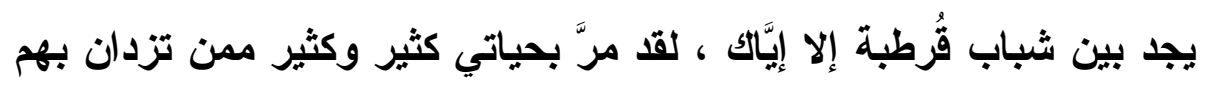

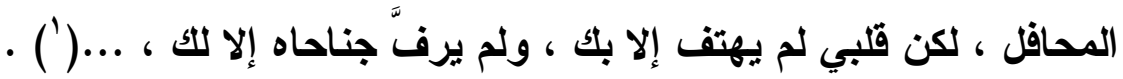

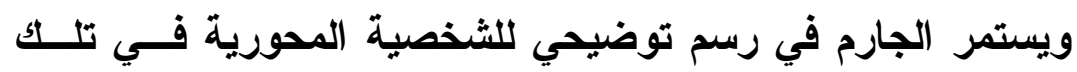

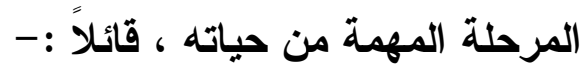

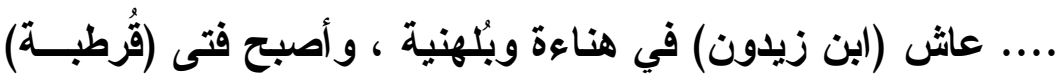

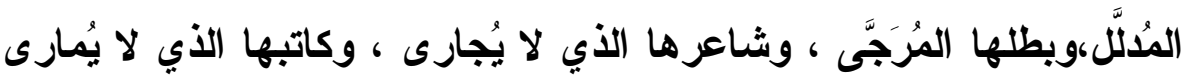

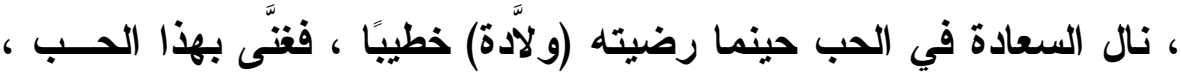

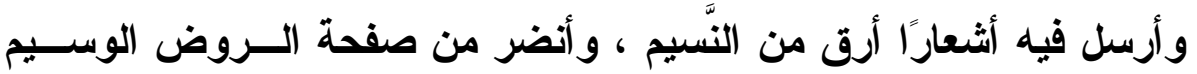

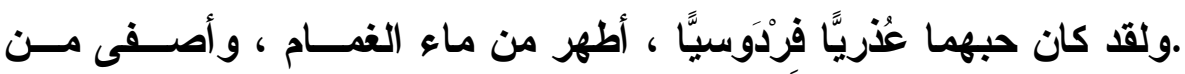

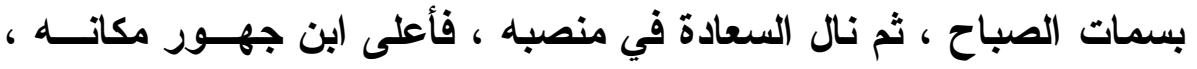

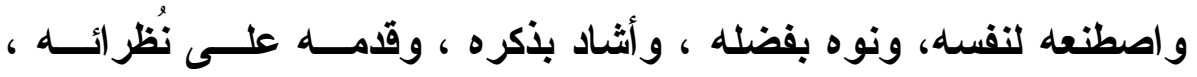

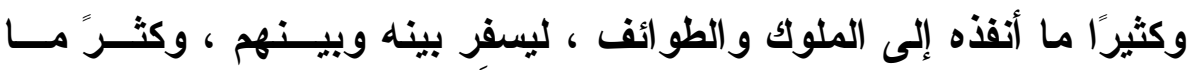
استكتبه الرسائل، التي تُضرب بلفئلاغتها الأمثال.

$$
\begin{aligned}
& \text { (') الأعمال النثرية الكاملة . علي الجارم ـ ص . ؛ ه . }
\end{aligned}
$$

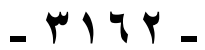


ولمَّا عظم إقبال الدنيا عليه ، كثر حاسدوه ، والناقمون منه ، فهـو

$$
\text { يقول لــ(ابن جهور) في قصيدة(') : :- }
$$

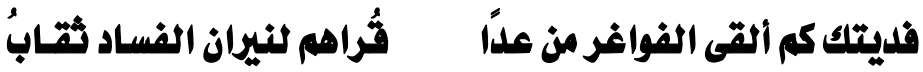

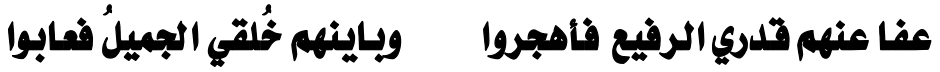

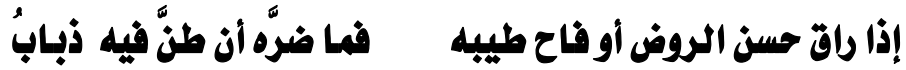

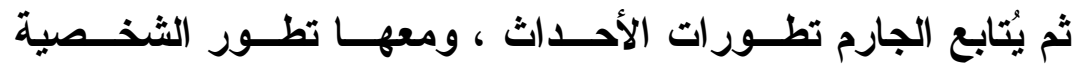

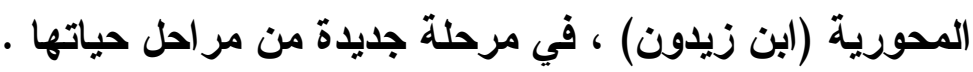

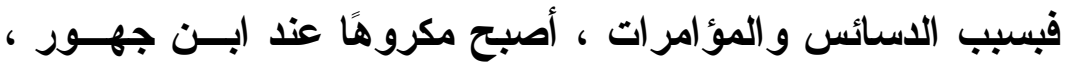

فأمر بالقبض عليه ، إيداعه السجن ـ وظل به مــدة طويلــة ، يُعـاني ألام

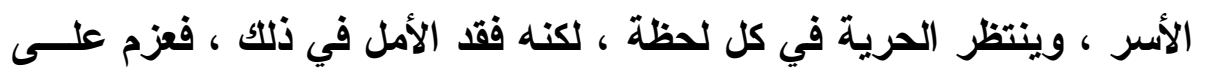

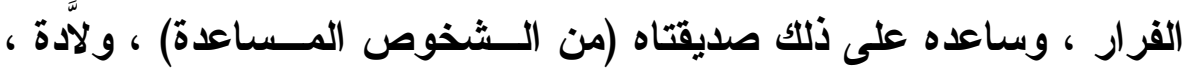

ونائلة .

فــر (ابن زيدون) من السجن ، واختفى فــي بيــت عجــوز فــي

(قُرطبة) ، حتى تم القبض عليه مرة ثانية .

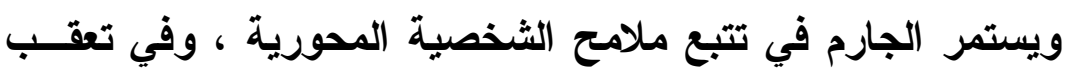

تطورها مع تطور الأحداث ، فهي تتقلب من حال إلى حال مع تقلب الأحداث

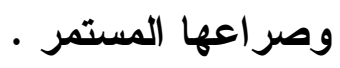

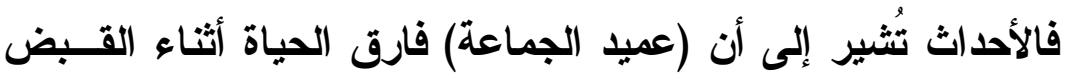

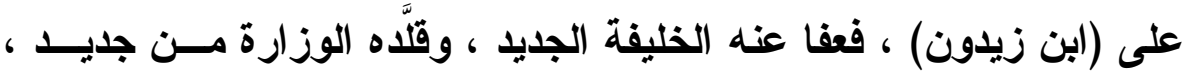

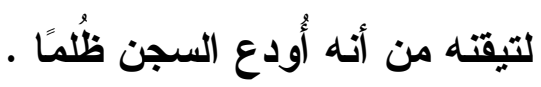

لقد تقلبت الأحداث مرة أخرى ، وتقلبت معهــا ملامــح الثخــصية

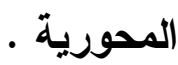


حيث شعر (ابن زيدون) ببدء تغير صاحبه ، فخاف علــى نفـسه ،

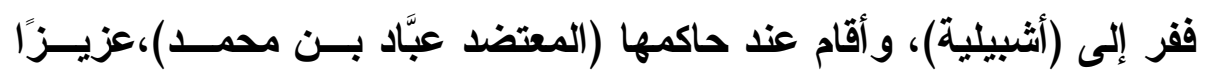

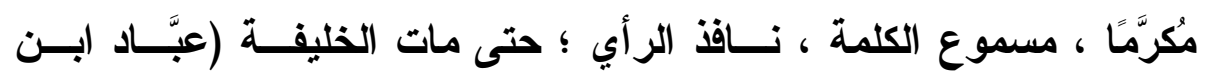

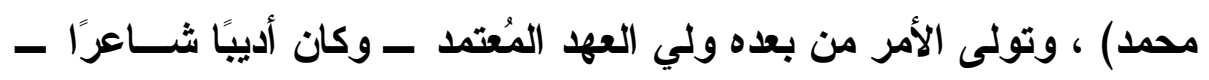
فأقبل على ابن زيلدون ، ووالى عليه نعــمه ، فملأ قلوب حاســديه عليـــه

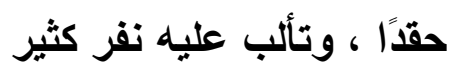

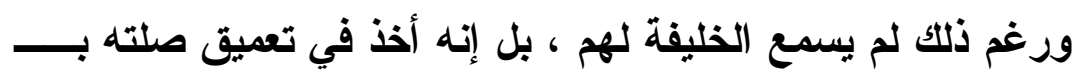

$$
\text { (ابن زيلون) }
$$

ويدور الفلك دورته ، وتقوى شكيمة (ابن زيدون) ، وبــات رفيــع

الشأن ، بعيد المنزلة مرة أخرى ، ويظل هكذا إلى نهاية حياته ....

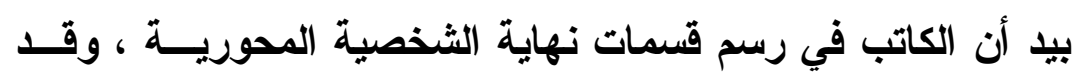

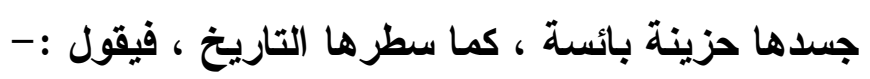

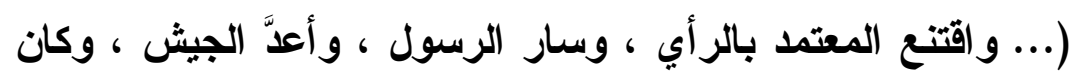

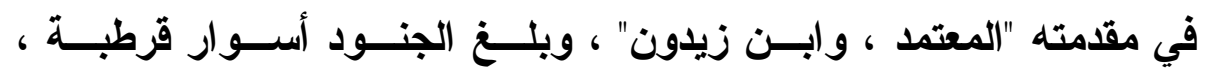

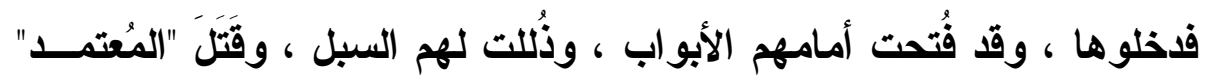
ابن عكاشة ، وأباد جيشه ، وظن عبد الملك أن الأمر اتتهى عند هذا الحد ،

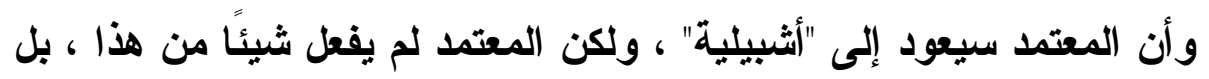
قبض على عبد الملك ، وعلى أخوته ، وسائر أهل بيته ، وأودعهم السجون

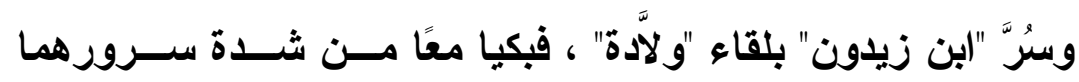

باللقاء ،وبكي معًا لأن "نائلة" لم تكن معهما بعد أن عادت إليهما الأيام .

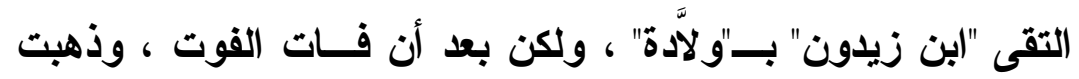

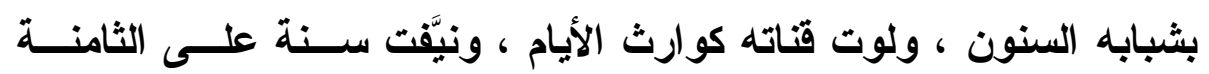

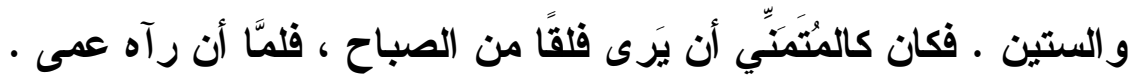




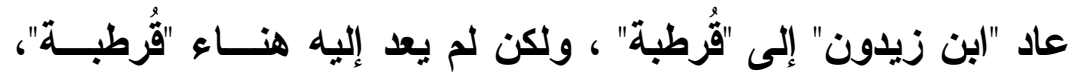

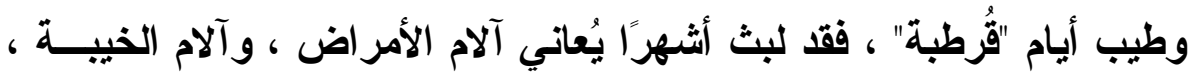

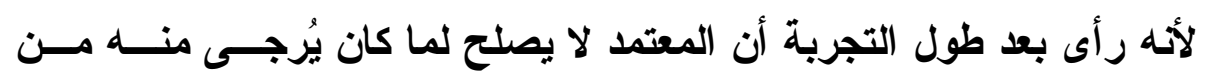

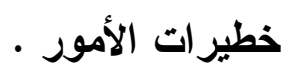

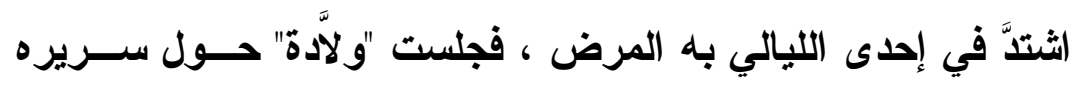

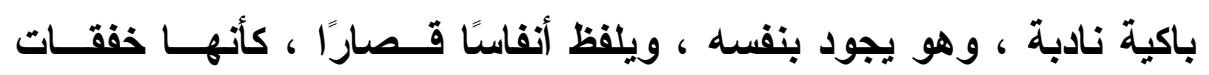

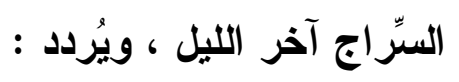

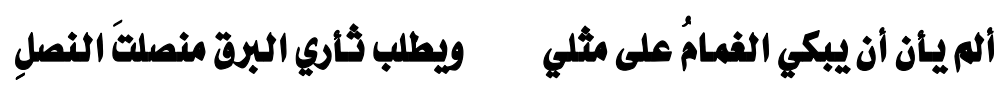

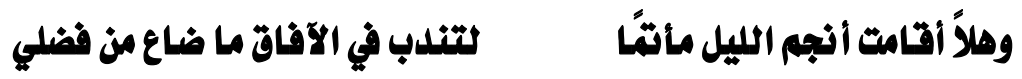

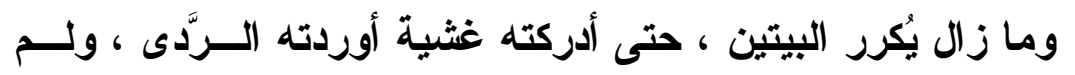

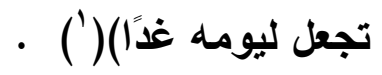
و هكذا الهتم الكاتب برسم الثخصية المحورية مـن خــلا إضــاءة

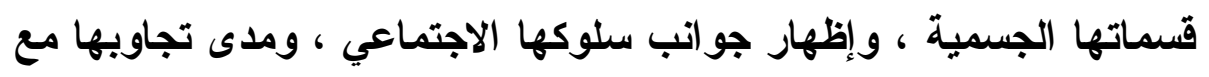
تطور الأحداث ونموها .

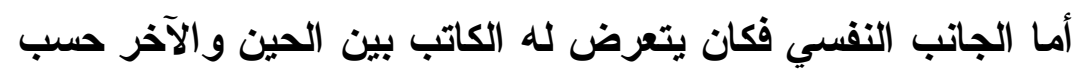

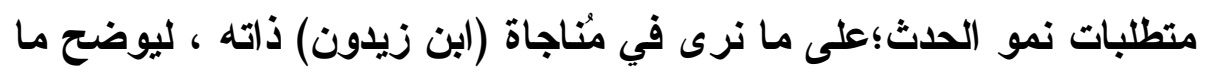
يدور في مكنون نفسه من خو الج الإشراق ، أو الغيوم .

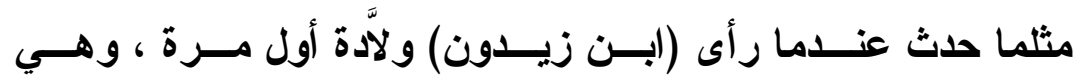

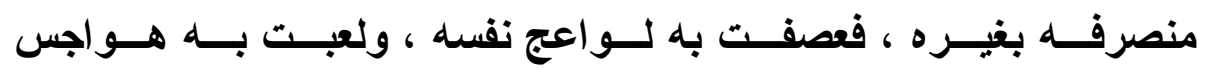
وجداتـه ... فقال :-

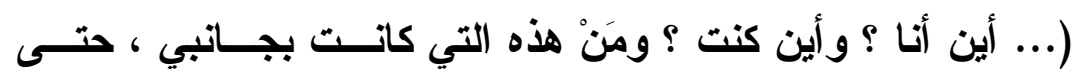

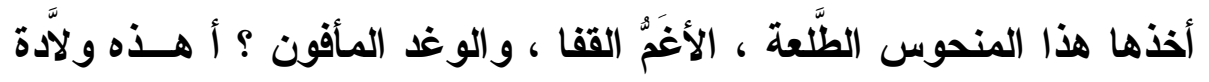

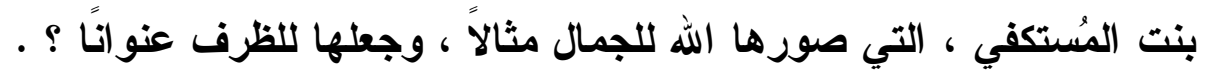

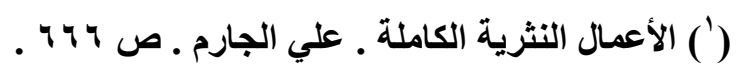

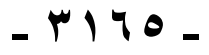




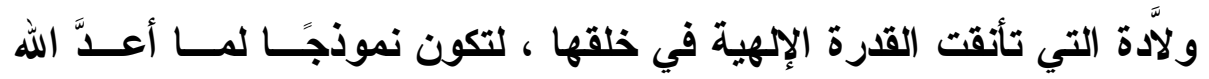

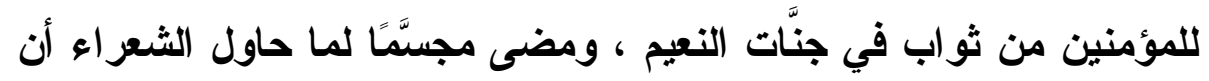

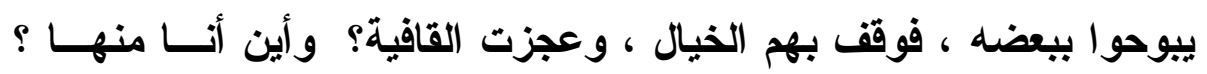

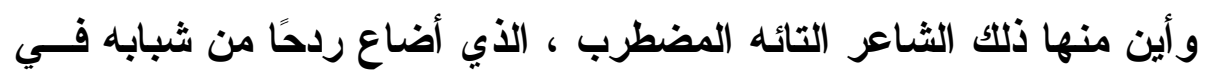

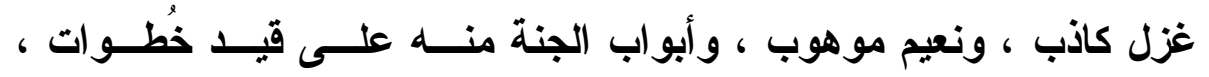

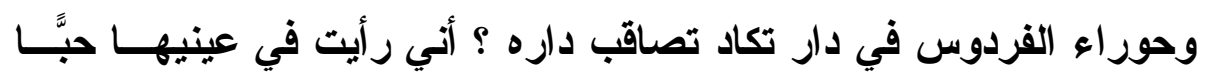

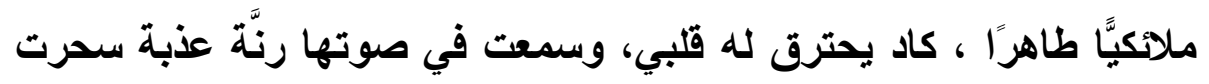

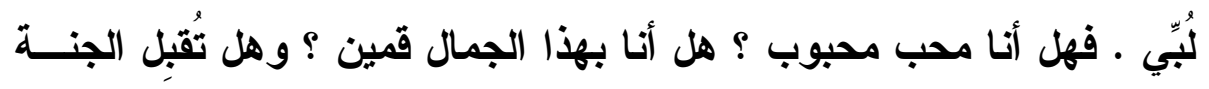

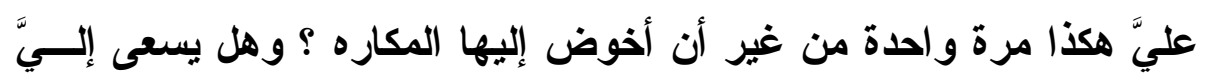

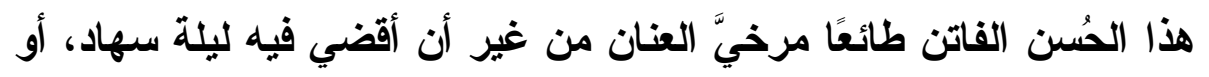

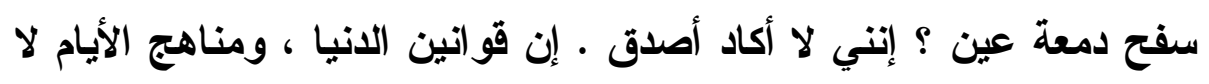

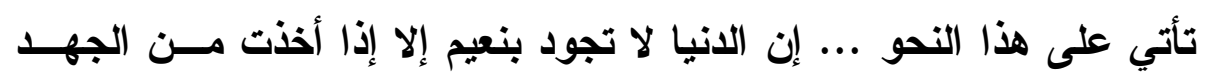

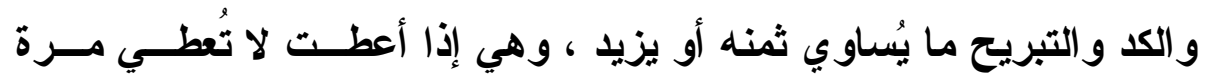

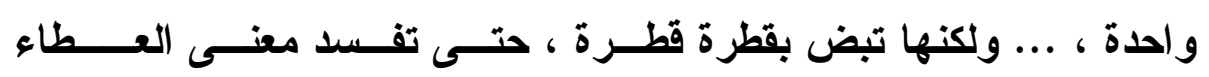

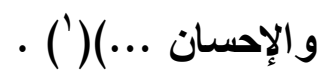

فقد رسم الجارم في هذه الفقرة الجانب النفسي للثخصية المحورية

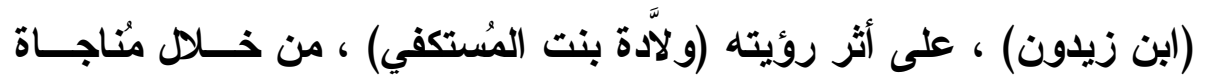
ذاتية ، ذهبت به كل مذهب في شأن (ولَّاّة) .

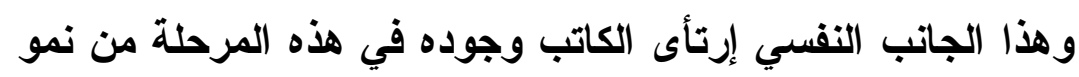

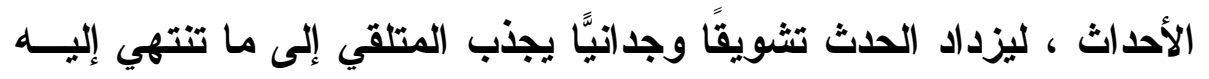
الاثتجارات الوجدانية . أضف إلى ذلك بعض التضاعيف النفسية ، التي تلذخل الكاتــب فـــي تصويرها ، عن طريق السرد القصصي ، بحيث يكون تحليلاً نفسيًّا سـريعًا

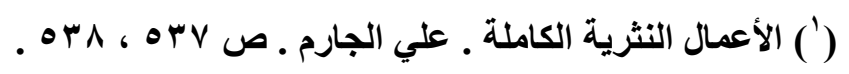


مركًَّا يُسـاهم في رسم الثخصية (المحورية) ، ويبرز تطورها مــع تطــور الأحداث . مركزاث

من ذلك مـا قدمه الجارم عن صــورة خوالـــــج (ابـن زيســدون)

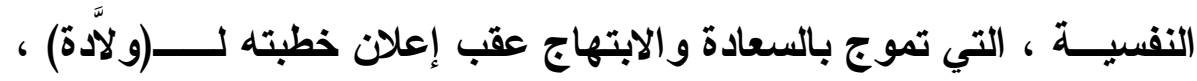

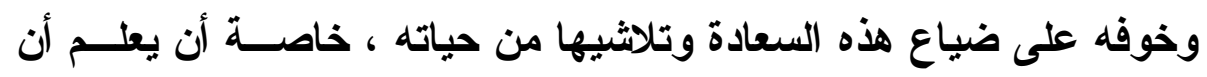

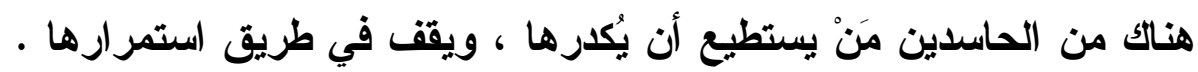

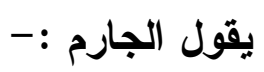

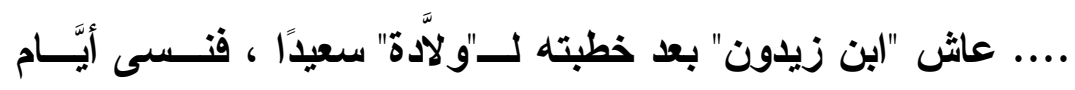

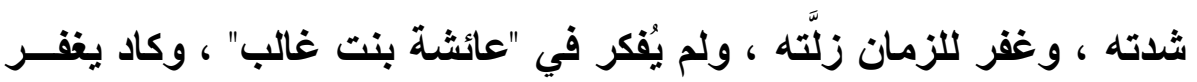

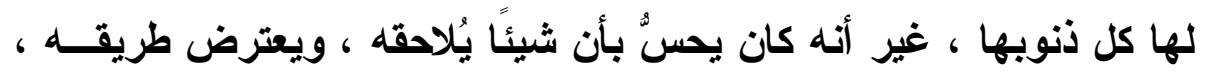

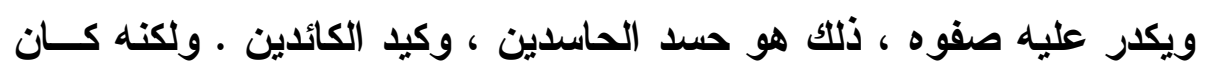

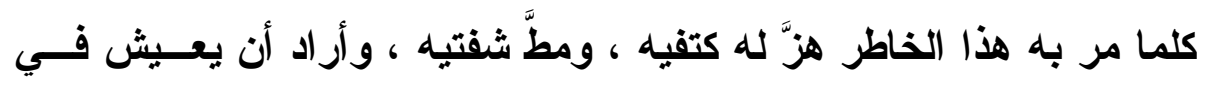

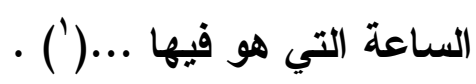

ومن تضاعيف الثخصية المحورية النفسية ، ما قدمه الكاتب عنها

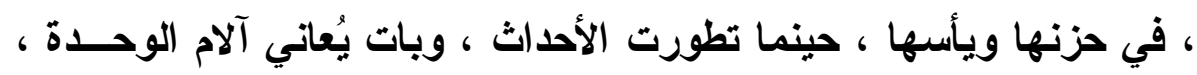

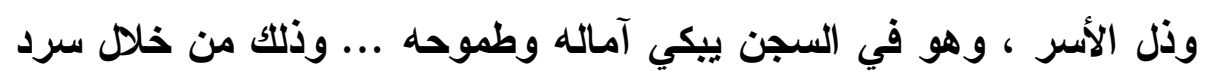

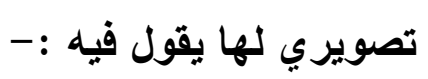

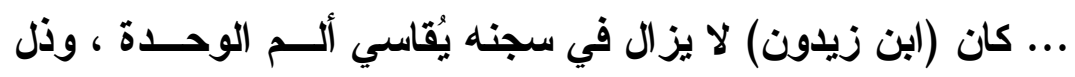

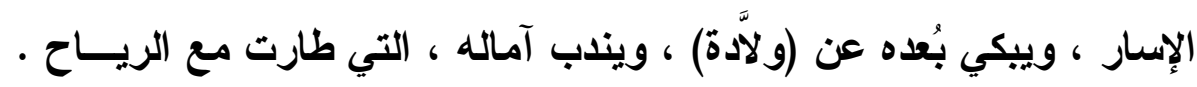

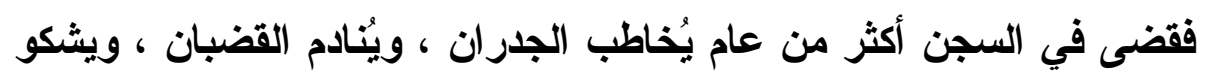

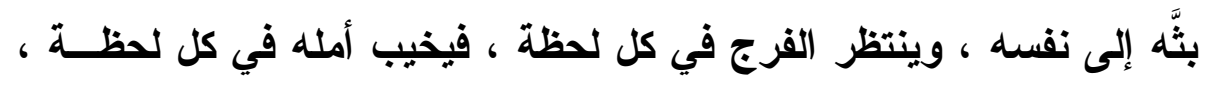

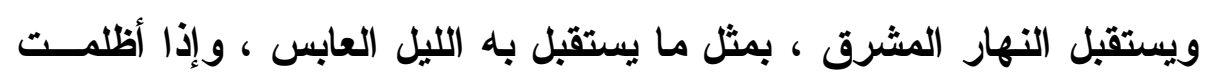

(') الأعمال النثرية الكاملة ـ علي الجارم ـ ص 9 (') .

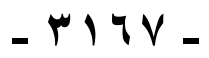


نفس المر فماذا يُقيد الضياء ؟ وسعادة الإنسان وشقاؤه من نفـسه التــي بين جنبيه ، فقد تريه الأمن خوفًا ، وقد تريه البؤس نعيمًا ....(') . . . . ولم تقف طريقة الكاتب في التدخل التصويري التفـسي المُكثَّفـ ، الأي يقف بالمتلقي على تضاعيف وجدان الشخصية الداخلية والخارجيــة، عند حـ الشخصية المحورية ، بل تجاوز ذلك إلى الشخــصيات المـسـاعدة كذلك ، كل حسب دوره المُحدد في نمو الأحداث وتسلسلها . وهكا كان الجارم يرسم شخصيات قصصه التاريخية متتبعًا المنهج التقليدي القائم على البعد الشكلي ، والاجتماعي ، و النفسي •

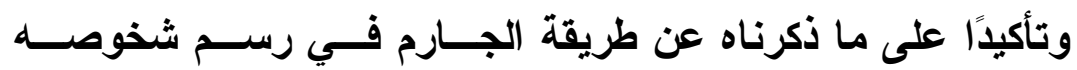

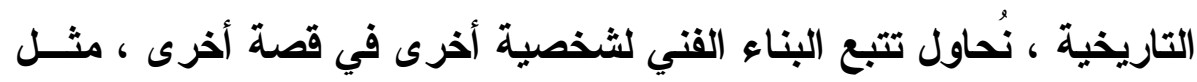
(فارس بني حمدان) · حيث بدأها بتقديم سرد تصويري للشخصية ، استخدم

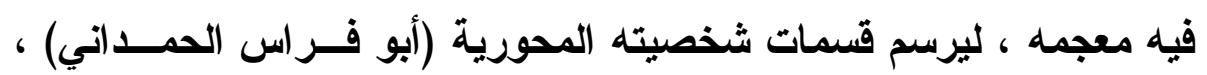
بطريقة تُبنى على إيقاف الحركة الدرامية ، وتقديم سرد تصويري للثخصية عند بلد ظهورها ، ثم استكمالها فيما بعد .

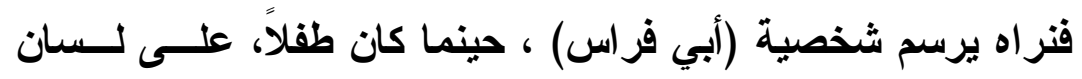

$$
\text { أخيه بقوله :- }
$$

.... إن هذا الطقل أعجوبة الأعاجيب ! ، إنه وهــو فـي الـسـابعة

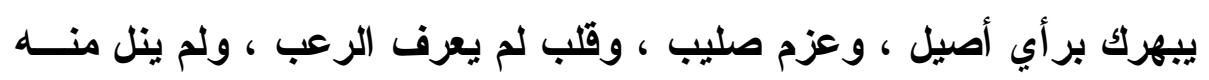

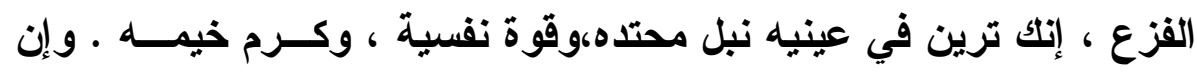

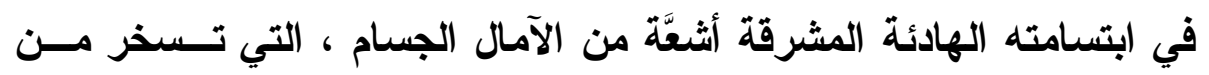

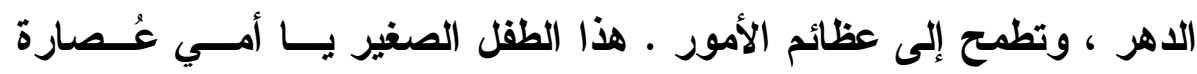

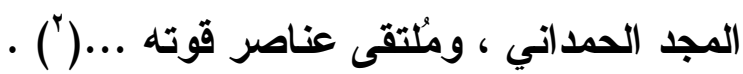


ثم يعود الكاتب في موضع آخر يرسم تطــورات تلــــ الثخـصية الجسمية ، من خلا تطور الأحداث المصاحبة له ـ حيث يقول :-

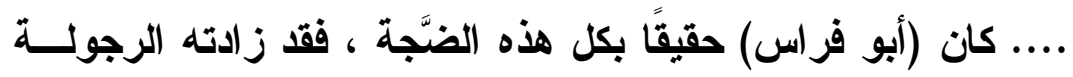

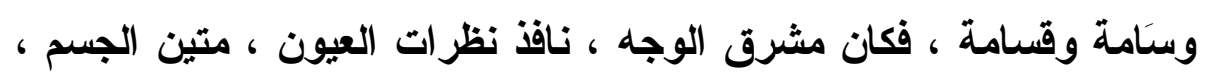

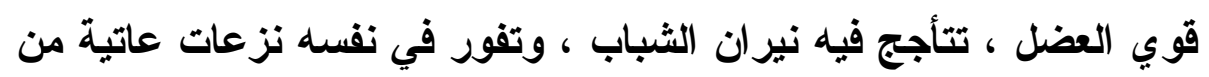

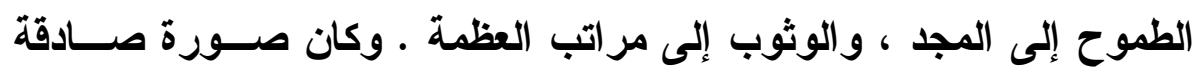

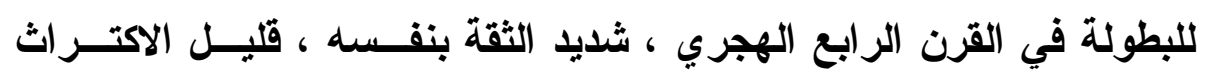

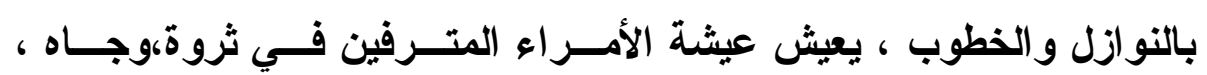

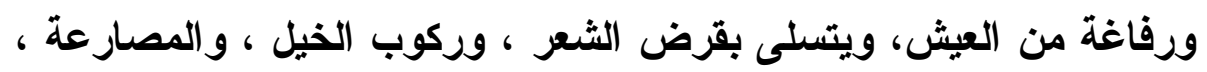

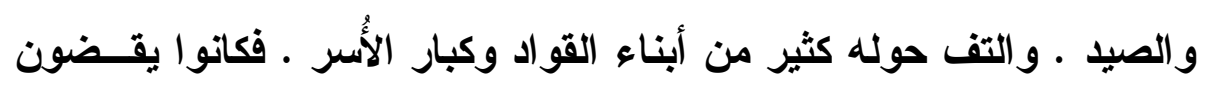

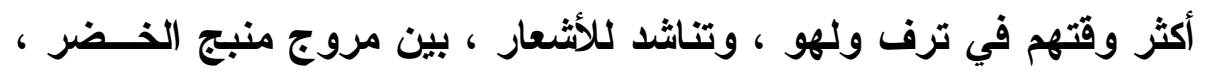

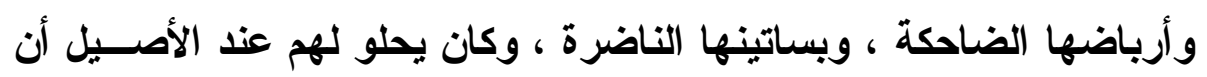

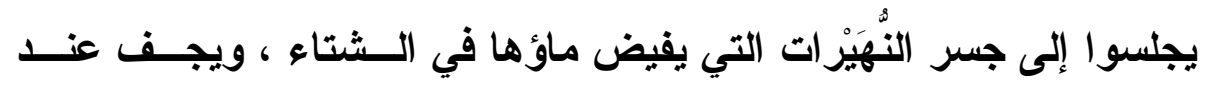

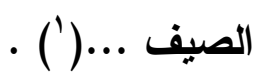

و هكذا رسم الجارم صورة توضح قسمات الثخــصية المحوريـة ،

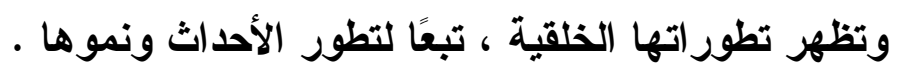

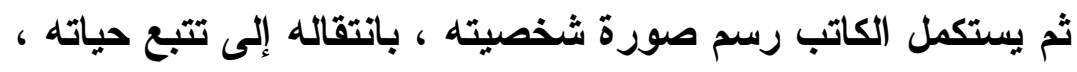

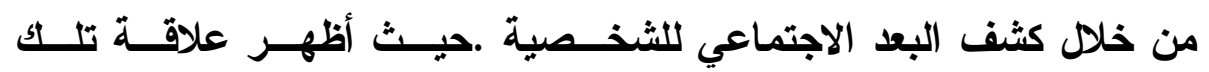

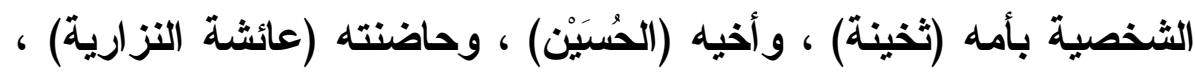

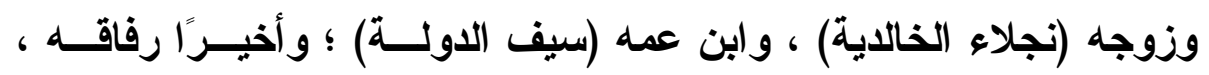

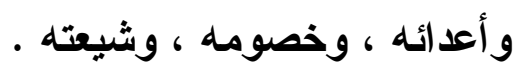

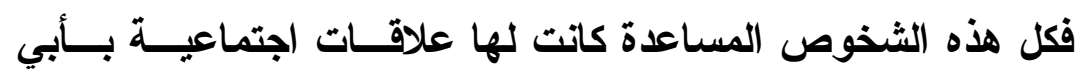
فراس، أظهرها الكاتب ليكثف البعد الاجتماعي للثخصية المحورية . 
وهكذا ركز الجارم في بناء القصة الفني للشخصية علـى البعـدين

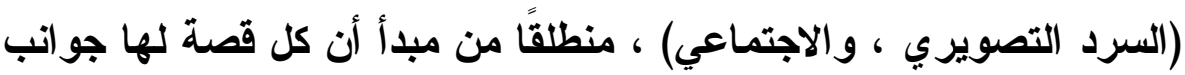

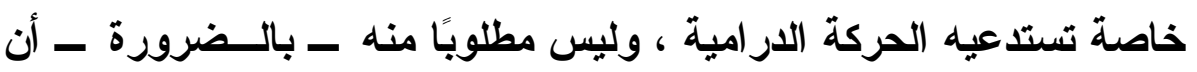

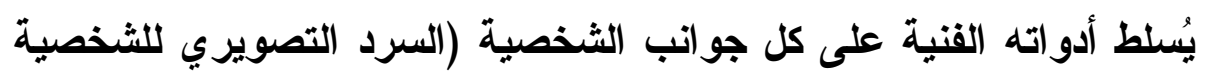

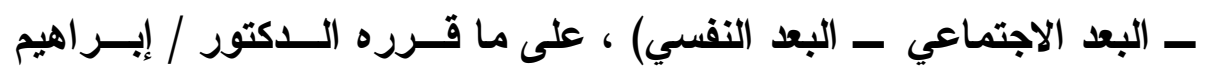

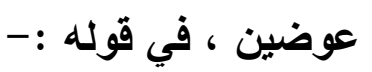

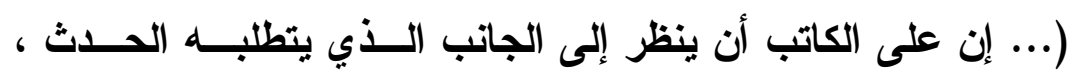

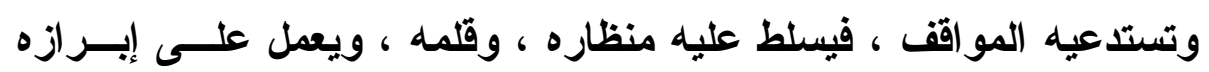

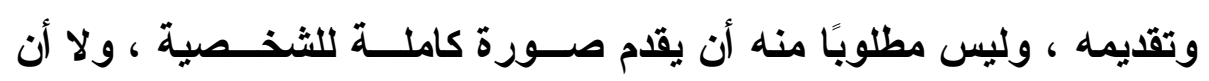

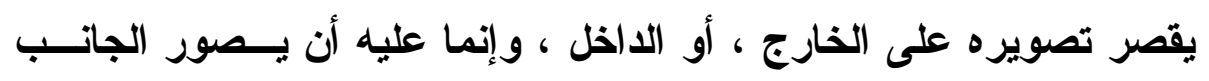

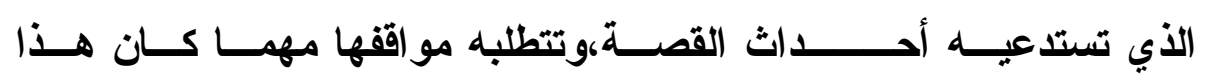

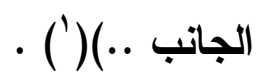

على أن اختيار الثخوص الملايمة للأحداث يختلف من أديب لآخر ،

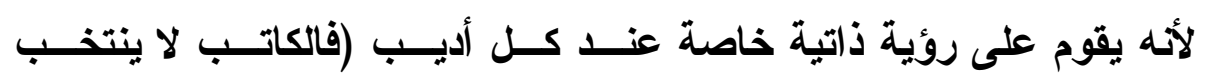

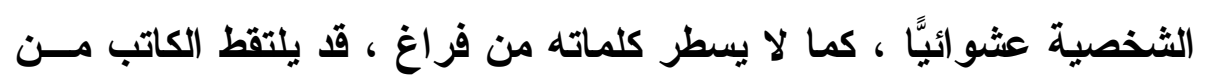

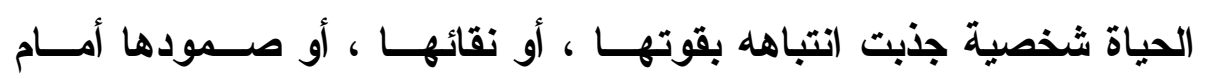

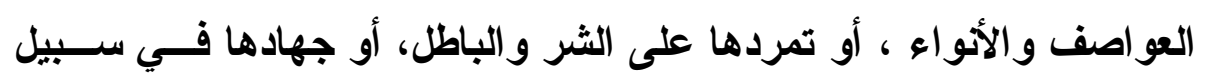

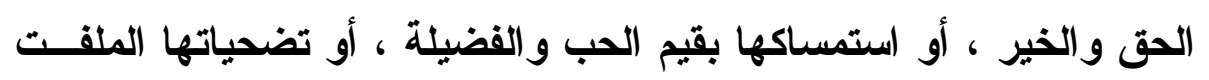

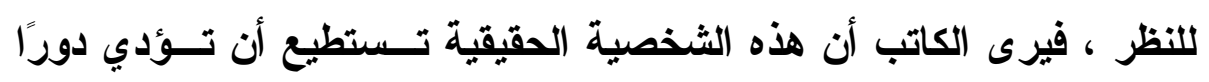

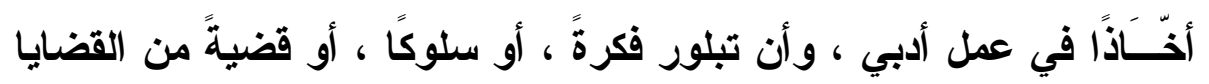

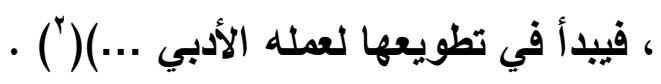

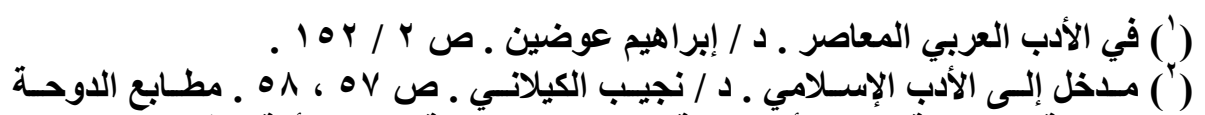

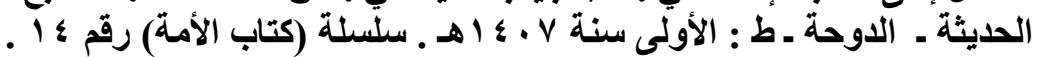


وتطويع الثخوص في العمل القصصي يختلف من كاتب لأخر ، من

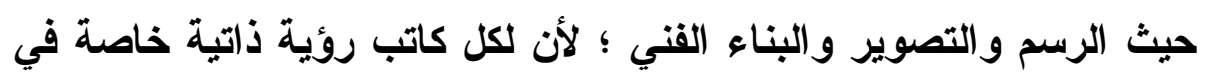

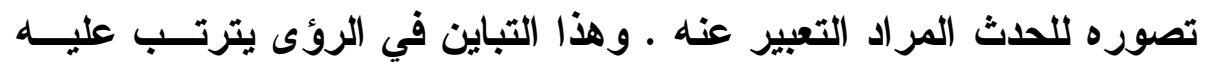
الاختلاف في رسم الثخوص ، (فكل روائي يحتاج لتصوير البشر وتجسيد

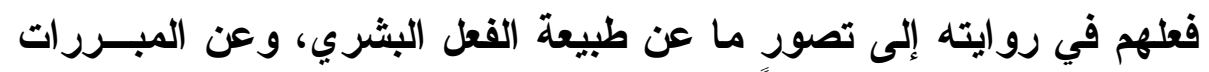

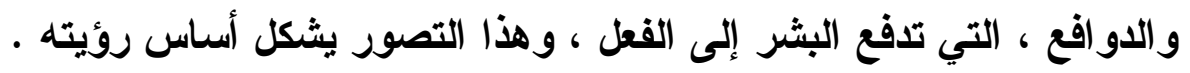

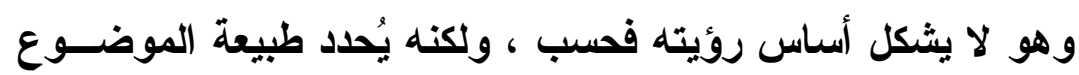

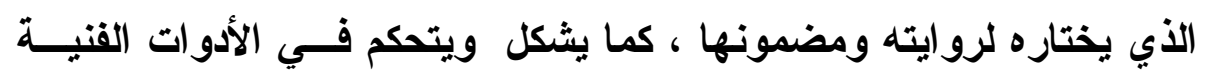
التي

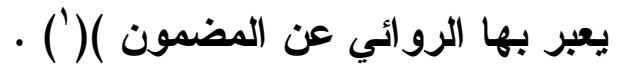

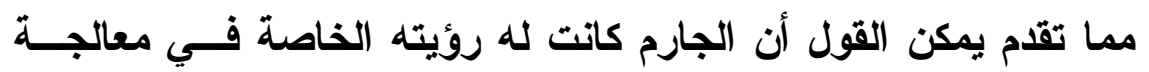

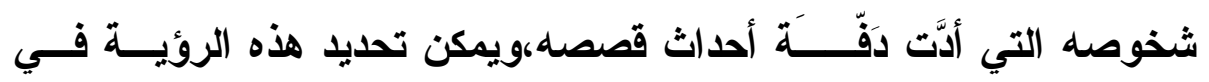
الآتي :1

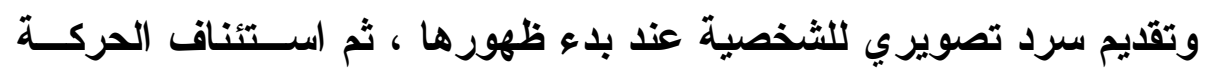

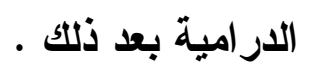

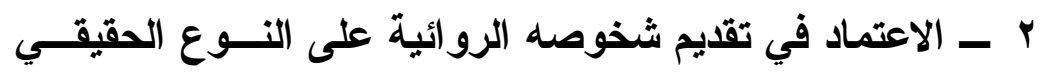
التسجيلي ، موجودة في التاريخ العربي والإسلاهي المجيد ، وقد ذاع صيتها

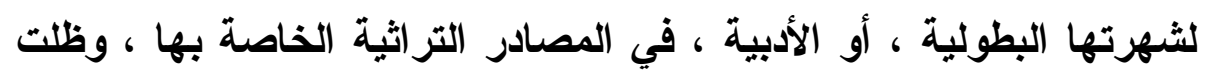

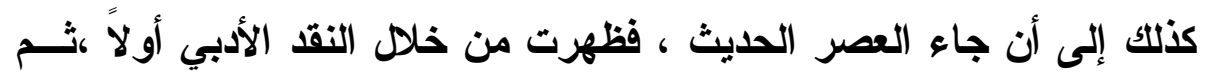

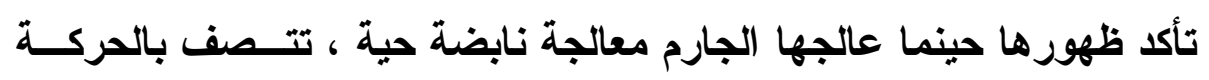

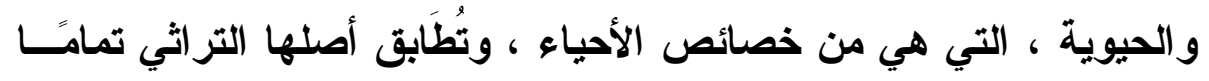

(') (الرؤية والأداة (نجيب محفوظ) ـ د / عبد المحسن طه بدر ـ ص VI ا ـ دار المعارف بالقاهرة . ط : الثالثة 
بتمام ، ولا تفترق عنه في شيء ، اللهم إلا في القليـلـل النـــادر ، الــــي لا لا يتعارض مع الحقيقة التاريخية ، ويخدم في الوقت ذاته الحركة الفنية فئهي

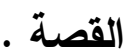

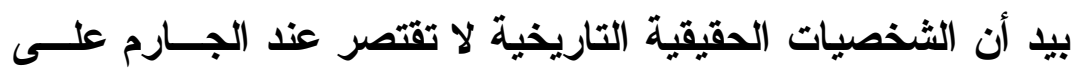

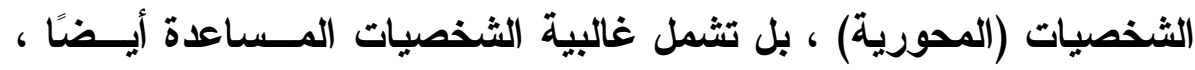

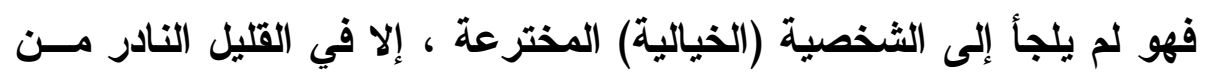

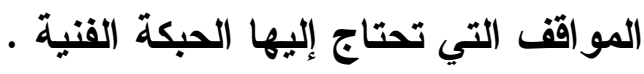

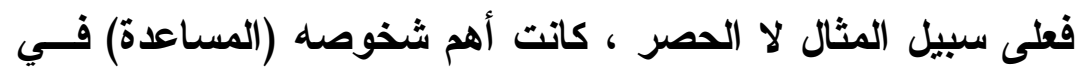

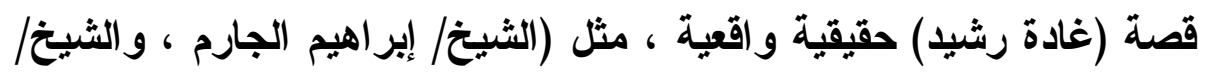

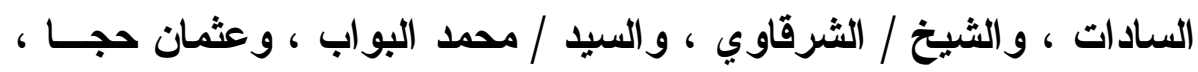
ونابليون ، وكليير ، ومينو ، و الحلبي ، وغيرهم ..) .

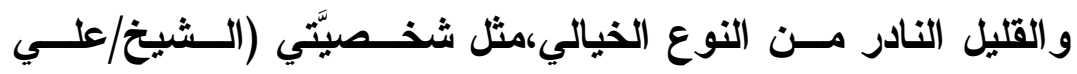

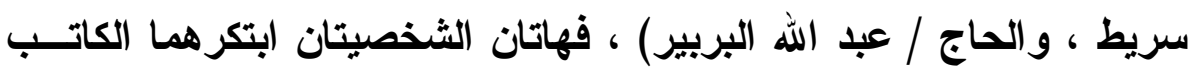

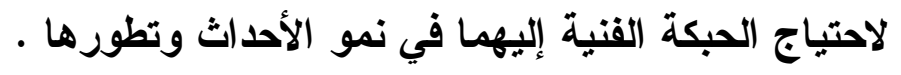

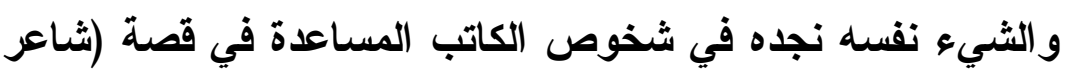

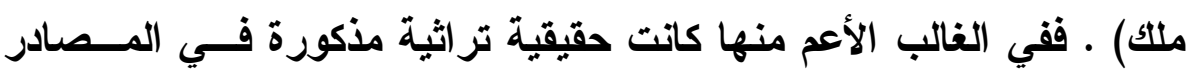

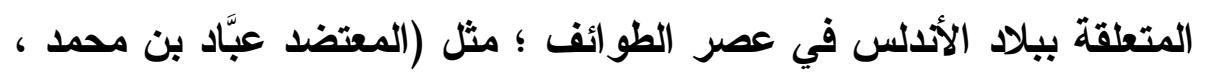

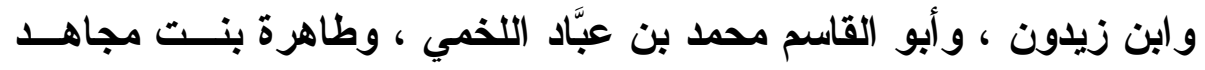

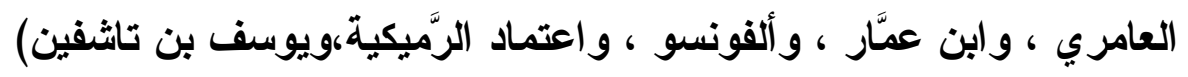

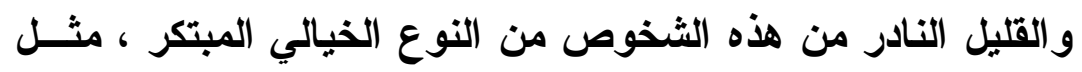

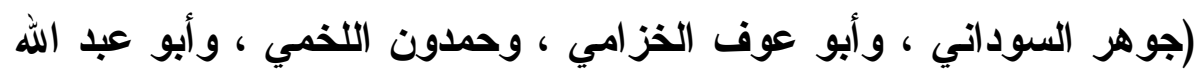

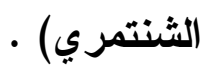
وهؤلاء جميعًا إما من العبيد ، أو العسس ، أو أصحاب البريـــ ، أو 
واهتمام الكاتب بهذا النوع من الثخوص (الحقيقية التراثية) يعنـي

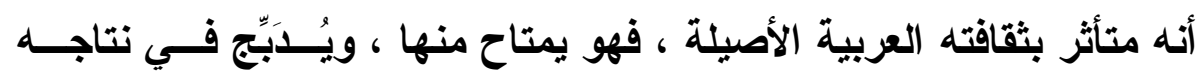

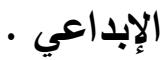

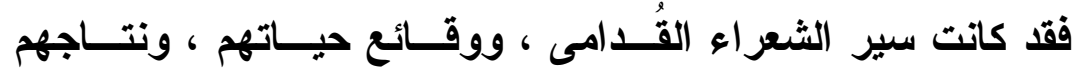

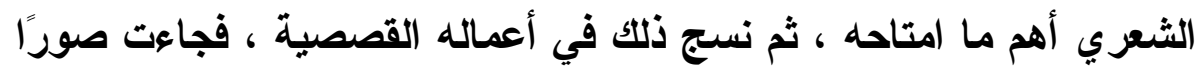

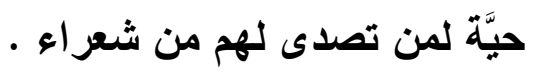

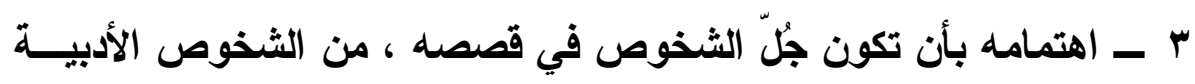

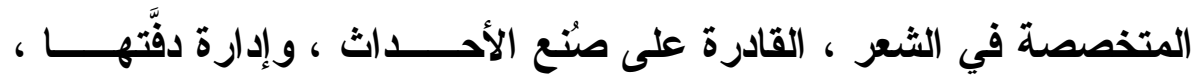

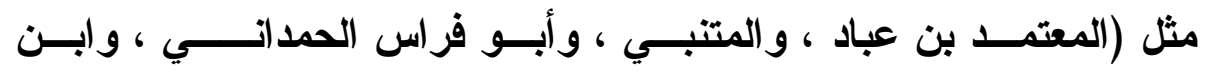

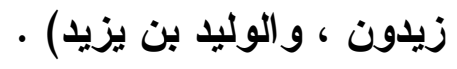

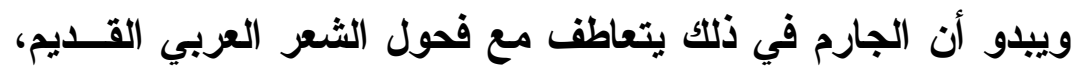

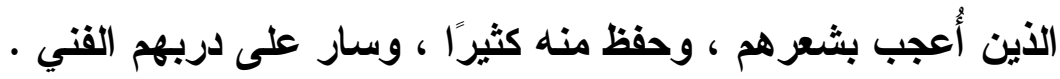

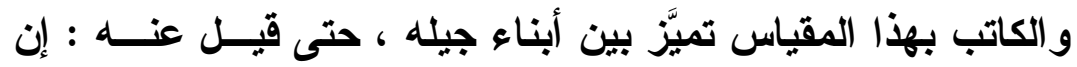
ذلك من إنجاز اته ، ومما يُحسب له في مسيرة القصة التاريخيــة الحديثـة

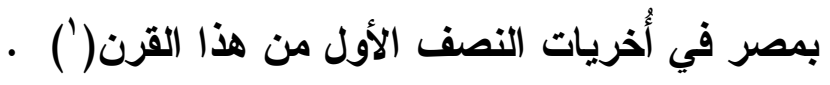

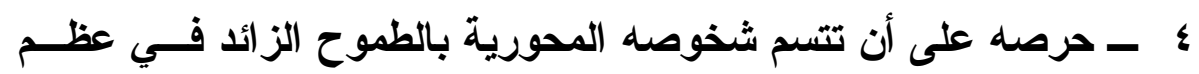

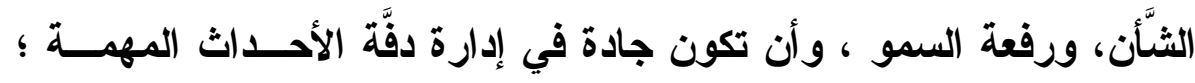

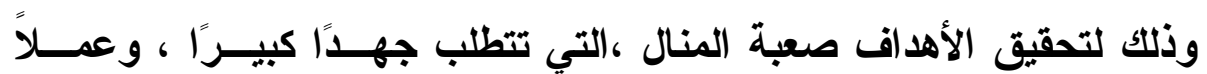

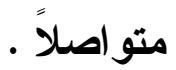

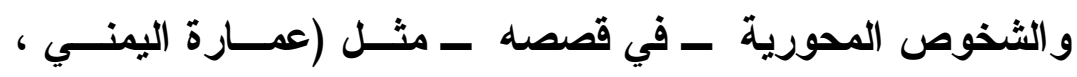

وزبيدة بنت البواب، والوليد بن يزيد ، وأبو الطيب المتببي ، وأبو فرسل فئه ،

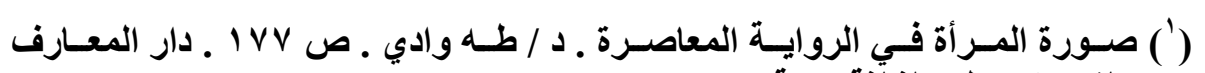

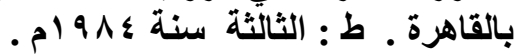


و ابن زيدون ، وغيرهم)، من النوع المجد المثابر ، الذي يتسم بالطموح إلى

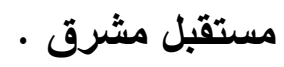

على نحو ما نرى في شخـصية الــشاعر الكبيـر (أبــي الطيـبـ

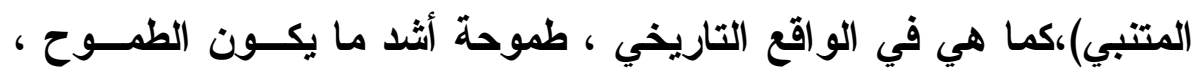

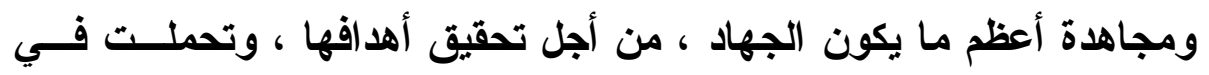

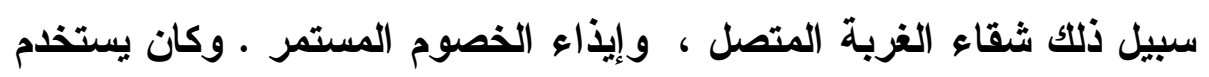

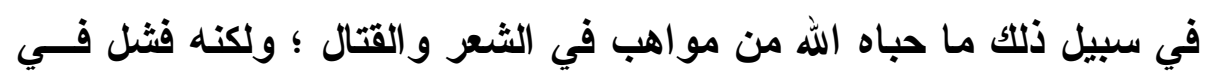

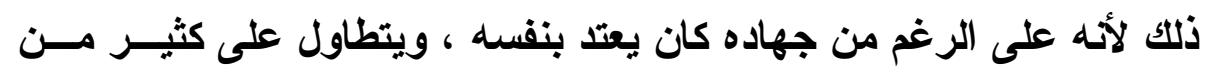

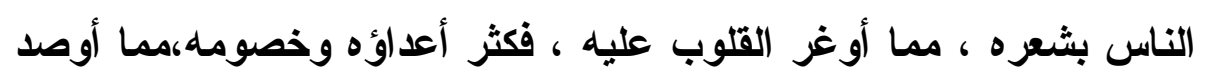

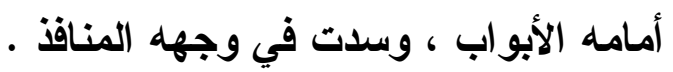

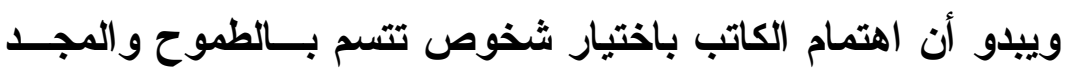

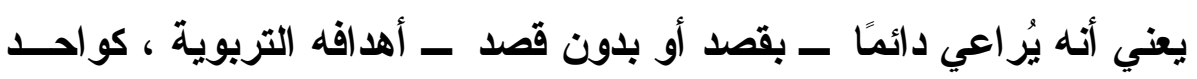

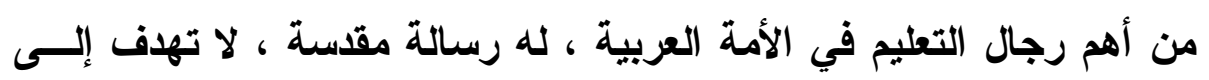
التعليم فقط ، بل تهاف إلى غرس القيم السامية ، ولفت الاتتباه إلى الأخلاق الأل النبيلة .

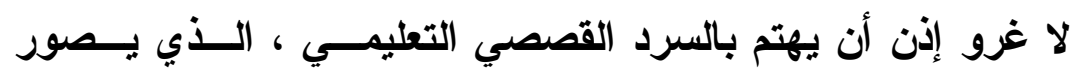

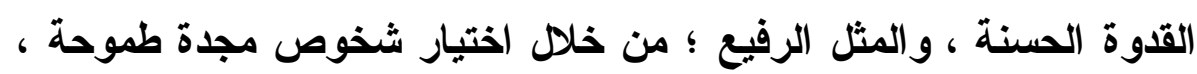
تستطيع أن تقدم النموذج المطلوب .

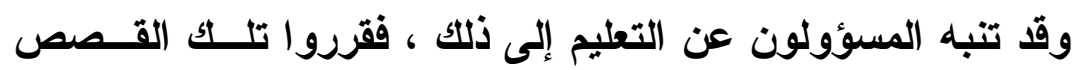
على تلاميذهم في عقود سابقة . وعلى هذه الثَّاكلة كان الجارم ينتقي شخوص فئلة قصصه التاريخية

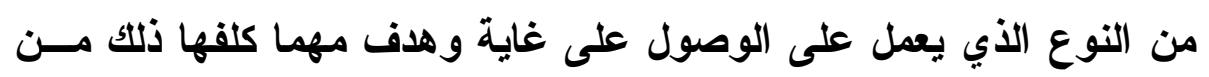

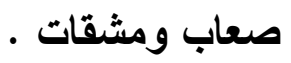


وقد رسمها رسمًا دقيقًا مُجمعًا ؛ بحيث أبرزها ماثلة للعيان ، بعـــ

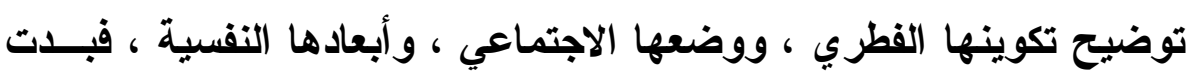

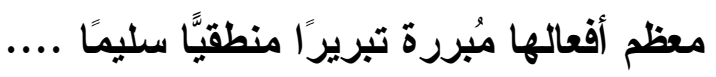

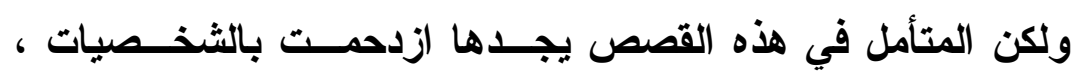

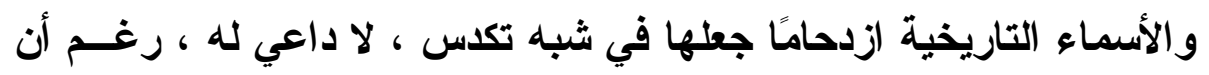

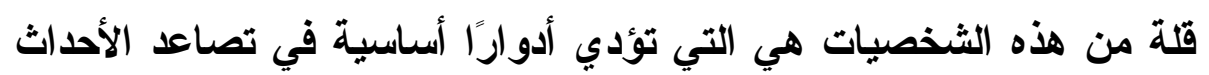

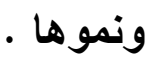

ويبدو أن مرد ذلك هو الاهتمام الثديد بحثد الوقائع التاريخية فــي

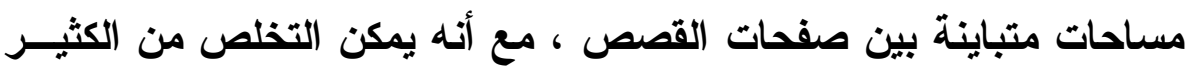

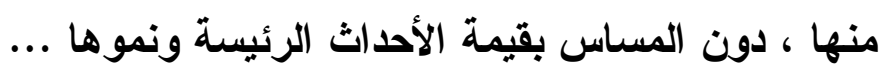

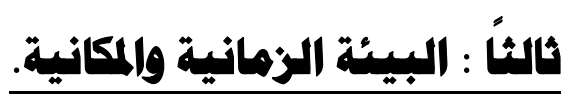

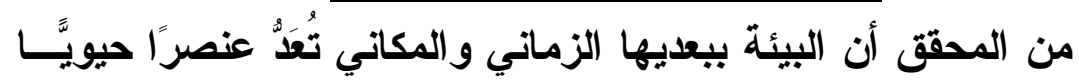

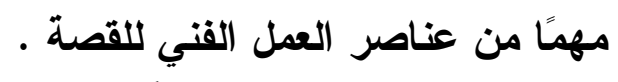

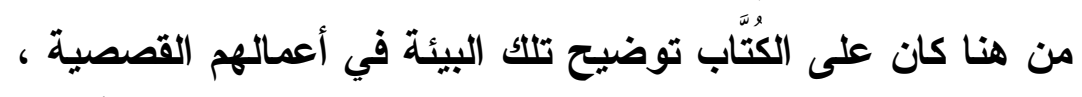

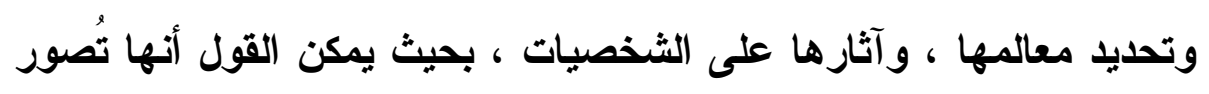

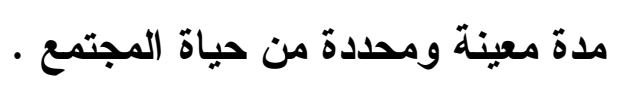

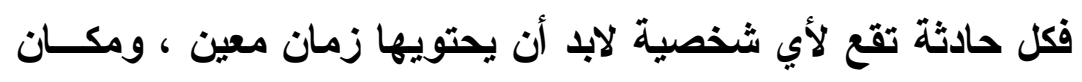

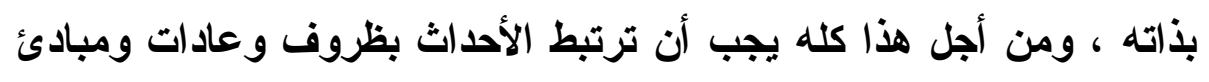

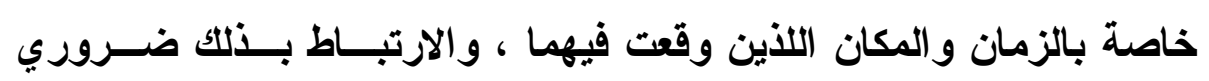
لحيوية القصة ، لأنه يمثل البطانة النفسية لهان(') .

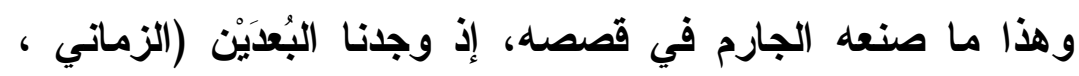

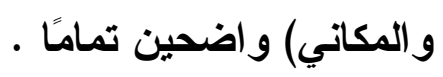

(') راجع:الأدب وفنونه.د / عز الدين إسماعيل.ص ؛ 19 ـ دار الفكر العربي بالقاهرة . ط - rivo 
حيث حددهما - على عمومهما - وجعلهما فـي بوتقــة واحـــة ،

فمزج بينهما في كثير من الأحداث الفرعية ، ثم جعل منهما عنصرًا حركيَّا

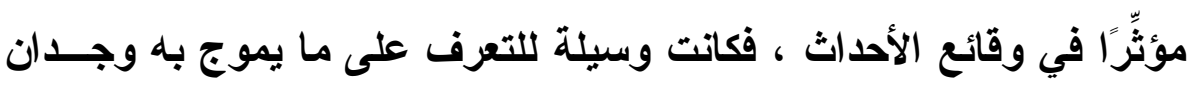

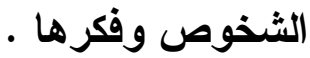

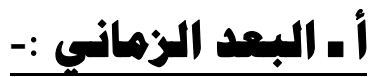

اتخذ الجارم البعد الزماني في أحداث قصصه من التــاريخ العربـي الإسلامي ، ابتداء من العهد الأُموي ، حتى نهاية العصر العثماني ، وبدايـــة

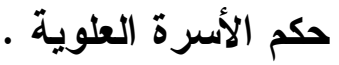
على أنه لم يعرض المرحلة التاريخية المرٔرة بأكملها ، إنما عرض الأل حقبًا بذاتها ، حددها منهجه الأي رسمه لنفسه عند صياغة تلكك القصص .

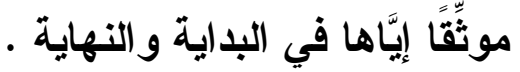
مثلما فعل في قصة (مرح الوليد) ، حيث كشف عن التــاريخ الــــي

$$
\text { وقعت فيه أوائل ، حيث يقول :- }
$$

(وفي أحد أيام شوال من سنة ثلاث وعشرين ومائة ، جلس ببعض أبهــاء

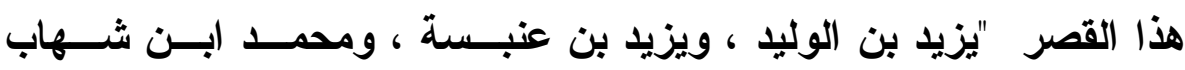

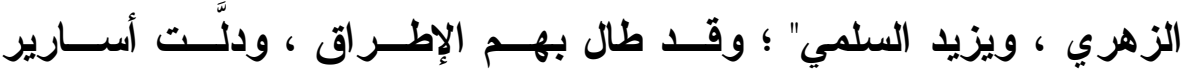
وجوههم ، على ما تنطوي عليه أنفسهم من أمرٍ عظيمٍٍ ، وهَمٍ دفين ...)(')

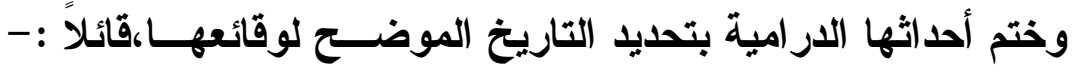

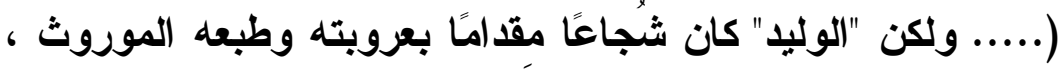
فلم يأبه لانصر اف أصحابه عنه ، واعتزم أن يلقى القوم بنفسه ـ ففي أحسـ أيام جُمَادى الأولى من سنة ست وعشرين ومائة ، ركب فرسه "الـسندى" ،

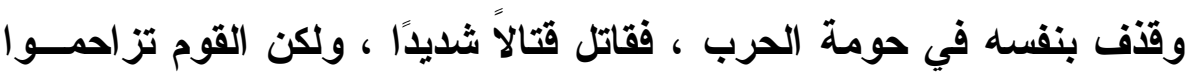

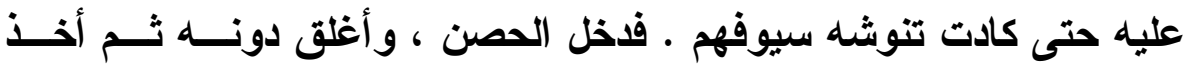


المصحف ، وجلس يُرتِّل آيات القرآن الكريم ، و انتحى "أبو رقية" ناحية من وني

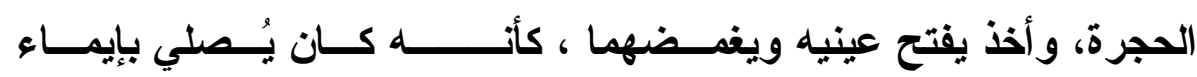

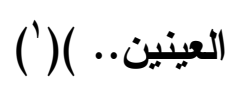

و أثناء سرد وقائع الأحداث التاريخية المهمة في هذه القـصة قــام

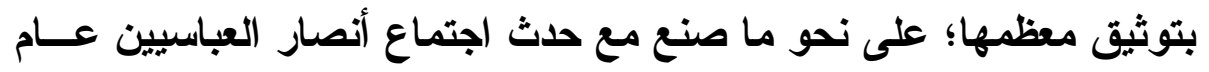
צ ب اهـ ، لتدبير بعض المؤامرات ضد الأمويين ـ فيقول :-

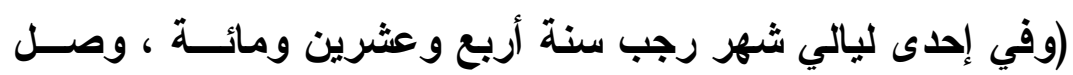

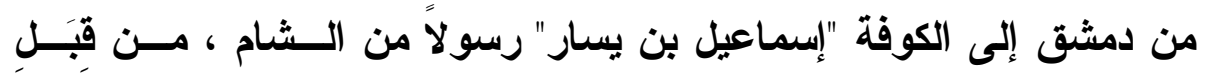

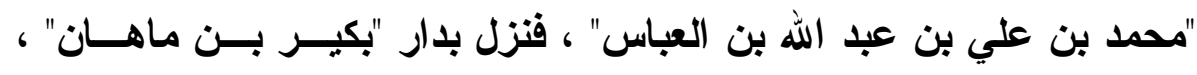

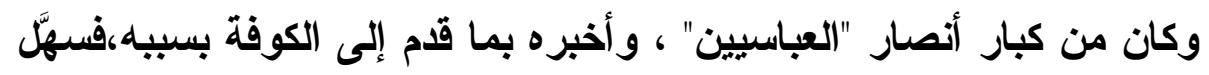

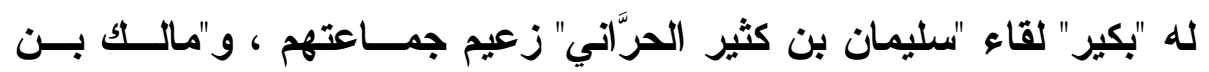

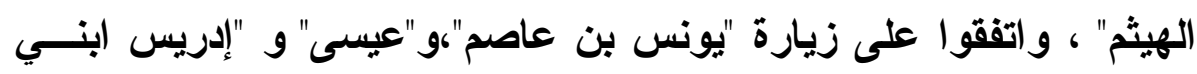

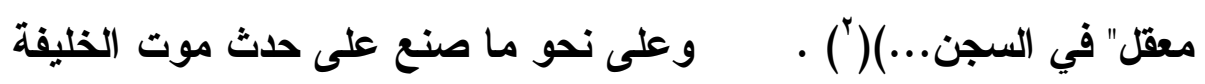

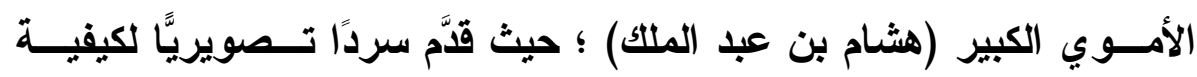

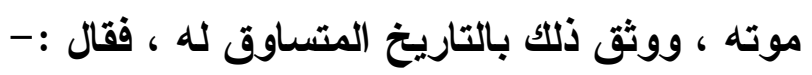

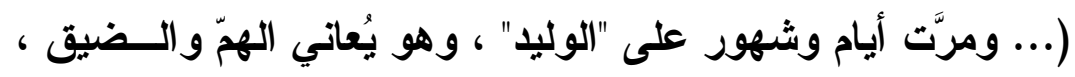

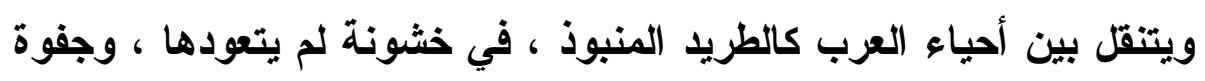

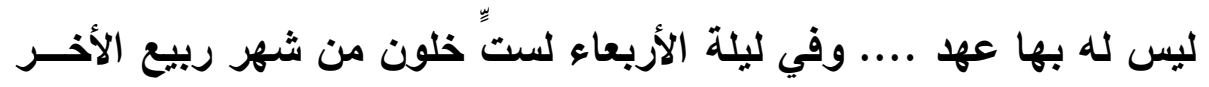

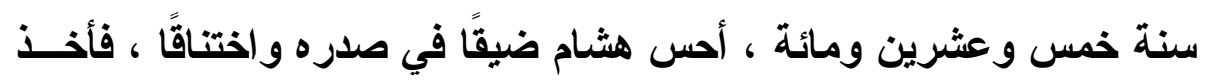

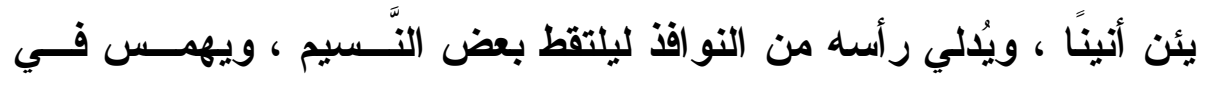

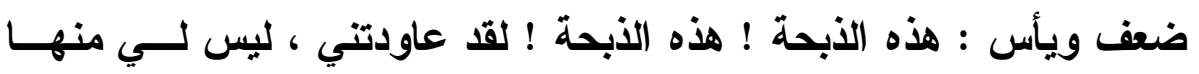


نجاة هذه المرة ـ مُروا "فيروز" يحضر دواء الذبحة ، فإني مـــا أرانسي إلا

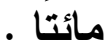

أسرع "فيروز" فأحضر الزجاجة ، ولم يكن بهـــا إلا مـــاء ملـــون ، فئس

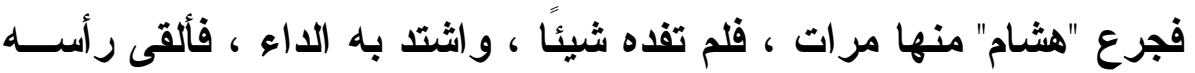

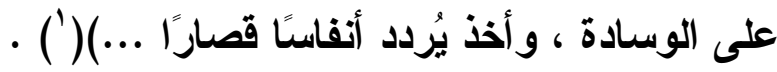

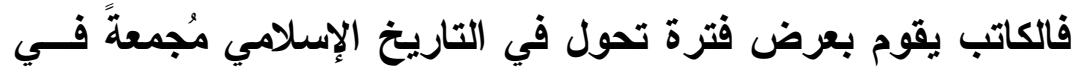
شخصية بارزة ، يُناظر تطورها تطور العياة الخاصة بالفرد ، وتطور الحياة

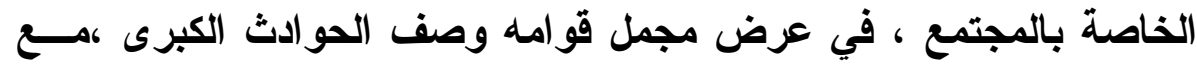

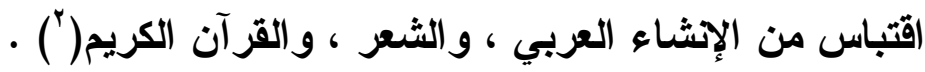

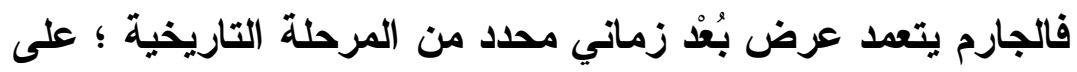

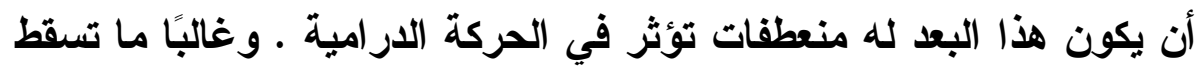
فيه دولة ، وتقوم على أطلالها أخرى . و هكذا كان الجارم يتخيَّر حقبة زمانية واقعية من التــاريخ العربـي العي الإسلامي ـ فهو في قصتي (مرح الوليد ، والفارس الملثم) ، صور البيئـة

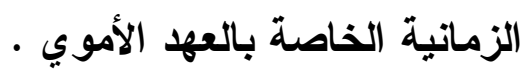
وفي قصص (سيدة القصور ، وفارس بنــي حمـــان ، والــشاعر الطموح ، وخاتمة المطاف) ، صور البيئة الزمانية الخاصة بعسصر الــدول والإمارات في العهد العباسي ، وهاعل وفي قصتي (ثاعر ملك ، وهاتف من الأـــلس) ، صـــور البيئسة

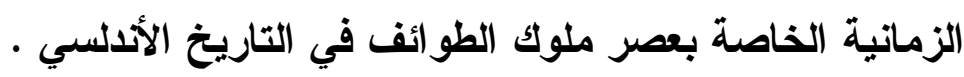

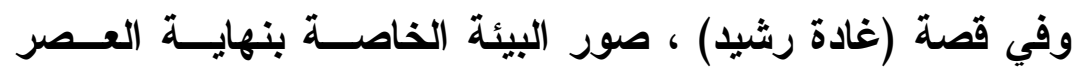
العثماني ، وبداية حكم الأسرة العلوية في مصر .

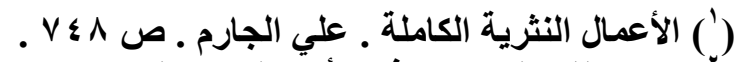

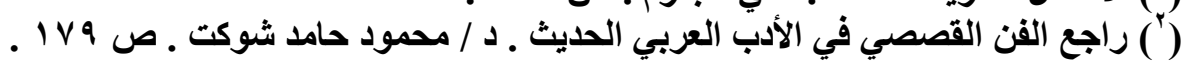


بيد أن استخدام البعد الزماني في الحبكة الدرامية ، له كيفية فنية ،

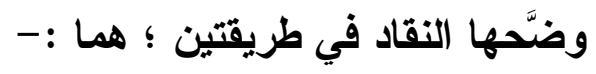

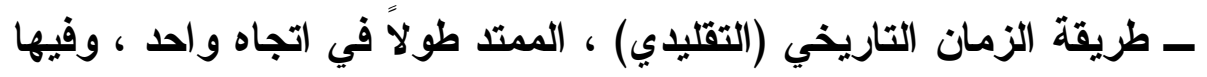

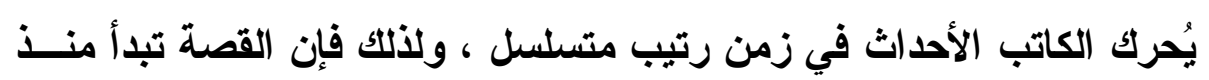

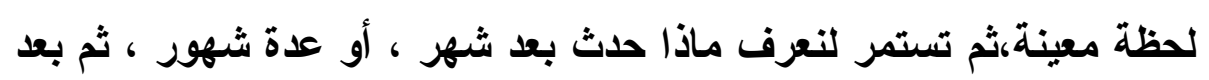

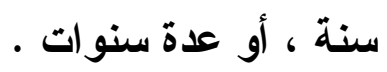

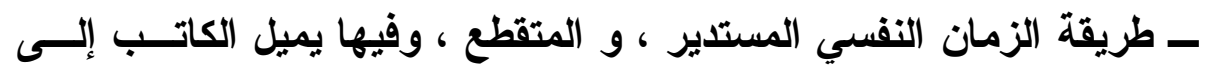

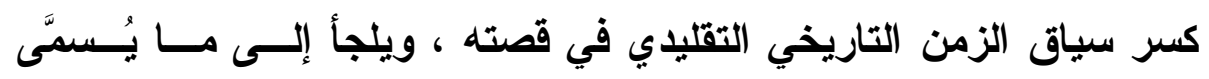

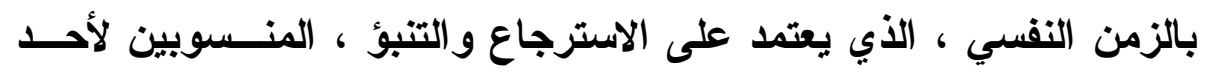

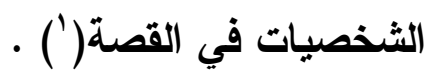
وبالتأمل في نتاج الجارم القصصي نجد أن الكاتب سلك الطـريقتين

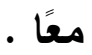

فرأيناه في الطريقة الأولى يتحرك بأحداثه متوائمًا مع حركة الزمن

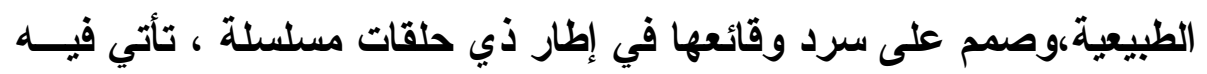
الأحداث متتابعة في نظام تصاعدي . فكلما مر الزمن مروره الطبيعي تكثفت لنـا الأحسـاث ، وتتابعــت المو اقف ، التي يأخذ بعضها برقاب بعض ، لعن مرون في تسلسل منطقي .

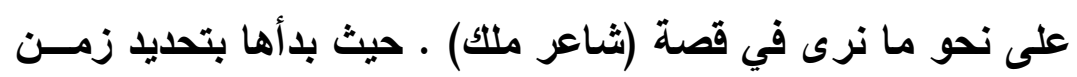

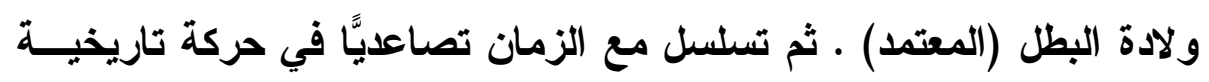

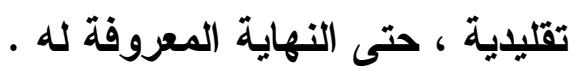

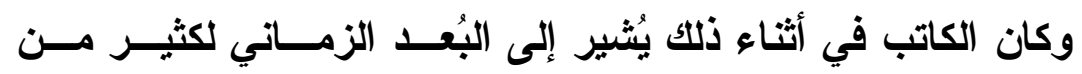

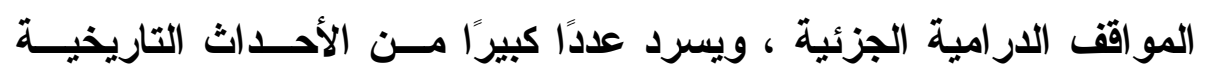

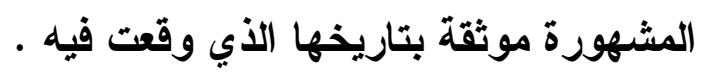
(') لمزيد من الإيضاح راجع : دراسات في نقد الرواية ـ د/ طه وادي ـ ص بr وما بعدها - rivq _ 
فها هو ذا يُشير إلى مولد البطل في بداية أحاث القصة قائلاُ:-

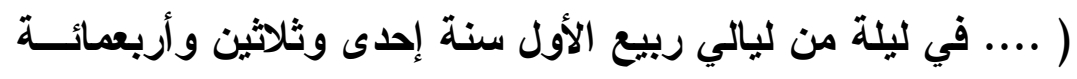

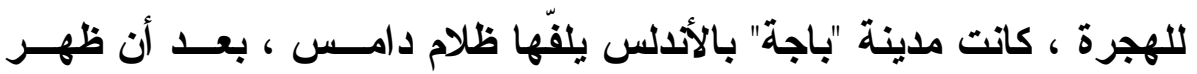

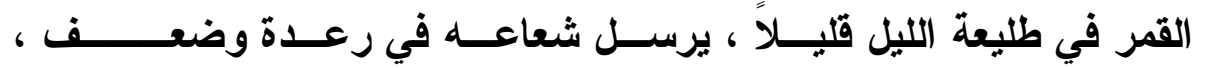

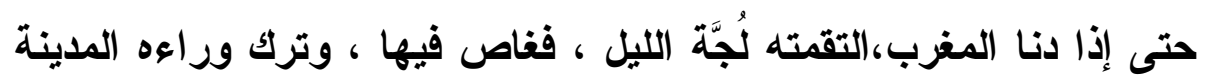
في تجهم ، وسكون وحداد ...)(') .

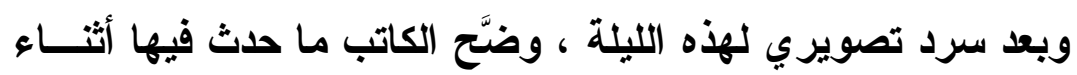

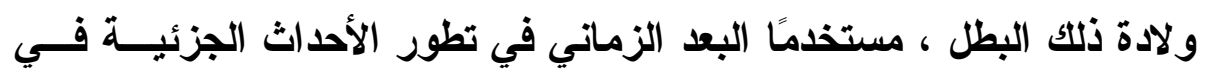

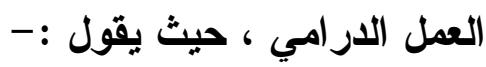

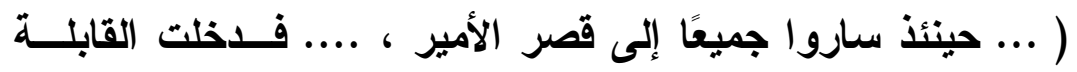

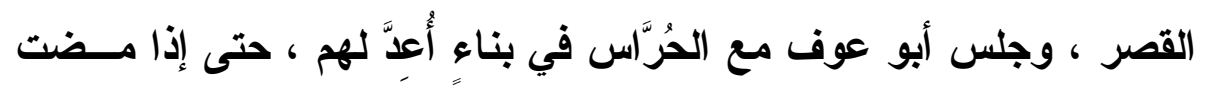

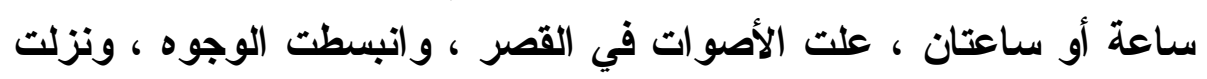

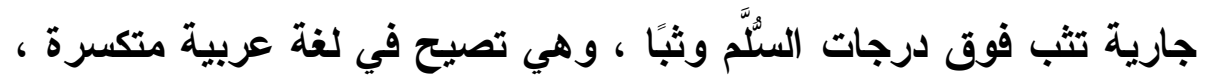

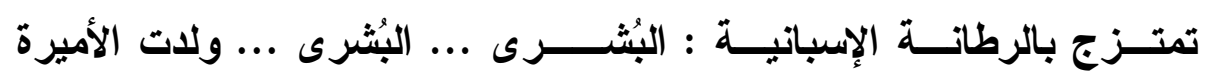

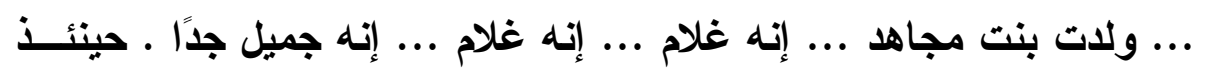

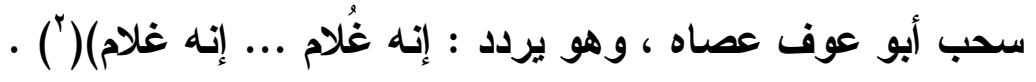

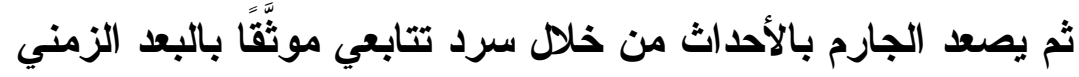
المؤثر في الحركة الدرامية ، فيقول : بالادئ

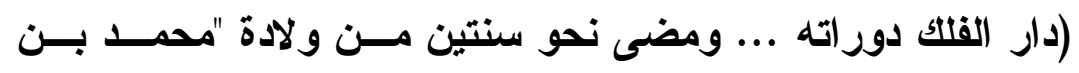

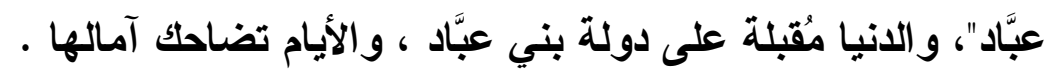

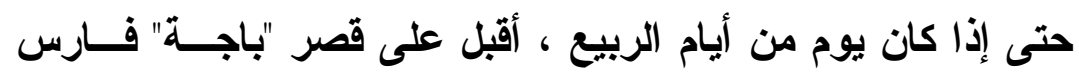

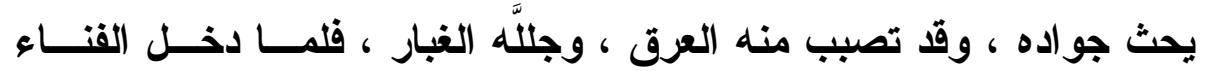


تو اثب إليه الحـــراس والجنود من كل مكان ، فعرفوا فيـهـ الحـرث بـن

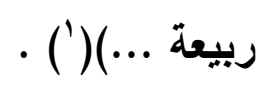

ويستمر صعود الأحداث في تسلسل زمنــي متو افـق مـــع تطــور

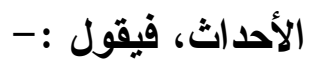

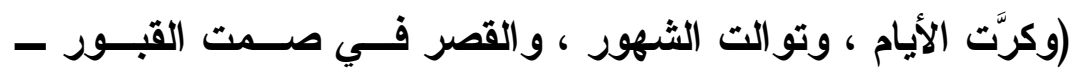

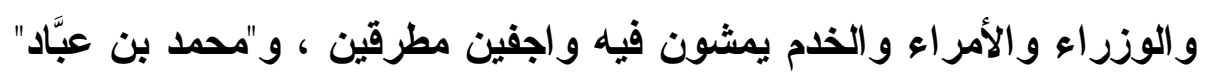

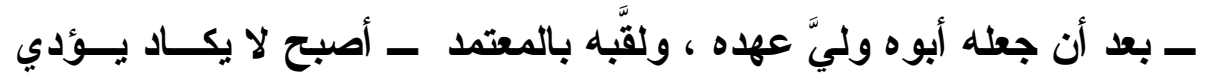

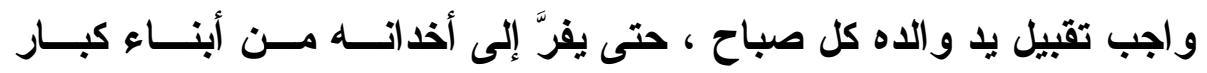

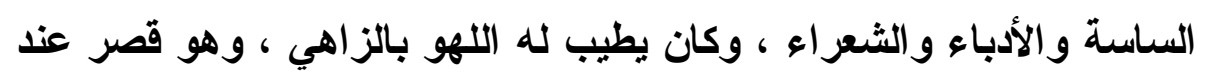
باب العطارين بأثبيلية ....)(") .

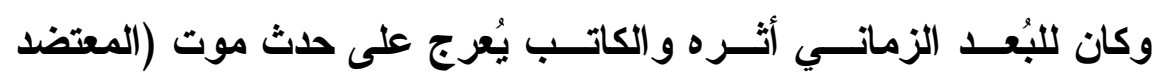

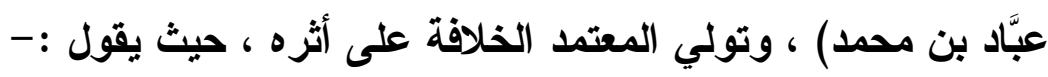

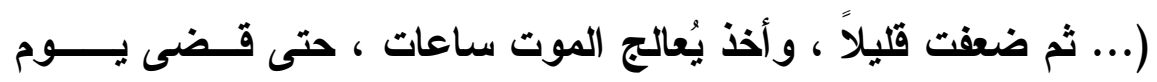

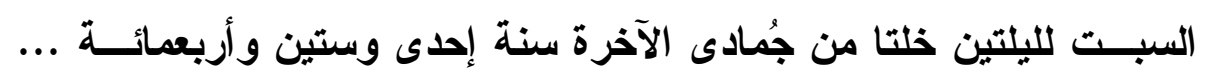

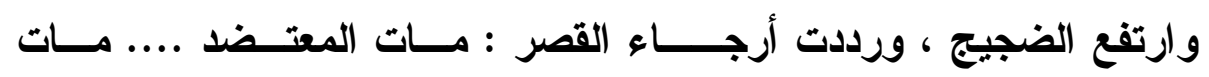

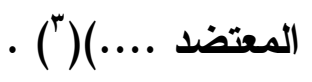

ويسترسل الكاتب في صعود الحدث حتى جاء التوقيـــــ الدرامــــي

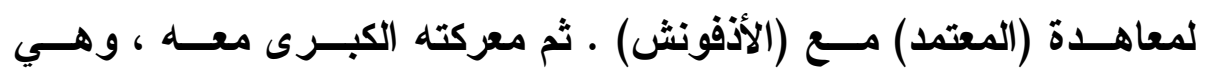

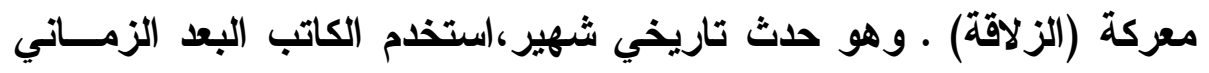

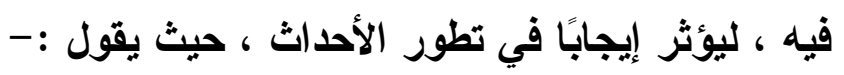

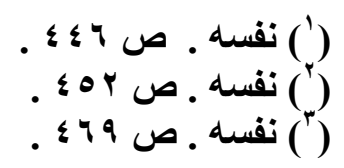


(... وفي صبيحة الجمعة ، العاثر من رجب سنة إحسـى وثمــنين

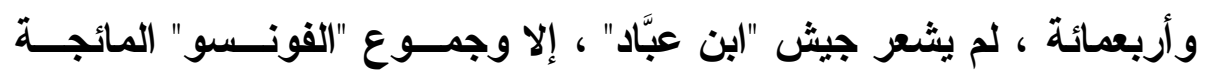

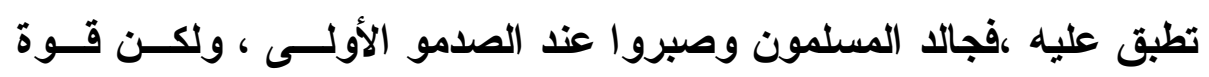

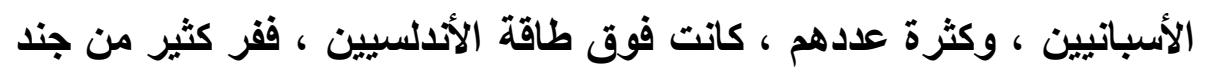

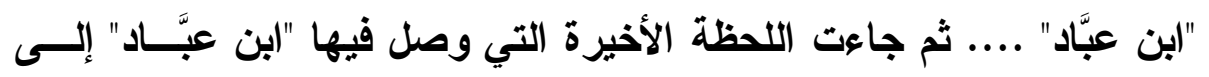

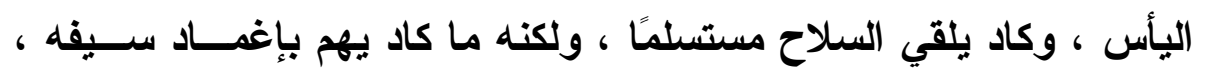

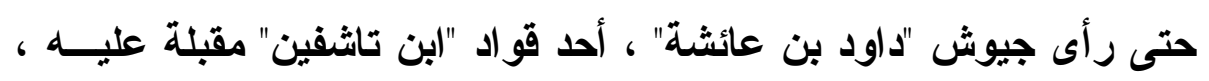

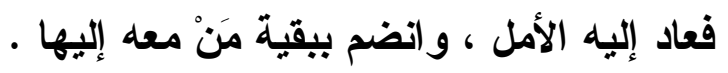

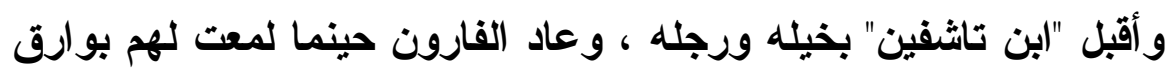

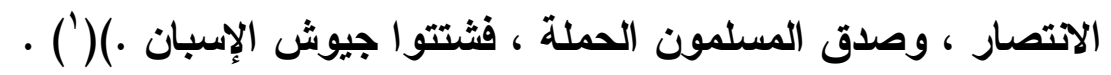

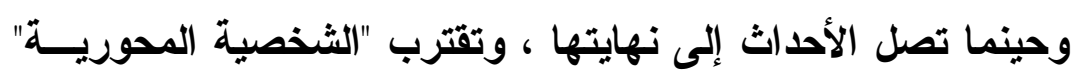

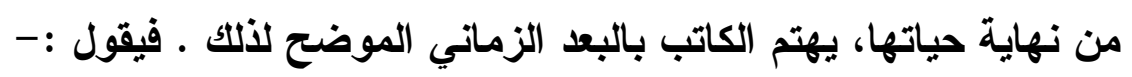

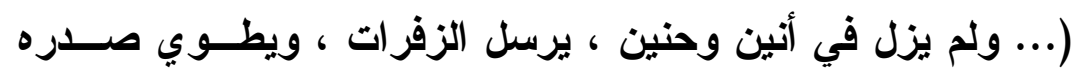

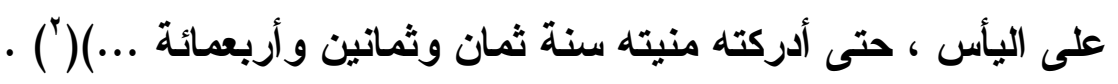

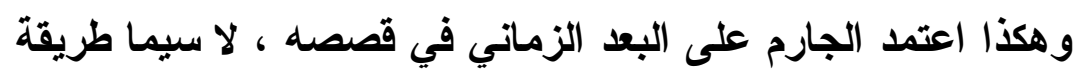

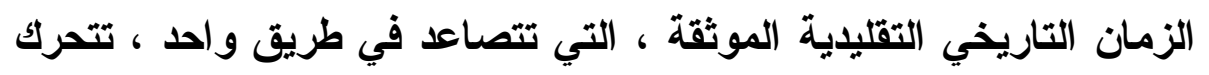

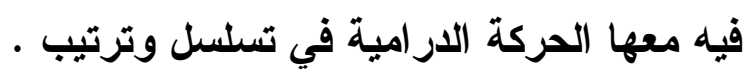

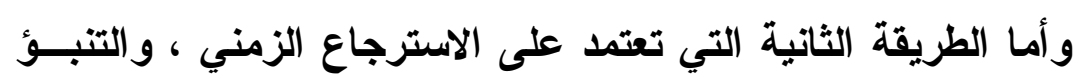

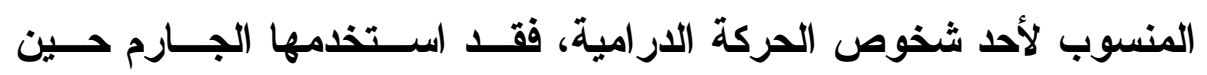

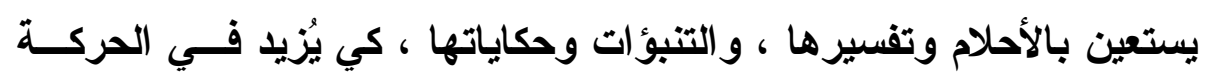

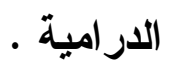


على نحو ما نرى في الاستعانة بالأحلام وتفسيرها في قصة (ثاعر

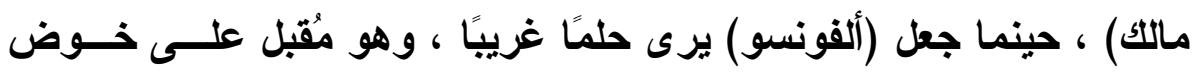

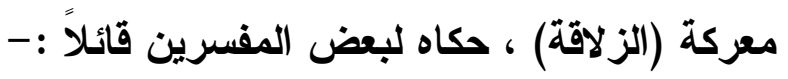

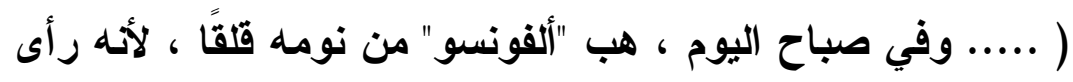

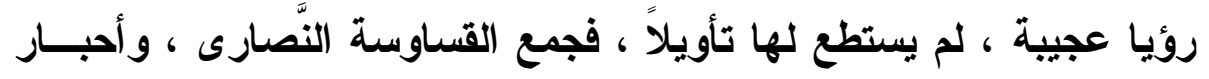

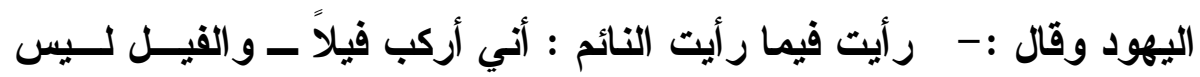

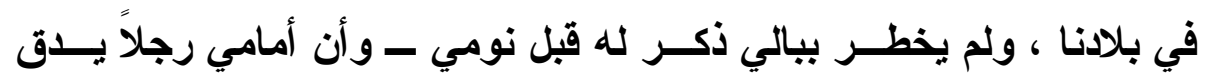

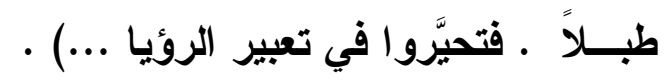

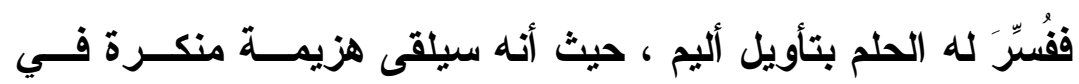

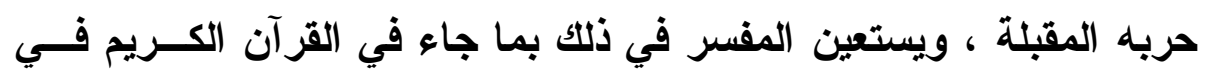
قصة أصحاب الفيل وغيرها ، قائلاً :- فئل

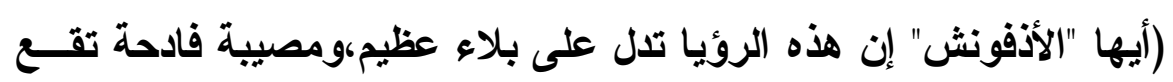

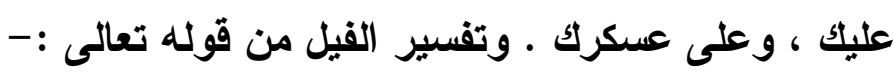

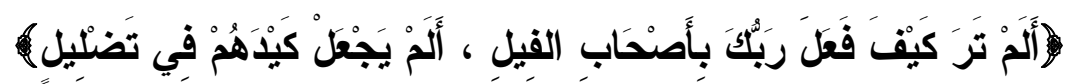

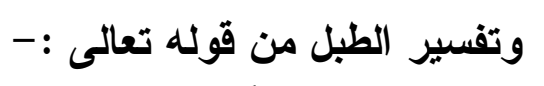

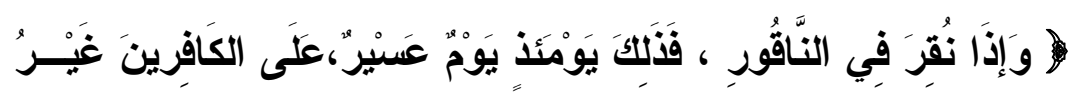

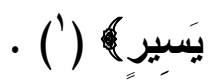

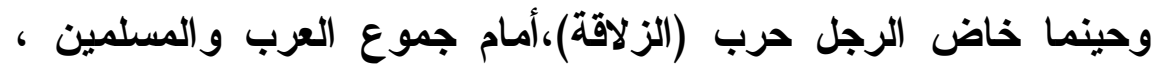

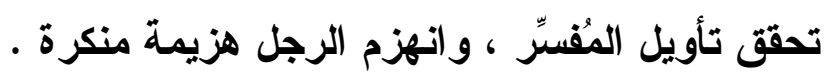

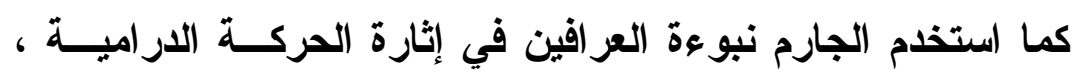

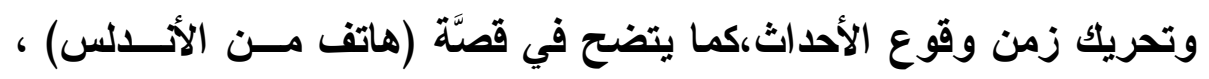

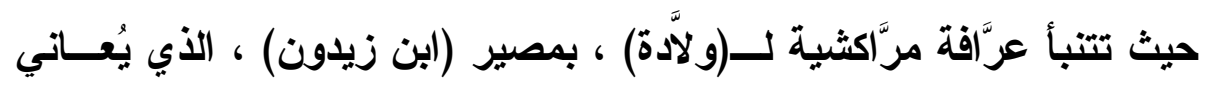




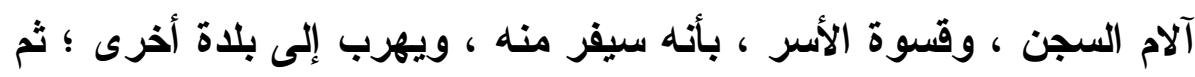

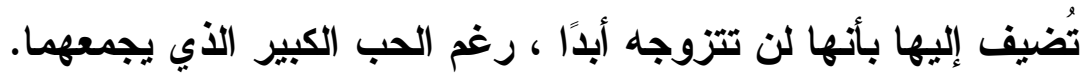

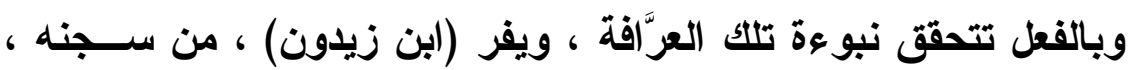

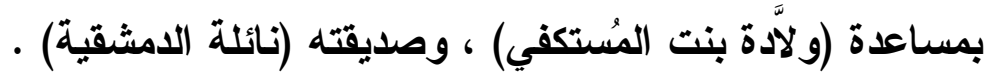

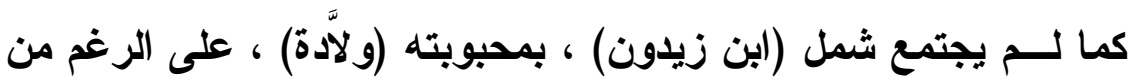

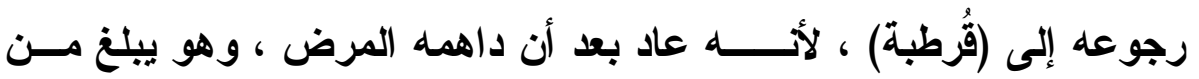

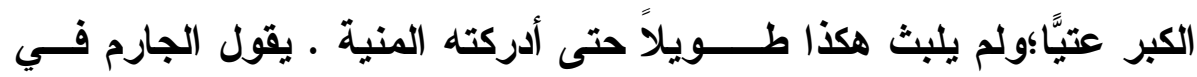
ذן :

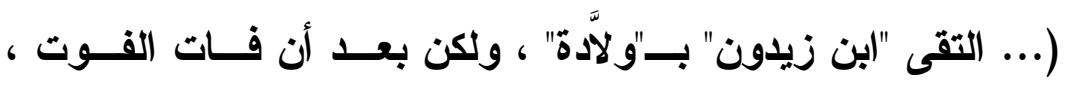

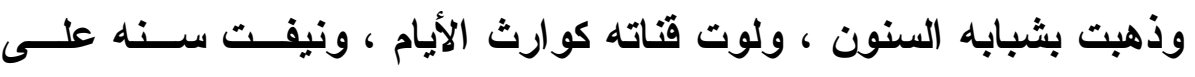

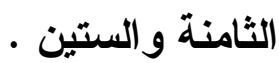

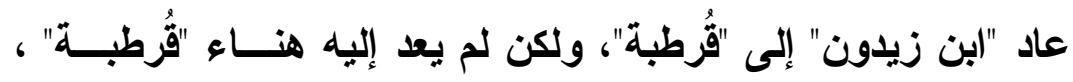

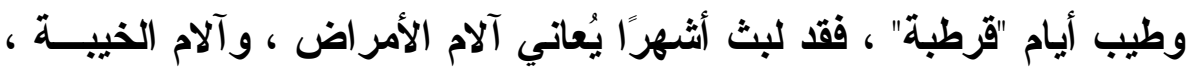

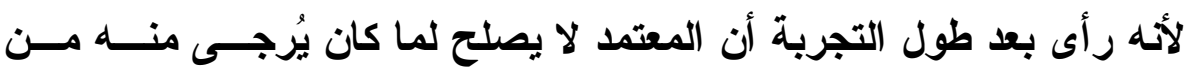

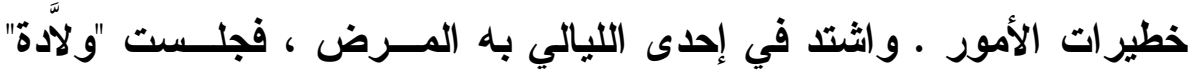

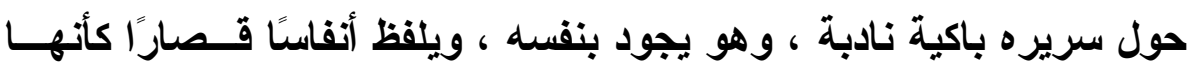
خفقات السراج آخر الليل ...)(') .

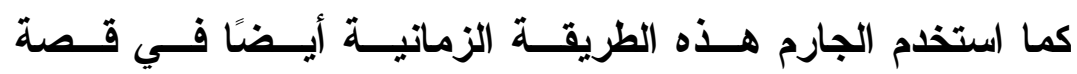

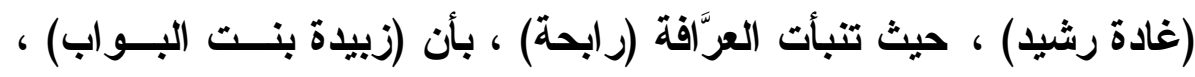

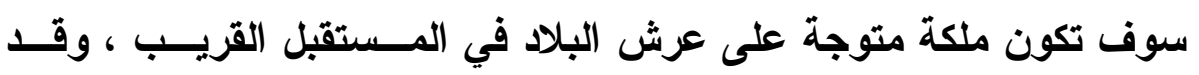

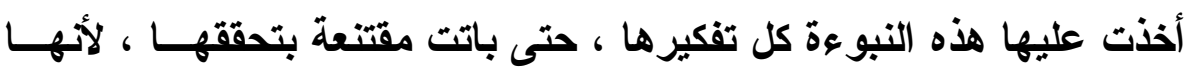

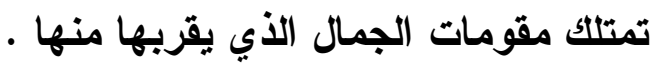




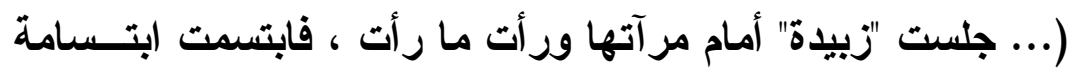

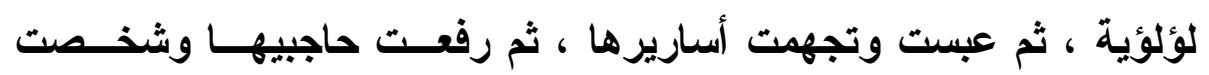

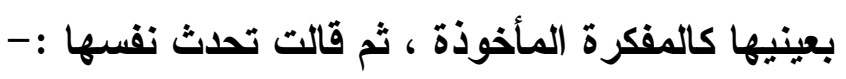

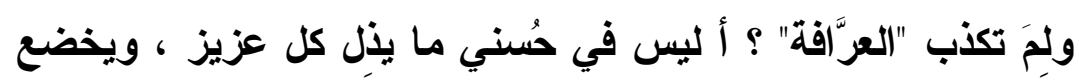

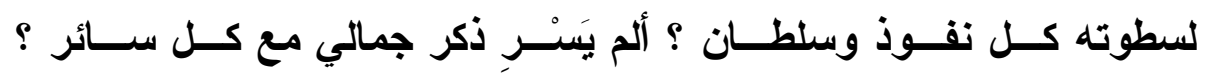
ويُطْرِ كل ريح ؟......

لا . لا . لن تكذب رابحة ، وهي لم تتكهن بثيء مستحيل ، أو بعيد

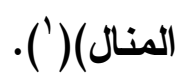

لم تستمر (زبيدة) طويلاً على هذه الحال،ققد تحققت نبوعة (رابحة)

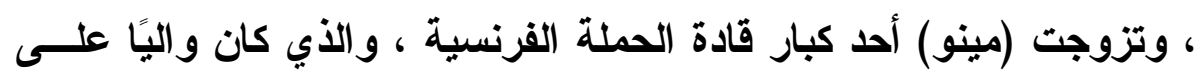

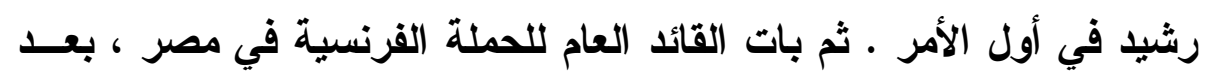

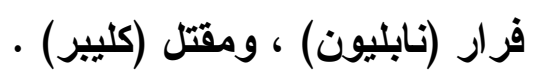

وقد تلخل الجارم في العدث الدرامي بتعليق يصور زفاف (زبيــدة)

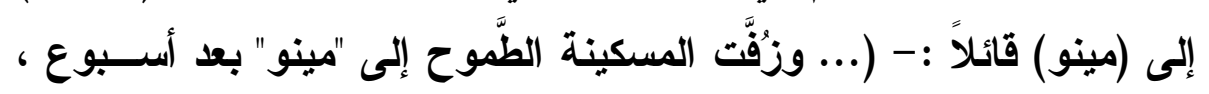

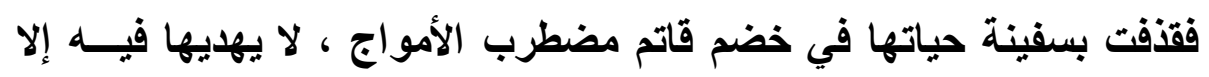

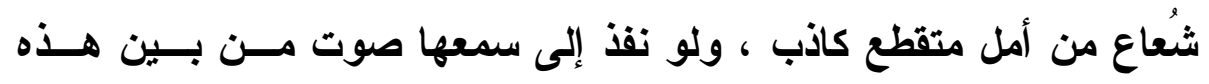

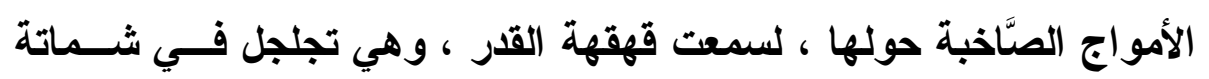

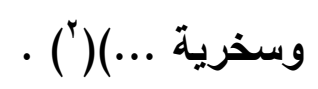

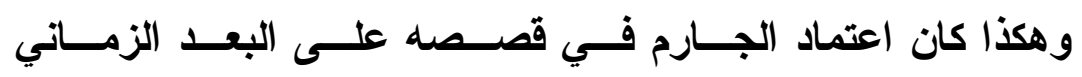
بطريقتيه:طريقة الزمان التاريخي التقليدي الممتد ، الــــي يُطــابق النظــام

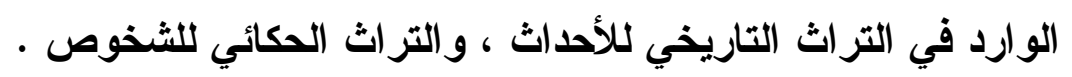


وطريقة الزمان النفسي المستدير ، التي تُسرِع الحركـــة الاراميــة إلى الأمام ، وتكثف تضاعيف الثخوص المعنوية و النفسية .

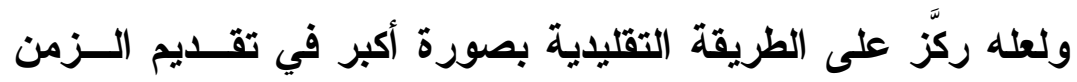

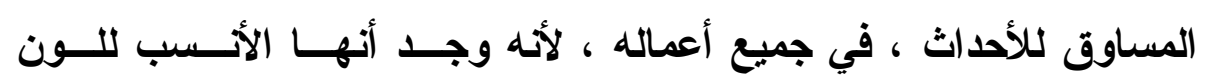

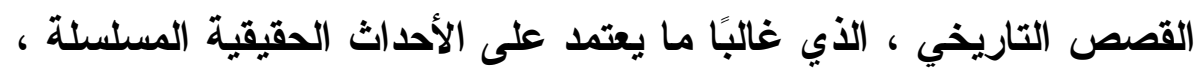

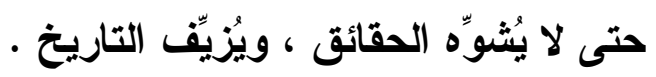

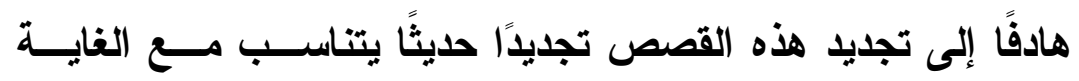

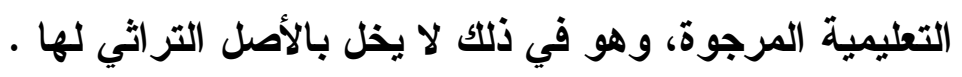

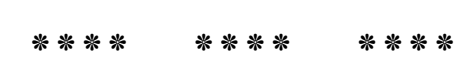

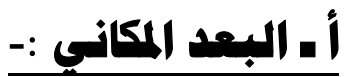

يتضح مما تقام من تحليل فني في قصص الجارم ، أنهــا مستستمدة

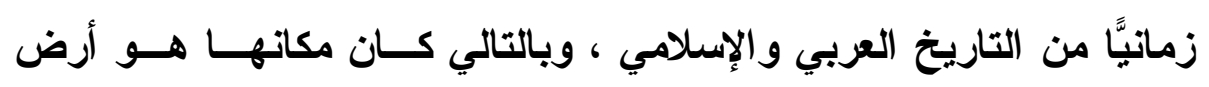

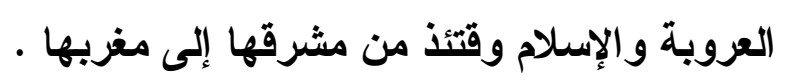

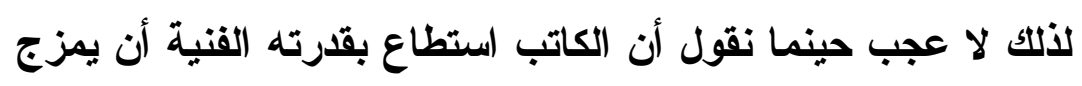

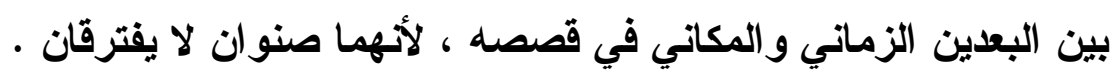

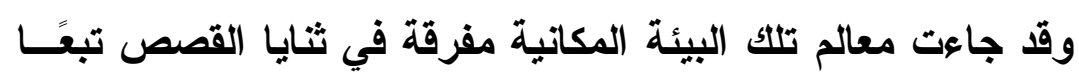

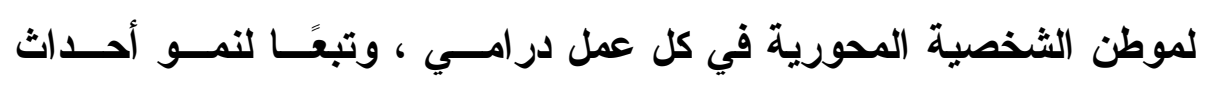

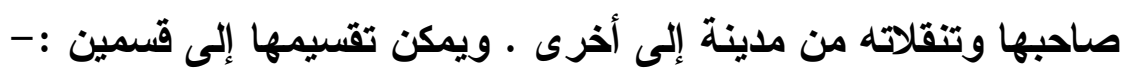

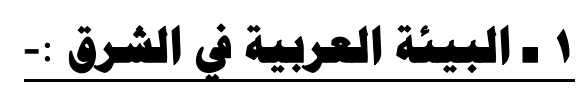

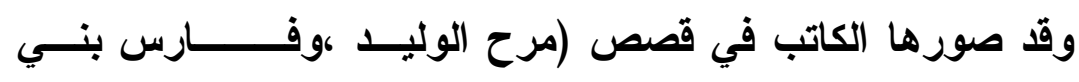

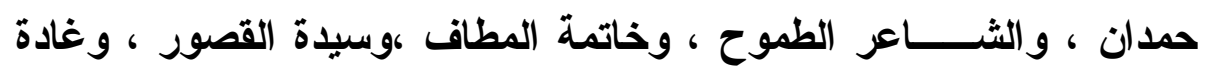

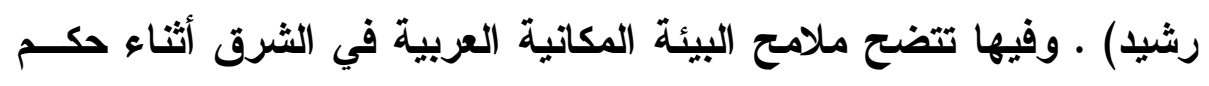

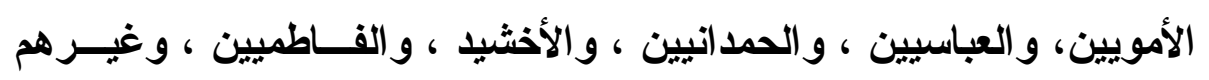




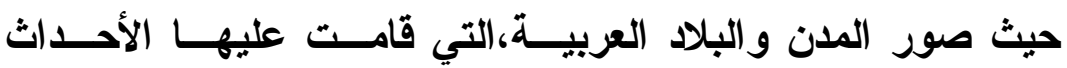

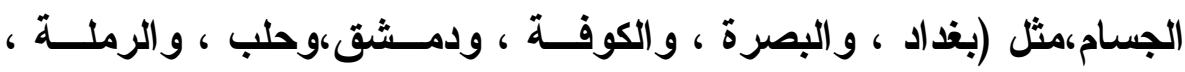

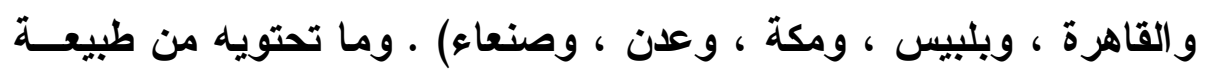

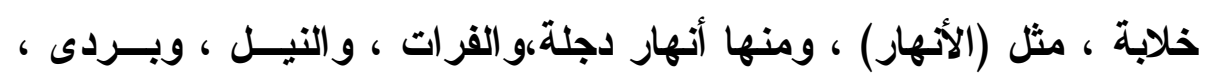

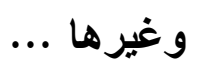

ومثل الأودية و الجبال و القصور والبساتين .

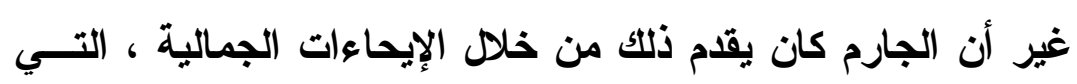

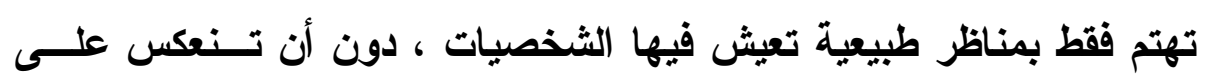

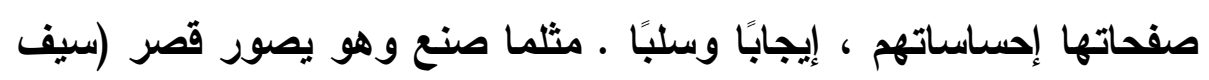

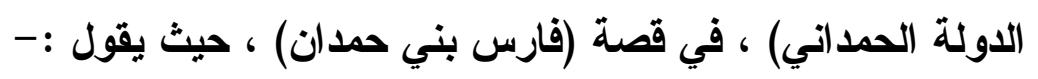

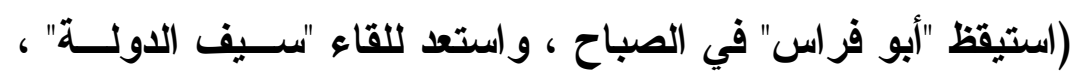

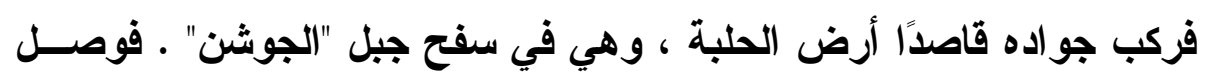

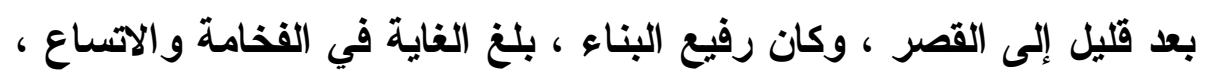

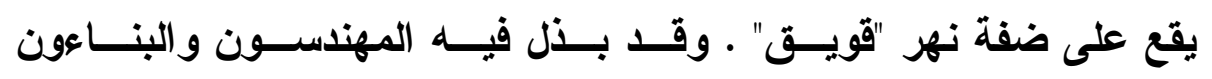

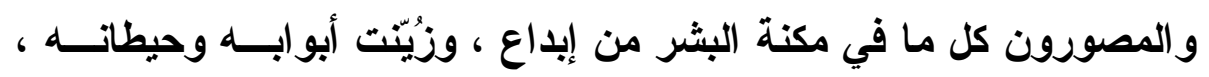

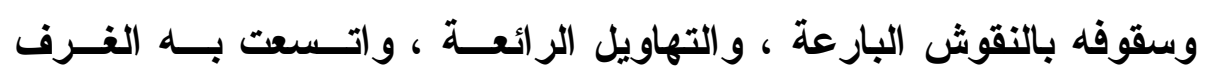

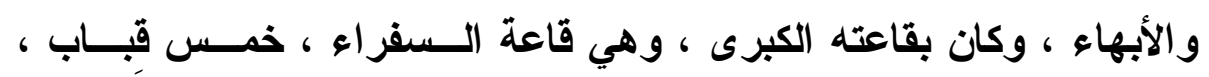

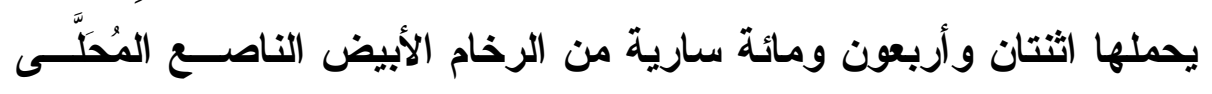

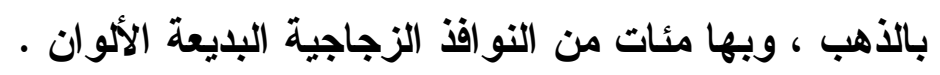

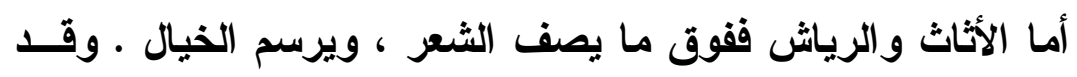

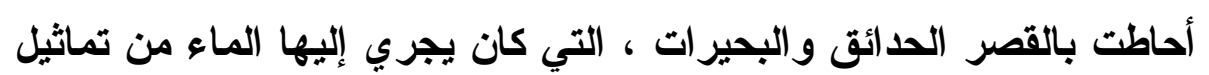

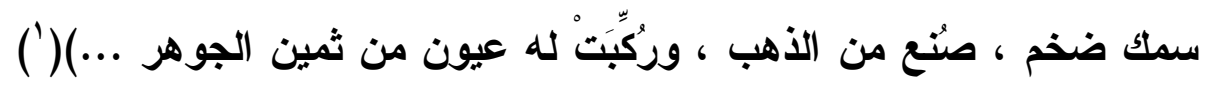

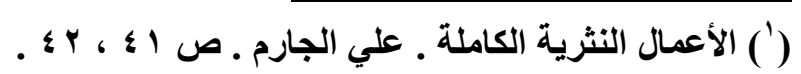


فالجارم قدم في السرد التصويري السابق عرض جمسالي إيحسائي

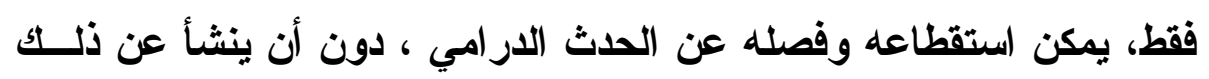

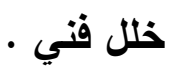

\section{r ـ البيئة العربية في الغرب :-}

وقد صورها الكاتب في قصص (ثماعر ملك ، وهاتف من الأندلس ،

و والفارس الملثم) .

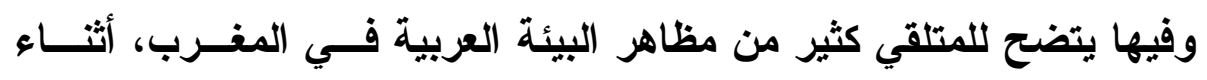

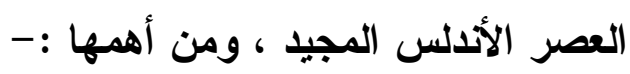

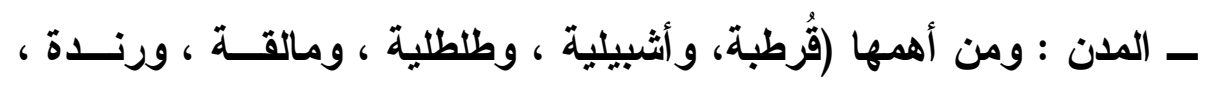

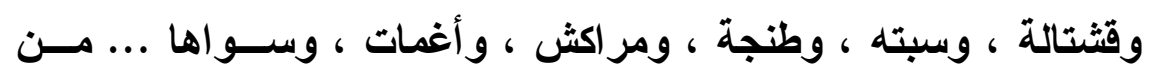

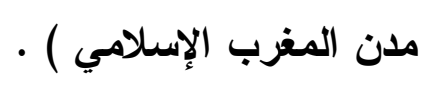

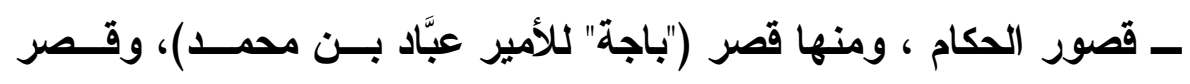

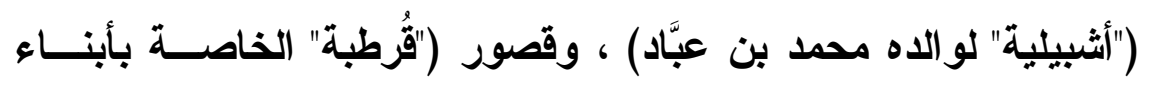

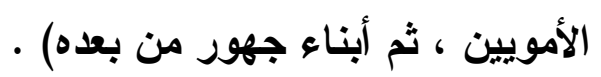
- ودور الوزراء و الكتاب و الثعر اء مثل (الدور الخاصة بـألوزراء)، ودار

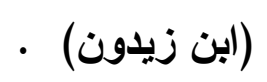

- ومساجد العبادة القائمة في كل مدينة لأداء الصلوات ، و إلقاء الاروس .

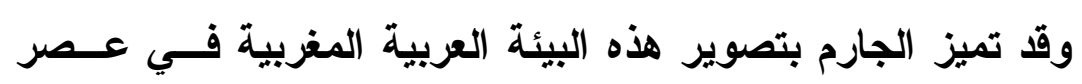

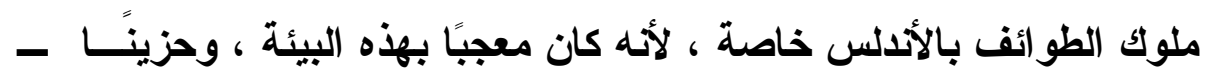

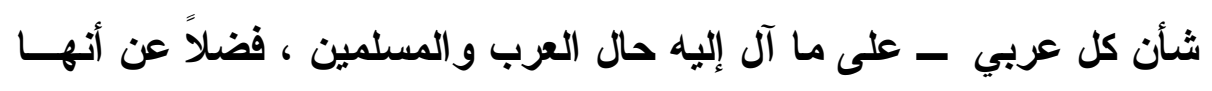

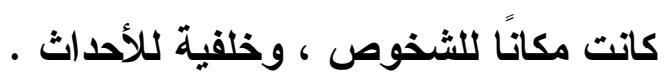

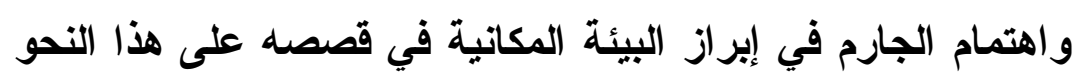

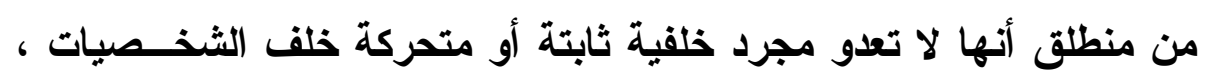

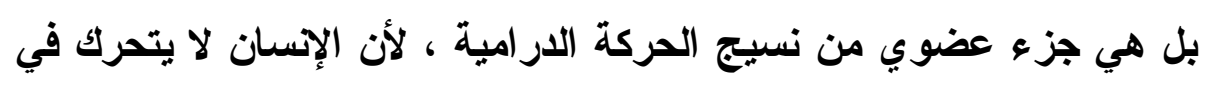
$-r \mid \Lambda \Lambda$ - 
فراغ ، ولا يمكن عزله عن العلاقات المتثابكة ، و المعقَّة ، و التي تربطـهـ

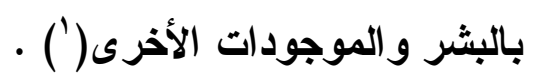
لذلك عُني كُتَّب القصة ـ ـ عامة ـ ـ بالبيئة المكانية ، وحاولوا إبراز

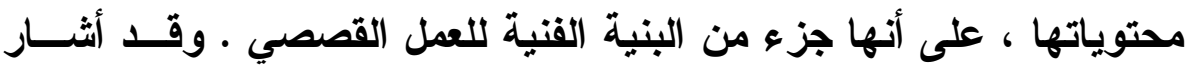

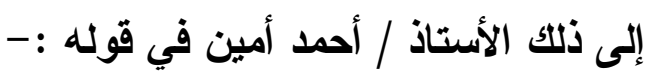

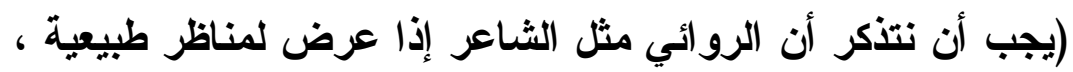

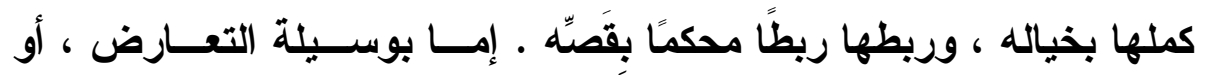
بوسيلة التعاطف . باله ورنطان

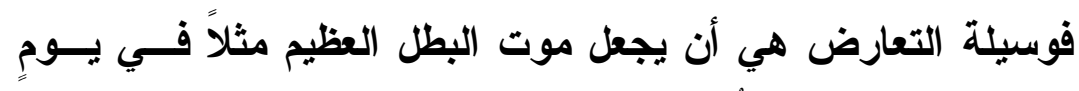

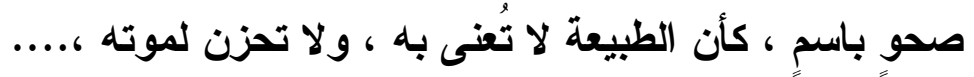

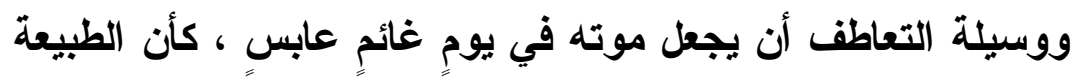

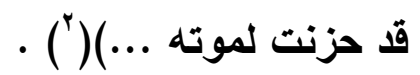
بيد أن أهمية البيئة المكانية تزداد قيمتها ، إذا كان الكاتسب يقــدم القصة في شكلها التاريخي الواقعي ، لأن من أهــــ أهــاف هـــا الاتجــاه

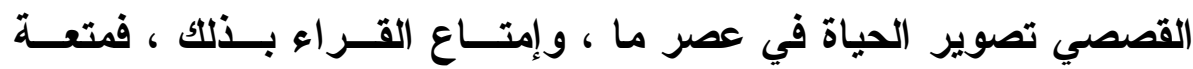

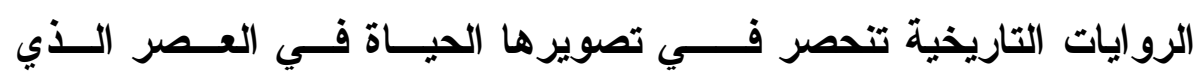

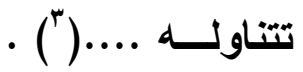
لا غرو إذن أن يهتم الجارم بتصوير البيئة المكانية في قصصه،في

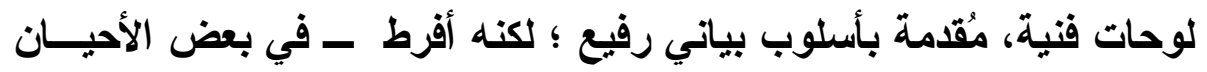

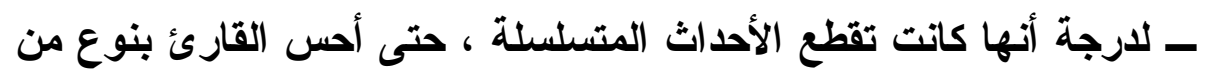

(') راجع : التفسير العلمي للأب ـ ـ / نبيل راغب. ص هب ا ـ بتصرف.الشركة المصرية

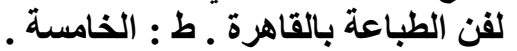

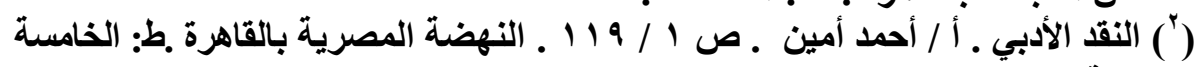

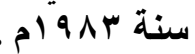

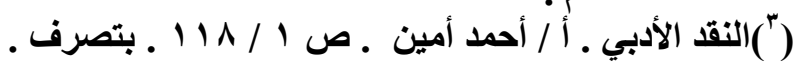
- rا人 _ 
الملل و الفتور ، لأنها ــ غالبًا ــ ما تكون خارجة عن الأحداث الاراميـة ،

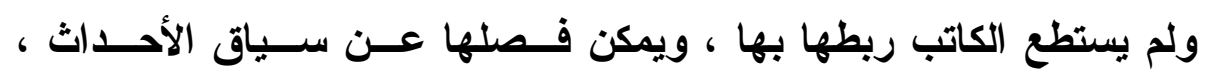

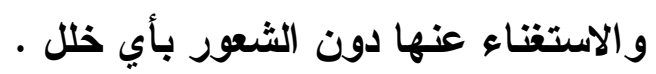

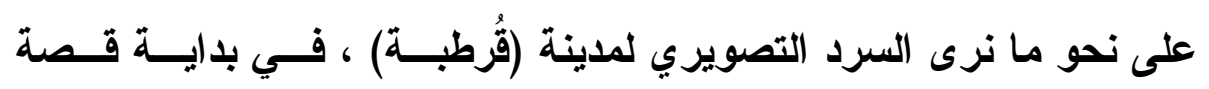

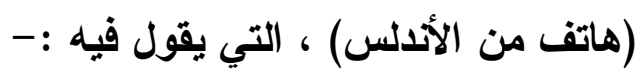

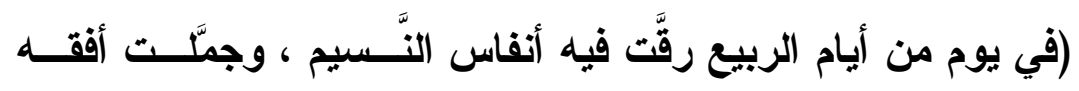

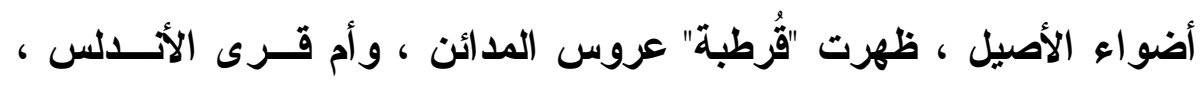

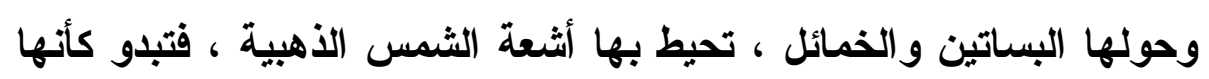

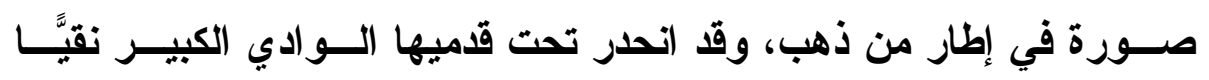

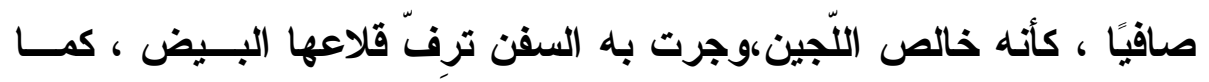

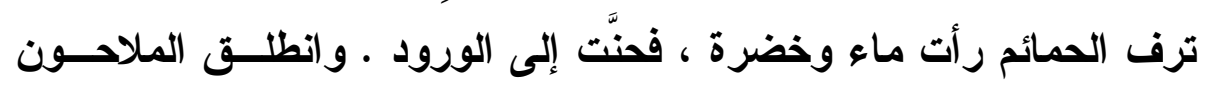

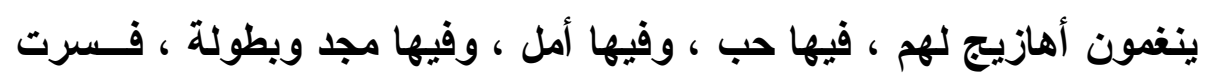

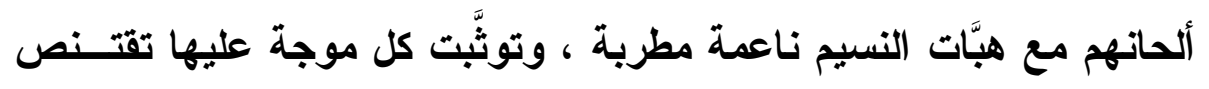

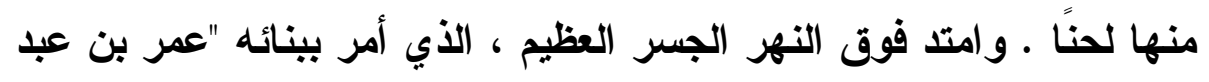

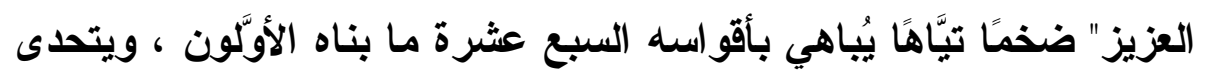

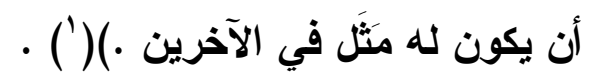
وكان على الكاتب بعد الاتتهاء من هذا السرد التصويري ، الن أن يربط

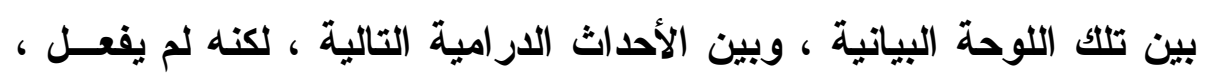

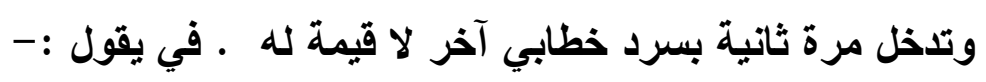

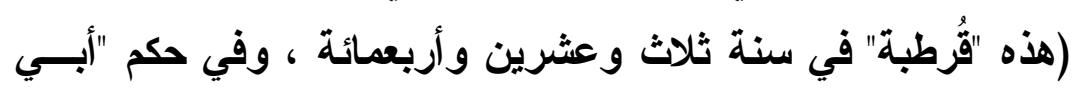

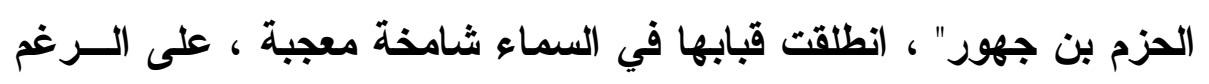
مما لاقته من الويلات و الفتن و الحروب وضروب الطها في التخريب و التدمير .

$$
\begin{aligned}
& \text { (') الأعمال النثرية الكاملة . علي الجارم ـ ص V. . . . . . } \\
& \text { - r الجارم . }
\end{aligned}
$$


هذه "قُرطبة" التي كاتت أيام "الناصر لاين الله" بهجة الدنيا ، وقبــــة

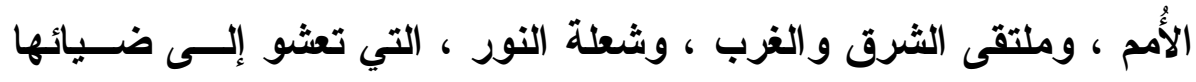

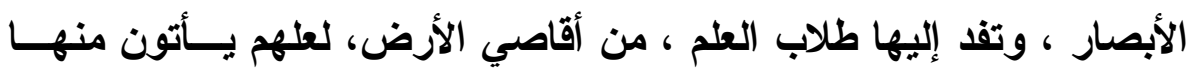

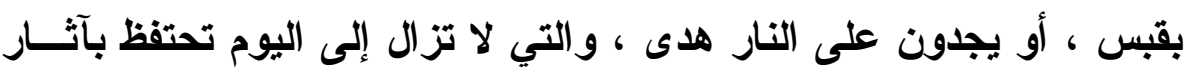

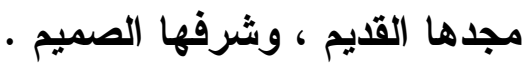

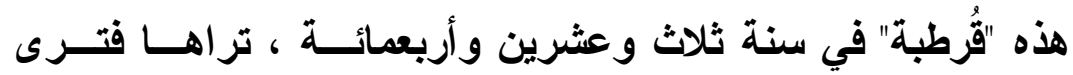
صفحة عجزت الخطوب عن محو سطورها ، ودوحة لم تعبث الأعاصـير إلا فئه

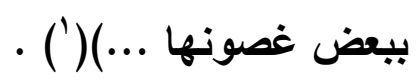

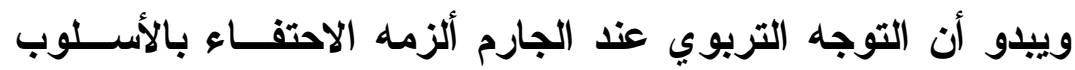
البياني ، وتقليم نماذج شعرية كثيرة في ثثايا قصصه ، للإفــادة التعليميـة الإنة

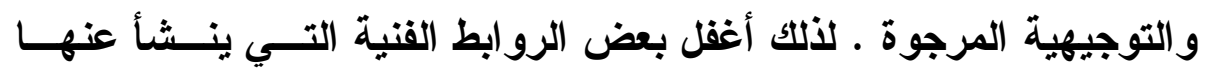

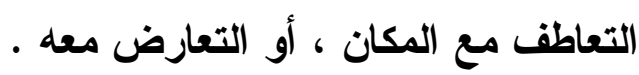
**** $* * * * * * * *$

\section{رابعاً : لغته الاسلوبية.}

من المقرر أن الأسلوب عنصر مهم في جميع الفنون ، وله طبيعـة

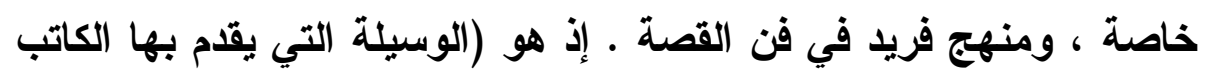
قصته ، و إذا كانت القصة تمتاز بالمرونة في مجال البناء القنـي ، فإنهـا

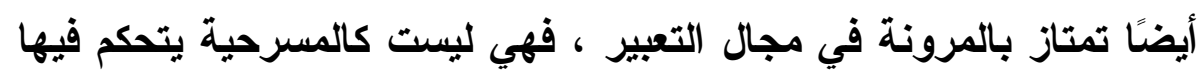

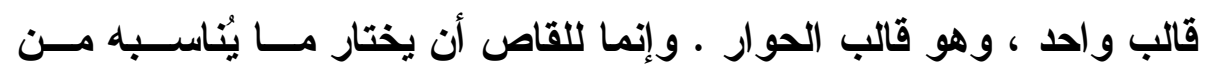

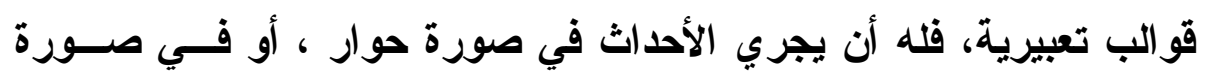

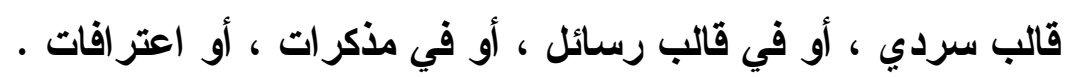

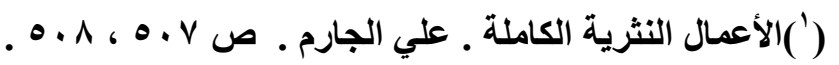

$$
\begin{aligned}
& \text { - r|q1 _ }
\end{aligned}
$$




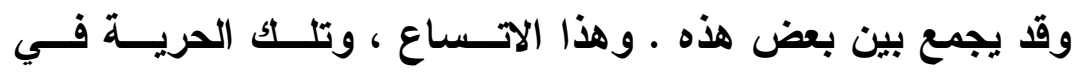

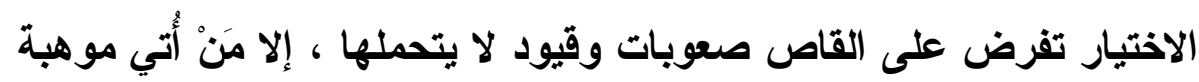

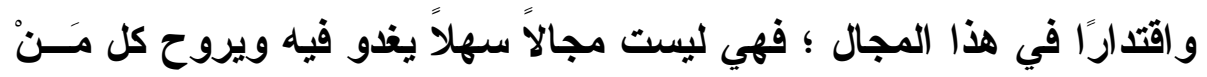

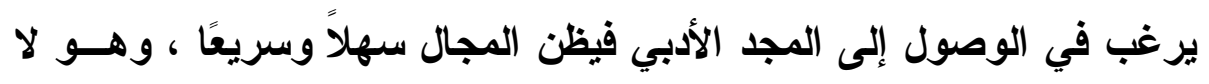

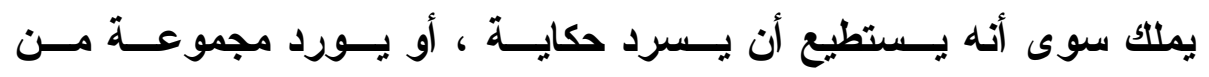

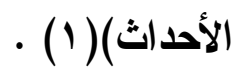

لا غرو إذن أن يكون الأسلوب هو الوعاء الأي يحوي بداخله كــل

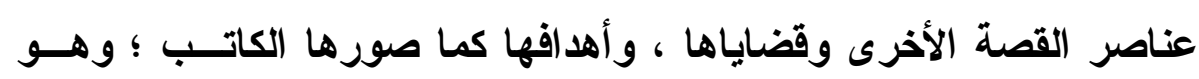

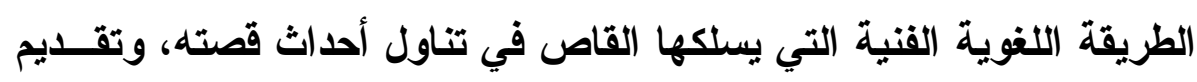
شخصياتها ، وبيان مو اقفها ، ووصف زمانها ومكانها ل...

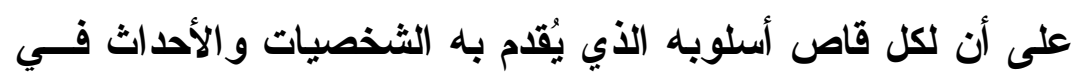

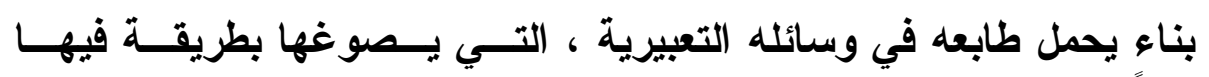

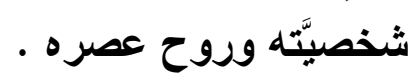
و القصة من الأنواع الأدبية التي صار لها سيطرة وذيوع فــي هــــا

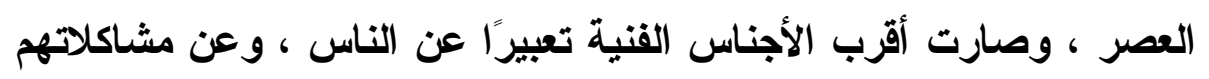

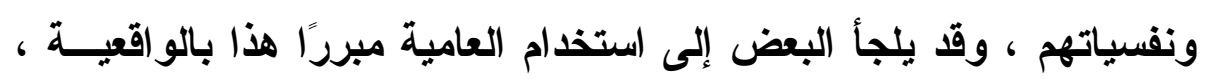

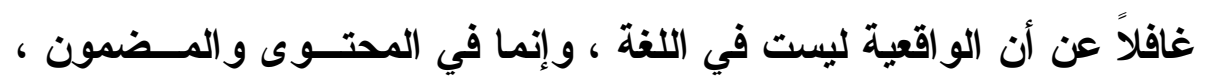

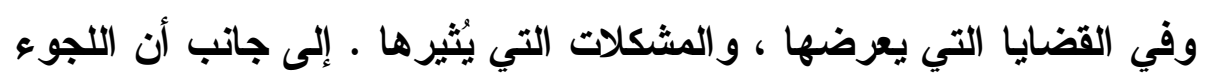

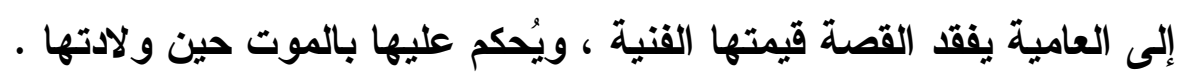

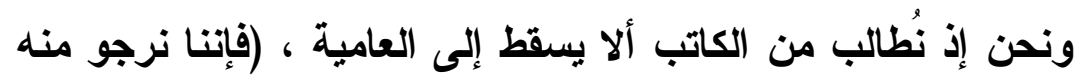

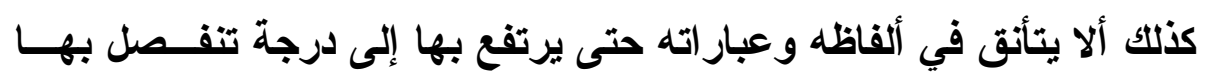
( ) لمزيد من التفاصيل راجع : القصة في الأب العربي ـ د/ متولي محمد البساطي ـ ص

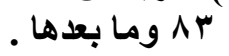


اللغة عن الأحاث ، وتصبح عذد الكاتب غاية في ذاتها ، ولا نراها معبـرة

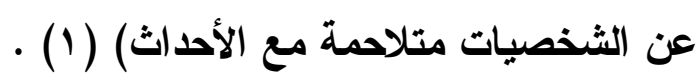
إذن فالفصحى المطلوبة في الأسلوب هي أن تكون مفرداته (فيحة)

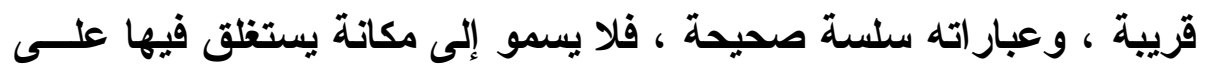

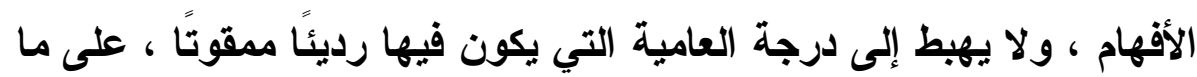

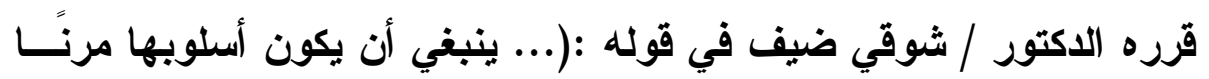

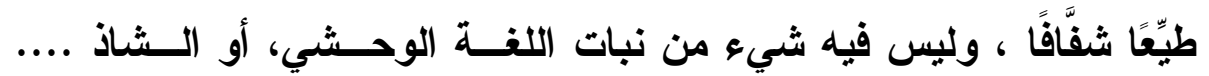

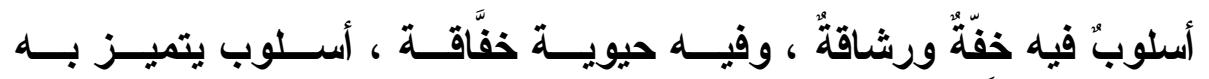
القصَّاصون،كما يتميز الموسيقيون بألحانهم..)(ب (r) .

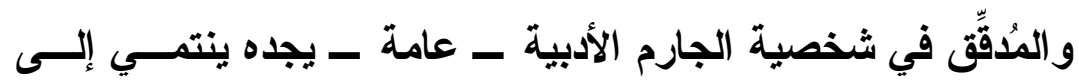

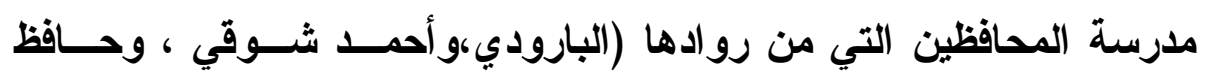

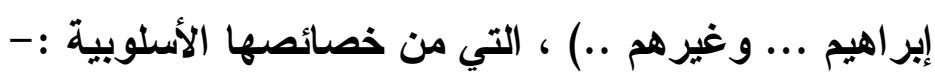

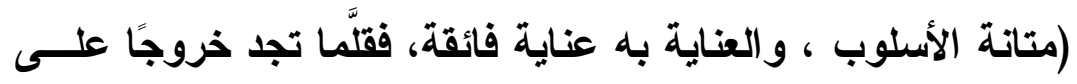

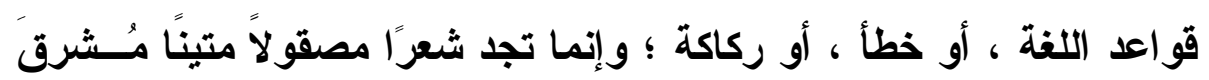

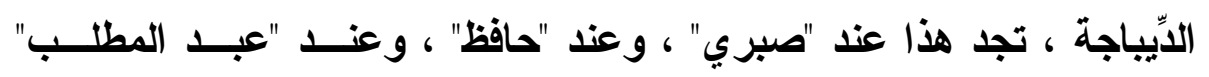

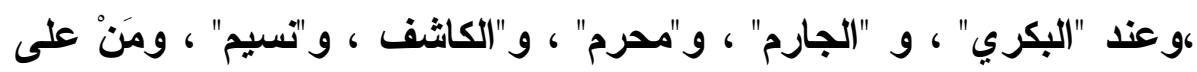

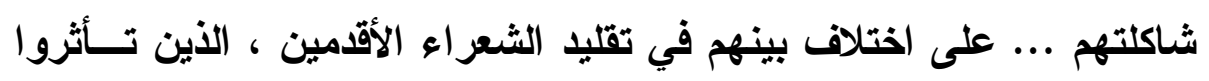

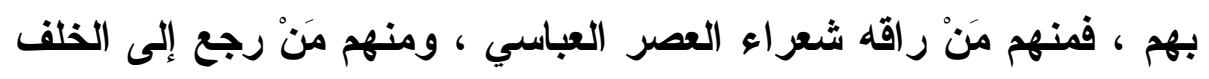

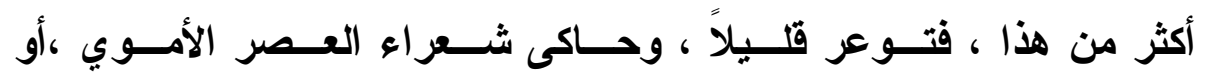

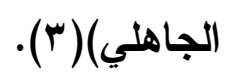

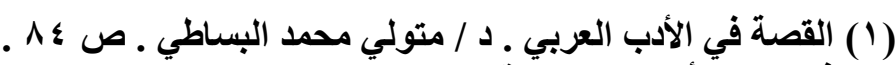

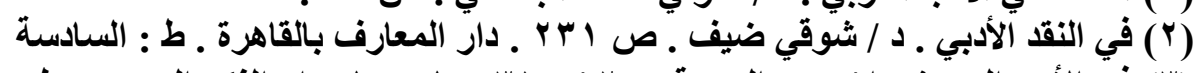

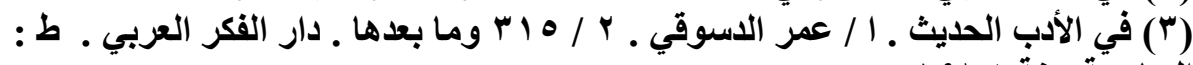


لذلك فإن أسلوب الجارم في المنـــى القصــصي يتـــف بــالقوة

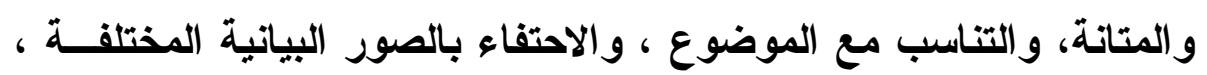

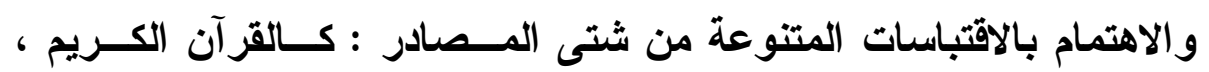

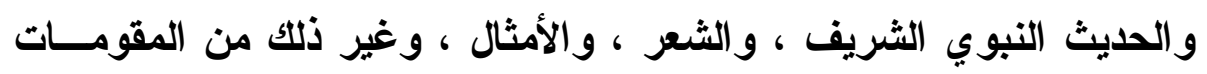
الفنية الأسلوبية التي اتسم بها المحافظون في نتاجهم الأدبي. مما يوحي بأنه ينتمي إلى مدرسة البيان في النثر العربي الحديث ،

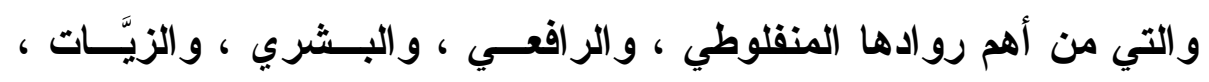

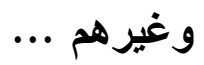

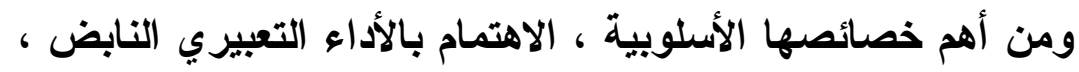
القائم على القواعد الصحيحة للتعبير ، حتى تتحقق فيه قيم الجمال الفني .

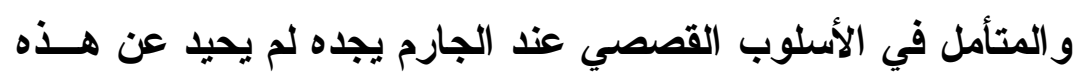

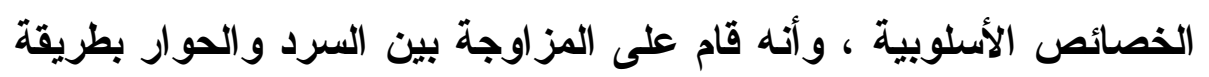

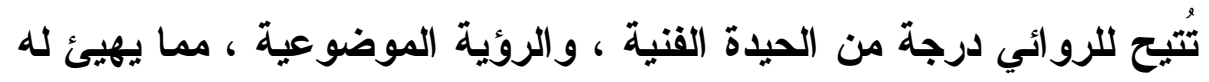

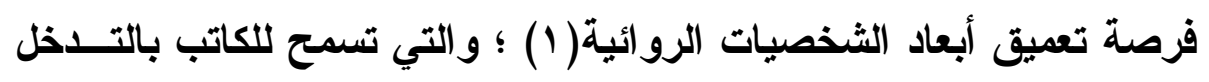

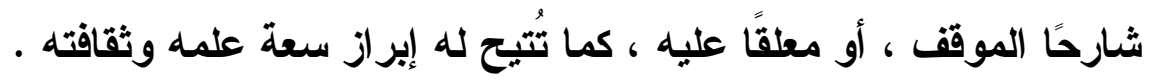

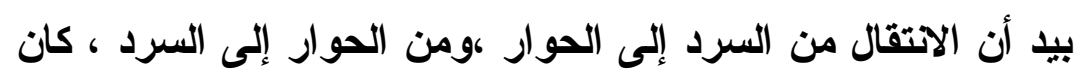

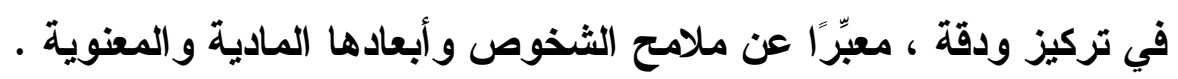

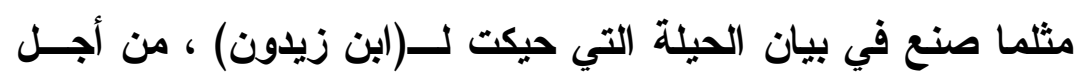

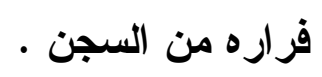

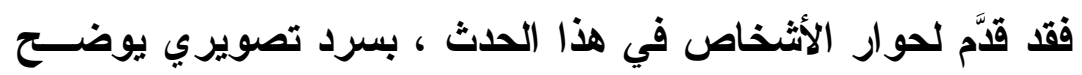

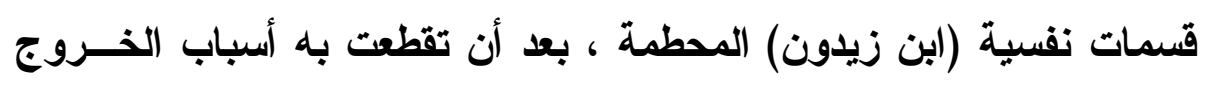

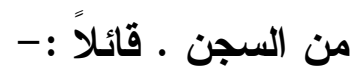

(1) نقد الرواية في الأدب العربي الحديث ـ د / أحمد الهواري ـ ص البr ـ دار المعارف

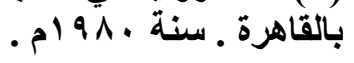




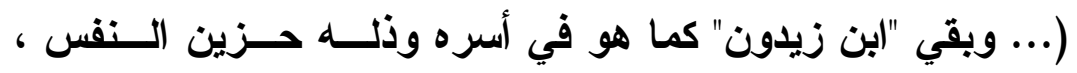
و واجف القلب ، بعد أن تقطعت به الأسباب ، وجفاه الصحاب ـ و وكانت "تائلة"

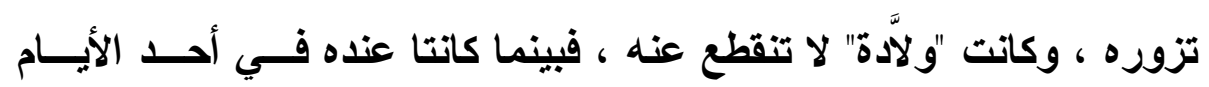

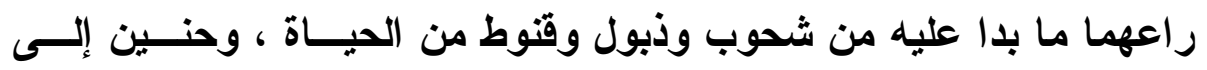
الموت ، وكان يقول ويُكرر : أما لهذا الليل مـن آخــر ؟ أمـــا آن للطــائر

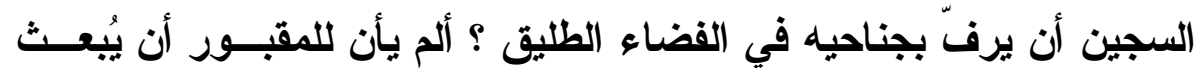

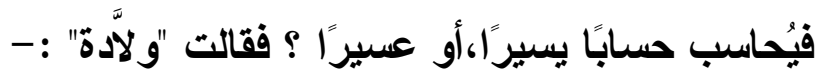

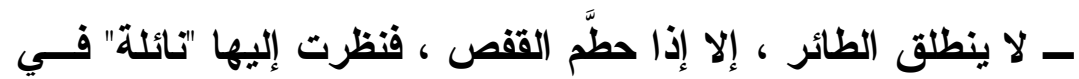

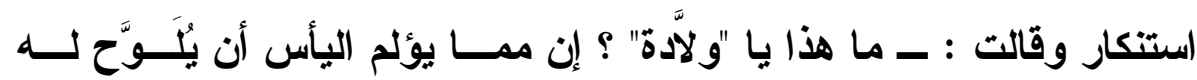

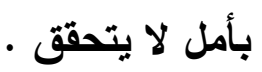

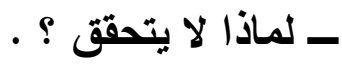

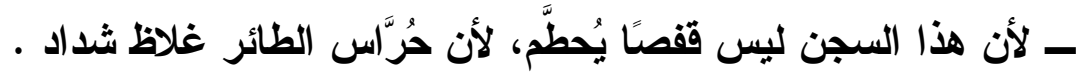
ـ إن من الحيلة ما يُعجز القوة ـ فعجل "ابن زيدون" ، وقال :-

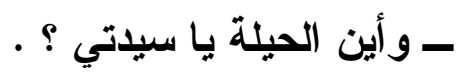

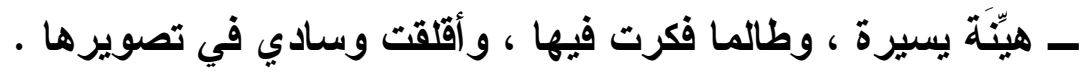

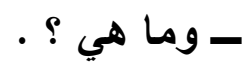

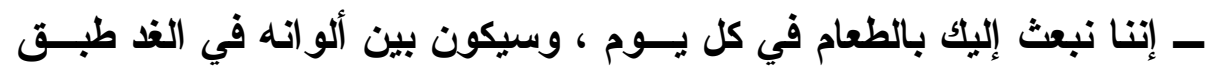

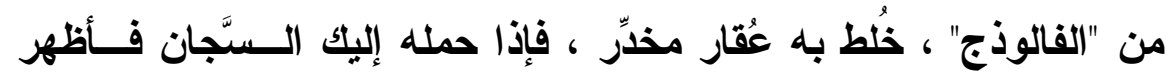

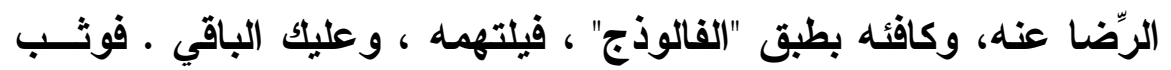

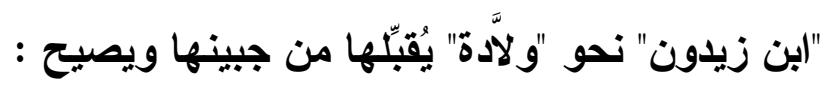

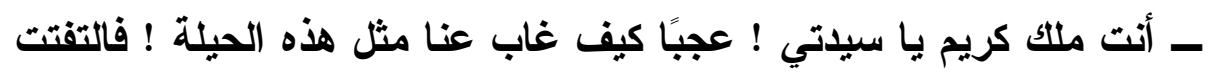

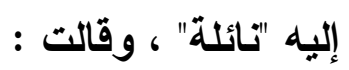




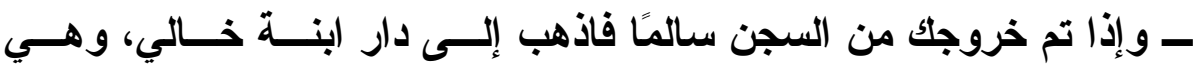
مصاقبة(1) لدار "ابن الحناط" الكفيف ، فاختف عندها ، حتى ندبر وسيلة

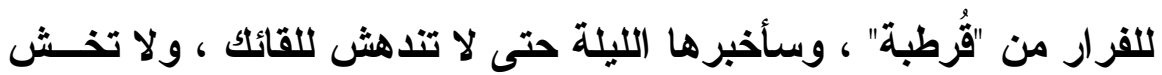

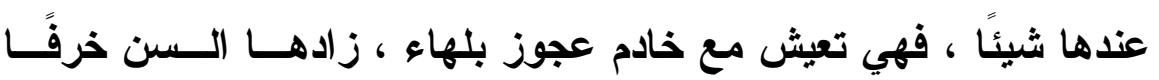

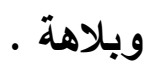

وبعد أن طال الحديث في الفرار وعو اقبه ، وفي تقصي كل ما يزيل

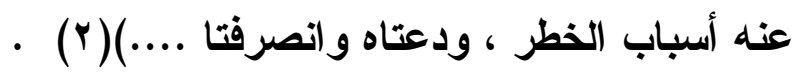

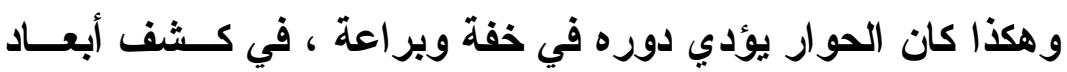

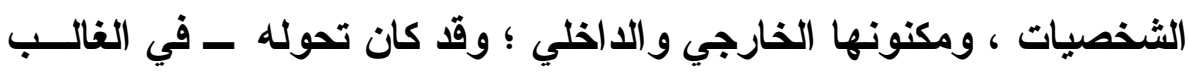

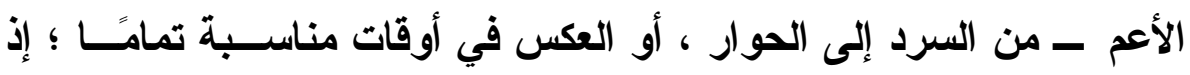

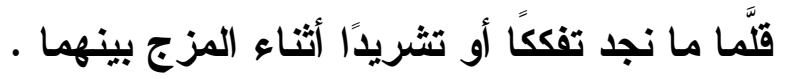
وقد اعتمد الجارم في أسلوبه هذا على المحاور الآتية :- 1

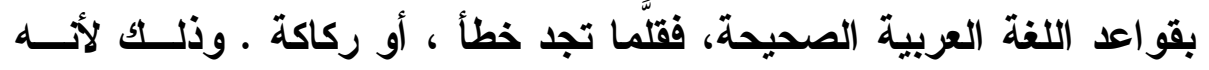

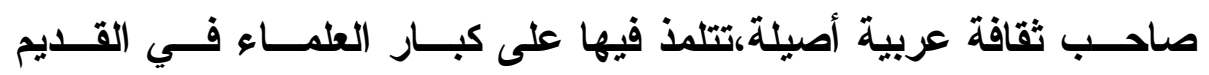
و الحديث ـ ولأن هذف صياغة هذه القصص التاريخية كان تعليميًا توجيهيًّـا

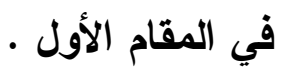
r - اعتمد على أسلوب الإيجاز والاختصار في عرض الأحداث التاريخية

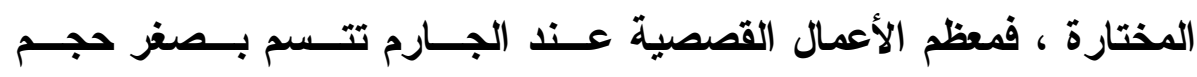

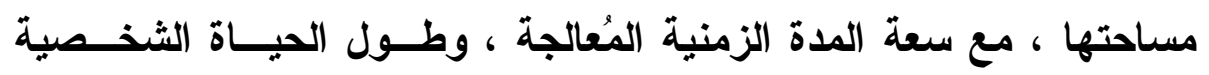

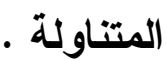


فالحدث الارامي التاريخي الكبير الذي يحتاج إلى مسساحة كبيـرة

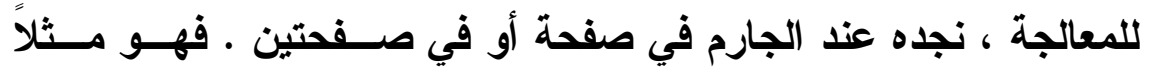

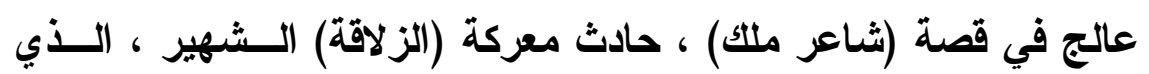

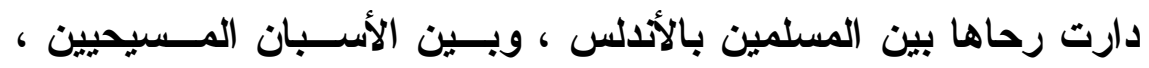

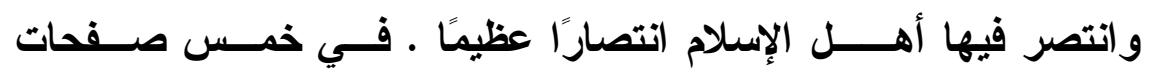
فقط (1) ، رغم أن هذا الحدث يحتاج إلى مساحات أكبر .

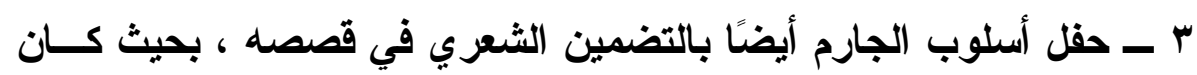

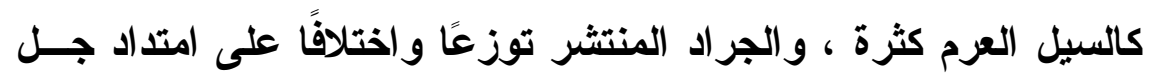

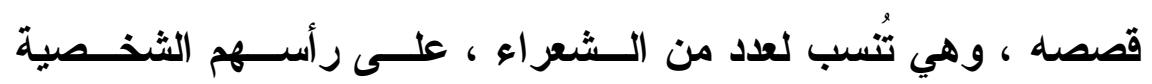

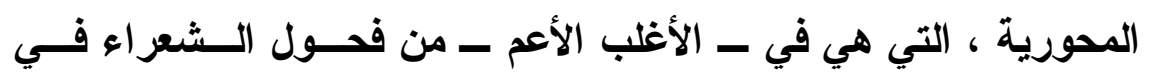

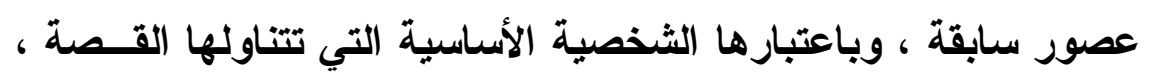

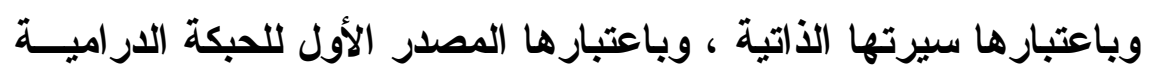

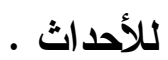

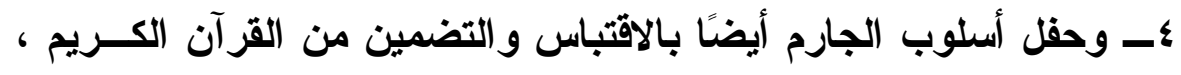

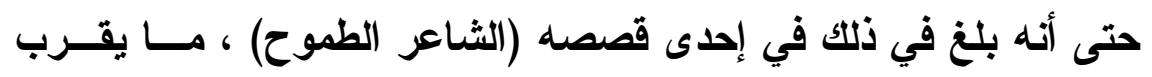

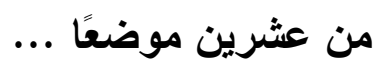

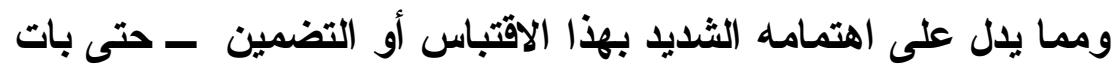
ظاهرة عنده - - هذا السرد التصويري على لسان أحد الثخوص حاكيًّا

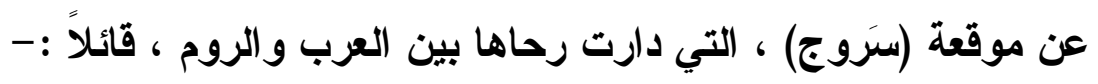

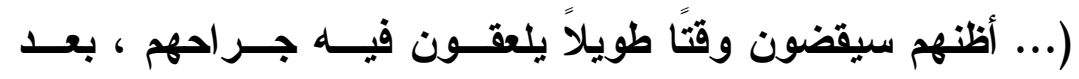

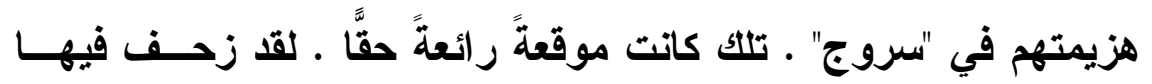

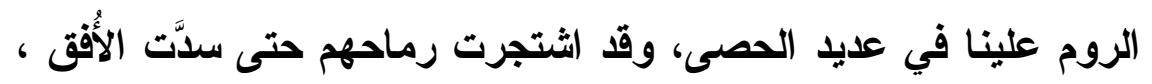

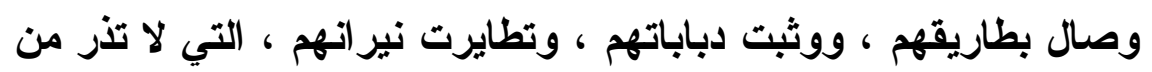




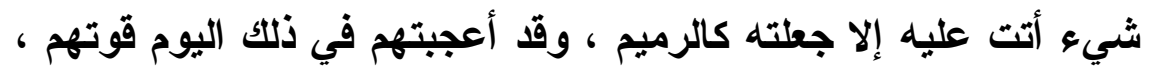

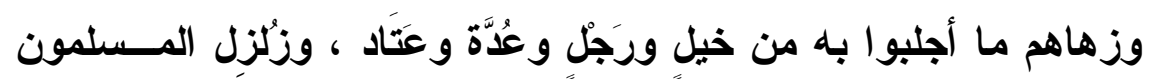

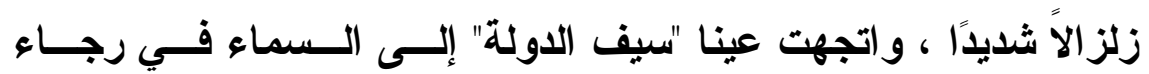

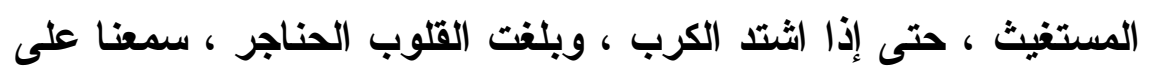

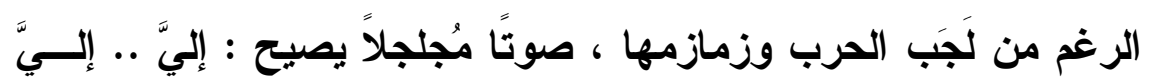

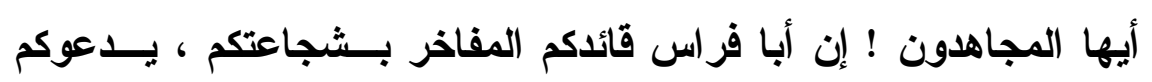

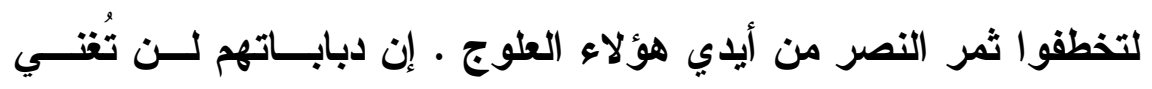

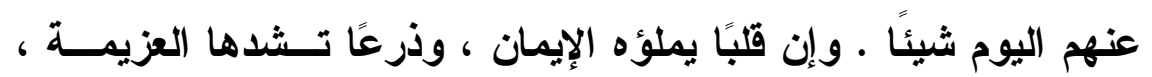

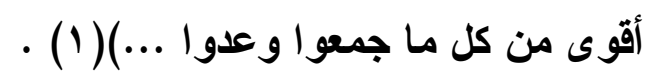

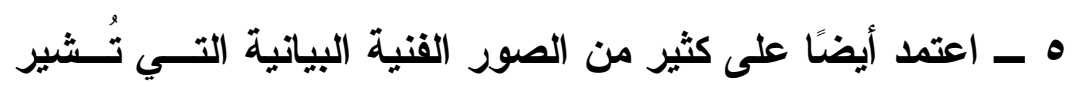

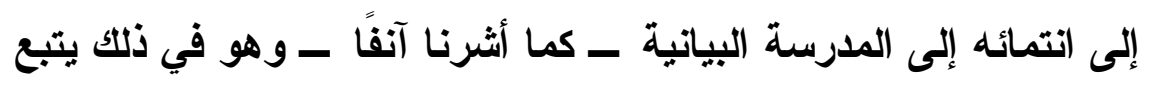

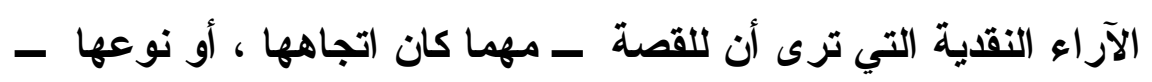

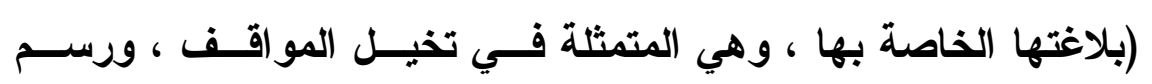

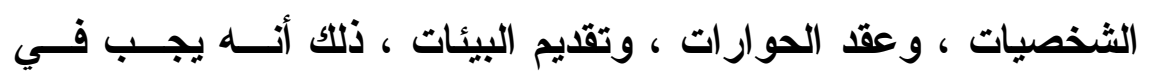

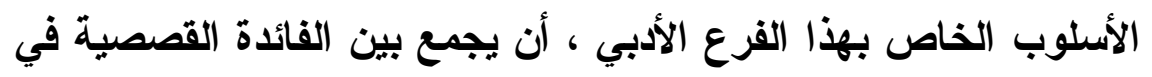

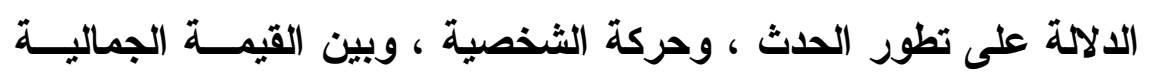

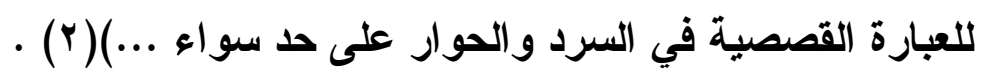

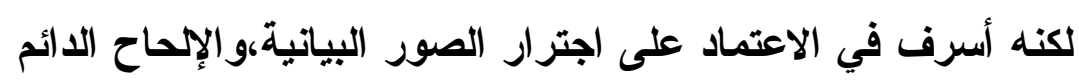

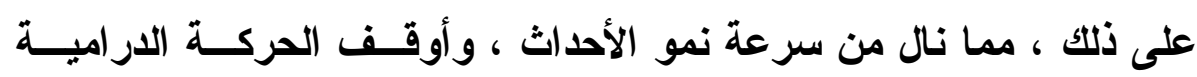
المتطورة . 
فما (نلح عليه بإصرار هو أن القصة نوع أدبي بالدرجة الأولـى ،

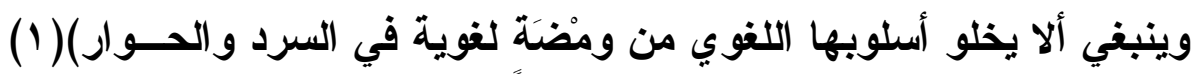

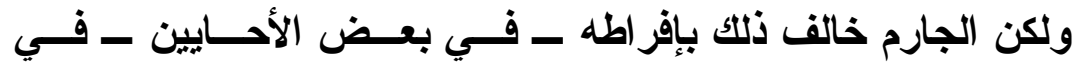

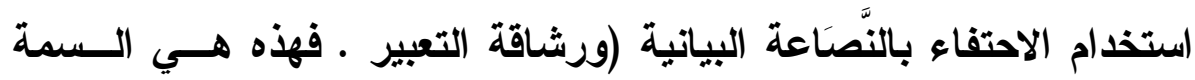

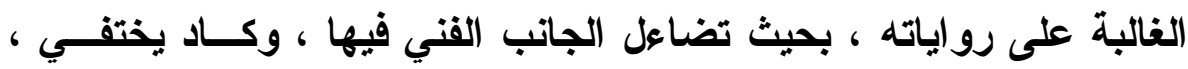

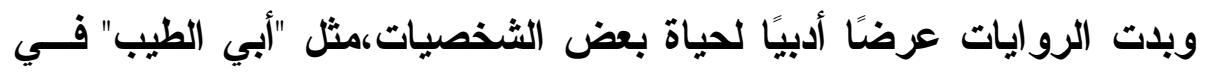

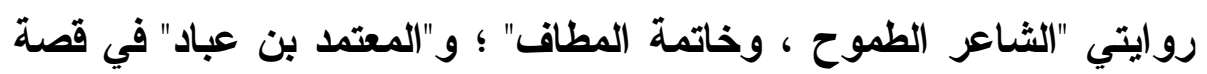

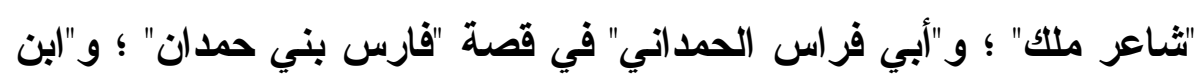

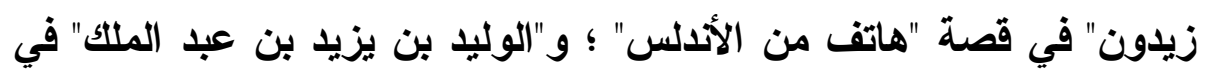

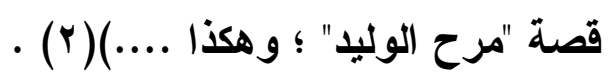

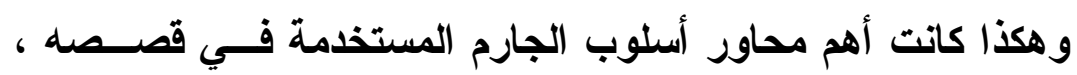

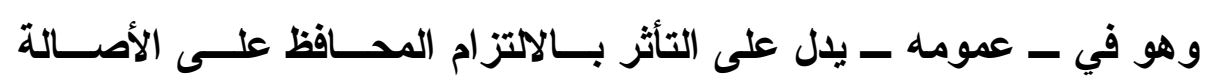
العربية في الأسلوب ، وما يحتويه من سمات وخصائص فنية . *** $*$ * $* * * *$ * $* * *$

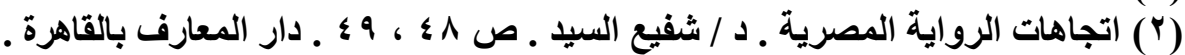

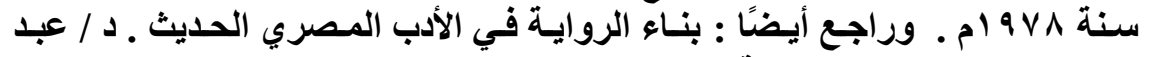

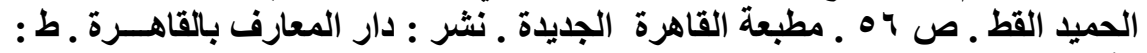




\section{ثبت المسادر والمراجع}

- إبراهيم عبد القادر المازني ـ د / نعمات فؤاد ـ الهيئة المصرية العامة

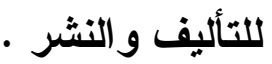

r ـ اتجاهات الرواية المصرية ـ د / شفيع السيد ـ دار المعارف بالقاهرة .

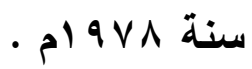

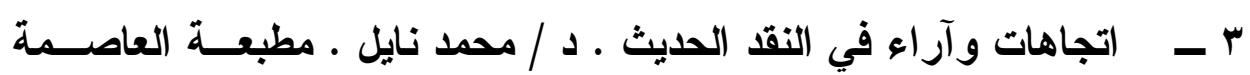

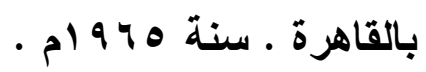

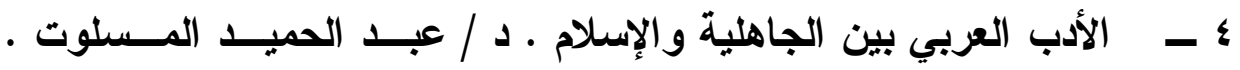

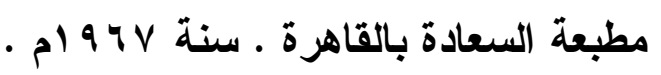

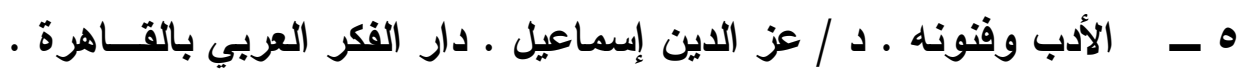

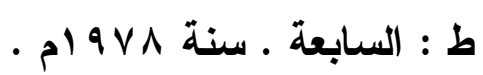

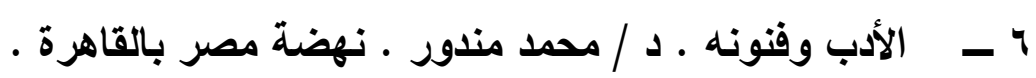

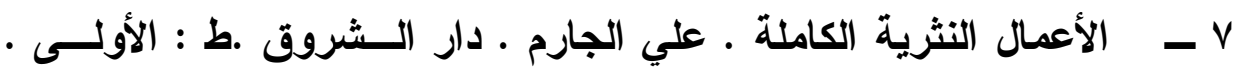

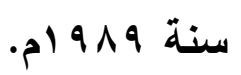

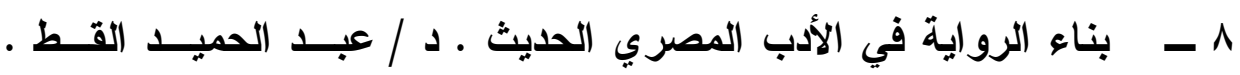

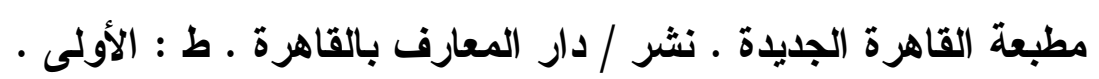

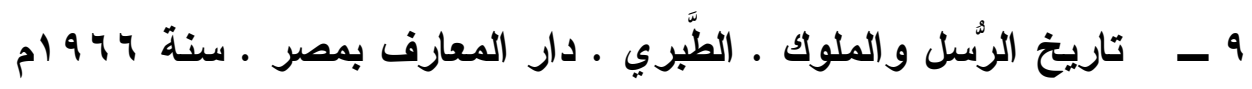

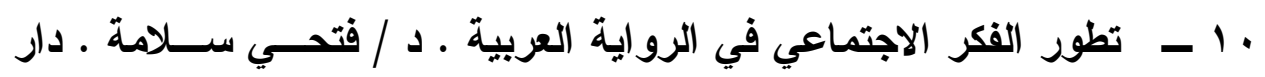

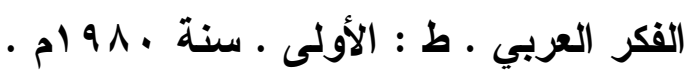

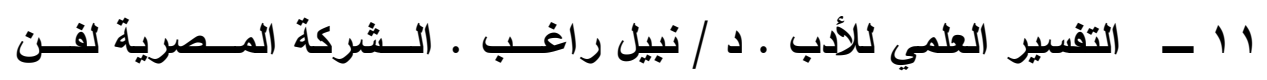

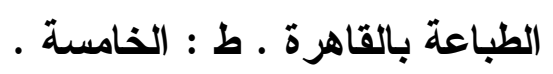

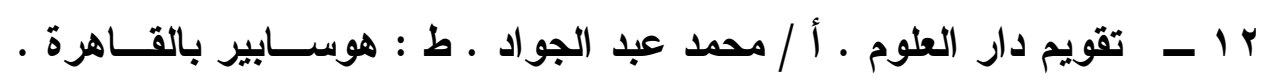

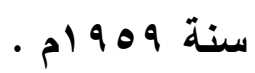


با - ـ الجارم الثاعر (عصره ، وحياته ، وشـعره) ـ أ / أحمــ الـشايب .

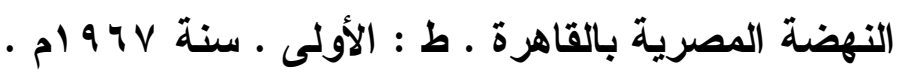

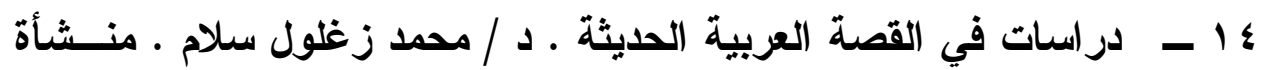

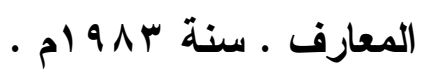

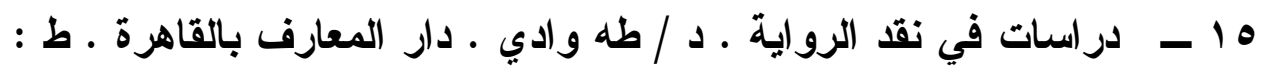

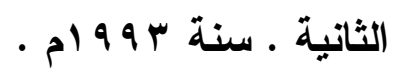

17 ـ ـ ديوان علي الجارم ـ علي الجارم ـ دار الشروق ـ ط : الثانية ـ ســنة

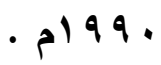

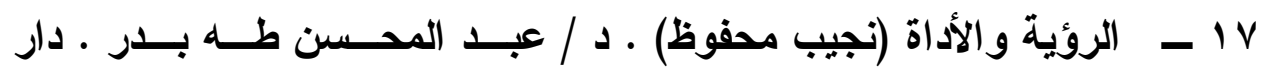

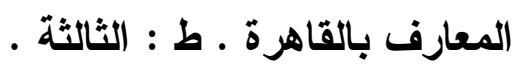

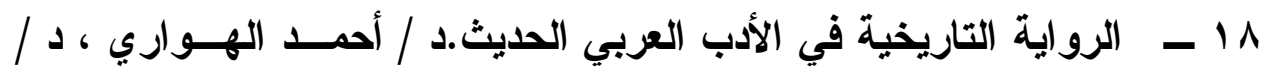

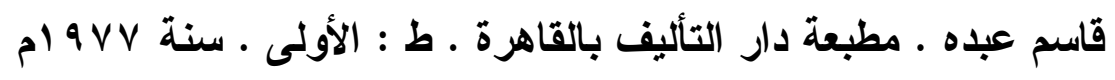

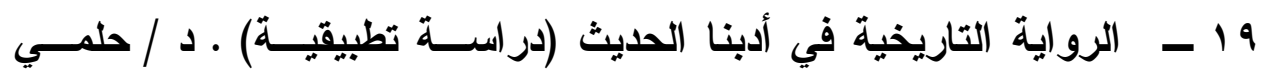

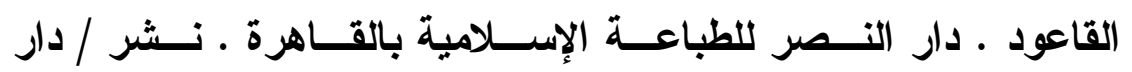

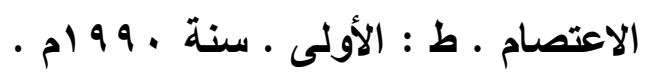

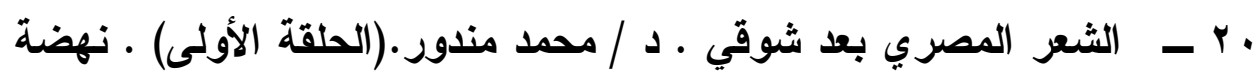

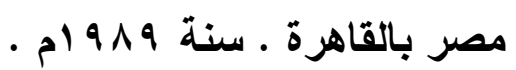

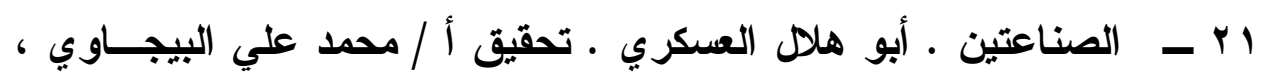

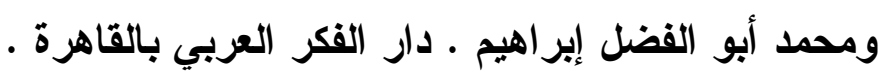

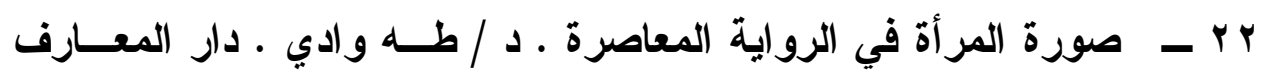

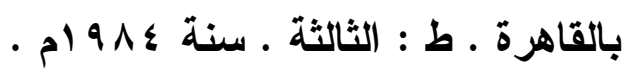

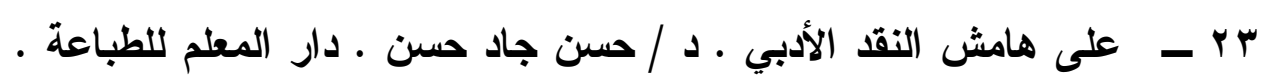

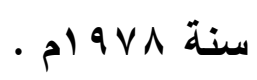

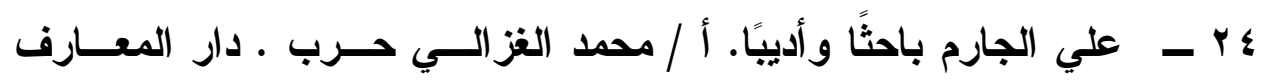
$-r+1-$ 


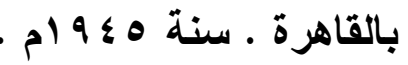

ه _ - الفن القصصي في الأدب العربي الحديث ـ ـ ـ محمود حامد شــوكت .

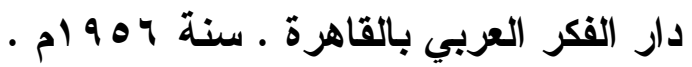

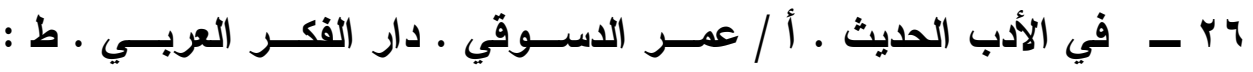

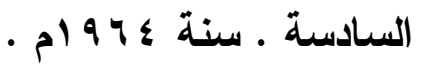

_ - rV

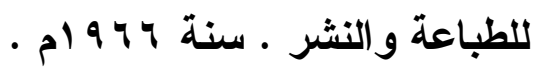

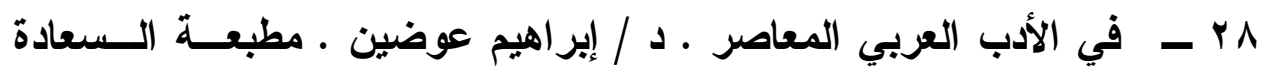

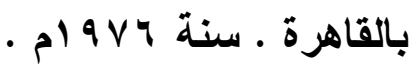

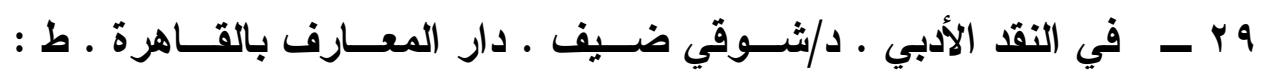
السادسة .

• ـ ـ القصة في الأدب العربي • د / متولي محمد البساطي ـ مطبعة السعادة

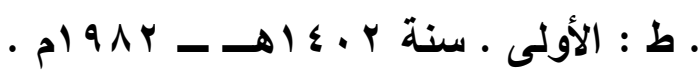

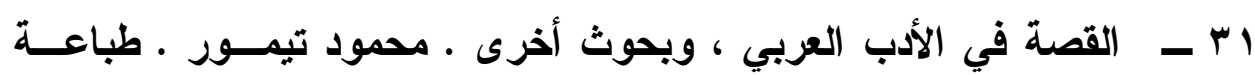

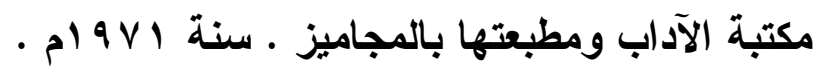

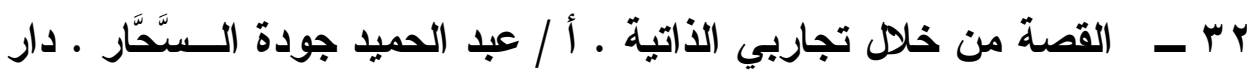
مصر للطباعة بالقاهرة .

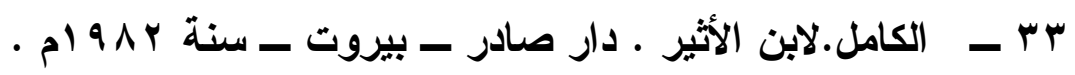

ع ا _ كتب وشخصيات ـ سيد قطب ـ دار الثروق ـ ط : الثالثة .

هr - مجمع اللغة العربية ـ ــ / عبد المنعم الاســوقي الجميعـي ـ الهيئـة

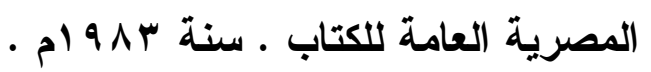

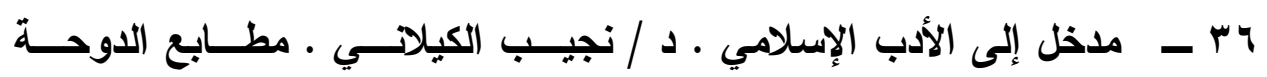

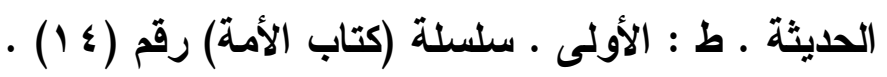




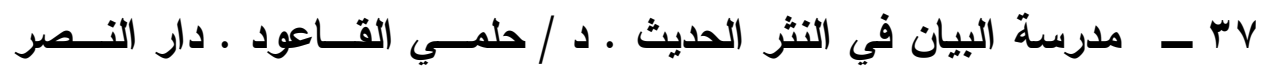
للطباعة الإسلامية ـ نثر دار الاعتصام بالقاهرة .

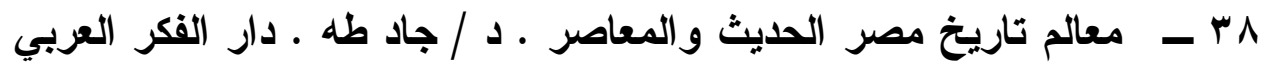

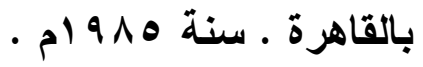

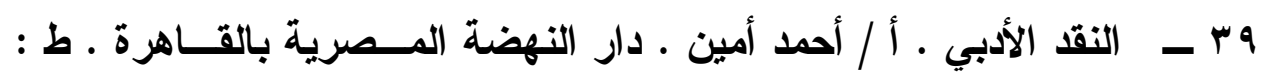

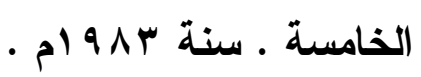

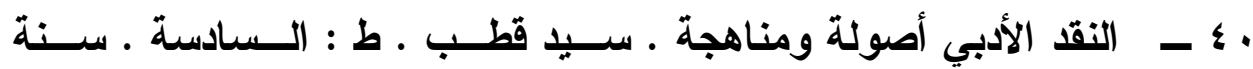
.

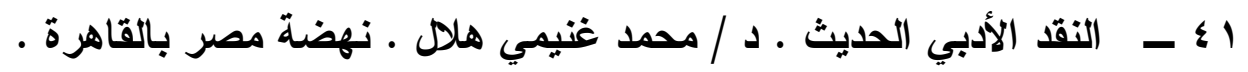

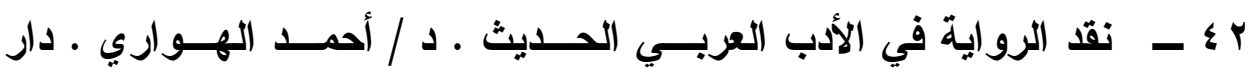

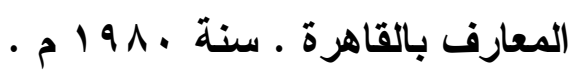

*** * $\quad$ **** * * * * * * * 
- rr. E - 